
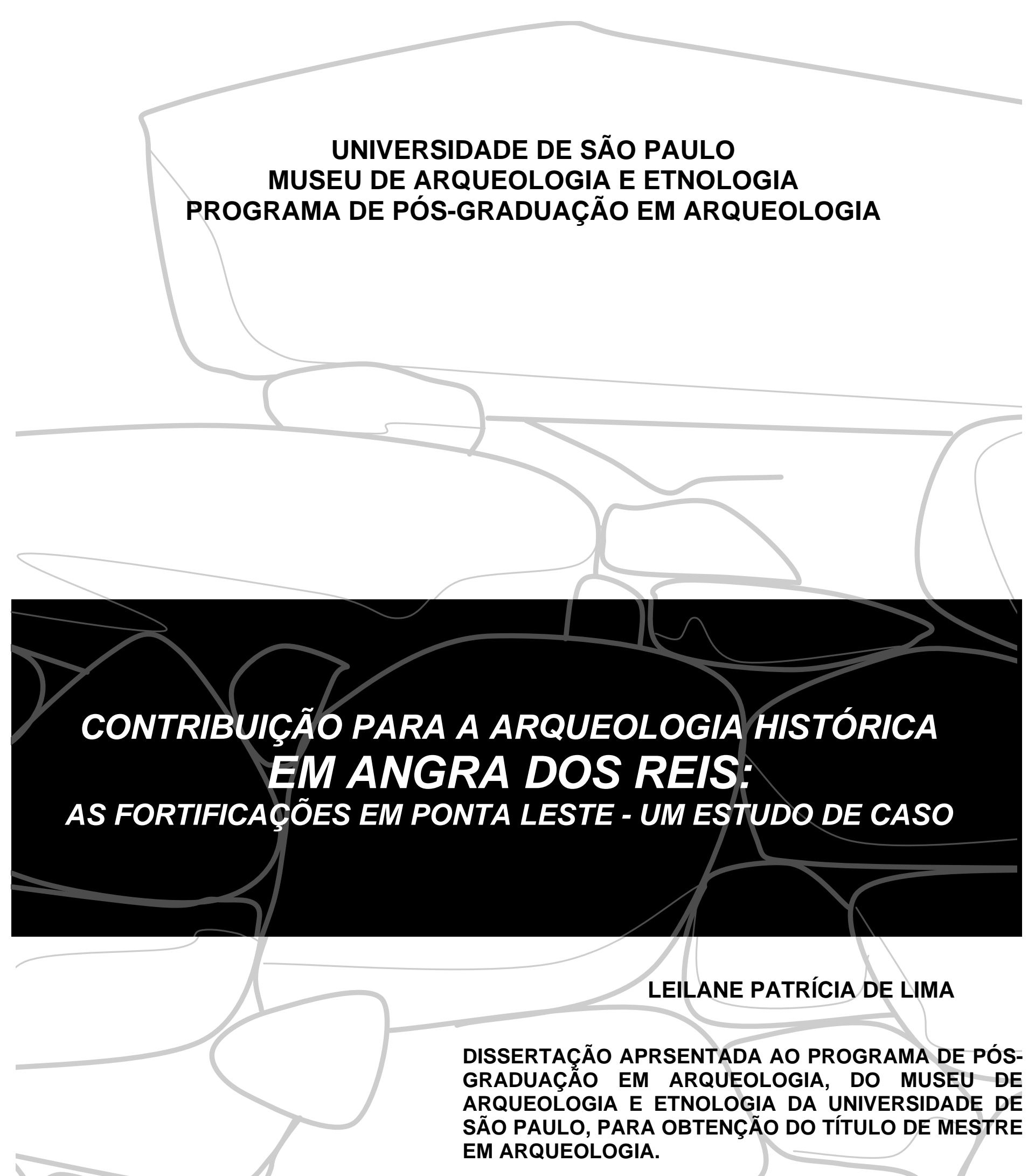

ORIENTADOR: PROF. DR. PEDRO PAULO ABREU FUNARI

LINHA DE PESQUISA: ARTEFATOS E CULTURA MATERIAL - SIGNIFICADOS E POTENCIALIDADES 


\author{
UNIVERSIDADE DE SÃO PAULO \\ MUSEU DE ARQUEOLOGIA E ETNOLOGIA \\ PROGRAMA DE PÓS-GRADUAÇÃO EM ARQUEOLOGIA
}

\title{
CONTRIBUIÇÃO PARA A ARQUEOLOGIA HISTÓRICA em Angra dos Reis: AS FORTIFICAÇÕES EM PONTA LESTE - UM ESTUDO DE CASO
}

Leilane Patrícia de Lima

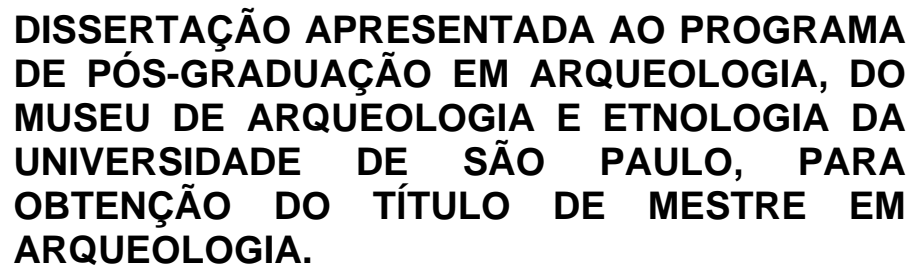

Orientador: Professor Dr. Pedro Paulo Abreu Funari

São Paulo

2008 
Aos meus pais, Manuel e Elenita, os grandes exemplos e amores da minha vida. 


\section{Agradecimentos}

Agradeço, em primeiro lugar, ao professor Dr. Pedro Paulo Abreu Funari e à professora Dra. Nanci Vieira de Oliveira, pela orientação e constante ajuda nos anos de desenvolvimento desta pesquisa. Outros docentes fundamentais na confecção deste trabalho e que merecem especial agradecimento são: professora Dra. Maria Cristina Oliveira Bruno, professora Dra. Erika RobrahnGonzález, professor Dr. Paulo Antônio De Blasis, professor Dr. José Luiz de Morais e professor Ms. Claudiomar dos Reis Gonçalves (in memorian).

Aos amigos queridos, meu enorme agradecimento pelos anos de amizade e incentivo tão preciosos. Assim, meu obrigada a: Keyla, Isadora, Alisson, Cássia, Paloma, Carlinha e Regina Alegro (grande conselheira para esta mestranda!). Aos meus tios amados: Eunia, Mário, Lula, Marinete, Nenê, Dora, Jaime e todos os outros.

Aos amigos do MAE (Eleuza e demais funcionários do Museu), Gilberto, Camila Zanon, Tatiana Bina, Mírian Pacheco, Rodolfo Luz e todos os outros colegas que fiz durante a pós-graduação, especialmente aos amigos cariocas: Ivan Francisco, Guilherme, Fábio, Flávia, Renata, Sueli, Carolina etc. Agradeço também às instituições de pesquisa: Universidade Estadual de Londrina, Universidade do Estado do Rio de Janeiro e Universidade de São Paulo.

Meu obrigada a toda equipe da DOCUMENTO Patrimônio Cultural, Arqueologia e Antropologia S/S Ltda. e à Secretaria da Educação do Estado de São Paulo pelo apoio operacional a minha pesquisa.

Por fim, meus agradecimentos às pessoas que fazem com que todo 0 esforço e dedicação do dia-a-dia tenham sentido. Meu obrigada ao meu pai, Manuel, minha mãe, Elenita, minha irmã, Luciana, meu companheiro Márcio, minha querida sogra Cida e cunhada Patrícia. Agradeço a vocês pelas orações, pela torcida, pela paciência e, pelo mais importante, o amor. Obrigada! 


\section{Resumo}

Esta pesquisa em Arqueologia Histórica tem como finalidade contribuir para a compreensão das estratégias de defesa implantadas durante o período colonial no litoral sul fluminense, a fim de protegê-lo da ameaça de invasão estrangeira e do contrabando de ouro e de escravos, através da construção de fortificações e locais de observação em vários pontos dessa região. O trabalho em Ponta Leste é uma extensão da análise da distribuição espacial de fortificações realizada em Piraquara, uma enseada próxima à Angra dos Reis, por meio do Projeto: "Área Arqueológica de Piraquara, Angra dos Reis", apoiado pela UERJ e financiado pela Eletronuclear, sob coordenação da arqueóloga Nanci Vieira de Oliveira. Nas etapas de campo em Ponta Leste foram identificadas estruturas defensivas semelhantes às que foram encontradas em Piraquara. Em ambos os casos, as baterias de pedra, armadas com canhões, tinham como função dificultar o desembarque e permitir à Vila de Angra dos Reis o tempo necessário para organizar sua defesa, em caso de ataque estrangeiro. Em Ponta Leste, além das pequenas estruturas defensivas, foi analisado o Forte do Leme, construído no início do século XX, com o objetivo de proteger a Baía da Ilha Grande.

Palavras-chave: Arqueologia Histórica, Contexto, Ponta Leste, Angra dos Reis, Estratégias defensivas, Fortificações. 


\begin{abstract}
This research in Historical Archaeology aims to add to the comprehension of the defensive strategies employed during the Colonial Era on Fluminense south coast. In order to protect it from the foreign invasion threat and from the gold and slaves smugglings, fortifications and observing places were built at many points in that region. The work in Ponta Leste is an extension of the analysis of fortifications distribution in Piraquara, a cove near Angra dos Reis, through the research project: "Piraquara Archaeological Area, Angra dos Reis", supported by UERJ and financed by Eletronuclear, under the coordination of the archaeologist Nanci Vieira de Oliveira. During the field work in Ponta Leste, defensive structures very similar to the ones found in Piraquara were identified. In both cases, the stone batteries, armed with cannons, had the function to make landing difficult and to give to Vila de Angra dos Reis the time needed to organize its defensive system in the case of foreign attack. In Ponta Leste, besides small defensive structures, Forte do Leme has been analysed, which was built in the beginning of $20^{\text {th }}$ century to protect Baía da Ilha Grande.
\end{abstract}

Keywords: Historical Archaeology, Context, Ponta Leste, Angra dos Reis, Defensive Strategies, Fortifications. 
Índice

Lista de figuras $\quad$ vii

$\begin{array}{ll}\text { Introdução } & \text { p. } 01\end{array}$

Capítulo I - Aspectos teóricos da Arqueologia Histórica e suas aplicações em estudos estratégicos

$\begin{array}{ll}\text { A Arqueologia Histórica e suas discussões } & \text { p. } 09\end{array}$

$\begin{array}{ll}\text { Perspectivas da Arqueologia Histórica no Brasil } & \text { p. } 13\end{array}$

Documento escrito e documento material: o diálogo entre as fontes p. 21

$\begin{array}{ll}\text { Defesa e estratégia na costa sul do litoral fluminense } & \text { p. } 28\end{array}$

Capítulo II - Arqueologia do sistema defensivo de Angra dos Reis

Aspectos econômicos de Angra dos Reis entre os séculos XVI e p. 35 $\mathrm{XIX}$

$\begin{array}{ll}\text { Projeto Área Arqueológica de Piraquara } & \text { p. } 41\end{array}$

As estratégias defensivas de Angra dos Reis: discussões $\quad$ p. 46 historiográficas e arqueológicas

$\begin{array}{ll}\text { A etapa de campo em Angra dos Reis } & \text { p. } 69\end{array}$

O Forte do Carmo e o "túnel" $\quad$ p. 69

$\begin{array}{ll}\text { Os canhões } & \text { p. } 72\end{array}$

Capítulo III - Arqueologia das estratégias defensivas na Ponta Leste

Referências documentais sobre as estratégias defensivas na Ponta p. 82 Leste

$\begin{array}{ll}\text { As etapas de campo em Ponta Leste } & \text { p. } 84\end{array}$ 
$\begin{array}{ll}\text { O Forte do Leme } & \text { p. } 85\end{array}$

$\begin{array}{ll}\text { Quartel p. } 85 & \text { p. }\end{array}$

$\begin{array}{ll}\text { Banheiro } & \text { p. } 87\end{array}$

$\begin{array}{ll}\text { Área cercada } & \text { p. } 87\end{array}$

$\begin{array}{ll}\text { Canhões } & \text { p. } 88\end{array}$

$\begin{array}{ll}\text { Casa do Comandante } & \text { p. } 89\end{array}$

Reflexões sobre a distribuição espacial do Forte do Leme p. 90

$\begin{array}{ll}\text { As estruturas defensivas de pedra seca } & \text { p. } 93\end{array}$

$\begin{array}{ll}\text { Estrutura } 1 & \text { p. } 93\end{array}$

$\begin{array}{ll}\text { Estrutura } 2 & \text { p. } 94\end{array}$

$\begin{array}{ll}\text { Estrutura } 4 & \text { p. } 95\end{array}$

$\begin{array}{ll}\text { As estruturas da Linha Férrea } & \text { p. } 96\end{array}$

$\begin{array}{ll}\text { Estrutura } 3 & \text { p. } 96\end{array}$

$\begin{array}{ll}\text { Estrutura Praia do Coqueiro } & \text { p. } 96\end{array}$

$\begin{array}{lr}\text { Estrutura de Monsuaba } & \text { p. } 97\end{array}$

Evidências defensivas na Ponta Leste $\quad$ p. 99

$\begin{array}{lr}\text { Conclusão } & \text { p. } 102\end{array}$

Bibliografia

$\begin{array}{ll}\text { Fontes primárias } & \text { p. } 106\end{array}$

$\begin{array}{ll}\text { Fontes secundárias } & \text { p. } 113\end{array}$

Anexo 
Documentos sobre a presença de navios estrangeiros e a defesa da Vila de Angra dos Reis

Documentos sobre a Ilha Grande e a Vila de Nossa Senhora da Conceição de Angra dos Reis da Ilha Grande

Documentos sobre a Vila de Santos e São Vicente

Documentos sobre Caminhos

p. 142

Documentos sobre o Forte do Leme, Ponta Leste, Angra dos Reis 


\section{Lista de figuras}

\begin{tabular}{|c|c|c|}
\hline Página 1.1 & Descrição & Procedência \\
\hline Figura 1 & $\begin{array}{l}\text { Mapa histórico que indica a } \\
\text { Ponta Leste }\end{array}$ & $\begin{array}{l}\text { Carta corographica da capitania do Ryo } \\
\text { de Janeyro, capital dos estados do Brasil } \\
\text { Por Francisco João Roscio, 1777- } \\
\text { Cartografia ARC.012,04,006, Biblioteca } \\
\text { Nacional }\end{array}$ \\
\hline Figura 2 & $\begin{array}{c}\text { Mapa histórico que indica a } \\
\text { Ponta Leste }\end{array}$ & $\begin{array}{l}\text { Capitam general e Vice-Rey do Estado } \\
\text { do Brazil Leão, Manuel Vieira, 1767, } \\
\text { CAM.02,008 Cartografia Biblioteca } \\
\text { Nacional }\end{array}$ \\
\hline Página 1.2 & Descrição & Procedência \\
\hline Figura 3 & Carta IBGE 1974 & $\begin{array}{c}\text { Carta IBGE - SF-23-Z-C-II-2, retirada do } \\
\text { site: www.ibge.gov.br/lojavirtual }\end{array}$ \\
\hline Figura 4 & Ponta Leste & $\begin{array}{l}\text { Mapa de turismo que indica a região da } \\
\text { Ponta Leste, retirado do site: } \\
\text { www.pontaleste.com }\end{array}$ \\
\hline Página 40.1 & Descrição & Procedência \\
\hline Figura 5 & Enseada de Piraquara & $\begin{array}{l}\text { Acervo do projeto "Área Arqueológica de } \\
\text { Piraquara" }\end{array}$ \\
\hline Página 41.1 & Descrição & Procedência \\
\hline Figura 6 & $\begin{array}{c}\text { Projeto sítio-museu } \\
\text { (sambaqui) }\end{array}$ & Imagem de Nanci Vieira de Oliveira \\
\hline Figura 7 & $\begin{array}{l}\text { Projeto sítio-museu } \\
\text { (estruturas de pedra) }\end{array}$ & Imagem de Nanci Vieira de Oliveira \\
\hline Página 42.1 & Descrição & $\begin{array}{c}\text { Procedência } \\
\end{array}$ \\
\hline Figura 8 & $\begin{array}{l}\text { Muro de pedra próximo à } \\
\text { Marina }\end{array}$ & $\begin{array}{c}\text { Acervo do Projeto "Área Arqueológica de } \\
\text { Piraquara" }\end{array}$ \\
\hline Figura 9 & Limpeza do muro de pedra & $\begin{array}{c}\text { Acervo do Projeto "Área Arqueológica de } \\
\text { Piraquara" }\end{array}$ \\
\hline Página 43.1 & Descrição & Procedência \\
\hline Figura 10 & Base de pedra & $\begin{array}{l}\text { Acervo do Projeto "Área Arqueológica de } \\
\text { Piraquara" }\end{array}$ \\
\hline Figura 11 & Base de pedra retangular & $\begin{array}{l}\text { Acervo do Projeto "Área Arqueológica de } \\
\text { Piraquara" }\end{array}$ \\
\hline Página 44.1 & & Procedência \\
\hline Figura 12 & Alinhamento de pedra & $\begin{array}{l}\text { Acervo do Projeto "Área Arqueológica de } \\
\text { Piraquara" }\end{array}$ \\
\hline Figura 13 & Alinhamento de pedra & $\begin{array}{c}\text { Acervo do Projeto "Área Arqueológica de } \\
\text { Piraquara" }\end{array}$ \\
\hline Figura 14 & $\begin{array}{l}\text { Alinhamento do pedra } \\
\text { associado a matacão }\end{array}$ & $\begin{array}{l}\text { Acervo do Projeto "Área Arqueológica de } \\
\text { Piraquara" }\end{array}$ \\
\hline Página 45.1 & Descrição & Procedência \\
\hline Figura 15 & Piraquara e Ponta Leste & $\begin{array}{c}\text { Acervo do Projeto "Área Arqueológica de } \\
\text { Piraquara" }\end{array}$ \\
\hline Página 54.1 & Descrição & Procedência \\
\hline Figura 16 & $\begin{array}{l}\text { Mapa de Angra dos Reis em } \\
1894\end{array}$ & $\begin{array}{l}\text { Arquivo Nacional - F4/MAP } 266 \text { - Planta } \\
\text { Hidrográfica do Porto de Angra dos Reis. } \\
\text { Inspetoria do } 4^{\circ} \text { Distrito de Portos } \\
\text { Marítimos: levantada e desenhada pelos } \\
\text { engenheiros Sabino Pessoa, Emílio Lobo }\end{array}$ \\
\hline
\end{tabular}




\begin{tabular}{|c|c|c|}
\hline & & $\begin{array}{l}\text { e auxiliar Alfredo Luís Baptista - Escala } \\
1: 10,1894 \text {. }\end{array}$ \\
\hline Página 54.2 & Descrição & $\begin{array}{l}\text { Procedência } \\
\end{array}$ \\
\hline Figura 17 & $\begin{array}{l}\text { Mapa de Angra dos Reis, } \\
1917 \text { (J.C.Sarmento), } \\
\text { adaptado por Gilberto da } \\
\text { Silva Francisco (2007). }\end{array}$ & $\begin{array}{l}\text { ALVES FILHO, D. S. Angra dos Reis: } \\
\text { monumentos históricos entre a } \\
\text { indústria e o paraíso. Dissertação } \\
\text { (Mestrado em Planejamento Urbano e } \\
\text { Regional)-Universidade Federal do Rio } \\
\text { de Janeiro, Rio de Janeiro, } 2004, \text { p. } 118 \text {. }\end{array}$ \\
\hline Página 56.1 & Descrição & Procedência \\
\hline Figura 18 & $\begin{array}{l}\text { Planta do Monte do Carmo } \\
\text { na Villa de Angra dos Reis } \\
\text { da Ilha Grande. }\end{array}$ & $\begin{array}{l}\text { Arquivo Histórico do Exército - plantas } \\
05011659 \text { e } 0501885 \text { (Documentos } \\
\text { fotografados e adaptados por Rodolfo } \\
\text { Alves Luz e Gilberto da Silva Francisco, } \\
\text { 2007). }\end{array}$ \\
\hline Página 56.2 & Descrição & Procedência \\
\hline Figura 19 & $\begin{array}{l}\text { Extremidade Oriental da } \\
\text { cidade de Angra dos Reis } \\
\text { entre a Praia do Carmo e o } \\
\text { Campo da Chácara, } 1839 .\end{array}$ & $\begin{array}{l}\text { Mapa do Arquivo Histórico do Exército - } \\
\text { (Documento fotografado e adaptado por } \\
\text { Rodolfo Alves Luz e Gilberto da Silva } \\
\text { Francisco, 2007). }\end{array}$ \\
\hline Página 70.1 & Descrição & Procedência \\
\hline Figura 20 & $\begin{array}{l}\text { Placa que indica a Rua da } \\
\text { Fortaleza }\end{array}$ & Imagem da autora \\
\hline Figura 21 & $\begin{array}{c}\text { Estrutura de pedra seca } \\
\text { Morro da Fortaleza }\end{array}$ & Imagem da autora \\
\hline Página 70.2 & Descrição & Procedência \\
\hline Figura 22 & Bloco de cimento & Imagem da autora \\
\hline Figura 23 & $\begin{array}{l}\text { Pilastras, muro e capela - } \\
\text { parte da frente }\end{array}$ & Imagem da autora \\
\hline Página 70.3 & Descrição & Procedência \\
\hline Figura 24 & $\begin{array}{l}\text { Detalhes das pilastras e do } \\
\text { muro - parte de trás }\end{array}$ & Imagem da autora \\
\hline Figura 25 & Vista do Morro da Fortaleza & Imagem da autora \\
\hline Página 71.1 & Descrição & Procedência \\
\hline Figura 26 & $\begin{array}{l}\text { Entrada do suposto túnel da } \\
\text { Fortaleza }\end{array}$ & Imagem da autora \\
\hline Figura 27 & Frente do "túnel" & Imagem da autora \\
\hline Página 71.2 & Descrição & Procedência \\
\hline Figura 28 & Interior do "túnel" & Imagem da autora \\
\hline Figura 29 & $\begin{array}{l}\text { Detalhe dos tijolos no interior } \\
\text { do "túnel" }\end{array}$ & Imagem da autora \\
\hline Página 71.3 & Descrição & Procedência \\
\hline Figura 30 & $\begin{array}{l}\text { Imagem de satélite Morro da } \\
\text { Fortaleza e túnel }\end{array}$ & $\begin{array}{c}\text { Tratada por Ivan Francisco (2008), } \\
\text { Laboratório de Antropologia Biológica da } \\
\text { UERJ }\end{array}$ \\
\hline Página 73.1 & Descrição & Procedência \\
\hline Figura 31 & Detalhes canhão & $\begin{array}{l}\text { CAMARGO, P. B. Arqueologia das } \\
\text { Fortificações Oitocentistas da Planície } \\
\text { Costeira Cananéia/Iguape. Dissertação } \\
\text { (Mestrado em Arqueologia), Museu de } \\
\text { Arqueologia e Etnologia, Universidade de } \\
\text { São Paulo, São Paulo, 2002, p. } 51 \text {. }\end{array}$ \\
\hline Página 74.1 & Descrição & Procedência \\
\hline
\end{tabular}




\begin{tabular}{|c|c|c|}
\hline Figura 32 & $\begin{array}{c}\text { Canhões da praça central de } \\
\text { Angra dos Reis }\end{array}$ & Imagem da autora \\
\hline Figura 33 & $\begin{array}{c}\text { Canhões Colégio Naval de } \\
\text { Angra dos Reis }\end{array}$ & Imagem da autora \\
\hline Página 75.1 & Descrição & Procedência \\
\hline Figura 34 & Perfil canhão 1 - Armstrong & Imagem da autora \\
\hline Figura 35 & SOLID na moldura da culatra & Imagem da autora \\
\hline Figura 36 & $\begin{array}{l}\text { Seqüência gravada no } 1^{\circ} \\
\text { reforço }\end{array}$ & Imagem da autora \\
\hline Figura 37 & Brasão 3 GR e duas setas & Imagem da autora \\
\hline Figura 38 & Terceira seta & Imagem da autora \\
\hline Figura 39 & Munhão direito canhão 4 & Imagem da autora \\
\hline Página 76.1 & Descrição & Procedência \\
\hline Figura 40 & $\begin{array}{l}\text { Número } 24 \text { no munhão } \\
\text { esquerdo }\end{array}$ & Imagem da autora \\
\hline Figura 41 & $\begin{array}{c}\text { Seqüência numérica do } \\
\text { canhão } 4\end{array}$ & Imagem da autora \\
\hline Figura 42 & $\begin{array}{c}\text { Brasão, seta e no } 11 \text { (canhão } \\
4 \text { ) }\end{array}$ & Imagem da autora \\
\hline Figura 43 & $\begin{array}{c}\text { Brasão } 3 \text { GR e inscrição WP } \\
\text { canhão } 5 \text { - Colégio Naval }\end{array}$ & Imagem da autora \\
\hline Figura 44 & Perfil canhão 2 & Imagem da autora \\
\hline Figura 45 & Rosa Tudor - canhão 2 & Imagem da autora \\
\hline Página 77.1 & Descrição & Procedência \\
\hline Figura 46 & Munhão direito canhão 2 & Imagem da autora \\
\hline Figura 47 & Inscrição numérica canhão 2 & Imagem da autora \\
\hline Figura 48 & Perfil canhão 3 & Imagem da autora \\
\hline Figura 49 & $\begin{array}{l}\text { Inscrição em números } \\
\text { romanos canhão } 3\end{array}$ & Imagem da autora \\
\hline Figura 50 & Perfil canhão 6 & Imagem da autora \\
\hline Figura 51 & $\begin{array}{c}\text { Brasão canhão } 6 \text { Colégio } \\
\text { Naval }\end{array}$ & Imagem da autora \\
\hline Página 83.1 & Descrição & Procedência \\
\hline Figura 52 & $\begin{array}{c}\text { Mapa da Baía da llha } \\
\text { Grande - as sondagens } \\
\text { indicam que a Ponta Leste } \\
\text { possui } 23 \text { braças de } \\
\text { profundidade } \\
\text { (aproximadamente } 44 \\
\text { metros) }\end{array}$ & $\begin{array}{l}\text { Arquivo Histórico do Exército - Mapa das } \\
\text { Baías de Ilha Grande e Sepetiba, s/d, } \\
\text { adaptado por Gilberto da Silva Francisco } \\
\text { (2007). }\end{array}$ \\
\hline Página 84.1 & Descrição & Procedência \\
\hline Figura 53 & $\begin{array}{l}\text { Ponta Leste - área de } \\
\text { inspeção visual }\end{array}$ & $\begin{array}{l}\text { Acervo do Projeto "Estratégias } \\
\text { ocupação e defesa do litoral sul } \\
\text { fluminense: uma análise da rede de } \\
\text { fortificacões na baia de llha Grande". }\end{array}$ \\
\hline Página 85.1 & Descrição & Procedência \\
\hline Figura 54a & $\begin{array}{l}\text { Esquema da situação das } \\
\text { edificações do Forte do } \\
\text { Leme }\end{array}$ & $\begin{array}{l}\text { Elaborado por Gilberto da Silva Francisco } \\
\qquad(2007)\end{array}$ \\
\hline Página 85.2 & Descrição & Procedência \\
\hline Figura 54b & $\begin{array}{l}\text { Imagem de satélite do Forte } \\
\text { do Leme }\end{array}$ & $\begin{array}{c}\text { Tratada por Ivan Francisco (2008), } \\
\text { Laboratório de Antropologia Biológica da } \\
\text { UERJ }\end{array}$ \\
\hline Página 85.3 & Descrição & Procedência \\
\hline
\end{tabular}




\begin{tabular}{|c|c|c|}
\hline Figura 55 & $\begin{array}{l}\text { Planta baixa do quartel do } \\
\text { Forte do Leme }\end{array}$ & $\begin{array}{l}\text { Elaborada por Gilberto da Silva Francisco } \\
\qquad(2007)\end{array}$ \\
\hline Figura 56 & $\begin{array}{l}\text { Alguns pisos identificados no } \\
\text { Forte do Leme }\end{array}$ & $\begin{array}{l}\text { Elaborado por Gilberto da Silva Francisco } \\
\qquad(2007)\end{array}$ \\
\hline Página 85.4 & Descrição & Procedência \\
\hline Figura 57 & $\begin{array}{l}\text { Detalhe da fachada do } \\
\text { quartel do Forte do Leme }\end{array}$ & Imagem da autora \\
\hline Figura 58 & Treliça de ferro do quartel & Imagem da autora \\
\hline Página 86.1 & Descrição & Procedência \\
\hline Figura 59 & $\begin{array}{l}\text { Porta larga e arco, à direita } \\
\text { do cômodo } n .^{\circ} 1\end{array}$ & Imagem da autora \\
\hline Figura 60 & $\begin{array}{l}\text { Parede (tijolo e pedra), } \\
\text { cômodo n. } 5\end{array}$ & Imagem da autora \\
\hline Figura 61 & Soleira do quartel & Imagem da autora \\
\hline Figura 62 & Latrina do banheiro & Imagem da autora \\
\hline Página 87.1 & Descrição & Procedência \\
\hline Figura 63 & $\begin{array}{l}\text { Planta baixa do banheiro e } \\
\text { foto da fachada }\end{array}$ & Imagem da autora \\
\hline Figura 64 & $\begin{array}{l}\text { Área cercada à retaguarda } \\
\text { do Forte do Leme }\end{array}$ & Imagem da autora \\
\hline Página 87.2 & Descrição & Procedência \\
\hline Figura 65 & $\begin{array}{c}\text { Muro com seteiras (em } \\
\text { detalhe o esquema da } \\
\text { seteira) }\end{array}$ & $\begin{array}{l}\text { Imagem da autora e esquema elaborado } \\
\text { por Gilberto da Silva Francisco (2007) }\end{array}$ \\
\hline Figura 66 & Acesso ao paiol e às galerias & Imagem da autora \\
\hline Página 87.3 & Descrição & Procedência \\
\hline Figura 67 & Paiol do Forte do Leme & Imagem da autora \\
\hline Figura 68 & $\begin{array}{l}\text { Galeria subterrânea do Forte } \\
\text { do Leme }\end{array}$ & Imagem da autora \\
\hline Página 88.1 & Descrição & Procedência \\
\hline Figura 69 & Bateria (fosso circular) & Imagem da autora \\
\hline Figura 70 & Canhão Forte do Leme & Imagem da autora \\
\hline Página 89.1 & Descrição & Procedência \\
\hline Figura 71 & $\begin{array}{l}\text { Planta baixa da Casa do } \\
\text { Comandante e foto da face } \\
\text { noroeste }\end{array}$ & $\begin{array}{l}\text { Planta elaborada por Gilberto da Silva } \\
\text { Francisco (2007) e imagem da autora }\end{array}$ \\
\hline Figura 72 & $\begin{array}{l}\text { Casa do Comandante - face } \\
\text { sul }\end{array}$ & Imagem da autora \\
\hline Página 90.1 & Descrição & Procedência \\
\hline Figura 73 & $\begin{array}{l}\text { Estrada de acesso ao Forte } \\
\text { do Leme }\end{array}$ & Imagem da autora \\
\hline Figura 74 & $\begin{array}{l}\text { Enseadas de acesso ao } \\
\text { Forte do Leme }\end{array}$ & $\begin{array}{l}\text { Acervo do Projeto "Estratégias } \\
\text { ocupação e defesa do litoral sul } \\
\text { fluminense: uma análise da rede de } \\
\text { fortificações na baia de llha Grande". }\end{array}$ \\
\hline Página 90.2 & Descrição & Procedência \\
\hline Figura 75 & $\begin{array}{l}\text { Trilha de acesso à Ponta do } \\
\text { Pasto }\end{array}$ & Imagem da autora \\
\hline Figura 76 & $\begin{array}{l}\text { Escada de acesso ao Píer } \\
\text { da Petrobrás }\end{array}$ & Imagem da autora \\
\hline Página 91.1 & Descrição & Procedência \\
\hline Figura 77 & $\begin{array}{l}\text { Trilha que liga o Forte do } \\
\text { Leme à praia das estruturas }\end{array}$ & Imagem da autora \\
\hline
\end{tabular}




\begin{tabular}{|c|c|c|}
\hline Figura 78 & $\begin{array}{l}\text { Acesso ao Forte do Leme } \\
\text { pela trilha leste }\end{array}$ & Imagem da autora \\
\hline Página 91.2 & Descrição & Procedência \\
\hline Figura 79 & Parte de trás do quartel & Imagem da autora \\
\hline Figura 80 & $\begin{array}{l}\text { Quartel com vista para a } \\
\text { retaguarda }\end{array}$ & Imagem da autora \\
\hline Página 93.1 & Descrição & Procedência \\
\hline Figura 81 & $\begin{array}{l}\text { Trilha para a praia onde se } \\
\text { encontram as estruturas }\end{array}$ & Imagem da autora \\
\hline Figura 82 & $\begin{array}{c}\text { Descaracterização da } \\
\text { estrutura } 1\end{array}$ & Imagem da autora \\
\hline Página 93.2 & Descrição & Procedência \\
\hline Figura 83 & $\begin{array}{c}\text { Sondagem na parte inferior - } \\
\text { face } 1 \text { - estrutura } 1\end{array}$ & Imagem da autora \\
\hline Figura 84 & $\begin{array}{l}\text { Sondagem na parte superior } \\
\text { - face } 1 \text { - estrutura } 1\end{array}$ & Imagem da autora \\
\hline Página 94.1 & Descrição & Procedência \\
\hline Figura 85 & $\begin{array}{l}\text { Sondagem na parte superior } \\
\text { - face } 2 \text { - estrutura } 1\end{array}$ & Imagem da autora \\
\hline Figura 86 & $\begin{array}{c}\text { Detalhe da face } 2 \text { - estrutura } \\
1 \text { - parte inferior }\end{array}$ & Imagem da autora \\
\hline Página 94.2 & Descrição & Procedência \\
\hline Figura 87 & $\begin{array}{c}\text { Esquema geral das } \\
\text { estruturas }(1 \text { e } 2) \text { e detalhes } \\
\text { das faces } 1 \text { e } 2 \text {, estrutura } 1 \text { e } \\
\text { face } 3 \text {, estrutura } 2\end{array}$ & $\begin{array}{l}\text { Elaborado por Gilberto da Silva Francisco } \\
\qquad(2007)\end{array}$ \\
\hline Página 94.3 & Descrição & Procedência \\
\hline Figura 88 & $\begin{array}{l}\text { Provável desmoronamento } \\
\text { estrutura } 1\end{array}$ & Imagem da autora \\
\hline Figura 89 & $\begin{array}{c}\text { Provável continuação } \\
\text { estrutura } 1\end{array}$ & Imagem da autora \\
\hline Figura 90 & $\begin{array}{c}\text { Bambuzal associado à } \\
\text { continuação da estrutura } 1\end{array}$ & Imagem da autora \\
\hline Página 94.4 & Descrição & Procedência \\
\hline Figura 91 & Estrutura 1 & $\begin{array}{c}\text { Tratada por Ivan Francisco (2008), } \\
\text { Laboratório de Antropologia Biológica da } \\
\text { UERJ }\end{array}$ \\
\hline Página 95.1 & Descrição & Procedência \\
\hline Figura 92 & $\begin{array}{l}\text { Sondagem na parte superior } \\
\text { - estrutura } 2\end{array}$ & Imagem da autora \\
\hline Figura 93 & $\begin{array}{c}\text { Pedra na parte inferior da } \\
\text { estrutura } 2 \text { - vestígios de } \\
\text { fogueira }\end{array}$ & Imagem da autora \\
\hline Página 95.2 & Descrição & Procedência \\
\hline Figura 94 & $\begin{array}{l}\text { Detalhe da face sondada, } \\
\text { estrutura } 2\end{array}$ & Imagem da autora \\
\hline Figura 95 & Estrutura 4 & Imagem da autora \\
\hline Página 95.3 & Descrição & Procedência \\
\hline Figura 96 & Estrutura 4 & Imagem da autora \\
\hline Figura 97 & $\begin{array}{l}\text { Lado da enseada, estrutura } \\
\qquad 4\end{array}$ & Imagem da autora \\
\hline Figura 98 & $\begin{array}{l}\text { Base em tijolos logo acima } \\
\text { da estrutura } 4\end{array}$ & Imagem da autora \\
\hline Página 95.4 & Descrição & Procedência \\
\hline
\end{tabular}




\begin{tabular}{|c|c|c|}
\hline Figura 99 & $\begin{array}{l}\text { Blocos de cimento logo } \\
\text { acima da estrutura } 4\end{array}$ & Imagem da autora \\
\hline Figura 100 & $\begin{array}{l}\text { Vista para as estruturas } 1 \text { e } \\
2 \text { e à direita ancoradouro }\end{array}$ & Imagem da autora \\
\hline Página 95.5 & Descrição & Procedência \\
\hline Figura 101 & Estrutura 2 & $\begin{array}{c}\text { Tratada por Ivan Francisco (2008), } \\
\text { Laboratório de Antropologia Biológica da } \\
\text { UERJ }\end{array}$ \\
\hline Página 95.6 & Descrição & Procedência \\
\hline Figura 102 & Estrutura 4 & $\begin{array}{c}\text { Tratada por Ivan Francisco (2008), } \\
\text { Laboratório de Antropologia Biológica da } \\
\text { UERJ }\end{array}$ \\
\hline Página 96.1 & Descrição & Procedência \\
\hline Figura 103 & Esquema da estrutura 3 & $\begin{array}{l}\text { Elaborado por Gilberto da Silva Francisco } \\
\qquad(2007)\end{array}$ \\
\hline Figura 104 & $\begin{array}{c}\text { Estrutura } 3.1 \text { - limpeza lado } \\
\text { externo }\end{array}$ & Imagem da autora \\
\hline Figura 105 & $\begin{array}{c}\text { Estrutura } 3.2 \text { - limpeza lado } \\
\text { externo }\end{array}$ & Imagem da autora \\
\hline Página 96.2 & Descrição & Procedência \\
\hline Figura 106 & Estrutura 3.1 e 3.2 & Imagem da autora \\
\hline Figura 107 & Detalhe da estrutura 3.1 & Imagem da autora \\
\hline Página 97.1 & Descrição & Procedência \\
\hline Figura 108 & $\begin{array}{l}\text { Imagem da internet que } \\
\text { indica estrutura da antiga } \\
\text { linha férrea }\end{array}$ & Retirada do site www.angra-dos-reis.com \\
\hline Figura 109 & $\begin{array}{l}\text { Situação atual da estrutura } \\
\text { Praia do Coqueiro }\end{array}$ & Imagem da autora \\
\hline Página 97.2 & Descrição & Procedência \\
\hline Figura 110 & $\begin{array}{c}\text { Galeria de acesso à } \\
\text { estrutura Praia do Coqueiro }\end{array}$ & Imagem da autora \\
\hline Figura 111 & $\begin{array}{l}\text { Detalhe da parte interna da } \\
\text { galeria }\end{array}$ & Imagem da autora \\
\hline Página 97.3 & Descrição & Procedência \\
\hline Figura 112 & $\begin{array}{l}\text { Estrutura de pedra cortada - } \\
\text { Cachoeira de Monsuaba }\end{array}$ & Imagem a autora \\
\hline Figura 113 & $\begin{array}{c}\text { Detalhe da estrutura de } \\
\text { Monsuaba }\end{array}$ & Imagem da autora \\
\hline Página 97.4 & Descrição & Procedência \\
\hline Figura 114 & $\begin{array}{l}\text { Parede da estrutura de } \\
\text { Monsuaba }\end{array}$ & Imagem da autora \\
\hline Figura 115 & Detalhe da casa e do riacho & Imagem da autora \\
\hline Página 97.5 & Descrição & Procedência \\
\hline Figura 116 & Estrutura 3 & $\begin{array}{c}\text { Tratada por Ivan Francisco (2008), } \\
\text { Laboratório de Antropologia Biológica da } \\
\text { UERJ }\end{array}$ \\
\hline Página 97.6 & Descrição & Procedência \\
\hline Figura 117 & Imagem Praia do Coqueiro & $\begin{array}{c}\text { Tratada por Ivan Francisco (2008), } \\
\text { Laboratório de Antropologia Biológica da } \\
\text { UERJ }\end{array}$ \\
\hline Página 97.7 & Descrição & Procedência \\
\hline Figura 118 & $\begin{array}{c}\text { Estrutura Cachoeira de } \\
\text { Monsuaba }\end{array}$ & $\begin{array}{c}\text { Tratada por Ivan Francisco (2008), } \\
\text { Laboratório de Antropologia Biológica da } \\
\text { UERJ }\end{array}$ \\
\hline
\end{tabular}




\begin{tabular}{|c|c|c|}
\hline Página 98.1 & Descrição & Procedência \\
\hline Figura 119 & $\begin{array}{l}\text { Área prospectada Ponta do } \\
\text { Leme }\end{array}$ & Imagem da autora \\
\hline Figura 120 & $\begin{array}{l}\text { Área prospectada Ponta do } \\
\text { Leme }\end{array}$ & Imagem da autora \\
\hline Página 98.2 & Descrição & Procedência \\
\hline Figura 121 & $\begin{array}{l}\text { Área prospectada Ponta do } \\
\text { Leme }\end{array}$ & Imagem da autora \\
\hline Figura 122 & $\begin{array}{l}\text { Área prospectada Ponta do } \\
\text { Pasto }\end{array}$ & Imagem da autora \\
\hline Página 98.3 & Descrição & Procedência \\
\hline Figura 123 & Praia na Ponta do Pasto & Imagem da autora \\
\hline Figura 124 & Ponta Leste - Aquidabã & Imagem da autora \\
\hline Página 98.4 & Descrição & Procedência \\
\hline Figura 125 & $\begin{array}{c}\text { Prospecção Píer e Ponta do } \\
\text { Pasto }\end{array}$ & $\begin{array}{c}\text { Tratada por Ivan Francisco (2008), } \\
\text { Laboratório de Antropologia Biológica da } \\
\text { UERJ }\end{array}$ \\
\hline Página 98.5 & Descrição & Procedência \\
\hline Figura 126 & Prospecção Aquidabã & $\begin{array}{c}\text { Tratada por Ivan Francisco (2008), } \\
\text { Laboratório de Antropologia Biológica da } \\
\text { UERJ }\end{array}$ \\
\hline Página 98.6 & Descrição & $\begin{array}{c}\text { Procedência } \\
\end{array}$ \\
\hline Figura 127 & $\begin{array}{c}\text { Prospecção Praia dos } \\
\text { Maciéis }\end{array}$ & $\begin{array}{c}\text { Tratada por Ivan Francisco (2008), } \\
\text { Laboratório de Antropologia Biológica da } \\
\text { UERJ }\end{array}$ \\
\hline $\begin{array}{c}\text { Página } \\
105.1\end{array}$ & Descrição & Procedência \\
\hline Figura 128 & $\begin{array}{c}\text { Plotagem de todos os pontos } \\
\text { da pesquisa }\end{array}$ & $\begin{array}{c}\text { Tratada por Ivan Francisco (2008), } \\
\text { Laboratório de Antropologia Biológica da } \\
\text { UERJ }\end{array}$ \\
\hline
\end{tabular}




\section{Introdução}

As primeiras idéias desta pesquisa surgiram com a minha participação nas etapas de campo do Projeto Área Arqueológica de Piraquara, coordenado pela professora Nanci Vieira de Oliveira, do Laboratório de Antropologia da Universidade do Estado do Rio de Janeiro. Como veremos adiante, Piraquara localiza-se na Baía da Ribeira, litoral sul fluminense, a oeste da cidade de Angra dos Reis. A minha participação neste programa, que ocorreu entre os anos de 2004 e 2006, permitiu que, durante nossas longas conversas, elaborássemos um projeto de pesquisa na região da Ponta Leste, que, como o próprio nome indica, fica a leste de Angra dos Reis.

Como Piraquara fica ao lado oposto e lá foram identificadas várias estruturas defensivas, denominadas baterias ${ }^{1}$, nossa hipótese era que Ponta Leste também era uma área fortificada e que, Piraquara, a Vila de Angra dos Reis e Ponta Leste estavam ligadas a um sistema defensivo. Dessa forma, a necessidade de defender toda essa região teve sua origem pelo mesmo motivo: especialmente entre os séculos XVIII e XIX era necessário defender a Baía da Ilha Grande da presença de navios estrangeiros e do contrabando de ouro e escravos.

Uma única informação que tínhamos já nos oferecia um grande passo para a pesquisa: em Ponta Leste havia uma fortificação, o Forte do Leme ${ }^{2}$, construído nas primeiras décadas do século XIX, mais precisamente em 1838, segundo a obra de BARRETO (1958, p. 218). Assim, a existência dessa fortificação logo foi relacionada às estruturas defensivas encontradas em

\footnotetext{
${ }^{1}$ Podemos definir baterias como bases de pedra que recebiam canhões. Outra definição, presente no dicionário Kinghost, é uma fileira de bocas de fogo prontas para atirar, ou o lugar onde elas se encontram. Consultado no site: http://www.kinghost.com.br/dicionario em 20/06/2007.

2 É importante fazer um esclarecimento quanto à denominação Ponta Leste. Historicamente a área onde se encontra o Forte do Leme é conhecida como Ponta Leste (ver figuras 1 e 2). No entanto, a carta do IBGE (1974) apresenta subdivisões para a Ponta Leste: Ponta do Leste, Ponta do Pasto (onde está localizado o píer da Petrobrás) e Ponta do Leme, onde foi construído o Forte do Leme (figura 3). Interessa aqui destacar que a denominação Ponta do Leme já aparece no século XIX, nos relatórios da Marinha, o que, talvez, tenha influenciado o nome da construção: Forte do Leme. Mas como os habitantes locais não utilizam essa denominação (figura 4) preferimos manter a que resistiu ao tempo: Ponta Leste.
} 

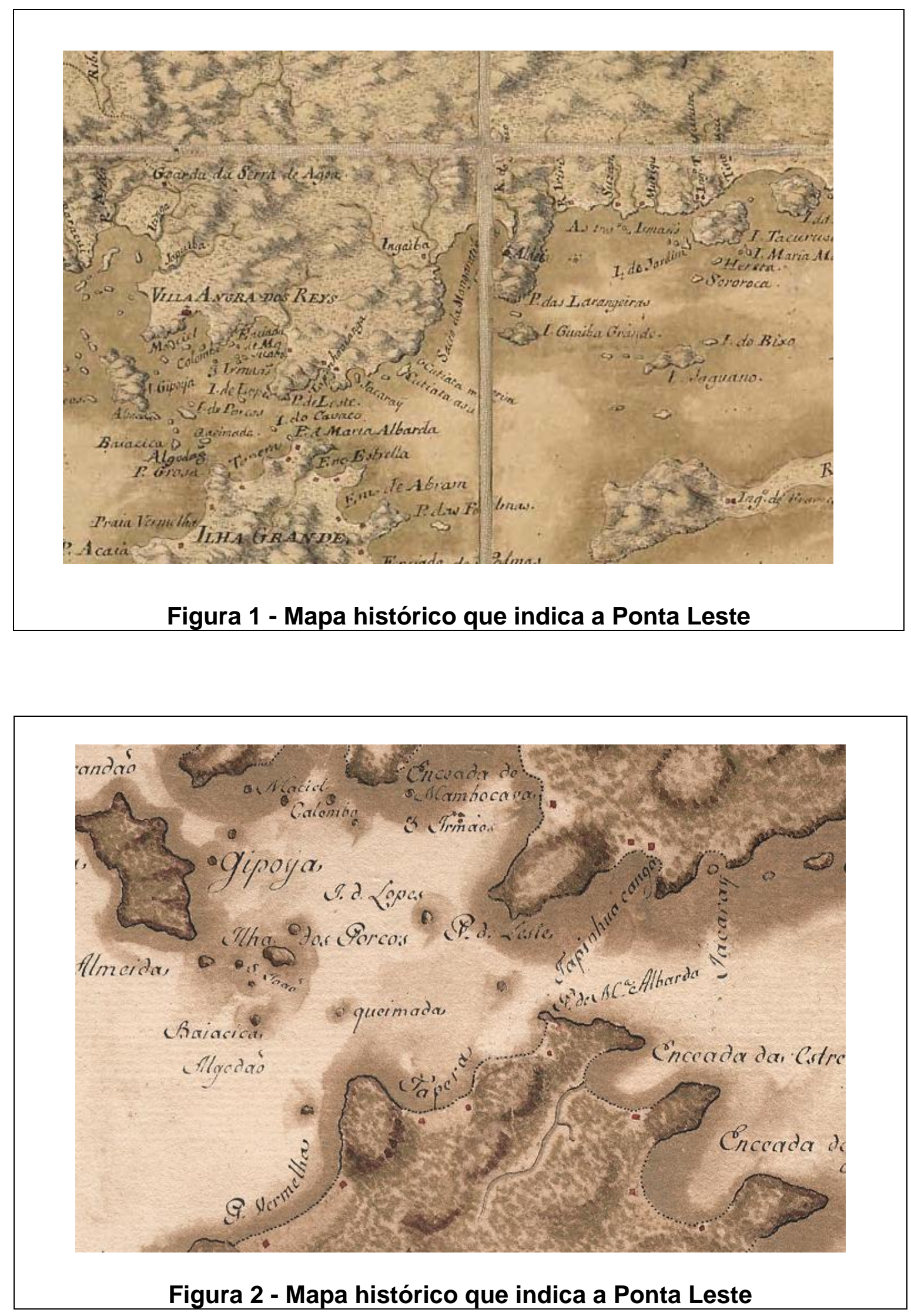


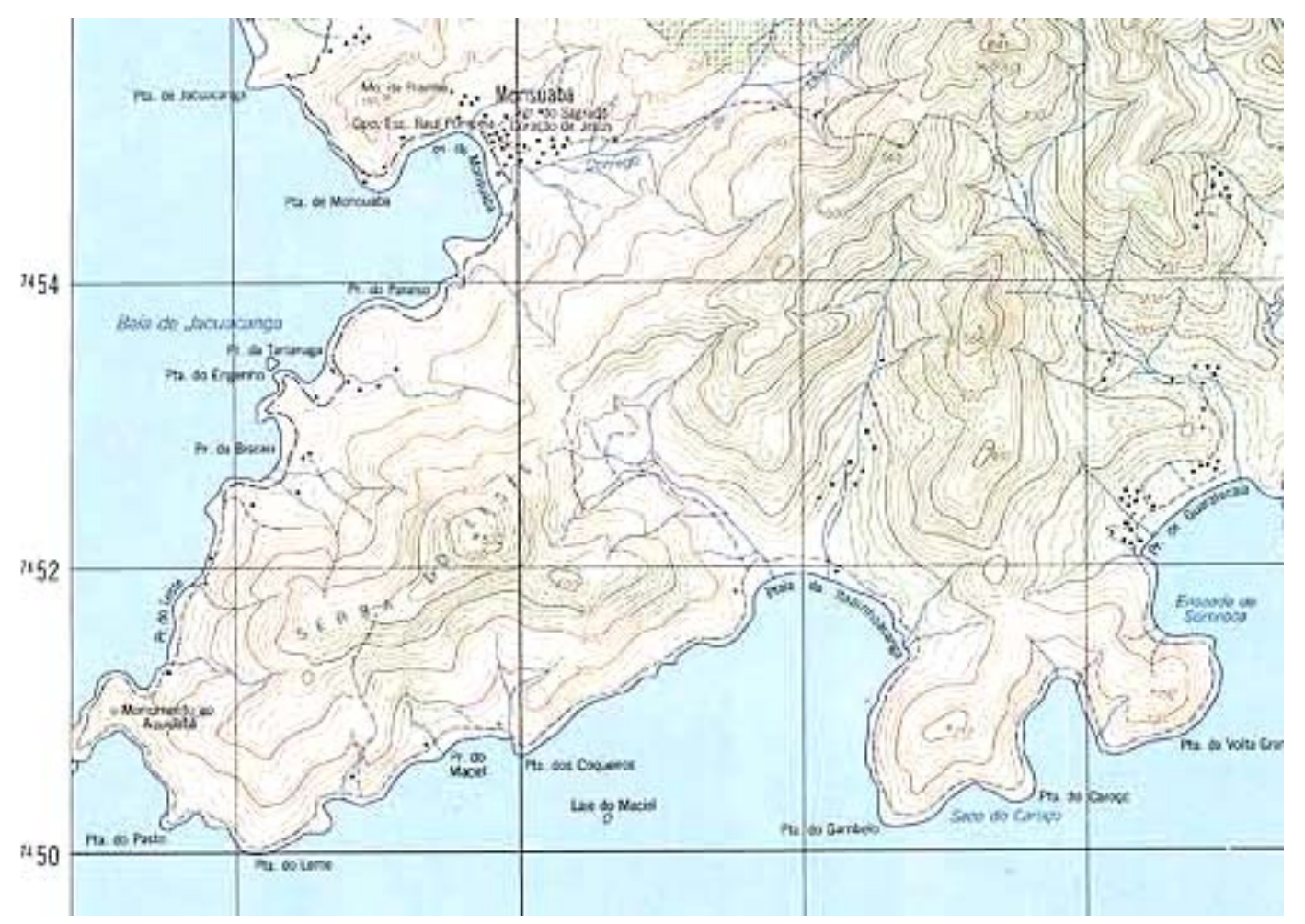

Figura 3 - Carta IBGE (1974)

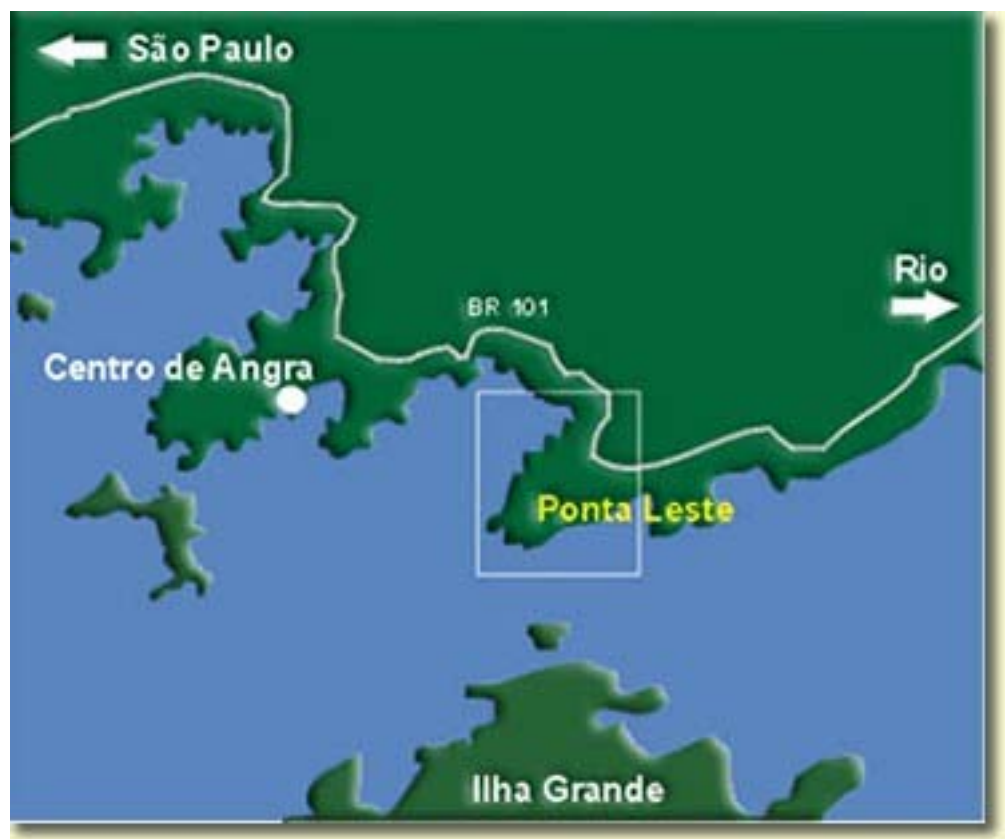

Figura 4 - Ponta Leste 
Piraquara. Em ambos os casos, essas fortificações poderiam ter sido construídas para proteger a vila de Angra dos Reis, na Baía da Ilha Grande.

No entanto, uma questão não era explicada: as diferenças construtivas entre as estruturas encontradas em Piraquara e o Forte do Leme. As primeiras eram simples alinhamentos e bases de pedras dispostos pelos morros de Piraquara e a segunda, uma grande obra de fortificação, composta por quartel, banheiro, galerias subterrâneas e, até mesmo, Casa do Comandante.

Ora, se as estruturas de Piraquara e o Forte do Leme, em Ponta Leste, foram obras defensivas contemporâneas, por que haveria essa diferença tão grande nas construções? De um lado bases de pedras, sem paredes e de outro uma enorme edificação. A partir dessas reflexões tínhamos uma explicação: o Forte do Leme havia sido construído para reforçar um sistema defensivo em Ponta Leste, já formado por baterias e pontos de observação, como em Piraquara, e também na vila de Angra dos Reis, defendida por duas fortificações, o Forte do Carmo e o de São Bento, obras bem mais simples que a do Forte do Leme. Neste caso, esses dois tipos de construção, tão diferentes entre si, foram contemporâneos e o papel dessas estruturas defensivas mais simples era ajudar o Forte do Leme a defender a Baía.

No entanto, ao se pôr em prática as etapas de levantamento documental desta pesquisa, nenhuma referência ao Forte do Leme foi encontrada, especialmente nos documentos oficiais do século XIX, século que havia, supostamente, sido construída a referida fortificação. Dessa maneira, mudamos o foco da pesquisa: deixamos de buscar informações em correspondências oficiais e passamos a procurar em uma fonte histórica diária: o jornal (Gazeta de Angra dos Reis, entre os anos de 1908 e 1911).

Essa fonte permitiu-nos compreender que o Forte do Leme não estava em funcionamento e, muito menos, havia sido construído no século XIX, como afirma o Exército na obra de BARRETO (1958, p. 218). Pelo contrário, ela mostrou que esse Forte foi erguido em princípios do século XX, como parte de um plano de transformar a região da Ilha Grande em um porto militar do Brasil, que não deu certo. Nas palavras de Mendes,

"Tão segura e tão apropriada a baía de Angra dos Reis que (...) o Estado Maior da Armada começou a pensar na 
instalação de um porto militar em Jacuecanga, e, prevendo, no conjunto, a transferência também da Escola Naval para a Praia da Tapera, como se denominava antigamente a Enseada Batista das Neves. Infelizmente a idéia da instalação do porto militar em Angra dos Reis foi abandonada, depois da terrível catástrofe do encouraçado Aquidabã ${ }^{3}(\ldots) "$.

(MENDES, 1983, p. 6)

De uma forma geral, a construção do Forte do Leme, em Ponta Leste, o prolongamento da Estrada de Ferro a Itacurussá e a Angra dos Reis, a construção da Escola de Grumetes (Escola Naval) na região e a transferência da sede do Arsenal da Marinha faziam parte deste plano, como nos mostram as reportagens a seguir,

“(...) quando Ministro da Guerra o actual chefe da Nação ${ }^{4}$, espossando, depois de estudos próprios, esse antigo voto, resolveu fortificar aquella posição, fazendo construir as obras de defesa da Ponta do Leme, que são as avançadas do systema, e tendem, se prosseguidas no seu conjunto, a crear uma verdadeira e inexpugnável base naval no golfo daquella ilha. Nós vamos além neste capítulo: com o laudo do inolvidável Calheiros da Graça, do Almirante Noronha, e muitos outros, fazemos votos para que o futuro da Ilha Grande se transforme n'um grande porto militar (como se dispunha a fazel-o a casa Armstrong, no tempo do Presidente Rodrigues Alves), construindo-se ali o novo arsenal da Marinha (...). O artilhamento da Ponta do Leme, o prolongamento da estrada de ferro a Itacurussá e a Angra e a criação da grande escola de Grumetes alli, são obras de vasto alcance, preparatórias (...) à realização do velho sonho - a base naval do Golpho da Ilha Grande. A invasão pelas forças de Duclerc (...) mostraram como é fácil qualquer operação desembarque e ataque por terra ao Rio de Janeiro (...) (grifo meu)". 5

(Reportagem "A defesa de nosso litoral", Gazeta de

Angra, n. ${ }^{\circ} 26,25 / 06 / 1911$ )

\footnotetext{
${ }^{3}$ O Aquidabã pertencia à Primeira Divisão Naval quando realizou, em 1906, uma viagem à llha Grande para levar uma comitiva com a função de inspecionar a Baía de Jacuecanga para a escolha do local onde seria construído o Arsenal da Marinha. Entretanto, quando estava fundeado na Baía de Jacuecanga, houve uma explosão, cuja causa até hoje não foi comprovada. No total foram 112 mortos. Sobre o assunto consultar, http://www.naufragiosdobrasil.com.br/naufaquidaban.htm

${ }^{4} \mathrm{O}$ documento refere-se ao Presidente Marechal Hermes da Fonseca.

${ }^{5}$ Vale destacar, sobre essa reportagem, quando esta se refere ao desejo de fazer da llha Grande um Porto Militar, como se dispunha a fazer a casa Armstrong, que, como dito, o plano proposto era transferir a sede do Arsenal da Marinha no Rio de Janeiro para a região da llha Grande. E, em uma das etapas de levantamento documental, ocorrida na cidade do Rio de Janeiro, foi encontrada a planta deste Arsenal, de 1906, assinada por W. G. Armstrong Witworth Companhia Limitada.
} 
“(...) S. Ex. quando Ministro da Guerra, em seu relatório de 1908, pedindo a construção do ramal férreo de Angra dos Reis, e mandando erguer as primeiras baterias da Ponta do Leme, indicou de modo claro as duas idéias sobre o assumpto (grifo meu)."

(Reportagem "Terra e Mar - A questão de uma Base

Naval", Gazeta de Angra dos Reis, n 34, 30/07/1911)

Dois relatórios do final do século XIX trazem também informações sobre a Ponta Leste, onde seria construído o Forte do Leme. Neles, a região é vista como um ponto importante de defesa do litoral. Segundo as palavras dos autores,

"As pontas chamadas Camorim, Espia e de Leste, que fecham a Bahia de Jacuecanga são terrenos elevados, por sua configuração e natureza parecem prestar-se conjunctamente a ilhas visinhas a um systema completo de defeza (...). Valorisados os terrenos com o começo dos trabalhos para fundar-se o Arsenal, e ainda mais pela construção do Ramal de Santa Cruz até Jacuecanga ou Angra dos Reis, não póde restar dúvida de que o Governo obteria facilmente quantia mais que sufficiente para indenisar-se da despeza com a acquisição de todas as terras já mencionadas, e até mesmo das que se tornassem precisas nas pontas de Leste e Camorim para fortificações (...) (grifo meu)".

(Informações sobre a Baía de Jacuecanga prestadas ao Sr. Comandante Elisário José Barbosa, Ministro da Marinha, pelo Contra Almirante Graduado João Cândido Brasil, Fevereiro de 1895, Rio de Janeiro, Typ. Leuzinger, 1896, p. 11)

"Creio seguras as condições de defesa. (...) Lançando-se as vistas sobre uma planta hydrographica de toda essa região, verifica-se o quanto a bahia de Jacuecanga está distanciada do oceano. Para chegar à sua entrada, indo do Sul, é necessário atravessar uma distância de 15 milhas (...), nesse trajecto um meandro de ilhas elevadas intercepta a passagem, e todas ellas estão perfeitamente dispostas para excellentes pontos de defesa. A travessia, portanto, de uma esquadra para inutilisar o nosso primeiro estabelecimento naval não seria missão de fácil empenho: ela teria que travar combates parciais e sofrer grandes damnos, antes de enfrentar com outras fortificações que naturalmente iam defender a entrada do porto. Se o trajecto da mesma entrada fosse feito pelo canal de Leste, as condições não se tornavam mais favoráveis: ela seria obrigada a passar pela mais curta distância de terra, e, ao aproximar-se da Ponta do Leme, estaria sujeita aos 
fogos crusados do estreito canal ahi formado com a Ilha Grande (grifo meu)".

(A Bahia de Jacuecanga. Relatório da Comissão Hydrographica dirigida pelo Capitão de Mar e Guerra Francisco Calheiros da Graça, dezembro de 1895, Typ. Leuzinger - 1896, p. 36-37)

Por mais que o plano de transformar a região da llha Grande em um porto militar não tenha dado certo, o Forte do Leme e a Escola de Grumetes ${ }^{6}$ tiveram suas obras concluídas. As reportagens da Gazeta de Angra dos Reis apontam que o primeiro teve sua construção iniciada em 1909 e foi inaugurado em 1911 e a Escola de Grumetes teve suas obras iniciadas em 1911 (MENDES, 1983, p. 6), ambos sob o comando do Capitão de Arma de Engenharia Rosalvo Mariano Silva. Sobre o início da construção do Forte do Leme e sua inauguração encontramos os seguintes documentos,

"No dia 9 do corrente, à tarde, ancoraram em nosso porto, os rebocadores Marechal Vasques e Tuyuty, trazendo à reboque um grande batelão carregado de materiaes; destinados ao serviço de construcção da fortaleza da Ponta do Leme, neste município (...). O Dr. Rosalvo ${ }^{7}$ está encarregado de dirigir as obras de construcção da referida fortaleza, que já começaram (...) (grifo meu)".

(Noticiário da Ponta do Leme, Gazeta de Angra dos

Reis, n. $\left.{ }^{\circ} 24,14 / 06 / 1909\right)$

"Visita ao Forte do Leme: Ante-hontem o senhor Marechal Hermes (...) fez uma visita ao Forte do Leme, cujas obras de construção estão sendo executadas sob a imediata direção do sr. Capitão de Engenharia do Exército Rosalvo Mariano Silva (...). S. Ex. percorreu aquella praça de guerra (...). Foram feitos dois disparos dos seus poderosos canhões (...) (grifo meu)".

(Visita Presidencial: Escola de Grumetes - Forte do Leme - Marechal Hermes da Fonseca, Gazeta de Angra dos Reis, n. $\left.{ }^{\circ} 44,29 / 10 / 1911\right)$

\footnotetext{
${ }^{6}$ Nas palavras de Mendes, “(...) em 1911 tem início a construção da Escola de Grumetes, (...), cujo edifício em 1914, (...), foi aproveitado para sediar a Escola Naval (...). Permaneceu a Escola Naval em Angra dos Reis até o ano de 1921, quando suas instalações passaram a abrigar uma Escola de Grumetes, que funcionou até 1950" (MENDES, 1983, p. 6). Hoje, este mesmo prédio é sede do Colégio Naval da cidade.

${ }^{7}$ Aqui vale destacar que a Fé de Ofício do Capitão Rosalvo Mariano Silva que indica que o mesmo foi dispensado deste serviço no ano de 1916. Segundo este documento, "(...) foi dispensado de auxiliar da Comissão de defeza do littoral do estado do Rio de Janeiro e por ter sido a referida comissão extincta pelo aviso número um (...). Em virtude do disposto no alludido aviso foi posto à disposição desta repartição para ultimar a construção das obras do quartel da Bateria da Ponta do Leme, em Angra dos Reis (...)" (Fé de Offício do Senhor Capitão da Arma de Engenharia Rosalvo Mariano Silva, Fevereiro de 1916, AHE, Setor Pessoal).
} 
A partir das informações documentais e do reconhecimento da construção defensiva em campo percebemos que quando o Forte do Leme foi construído, as baterias de Piraquara e o sistema defensivo da Vila de Angra dos Reis, que veremos adiante, já estavam inoperantes. Isso significa que essa construção defensiva nada tem a ver com a defesa da região para evitar o contrabando de ouro, escravos ilegais e a constante presença de corsários, tão comuns entre os séculos XVIII e XIX.

Mas então, a Ponta Leste não era um ponto fortificado antes da construção do Forte do Leme no século XX? Em conversa com o coronel Dartanhan (comunicação pessoal) do Exército Brasileiro, que estuda essa fortificação, o mesmo disse que se havia alguma estrutura defensiva na região, provavelmente foi destruída com a construção do Forte do Leme, erguido no nível mais alto de um dos morros da Ponta Leste.

No entanto, as construções identificadas em Piraquara não estão apenas dispostas em níveis mais altos (geralmente essas construções referemse aos pontos de observação ou pontos de vigia), pois há também construções bem próximas ao nível do mar. Nesse sentido, com o auxílio de dois moradores da região, executamos nossa primeira etapa de campo e, já nesta etapa, pudemos identificar duas estruturas que apresentam a mesma técnica construtiva e forma de implantação no terreno, que possibilita excelente visibilidade do litoral. Essas são características que podem indicar as mesmas estratégias defensivas encontradas em Piraquara.

Dessa forma, esta pesquisa tem como objetivos indicar essas estruturas e apresentar o contexto defensivo da região de Angra dos Reis. Para tanto, a mesma foi organizada em quatro capítulos. O primeiro deles discutirá os aspectos teórico-metodológicos na área de Arqueologia Histórica, incluindo neste item, uma introdução sobre sua origem, uma apresentação de trabalhos produzidos no Brasil, uma reflexão sobre o possível e necessário diálogo entre a fonte material e a fonte escrita e, por fim, o contexto histórico do litoral sul fluminense.

O segundo capítulo, mais específico, apresentará uma discussão histórica, enfatizando o contexto econômico da Vila de Angra dos Reis, com 
objetivo de justificar sua defesa, os resultados da pesquisa arqueológica em Piraquara e a interpretação sobre as estratégias defensivas desta região e da vila de Angra dos Reis, a partir da análise das fontes documentais, iconográficas e materiais. O terceiro capítulo descreverá as etapas de campo ocorridas em Ponta Leste e, por fim, o quarto capítulo apresentará as conclusões do presente estudo. 


\section{CAPÍTULO I}

\section{ASPECTOS TEÓRICOS DA ARQUEOLOGIA HISTÓRICA E SUAS APLICAÇÕES EM ESTUDOS ESTRATÉGICOS}




\section{A Arqueologia Histórica e suas discussões}

A História da Arqueologia é, antes de tudo, uma história de idéias, de descobertas e de formas variadas de olhar o passado, e cada olhar possui relações com seu próprio tempo. Hoje, chamamos de arqueólogo aquele que se vale de modernos conceitos teóricos, técnicas sofisticadas e grandes organizações de trabalho para explicar a história humana (ROBRAHNGONZÁLEZ, 2006, p. 64), pois todos os grupos humanos, dos mais antigos aos mais modernos, possuem explicações, não somente sobre sua história recente, mas sobre suas origens mais remotas (SOUZA, 1991, p. 15).

Dentro deste contexto encontram-se discussões sobre a Arqueologia Histórica, uma área de pesquisa que tem passado por um intenso debate nos últimos anos, a respeito de definição, perspectivas e objetos específicos, com o objetivo de mostrar que ela não é uma simples serva ou auxiliar da documentação escrita e da pesquisa histórica ${ }^{8}$, pois, as análises de fontes materiais podem não só comprovar as informações textuais, como também podem contradizer, complementar e, até mesmo, oferecer dados ausentes nos documentos escritos (FUNARI, 2002, p. 107).

No entanto, ao se pôr em prática as investigações na área de Ciências Humanas, sobretudo, quando se estuda alguma sociedade que produziu, em grande escala, documentos escritos, uma questão ainda é recorrente: não é suficiente ler e interpretar textos se nós pretendemos compreender e explicar períodos históricos? (ANDRÉN, 1998, p. v).

Assim, sempre foi comum encontrar entre muitos pesquisadores uma tendência à marginalização dos estudos da Arqueologia Histórica, porque os resultados arqueológicos, neste caso, são vistos como confirmações

\footnotetext{
${ }^{8}$ Um bom exemplo de a Arqueologia ser vista como uma disciplina auxiliar da História, encontramos na obra de CARR (1996). Ao tratar da função do historiador, este autor usa as seguintes palavras, "(...) elogiar um historiador por sua exatidão é o mesmo que elogiar um arquiteto por usar a madeira mais conveniente ou o concreto adequadamente misturado. Tratase de uma condição necessária do seu trabalho, mas não sua função essencial. É precisamente para assuntos deste tipo que é permitido basear-se no que se tem chamado de "ciências auxiliares" da história - arqueologia, epigrafia, numismática, cronologia e outras. Não é exigido do historiador ter a perícia especial que capacita o especialista a determinar a origem e o período de um fragmento de cerâmica ou mármore, a decifrar uma inscrição obscura (...)" (CARR, 1996, p. 47).
} 
desnecessárias do que já se conhece ${ }^{9}$ (FINLEY, 1994, p. 104) e a Arqueologia, por sua vez, é tida como uma técnica, capaz de recuperar, descrever e classificar com objetividade documentos materiais, um conjunto de informações a serem encaminhadas a outros especialistas (COURBIN, 1988).

Entretanto, os intensos debates mostram que a Arqueologia é ilimitada e importante, mesmo no estudo das sociedades letradas. Tradicionalmente, a Arqueologia Histórica era entendida como o estudo arqueológico do período posterior à chegada dos europeus no continente americano (ORSER, 2000, p. 18). Entretanto, hoje em dia, essa definição tem sido posta à prova. Parcialmente, essas mudanças têm sido resultados de muitas reflexões feitas por pesquisadores brasileiros (FUNARI, 2003, s. p.).

Elaborando o trajeto dessa disciplina, sabemos que uma das primeiras práticas relacionadas à Arqueologia surgiu na Europa, no século XIX, a partir de um interesse antiquário por objetos e monumentos em geral; posteriormente, a Arqueologia saltou para a História da Arte e vinculou-se à Filologia. Neste contexto, esteve preocupada com os vestígios materiais das sociedades que estavam nos fundamentos dos modernos Estados Nacionais, especialmente, Grécia e Roma Antigas, seguido pelas sociedades médioorientais, ou seja, egípcia, mesopotâmica e hebraica (FUNARI, 1999, p. 40) ${ }^{10}$. Dessa forma, a Arqueologia na Europa tem sua base ligada ao caráter histórico, como o estudo das raízes dos próprios europeus (TRIGGER, 2004, p. 381). Nas palavras de Andrén,

"The historical archaeologies in Europe are like a mosaic of different (...) traditions. The different parts consist of classical archaeology, provincial Roman archaeology, Bizantine archaeology, medieval archaeology, postmedieval archaeology, and industrial archaeolgy".

(ANDRÉN, 1998, p. 9)

Nos Estados Unidos a Arqueologia seguiu um caminho diferente. Ali, desenvolveu-se como parte da Antropologia, como o estudo da cultura material

\footnotetext{
${ }^{9}$ BURKE (1992) também trata deste assunto. De acordo com este autor, “(...) é difícil não imaginar se a cultura material está sendo utilizada para fazer algo mais do que confirmar uma hipótese sobre e evidência literária. Pode o arqueólogo posterior a 1500 aspirar mais (...)? De forma bastante irônica, a história da cultura material (...) é baseada menos no estudo dos artefatos em si, do que nas fontes literárias" (BURKE, 1992, p.28-29).

${ }^{10}$ Sobre o assunto, consultar também TRIGGER, 2004, p. 41-85 e CLARK, 1985, p. 55-74.
} 
dos povos ameríndios, em fins do século XIX. Somente na década de 1960, surgiu o termo "Arqueologia Histórica", para referir-se ao estudo de um período histórico específico, o moderno, ligado a conceitos como colonialismo, capitalismo, globalização e eurocentrismo (ORSER, 1999, p. 94).

Formou-se assim, entre os norte-americanos, uma fronteira bem definida entre a pesquisa pré-histórica, nas mãos dos pré-historiadores, ligada à Antropologia, que analisa o modo de vida dos índios e Arqueologia Histórica, como o estudo das entidades européias e euro-americanas pós-colonização, ligada à História (FUNARI, 1999, p. 39).

No início, a Arqueologia Histórica americana enfatizou o estudo dos anglo-saxões protestantes, vistos como fundadores da pátria americana. Paulatinamente, essa postura foi sendo superada, com a inclusão dos espanhóis e franceses que colonizaram grande parte da região que formaria os Estados Unidos (FUNARI, 2003, s.p.). E, mais tarde, os pesquisadores passaram a centrar sua atenção nos povos afro-americanos e nos indígenas em contato com a sociedade anglo-americana. Nas palavras de Zanettini,

\begin{abstract}
"Buscando escapar ao etnocentrismo ou eurocentrismo que Ihe foi flagrante em sua forma inicial, a Arqueologia Histórica norte-americana deixa de dedicar-se exclusivamente às marcas da expansão material européia e sua adaptação ao solo norte-americano (...), passando a incorporar paulatinamente o outro - no caso o elemento autóctone - e (...) reincorporando as vozes da África (...) e as chamadas minorias e grupos marginalizados (...)".
\end{abstract}

(ZANETTINI, 2005, p. 15)

Dessa forma, a disciplina surgida nos Estados Unidos tem passado por grandes mudanças. Entretanto, no contexto mundial, a definição americana que se sustenta na chegada de Colombo às Américas é limitada e artificial ${ }^{11}$. E, como resultado das discussões que envolvem esse tema, tem-se propugnado que a Arqueologia Histórica abranja, seja o estudo do mundo moderno, seja o estudo de todas as sociedades com escrita (FUNARI, 2005, p. 4).

Em outras palavras, que a Arqueologia Histórica se defina como o estudo da cultura material de todas as sociedades que conseguiram registrar

\footnotetext{
${ }^{11}$ Nas palavras de Funari, "(...) os homens não foram sempre e em toda parte capitalistas! (...)" (FUNARI, 2004-2005, p. 2).
} 
sua história, através da escrita ${ }^{12}$. Assim, a Arqueologia do período posterior a 1492 da América seria uma das muitas possibilidades para a pesquisa na área de Arqueologia Histórica (FUNARI, JONES e HALL, 1999, p.7).

No que diz respeito à Arqueologia Histórica brasileira, esta foi importada dos Estados Unidos, durante a ditadura militar e, principalmente a partir da década de 1980, em parte como resultado da restauração das liberdades públicas $^{13}$ se multiplicaram as pesquisas que deram ênfase na diversidade social brasileira (FUNARI, 2004-2005, p. 3), como veremos a seguir.

\footnotetext{
${ }^{12}$ Um exemplo do desejo de formar uma Arqueologia Histórica Mundial é a publicação do livro Historical Archaeology - Back from the Edge, 1999, editado por Pedro Paulo Abreu Funari, Martin Hall e Siân Jones, no qual todos os colaboradores compartilham a idéia de uma Arqueologia Histórica unânime em definir seu tema dentro de um contexto internacional, que não está confinado apenas à época do colonialismo europeu.

${ }^{13} \mathrm{O}$ momento anterior à década de 1980 é o da implantação do regime militar em 1964. A partir da implantação desse regime político, surgiu uma escola arqueológica que atingia interesses mais amplos, condicionados pelo poder político nacional. Assim, nasce o PRONAPA - Programa Nacional de Pesquisas Arqueológicas, coordenado pelo casal Clifford Evans e Betty Meggers, que iniciou um processo de difusão das teorias empiristas. Nas palavras de FUNARI, "esse grupo formou uma confraria que passaria a controlar escavações, financiamentos, publicações, postos arqueológicos e museus, e, não menos importante, limitar a difusão de perspectivas diversas. Mesmo estudiosos americanos, que tivessem posições interpretativas diferentes, históricas, foram sistematicamente impedidos de trabalhar" (FUNARI, 1998, p. 20). No entanto, há pesquisadores (e.g. SOUZA, 1991, DIAS, 1995) que afirmam que o PRONAPA foi a base do processo de profissionalização dos pesquisadores no Brasil, através da implantação de teorias e métodos científicos que permitiram uma padronização metodológica. Dessa forma, o Programa teria possibilitado a formação de uma identidade para a arqueologia brasileira, com a construção de um quadro panorâmico sobre a pré-história do Brasil. Para mais informações consultar MILHEIRA, R. Arqueoistoriografia e Identidade no contexto das pesquisas arqueológicas em Sambaquis. Disponível no site http://www.cph.ipt.pt/angulo2006/img/01-02/sambaquis.pdf. Acesso em 10/04/2008.
} 


\section{Perspectivas da Arqueologia Histórica no Brasil}

Desde o fim da ditadura militar até os dias atuais, houve um considerável aumento das produções acadêmicas em Arqueologia Histórica no Brasil. Com o objetivo de contribuir com o diálogo permanente dessa produção científica, é importante apresentar alguns pesquisadores, tradicionalmente citados nessa área ${ }^{14}$, e também aqueles que tratam do tema proposto neste trabalho, fortificações.

Podemos iniciar essa apresentação com o docente da Pontifícia Universidade Católica do Rio Grande do Sul, Arno Alvarez Kern, que, desde a década de 1980, foi pioneiro na Arqueologia Histórica das missões jesuíticas (e.g. KERN, 1986, 1987, 1991, 1997, 2006), preocupada com os vestígios arqueológicos de interação entre índios e europeus. Até hoje, este pesquisador está vinculado a projetos que buscam compreender e refletir sobre os sítios históricos do litoral, localizados na América Meridional, o passado colonial da região do Prata, a ação dos bandeirantes no Sul do Brasil e os procedimentos teórico-metodológicos da Arqueologia Histórica (e.g. KERN, 1998, 2000, 2002).

Da mesma década, temos a arqueologia dos sertanejos de Canudos, no Nordeste, cujo trabalho contou com a participação do pesquisador Paulo Eduardo Zanettini, envolvido num projeto de implantação de um parque histórico na região. Nesse sentido, as pesquisas arqueológicas contribuíram para a constituição do Parque Estadual de Canudos e tiveram como um de seus principais objetivos, o registro e o mapeamento de ocorrências associadas aos conflitos bélicos: fragmentos de louças, vidros, elementos metálicos (projéteis, cápsulas, pentes, cantis), estruturas de dimensões variadas (tocas, trincheiras), áreas de sepultamento, entre outros (e.g. ZANETTINI, 2003). Cabe ressaltar ainda que este pesquisador, recentemente, defendeu sua tese de doutorado em Arqueologia Histórica, sobre as Casas Bandeiristas, sedes de fazendas construídas ao redor da vila de Piratininga no

\footnotetext{
${ }^{14}$ É necessário destacar que são inúmeras as possibilidades de apresentação das pesquisas desenvolvidas na área de Arqueologia Histórica, porém, uma extensa apresentação fugiria do escopo deste trabalho. Entretanto, os pesquisadores aqui citados têm seus trabalhos multiplicados por outros pesquisadores. Dessa maneira, indicamos algumas pesquisas na área: BORNAL, 1995; MAXIMINO, 1997; FRANCHI, 1999; MACHADO, 2004; NAJJAR, 2005; UESSLER, 2006; QUEIROZ, 2006; ZEQUINI, 2006; BRANCHELLI, 2007 entre outras.
} 
decorrer dos séculos XVII e XVIII, que foram reexaminadas pela óptica da Arqueologia (ZANETTINI, 2005).

Da década de 1980 há também os estudos desenvolvidos pelo professor associado da Universidade Federal de Minas Gerais (UFMG), Carlos Magno Guimarães, sobre os quilombos da região mineira (e.g. GUIMARÃES e LANA, 1980, GUIMARÃES, 1988, 1989, 2000, 2002, 2005). Nos últimos anos, além destes estudos, este pesquisador privilegia compreender o campesinato e a mineração colonial no século XVIII (e.g. GUIMARÃES, 1996, GUIMARÃES, NASCIMENTO, SILVA e VELOSO, 2005).

Outro nome de referência para a Arqueologia Histórica é o do professor da UFMG, Andrés Zarankin, cuja experiência soma mais de trinta trabalhos na área, tanto no exterior, quanto no Brasil. Suas pesquisas contemplam reflexões e análises sobre teoria e metodologia, a relação entre arqueologia e arquitetura, o estudo dos cemitérios dos "desaparecidos" durante a ditadura militar etc. (e.g. ZARANKIN, 2005, 2008; FUNARI e ZARANKIN, 2006). Cabe destacar ainda que, ambos os pesquisadores, Guimarães e Zarankin, são editores da Revista Vestígios: Revista Latino Americana de Arqueologia Histórica, um espaço de discussão de produção teórica e de diálogo entre pesquisadores de diferentes países sobre Arqueologia Histórica, editada pela UFMG.

De igual importância, é necessário citar as pesquisas desenvolvidas sobre quilombos no Nordeste, a partir da década de 1990, por Pedro Paulo Abreu Funari, professor da graduação e pós-graduação da Universidade Estadual de Campinas (UNICAMP), da pós-graduação da Universidade de São Paulo (USP) entre outros. As pesquisas sobre o quilombo dos Palmares forneceram importantes informações sobre as ocupações da região e a cultura material afro-brasileira. Estes estudos, não só possibilitaram uma melhor compreensão de como esta comunidade foi criada e mantida, mas também a identificação de que sinais arqueológicos possam ser resultados do processo de contato entre diferentes grupos culturais (OLIVEIRA, 2002, p. 6).

Atualmente, a produção científica desse pesquisador, em Arqueologia Histórica, abrange desde a discussão teórica até a compreensão da cultura material em contextos históricos, tanto no mundo antigo, quanto no moderno (e.g. DOMÍNGUEZ e FUNARI, 2008; FUNARI, 2003, 2005, 2006 e 2007). Faz- 
se necessário destacar ainda os trabalhos desenvolvidos em parceria com Nanci Vieira de Oliveira, professora da UERJ, sobre os aspectos defensivos do litoral sul fluminense, mais precisamente em Piraquara, Angra dos Reis, como será apresentado adiante (e.g. FUNARI e OLIVEIRA, 2005 e OLIVEIRA e FUNARI, 2007).

Outra pesquisadora de extrema importância e referência para a Arqueologia Histórica é a docente do programa de pós-graduação do MAE, arqueóloga do Museu Paulista/USP e coordenadora do Núcleo de Arqueologia da Universidade Braz Cubas, Margarida Davina Andreatta. Sua produção científica é de amplo espectro e abrange pesquisas realizadas no Programa de Arqueologia Histórica no município de São Paulo. Nesse sentido, podemos citar prospecções e escavações em locais públicos e privados do município, como Casa do Grito, no Ipiranga, Bairro da Sé, Bairro do Tatuapé. Além disso, há inúmeras pesquisas desenvolvidas em fazendas coloniais, engenhos, antigas igrejas, indústrias etc. (e.g. ANDREATTA, 1986, 1991, 1992a e 1992b, 2003).

Partindo para um diálogo mais específico, é possível perceber que com o aumento considerável da produção científica em Arqueologia Histórica, a quantidade de fontes materiais e sujeitos analisados são variados e uma das muitas possibilidades de estudos é sobre o sistema defensivo do Brasil. As pesquisas desenvolvidas com esse tema, na área de Arqueologia, ainda são poucas, se comparadas ao número de construções defensivas espalhadas pelo país. Mas muitos são os estudos feitos por outros pesquisadores, como as duas obras de referência sobre o assunto, desenvolvidas por membros do Exército Nacional.

A primeira delas é a do coronel Anníbal Barreto, "Fortificações do Brasil", de 1958. Essa obra constitui um levantamento dessas construções, estimadas em cerca de 160, convenientemente distribuídas por todo o território nacional. Sem se deter em questões relacionadas aos critérios de implantação dessas obras, o autor limitou-se a apresentá-las, dedicando cada capítulo a um ou mais pontos estratégicos do Brasil, a citar como exemplos, São Paulo, Rio de Janeiro, Maranhão, Paraíba, Alagoas, entre outros. E, ao tratar de cada uma dessas regiões, o mesmo indicou alguns dados informativos: etapas de 
construção, as reformas que sofreram ao longo do tempo, número de contingente de soldados, número de artilharia etc.

O segundo trabalho é o do tenente coronel Antônio Henrique Osório Noronha, "Fortificações Construídas pelos portugueses no Brasil", 1982, cujo objetivo principal foi atualizar a obra de BARRETO, citada anteriormente. Dessa forma, o mesmo obedece à organização do trabalho precedente, tendo o cuidado de não incluir as fortificações construídas por outros países que não Portugal. Além disso, o autor forneceu dados adicionais, como por exemplo, o estado de conservação atual das construções (SILVA, 1991, p. 161).

No que diz respeito às pesquisas desenvolvidas sobre fortificações na área de Arqueologia Histórica, um nome de referência para o assunto é o do professor do programa de pós-graduação em Arqueologia da Universidade Federal de Pernambuco (UFPE) e coordenador do laboratório de Arqueologia desta Universidade, Marcos Antônio de Albuquerque. Seus estudos contemplam reflexões sobre as relações entre Arqueologia Histórica, arquitetura e salvamento, análises sobre igrejas, e, principalmente, fortificações.

Os trabalhos realizados pelo professor Marcos Albuquerque e a equipe do laboratório de Arqueologia da UFPE, ficam disponíveis na internet e apresentam dados sobre as construções defensivas (nome, designação popular, número de registro, nome de tombamento, se há referência documental, contexto histórico, localização). Além disso, há informações adicionais: ocupação atual do sítio, condições para visitação, estado de conservação, técnicas arqueológicas utilizadas durante as pesquisas e, principalmente, o que a pesquisa arqueológica permitiu identificar. Esses trabalhos envolvem de uma forma geral, prospecção, escavação, plotagem, documentação fotográfica entre outros.

Nesse sentido, há exemplos de pesquisas arqueológicas desenvolvidas, especialmente, sobre as fortificações de Pernambuco ${ }^{15}$. Podemos citar a do Forte Real do Bom Jesus, construído por volta de 1630, no Recife. A pesquisa

\footnotetext{
${ }^{15}$ As informações sobre as pesquisas arqueológicas coordenadas pelo docente Marcos
} Antônio de Albuquerque encontram-se disponíveis no site http://www.magmarqueologia.pro.br. 
arqueológica revelou parte do fosso, as bases das muralhas e do terrapleno ${ }^{16}$, assim como grande quantidade de munições e objetos de uso pessoal dos combatentes (e.g. ALBUQUERQUE e LUCENA, 1988). No Forte do Brum, construído pelos holandeses no século XVII, as pesquisas indicaram vestígios que remontam às primeiras construções, contribuindo para a análise dos sujeitos que construíram e combateram nesta fortificação. De uma forma geral, foram identificados pregos, que provavelmente sustentaram as tábuas de contenção das muralhas; louças, que permitiram resgatar informações quanto ao cotidiano dos diferentes ocupantes do forte; projéteis, que passaram nas mãos de atacantes e de defensores; cachimbos, tanto holandeses quanto portugueses, peças de jogos, a cacimba, que se encontrava totalmente soterrada, mas que à época garantiu o abastecimento de água, entre outros (e.g. ALBUQUERQUE, 2008).

Sobre as pesquisas realizadas no Forte Orange, construído pelos holandeses na llha de Itamaracá, em 1631, e reformado no governo de Maurício de Nassau, foi possível identificar vários tipos de material arqueológico, tais como: cerâmica, artigos bélicos, ferramentas, objetos religiosos e, além disso, foram descobertas estruturas, até então desconhecidas nesta construção: o fosso, os alicerces dos quartéis, a casa de pólvora, a muralha etc. Esta pesquisa fez parte do projeto, iniciado em 2000, em parceira com MOWIC Foundation (e.g. ALBUQUERQUE e LUCENA, 2003; ALBUQUERQUE, 2006).

De igual importância são os estudos desenvolvidos em construções defensivas de pequeno porte, como redutos e baterias. Exemplo disso foi a análise feita no Reduto do Tejucupapo, localizado no município de Goiânia, em Pernambuco. Neste local, a prática arqueológica permitiu recuperar o fosso e identificar a paliçada que o cercava. Sobre a Bateria de Calhetas, construída em Cabo de Santo Agostinho, a pesquisa feita através de levantamento textual, prospecções, plotagem e documentação fotográfica, alertou sobre o risco de destruição do sítio arqueológico ${ }^{17}$.

\footnotetext{
${ }^{16}$ Terrapleno pode ser definido como uma "superfície plana, formada por um aterro, para fazer um terraço ou servir como via de comunicação". Consultado no site: http//www.kinghost.com/dicionário, em 25/07/2008.

${ }^{17}$ Não foram encontradas publicações científicas a respeito destes dois trabalhos.
} 
Além das pesquisas arqueológicas desenvolvidas no Nordeste, temos a dissertação de mestrado de Paulo Bava de Camargo, "Arqueologia das Fortificações Oitocentistas na planície costeira de Cananéia/lguape, SP", defendida em 2002, no Museu de Arqueologia e Etnologia da USP. Esta dissertação fez parte de um programa arqueológico sobre o estabelecimento das populações no Baixo Vale do Ribeira, coordenado pela professora Maria Cristina Mineiro Scatamacchia e envolveu pesquisas de Arqueologia Subaquática.

Utilizando as discussões teóricas envolvidas com a Arqueologia Social e a Arqueologia Crítica e definindo a Arqueologia Histórica como uma Arqueologia que se preocupa com os vestígios de uma sociedade com formação econômico-social mercantilista e capitalista, este autor propôs como objetivos levantar dados, localizar estruturas e compreender o sistema defensivo do litoral paulista, especialmente na região de Cananéia/lguape. Para tanto, foram realizadas análises das fontes documentais, prospecções arqueológicas terrestres e subaquáticas, comparações sobre sistemas defensivos, análises das peças de artilharia etc.

Dessa forma, Camargo apresenta a existência do que define de quatro "subsistemas" ou "sistemas" defensivos do litoral paulista: Paranaguá, Cananéia/Iguape, Santos/São Vicente e São Sebastião/llha Bela, sendo realizada uma comparação prévia entre estes. A partir desta comparação prévia, que teve como foco, principalmente, o tipo de estrutura defensiva e o armamento que elas possuíam, foi concluído que a análise deveria ser realizada entre os subsistemas de Cananéia/lguape e de São Sebastião/llha Bela, porque ambos apresentaram fortificações definidas como "provisórias", ou seja, que não dispunham de construções finalizadas, bem feitas ou bem conservadas. Assim, a análise entre os dois subsistemas foi baseada em discussões que envolviam os seguintes parâmetros: tipos de fortificações, implantação das fortificações, armamentos, tropas e funcionamento (CAMARGO, 2002, p. 31).

Com todos os parâmetros avaliados, Camargo apresentou os seguintes pontos fortificados no subsistema São Sebastião/llha Bela: o Forte Sepetiba, fortificação "provisória", erguida a partir de 1819, que não possui argamassa nas suas muralhas e o Forte da Ponta das Canas que, ao contrário do Forte 
Sepetiba, teria muros sólidos de pedra e cal, emoldurando uma espessa camada de terra batida, porém esta fortificação teve suas obras interrompidas em 1831 (CAMARGO, 2002, p. 69-72).

Os pontos de Cananéia/Iguape apresentados foram: Bateria ou Trincheira de Icapara e Ponta da Trincheira. O primeiro ponto fortificado, segundo as conclusões deste autor, seria um canhão de ferro, de sítio, calibre 12, instalado em algum local do porto de Icapara, mas esta peça não foi localizada; e o segundo, uma fortificação no pontal do norte de Cananéia que teria começado a ser construída em 1822, com a chegada da artilharia à vila (CAMARGO, 2002, p. 75-80).

Sobre esta última fortificação, a qual o mesmo trata com amplitude, pela abundância de documentos escritos, esta passou por reformas e, a partir de 1850, já não teve mais uso militar, servindo como prisão e, até mesmo, enfermaria. O mais importante, no entanto, refere-se à construção dessa obra defensiva: as primeiras fontes escritas determinam a construção de uma "cortina de faxina", ou seja, uma paliçada de madeira ou barricada com cestos. Entretanto, essa fortificação, de acordo com o Corpus documental, teve várias edificações, seja para escapar da erosão das margens do canal onde ela foi implantada, seja para melhorar a eficiência dos equipamentos e, por esse motivo, termos como bateria, trincheira e forte também são utilizados nas fontes escritas. Cabe destacar que no local foram realizadas prospecções, terrestre e subaquática, e escavação para localizar uma peça de artilharia pertencente à fortificação, que estaria submersa na região. O local foi identificado, mas devido às dificuldades encontradas para retirar o canhão, este foi conservado (CAMARGO, 2002, p. 81-130).

A partir da comparação entre os subsistemas, o autor observa que as construções apresentam-se de modo diferente: a fortificação de Sepetiba, como dito, é composta por pedras sem argamassa, e na fortificação da Ponta da Trincheira, não foi localizado nenhum vestígio de construção. Sobre esse fato, Camargo afirma que essas obras defensivas eram trincheiras, fortins, redutos, fortes efêmeros, construídos da noite para o dia, num momento necessário, ou seja, embora muitas vezes planejadas, só teriam sido executadas em situações de máxima tensão. Nesse sentido, essas construções eram compostas de barreiras de cestos cheios de pedra, areia e 
entulho, o que significa que muitas das informações materiais das fortificações foram perdidas porque os cestos não se conservaram ou foram retirados (CAMARGO, 2002, p. 134-135).

No que diz respeito às peças de artilharia, o sistema defensivo de Cananéia/lguape apresentou peças Armstrong, já consideradas ultrapassadas no século XIX, e o de São Sebastião/llha Bela, além destas peças, apresentou canhões Blomefield, os mais modernos no século XIX. As explicações para tal fato são as seguintes: o canal de São Sebastião/llha Bela é mais largo e profundo que o primeiro, além disso, a circulação de mercadorias era mais significativa nessa região e, por fim, a proximidade de São Sebastião com o Rio de Janeiro, pois toda a costa fluminense era protegida, incluindo Paraty e Angra dos Reis (CAMARGO, 2002, p. 136-137), como discutiremos nas páginas a seguir.

De um modo geral, apresentamos alguns pesquisadores e temas tratados na área de Arqueologia Histórica e de maneira mais detalhada, investigações que analisaram o mesmo objeto material que propõe esta dissertação. É importante acrescentarmos que um dos objetivos desta pesquisa é compreender as fontes disponíveis para construir uma, entre tantas possíveis, interpretação das estratégias defensivas da região de Angra dos Reis. Daí a importância de discutir a prática de uma Arqueologia que priorize uma abordagem contextual, que inclui, principalmente, a análise das fontes escritas e materiais. Partimos então para a discussão sobre os possíveis diálogos entre essas fontes. 


\section{Documento escrito e documento material: o diálogo entre as fontes}

Como sabemos, o positivismo privilegiava as fontes escritas de cunho oficial. No entanto, nas últimas décadas, as Ciências Humanas passaram por transformações epistemológicas, sociais e políticas que resultaram em novas abordagens e perspectivas (FUNARI, 2005, p. 5). Dessa forma, os modelos normativos de interpretação da sociedade sofreram críticas variadas e o próprio conceito de fonte se ampliou, elevando à categoria de testemunho histórico qualquer tipo de vestígio do passado (LARA-LÓPEZ, 2005, p. 1).

Mas mesmo com a ampliação ou, como dizem, universalização ${ }^{18}$, do uso de variadas fontes, ainda persiste um problema principal: as fontes não oferecem um aspecto imediato da realidade, pois não são nem janelas escancaradas, como acreditam os positivistas, nem muros que obstruem a visão, como pensam os cépticos (GINZBURG, 2002, p. 44).

Dessa forma, como as fontes são parciais, carregam sentido social ${ }^{19} \mathrm{e}$ apresentam especificidades, o pesquisador deve examiná-las, tentar compreender o seu alcance, respeitar sua natureza. Em outras palavras, por mais que os fatos existam, em qualquer tipo de registro histórico, isso não significa que eles revelam seus significados e relações por si mesmos e independentemente dos procedimentos teóricos (THOMPSON, 1981, p. 37).

A partir dessa breve reflexão pensamos na prática da Arqueologia Histórica, uma área da Arqueologia onde podemos utilizar tanto o documento material, quanto o documento escrito. Mas como agir frente à existência desses dois tipos de fontes?

\footnotetext{
${ }^{18}$ Este assunto foi tratado na disciplina Documentos e Arquivos, oferecida pela FFLCH. Durante o curso, na maioria dos textos utilizados, os autores mostram suas críticas à resistência de muitos historiadores em aceitar determinados tipos de fontes. Estamos no século XXI e ainda encontramos nestes textos científicos o pedido para que se reconheçam determinados objetos como fontes para a pesquisa histórica. Há uma ampliação dos estudos, mas a universalização ainda deve ser discutida. Sobre o assunto consultar, DELMAS, Bruno. Donner a l'image et au son le satatut de l'écrit: pour uno critique diplomatique des documents audiovisuales. Bibliotheque de l'École des Chartes, Paris, t. 161, p. 553-601, juillet-décembre 2003; FALBE-HANSE, Rasmus. The Filmmaker as historian. P. O. V.: a Danish Journal of Film Studies, Aarhus, $n^{\circ}$. 16, December, 2003, LARA LÓPEZ, Emilio Luis. La fotografía como documento historico-artístico y etnográfico: una epistemología. Revista de Antropologia Experimental, Jan, $\mathrm{n}^{\circ} .5$, texto 10, 2005.

${ }^{19}$ No caso das fontes materiais é importante destacar a postura de Hodder, "la cultura material no existe porque si. Alguien la produce. $\mathrm{Y}$ es produzida para algo. Por lo tanto no refleja pasivamente la sociedad". (HODDER, 1994, p. 20).
} 
Assim, quando tratamos das Arqueologias Históricas praticadas no mundo ${ }^{20}$, esse questionamento ainda é recorrente. Ao lidar com esta questão ainda há uma falta de consenso, pois há pesquisadores que defendem as similaridades entre ambas as fontes e há aqueles que defendem suas diferenças. Tais metodologias diversas e o debate em torno disso existe porque a Arqueologia incorpora uma ampla variedade de contextos históricos e geográficos, bem como uma diversidade de tradições históricas e arqueológicas (FUNARI, JONES e HALL, 1999, p. 10).

Em geral, como já dito, entre não poucos pesquisadores, o documento material é visto como uma comprovação do que nos dizem os textos, ou seja, comportam-se dessa forma de maneira submissa às hipóteses formuladas pela fonte escrita (e.g. FLORENZANO, 2003, p. 14). Entretanto, sabe-se que a ocorrência da escrita, de uma cultura literária e do letramento é bastante recente, comparado à experiência humana. Assim, relegar à cultura material um papel secundário é subestimar essa permanente experiência entre as sociedades, pois a totalidade da população humana relaciona-se de alguma forma com a cultura material e até mesmo a escrita pode ser vista por meio de sua materialidade (FRANCISCO, 2007, p. 35).

A questão é: como analisar a cultura material e os documentos escritos? Como enxergá-los? O que a cultura material e a escrita têm a dizer sobre o passado? A análise dos textos é melhor do que a dos artefatos para expressar certos fenômenos, ou vice-versa? (ANDRÉN, 1998, p. 148).

BRUNEAU (1974, p. 2) afirma que a relação entre os documentos escritos e os vestígios materiais é complexa, pois ambos não estão no mesmo nível de abstração. Este autor argumenta que os vestígios materiais contêm informações virtuais, que devem ser traduzidas num enunciado verbal, enquanto que os textos se situam por definição no nível da linguagem. Entre ambos pode haver analogias, mas essa analogia não é identidade absoluta, pois o terreno arqueológico não é um texto. Para ele, vestígios materiais e fontes textuais não apresentam natureza idêntica (BRUNEAU, 1974, p. 3).

Mais recentemente, SMALL (1999, p. 122), ao introduzir o debate sobre o uso dos textos e da Arqueologia na reconstrução social para o campo de

\footnotetext{
${ }^{20}$ Sobre o assunto consultar, ANDRÉN, 1998.
} 
Arqueologia Clássica, afirmou que a corrente relação entre a evidência arqueológica e a evidência textual nesse campo de pesquisa tem limitado a compreensão do passado clássico. Para o mesmo, é importante reconhecer que os registros, arqueológico e documental, são fontes de dados independentes e que foram produzidos em contextos sociais distintos ${ }^{21}$ (SMALL, 1999, p. 135).

Sobre a prática da Arqueologia Histórica americana, ZARANKIN e SENATORE (1996, p. 113-118) afirmam que existem duas posturas mais generalizadas: um primeiro enfoque tem suas bases na análise da evidência documental, que os autores chamam de perspectiva historicista. E o outro, tem suas bases na visão de que as evidências documentais e materiais são corpus de dados distintos.

A perspectiva historicista considera que as evidências arqueológicas e documentais estão ligadas, e cada uma depende da versão da outra. Ou seja, são corpos de dados homogêneos. Dessa forma, os problemas a investigar se definem em uma escala histórica, isto é, são determinados pela resolução da evidência documental. Na maior parte das pesquisas, a análise das fontes se realiza a priori do trabalho arqueológico, gerando a informação relevante a respeito dos problemas definidos no projeto. A evidência arqueológica complementa a informação presente nos documentos escritos. Em outras palavras, ela materializa a evidência documental.

Na segunda perspectiva, a que os autores dão o nome de perspectiva arqueológica, as evidências documentais e materiais são considerados corpus de dados distintos, com status epistemológico diferentes. A qualidade de informação que podem oferecer é determinada pela natureza de cada uma. Neste caso, a informação histórica permite conhecer e definir o contexto histórico geral em qual se insere o problema arqueológico.

Seguindo esta última perspectiva, essa pesquisa não pretende colocar uma evidência frente à outra, pelo contrário, como a fonte material e a fonte

\footnotetext{
${ }^{21}$ Em contrapartida JOHNSON afirma que a evidência documental e material são produtos de um mesmo processo social. Para este autor devemos construir uma arqueologia dos documentos e, em linhas gerias, precisamos abolir as diferenças entre textos e artefatos, pois se cultura material é texto, texto também é cultura material. Nesse sentido, devemos estar atentos à forma como os historiadores trabalham e ao complexo plano de fundo dos documentos, ou seja, como estes foram gerados (JOHNSON, 1999, p. 31-33).
} 
escrita possuem natureza diversa, pretendemos extrair de ambas as fontes informações variadas, levando em conta suas especificidades.

Podemos apresentar, brevemente, uma dessas especificidades, já que os documentos escritos, aqui tratados, são classificados em sua maioria como cartas, ofícios, relatos entre o governo do Rio de Janeiro e a Corte portuguesa e, depois, entre o Governador Militar da Ilha Grande e o Governo Imperial, sobre a necessidade e a manutenção de um sistema defensivo no litoral sul fluminense. Ou seja, são correspondências oficiais.

Sobre a utilização dessas correspondências, GOMES (2004, p. 19) afirma que as mesmas foram instrumentos flexíveis para comunicar todos os tipos de fatos, decisões e mensagens relacionadas com as esferas de atividades administrativas, judiciais, comerciais, políticas, financeiras entre outras. Segundo esta autora, a mensagem epistolar foi transformada em uma forma definitiva na passagem do oral para o escrito, que não somente introduziu uma distância apropriada da comunicação verbal, mas também exigiu formas específicas de composição ${ }^{22}$.

Dessa forma, enquanto consideramos cartas como fontes históricas devemos vê-las como textos produzidos em uma situação dialógica, transmissores de mensagens específicas, definidas por circunstâncias de tempo e espaço. Assim, as cartas são documentos que têm origem em complexos atos de comunicação, onde a função dos personagens pode ser configurada e analisada em caminhos relativos: autor e escrivão, o destinatário e o mensageiro, o autor e o mensageiro, o remetente e o destinatário, entre outros.

Aqui, a preocupação está voltada, principalmente, na relação remetentedestinatário ou autor-receptor, e, neste caso, o primeiro deve expor (sendo este um governador), de um modo geral, uma situação desagradável ao receptor (neste caso o rei), sobre a presença de navios estrangeiros e sobre a prática de contrabando na região de Angra dos Reis. Nesse sentido, devemos levar em consideração que essas correspondências nem sempre foram sinceras e podem ter sido relatadas tempos depois do fato ocorrido. No caso inverso,

${ }^{22}$ De acordo com CONCEIÇÃO (2005, p. 2), "as correspondências oficiais acompanharam as mudanças do contexto em que estavam inseridas - mudanças em questões políticas, econômicas e sociais, ressaltando-se as reformas educacionais e as discussões que acompanharam os teóricos epistolares do século XVIII". 
entre autor-receptor, temos que destacar o discurso oficial e o caráter normativo dos documentos (FUNARI e OLIVEIRA, 2005, p. 35), ou seja, o rei expressou normas que deveriam ser seguidas sobre a defesa, mas isso não significa que o receptor (ou receptores) chegou (ram) a executá-las.

Em ambos os casos não podemos deixar de mencionar aqui uma questão que se refere à autenticidade e à veracidade dos documentos. Há distinção entre esses dois conceitos. Como as correspondências utilizadas neste trabalho são, em sua maioria, documentos de arquivos (extraídos das instituições de arquivo ou de publicações relacionadas com o tema ${ }^{23}$ ), podemos indicar nelas a autenticidade, pois as mesmas exprimem sinais de validação, como assinaturas, carimbos, marcações do tempo. No entanto, isso não significa que estes documentos tenham teor verdadeiro. O pesquisador, nesse sentido, extrai suas informações, mas a autenticidade não está atrelada, necessariamente, à veracidade. Podemos citar o caso de registros de nascimento em cartório: o indivíduo pode nascer em um dia, mas ser registrado em outro.

Entretanto, mesmo com suas especificidades, os documentos escritos ${ }^{24}$, nesta pesquisa, contribuem para uma interpretação da história defensiva de Angra dos Reis, pois, a partir de suas informações, traçamos um contexto histórico sobre as estratégias de defesa da região. Vale ainda destacar que, além da análise destes documentos primários, serão extraídas informações de pesquisas de historiadores locais ${ }^{25}$.

$E$, no que diz respeito à fonte material, sua própria existência pode indicar, em primeira mão, aspectos relacionados à sua materialidade, como por exemplo, matéria-prima, técnica de fabricação, sinais de uso, indicações sobre sua duração. Mas não é só isso. A existência dessas estruturas de pedra,

\footnotetext{
${ }^{23}$ As etapas de levantamento documental e iconográfico contaram com as seguintes atividades: localização e análise de documentos e obras sobre a região de Angra dos Reis, em bibliotecas e arquivos; sistematização do material coletado; análise das informações obtidas; análise comparativa com resultados obtidos por outros pesquisadores.

${ }^{24}$ Aqui vale destacar a postura de MORELAND, que entende os documentos escritos como produtos da criatividade humana, criados e distribuídos dentro das relações sociais. Nas palavras deste autor, "Archaeologists must recognise that people in the historical past wove or constructed their identities, not just from the objects they created, possessed and lived within, but through texts as well". (2001, p. 34)

${ }^{25}$ Esses estudos são definidos como fontes históricas secundárias, ou seja, foram produzidos por pessoas que não presenciaram os acontecimentos do passado. No entanto, estes trabalhos baseiam-se nas fontes primárias, produzidas por observadores diretos ou contemporâneos dos acontecimentos relatados (ORSER, 2000, p. 34).
} 
escondidas na natureza, também pode indicar que elas tinham um papel importante na defesa da região. Por esse motivo é necessário compreender seu contexto histórico e também geográfico, porque as fontes materiais podem indicar sinais ligados à sua função e significado (HODDER, 1994, p. 26).

Aqui vale dizer que essas estruturas nem sempre podiam estar em funcionamento, ou seja, elas poderiam ser usadas apenas em caráter emergencial, como no litoral norte paulista. No entanto, mesmo nessas condições, elas podem ter participado de um plano estratégico para defender a região, talvez não com o objetivo de destruir os navios indesejáveis, mas com a intenção de evitar o desembarque de invasores eventuais. Isso significa que a sua própria existência aponta para a necessidade de artilharia, de pessoas disponíveis para sua construção, para sua manutenção e guarda.

Dessa forma, temos o objeto material com duplo significado: é produto da ação humana, articulado através das relações sociais e, ao mesmo tempo, é um dos sentidos nos quais as relações sociais são construídas, produzidas e transformadas. (MORELAND, 2001, p. 34). Nesse sentido, as estruturas defensivas apresentadas podem indicar aspectos, além dos materiais, também relacionados ao controle militar e uma variedade de prática a eles associados (FUNARI e OLIVEIRA, 2005, p. 56).

A identificação de todas as características contextuais das estruturas defensivas nos leva a mais um tipo de fonte que contribui para o conhecimento histórico: a paisagem (BORNAL, 2008, p. 10). Entretanto, não pretendemos observar apenas as características físicas da paisagem onde as estruturas foram implantadas. Pelo contrário, o que se pretende é encarar a paisagem como um espaço que sofre, ainda hoje, constantes transformações, sobretudo pelo homem. Isso significa que essa fonte não é estática, o que a diferencia de um local onde podemos pensar apenas nas características físicas. Nas palavras de Meneses sobre a os estudos que contemplam a paisagem,

"A paisagem oferece pistas materiais que permitem perceber seu caráter histórico, são esses traços fósseis que conduzem ao entendimento da formação geomorfológica e social da paisagem contemporânea e de suas sucessivas fisionomias anteriores ao longo do tempo".

(MENESES Apud BORNAL, 2008, p. 10) 
Longe de se propor aqui uma pesquisa que aborde com amplitude a perspectiva da Arqueologia da Paisagem, queremos apenas expressar a sua importância numa abordagem contextualista, pois, as "paisagens defensivas" foram escolhidas para abrigar estruturas que garantiriam a defesa do território colonial. Para tanto, as mesmas precisariam apresentar características necessárias para esta escolha. Dessa forma, mais uma vez demonstramos que essa relação do homem com o meio levou às alterações no espaço, acarretando paisagens culturalmente alteradas. Assim, entendemos que essas paisagens históricas não existem de forma isolada, mas sugerem como as pessoas pensavam e atuavam sobre o espaço, concedendo uma dimensão simbólica, denominada paisagem social (AMENOMORI, 2005, p. 11).

Para finalizar, a partir das idéias expostas anteriormente, percebemos que é possível dialogar com todas as fontes, na medida em que respeitamos suas diferenças e compreendemos seus alcances distintos. Nesse sentido, o primeiro passo para compreender melhor o papel dessas estruturas, como dito, é definir seu contexto histórico. Para isso, precisamos analisar todos os dados disponíveis ${ }^{26}$ (HODDER, 1986, p. 139). Comecemos, então, por uma discussão sobre a necessidade de haver estratégias defensivas para o litoral sul fluminense, região vulnerável a invasões estrangeiras desde os primeiros anos de colonização portuguesa.

${ }^{26}$ O conjunto de dados disponíveis é resultado das etapas de levantamento documental que ocorreram nas cidades do Rio de Janeiro e de Angra dos Reis, bem como das duas etapas de campo, executadas até o momento. 


\section{Defesa e estratégia na costa sul do litoral fluminense}

As primeiras informações da presença dos piratas e corsários ${ }^{27}$ na costa brasileira remontam os primeiros anos de colonização, quando se espalhara a notícia das qualidades corantes do pau-brasil e os lucros que se obtinha através de seu comércio (MELLO, 1987, p. 27). Dessa forma, o litoral brasileiro, desde os primórdios da sua exploração, foi considerado altamente vulnerável a invasões estrangeiras.

Nesse contexto encontra-se o litoral sul fluminense, uma região "periférica", localizada entre dois grandes centros que foram fortificados, Rio de Janeiro e Santos ${ }^{28}$, e que, como veremos adiante, até o século XVIII não tinha sua jurisdição bem definida. Entretanto, mesmo nessas condições, a partir do século XVI, essa área já estava envolvida nos conflitos entre portugueses e franceses, possuía uma bem organizada rede de caminhos indígenas que ligavam o interior ao litoral e já era visitada por navios estrangeiros, que cruzavam o mar desde Cabo Frio $^{29}$ até a llha Grande (FREITAS, 1986, p. 304).

Podemos propor como uma das primeiras estratégias de defesa no litoral do Rio de Janeiro, sobretudo no litoral sul fluminense, em meados do século XVII, a atitude de Martim de Sá que, para a vigilância constante, fez o deslocamento de aldeias de índios ${ }^{30}$ para Cabo Frio e para a Baía de Illha

\footnotetext{
${ }^{27}$ É necessário distinguir as práticas de piratas e corsários. A primeira delas refere-se às ações de saque e pilhagem, função prioritária da atividade pirática, onde a violência e a agressão eram os meios de sua realização. Já a segunda refere-se às ações oficiais, realizadas sob ordens ou com autorização de um determinado Estado, onde o praticante jamais poderia ser punido com morte, devendo ser tratado como um elemento beligerante oficial (DURAN, 2004, p. 1-12).

${ }^{28}$ Sobre as fortificações do Rio de Janeiro consultar, FERREZ, 1972. Para informações sobre as obras defensivas de Santos, consultar MORI, 2003 e o site http://www.novomilenio.inf.br/santos/h0300a4.htm.

${ }^{29}$ No início do século XVII, holandeses e franceses já hostilizavam nosso litoral, o invadindo em vários pontos, a fim de carregarem pau-brasil. De acordo com Freitas, “(...) das invasões mais difíceis de serem repelidas, a de Cabo Frio, pelos franceses, ali estabelecidos longo tempo, onde construíram um forte e um armazém para depósito de madeira. Cumprindo ordens do Reino, Martim de Sá (...) determinou ao (...) Capitão Constantino de Menelau, (...), sua ida a Cabo Frio para expulsar os piratas ali encontrados e fundar uma povoação" (FREITAS, 1986, p. 304-305).

${ }^{30}$ De um modo geral, todos dependiam dos índios para garantir a defesa das vilas e de suas propriedades e, além disso, estes eram importantes na penetração do interior do território e como intérpretes no contato com outros povos. Nesse sentido, foram muito comuns os chamados "descimentos", ou seja, o deslocamento de aldeias inteiras para as proximidades dos estabelecimentos portugueses (OLIVEIRA, 2002, p. 85).
} 
Grande $^{31}$, de forma a garantir a defesa (OLIVEIRA, 2003, p. 2), como nos mostra o documento a seguir,

\begin{abstract}
"(...) trouxe da capitania do Espírito Santo os casais de índiosque V. Mg. me mandou para situar na Ilha Grande os quais tenho já situados e a minha custa comprei mantimentos e o mais necessário para seu sustento na dita aldeia (...) $\mathrm{E}$ juntamente situei mais daqui para São Vicente nesta costa duas aldeias de outro gentio que mandei descer para a defesa dela e agora estou de caminho para o Cabo Frio a situar outra aldeia das duas que V. Mg. Mandou (grifo meu) (...)".
\end{abstract}

(Carta de Martim de Sá ao rei Felipe II, datada de 20 de dezembro de 1619, Apud OLIVEIRA, 2003, p. 2)

No início do século XVIII, como a exploração aurífera na região das Minas Gerais intensificou o trânsito dos corsários e piratas e o escoamento ilegal de ouro, outra atitude para evitar os "descaminhos" foi tomada: a criação, em Paraty, da Casa dos Quintos ${ }^{32}$, também chamada de Casa dos Registros ou simplesmente Barreira, em 1703. Neste local eram examinados os passageiros e a quantidade de ouro que traziam, em pó ou em barra, o que não conseguiu evitar a prática de contrabando ${ }^{33}$.

\footnotetext{
${ }^{31}$ Sobre a ocupação da Baía da llha Grande há relatos de cronistas em aldeias indígenas do Rio de Janeiro (André Thevet, 1556; Jean de Lery, 1552; Hand Staden, 1557). Tais relatos limitam-se às áreas da Baía da Guanabara e da região denominada Iperoig, ou seja, a baía da Ilha Grande (Iperoig significa água do tubarão, devido a grande quantidade na região). Além disso, há as fontes jesuítas, de Manuel da Nóbrega e de José de Anchieta, que visitaram por dois meses as aldeias de Iperoig, pouco tempo antes da investida portuguesa (OLIVEIRA, 2002, p. 52). Entretanto, faz-se necessário aqui destacar a visão de BORGES (1988, p. 14), que afirma a existência de núcleos portugueses na llha Grande no século XVII. Mas, segundo OLIVEIRA (2004, p. 6), até as duas primeiras décadas do século XVIII não parece existir na Ilha Grande ocupação portuguesa efetiva. Apenas em Angra dos Reis e Paraty encontravamse núcleos portugueses efetivamente implantados.

${ }^{32}$ Sobre a Casa dos Quintos, "foi criada por carta régia de 9 de março de 1703, que mandou extinguir as oficinas de Guaratinguetá e Taubaté, e estabelecer as de Santos e Paraty. Seu primeiro provedor foi Carlos Pedroso da Silveira, um dos pioneiros da descoberta do ouro em Minas Gerais. Para instalá-la foi usado o material e equipamento das oficinas de Taubaté e Guaratinguetá". Informações retiradas do site: http://www.fazenda.receita.gov/memorias. Consultado em 26/06/2008.

${ }^{33}$ De acordo com Amaral e Gurgel, "uma das maneiras mais usadas pelos "tropeiros" para fugir ao pagamento do tributo real era conhecida por "mato para que te quero". Quando a "tropa" aproximava-se da BARREIRA DO REGISTRO, que ficava no alto da serra, já em território paratiense, grande parte do ouro era retirada dos alforges e dada a um homem de confiança do "tropeiro", que entrava pelo mato 200 braças antes e saía 200 depois, burlando assim o fisco" (GURGEL e AMARAL, 1973, p. 40). Cabe ainda destacar que em 1714 foram descobertos os primeiros diamantes e deles se guardaram segredo por longo tempo. Dessa forma, o ouro em pó desde muito se tornava o principal motivo do comércio ilícito que a cada dia mais se intensificava. Segundo FREITAS (1986, p. 298), estimou-se em dez mil arrobas o ouro contrabandeado neste período, assim, não seria de todo absurdo que os corsários,
} 
Até mesmo depois da criação do chamado "Caminho Novo", tratado adiante, que reduziu o fluxo pelo "Caminho Velho", foram aproveitados e abertos novos caminhos que ligavam Minas Gerais aos portos do litoral sul fluminense, que serviram para o contrabando. Essa prática tornou-se tão habitual que havia um apoio, por parte dos moradores, aos contrabandistas, através da venda irregular de mantimentos aos estrangeiros (VASCONCELLOS, 2006, p. 42).

CAPAZ (1996, p. 99-100) afirma que já em 1694, quando começaram a intensificar os corsos entre Cabo Frio e Santos, os corsários freqüentavam a Ilha Grande, onde encontravam abrigo e com cujos habitantes mantinham relações de comércio. Conforme mostra este mesmo autor, citando rroger $^{34}$, integrante da esquadra do De Gennes,

"A Ilha Grande, diz Froger, tem cerca de 18 léguas de
circunferência. O governador do Rio de Janeiro
proibiu os habitantes de nos venderem qualquer
coisa, mas ele nos fornecem tudo o que queríamos.
Os angrenses têm suas casas nas montanhas e assim
como os paulistas manifestam grande desejo de se
libertarem (grifo meu)".

(FROGER Apud CAPAZ, 1996, p. 121)

Dessa forma, a ameaça de invasão estrangeira e o conseqüente contrabando de ouro e de escravos na região que abrange Itaguaí, Sepetiba, Ilha Grande, Angra dos Reis e Paraty, exigiram constantes esforços das autoridades da cidade do Rio de Janeiro para sua defesa. Já mesmo no século XVII, enquanto Portugal vivenciava o período de restauração do trono português, com a contratação de profissionais estrangeiros para a defesa de seu reino e regiões conquistadas ${ }^{35}$, os documentos de época apontam que o litoral sul fluminense era considerado vulnerável pelo governo desta cidade. A citar como exemplo,

"Entre a llha grande, e terra firme esta hum dilatado Porto onde os navios estrangeiros, dam fundo, (...), defronte desta Ilha estão duas villas a saber ade

operando em toda a costa, fossem tais embarcações, sempre dispostas a revidar as ordens recebidas para se afastarem dos nossos mares.

${ }^{34}$ Relation d'un voyage fait en 1695,1696 et 1697 aux côtes d'Afrique, détroit de Magellan, Brésil, Cayenne et isles Antilles, par une escadre des vaisseaux du roy, commandée par M. De Gennes, Paris, quay de I'Horloge, 1698, Amsterdam, 1699, 1702, L'Honoré et Chatelain, 1715.

${ }^{35}$ Sobre o assunto consultar TAVARES, 2000; BUENO, 2001. 
Angra dos Reis eade Peraty (...) do Governo de São Paulo, que dista daquella cidade quinze dias dejornada, edesta quatro, advertindo que a Ilha Grande he desabitada, eosmoradores davilla de Angra dos Reis são todos pobres, e sem pocebilidades para fazerem negociação nesta villa por ser desta jurisdição (...) ficando por este modo exposto este Governo ao injusto labeo de se fazerem negociasões pella Ilha Grande, que seconcedera toda por ser fora daminha jurisdição (...)" (grifo meu).

(Carta do Governador do Rio de Janeiro, Francisco Souto Mayor ao Rei, 18/01/1645, Arquivo Colonial, cx. 2, n. ${ }^{\circ} 47$ )

Além disso, há uma grande relação de correspondência dos governadores do Rio de Janeiro, relatando perseguições a navios piratas franceses e a necessidade de evitar que os mesmos se hospedassem na Ilha Grande $^{36}$. Cabe ressaltar ainda que nos princípios do século XVIII a administração do Rio de Janeiro não alcançava maior parte das terras do litoral sul fluminense, sendo estas subordinadas a Capitania de São Paulo ${ }^{37}$.

Enquanto a cidade do Rio de Janeiro se defendia, no litoral sul fluminense, em meados deste século, também se multiplicam as guardas para sua defesa, em todos os caminhos para o interior e para São Paulo, o que parece não ter intimidado o contrabando, pois,

"(...) fechados os caminhos para a Baía e para o Rio de Janeiro, vigiados rigorosamente os portos de Angra dos Reis e Paraty e atentos os "Registros", volveram os contrabandistas para o caminho de Itaguaí".

(FREITAS, 1986, p. 298)

É importante destacar ainda que, espalhadas pelo litoral fluminense, havia as feitorias baleeiras. Essas armações de baleias sempre se

\footnotetext{
${ }^{36}$ Nas palavras de Mello, "registra a história um grande número de corsários (...) que surgiram em nossa costa, ora traficando escravos, ora contrabandeando o pau-brasil (...). No sul, seus lugares preferidos para a espreita eram as ilhas da Marambaia, dos Porcos, Grande, São Sebastião, Santa Catarina (...)" (MELLO, 1987, p. 37). Este autor faz uma relação da correspondência dos governadores, que comenta ser nem sempre sinceros, do Rio de Janeiro de 1685 até 1733. Para mais informações, consultar MELLO, 1987, p. 67-71.

${ }^{37}$ Segundo Mello, "no governo de Arthur Sá é Menezes, de 1697 a 1700, houvera dúvida sobre a correição das vilas de Angra dos Reis, Paraty, Ubatuba e São Sebastião. Ouvido o Conselho Ultramarino, coube ao Rio de Janeiro a jurisdição dessas localidades. A Carta-Régia de 1709, pela qual São Paulo se torna independente, modifica esta situação, e as vilas de Paraty, Ubatuba e São Sebastião retornam à jurisdição de São Paulo. Entre 1725 e 1726, respectivamente, Paraty e Ilha Grande voltam a pertencer ao Rio de Janeiro, por insistência de Luís Vahia Monteiro, que alegava não poder dar cabo da pirataria e contrabando do ouro, se não Ihe fossem adjudicadas essas terras (...)" (MELLO, 1987, p. 106).
} 
estabeleciam em entradas de baía, enseadas de fácil acesso, próximas às fortificações, de forma a ter proteção dos ataques de navios estrangeiros (OLIVEIRA, 2003, p. 3). Na região sul do litoral do Rio de Janeiro, ELLIS (1968, p. 48), indica que na Ilha da Gipóia, próxima à Angra dos Reis e à entrada da Ribeira, foi estabelecida uma feitoria baleeira ${ }^{38}$.

No início do século XIX, passadas as necessidades de se proteger a região do desembarque ilegal de ouro, as fortificações e vigias instaladas no século anterior encontravam-se abandonadas, segundo documentos das Câmaras de Paraty e Angra dos Reis. No entanto, com a Guerra da Cisplatina e com a intensificação da produção cafeeira, que revitalizava o tráfico de escravos, novas medidas foram tomadas em relação à defesa da baía de llha Grande, estabelecendo-se mais baterias de terra, reforçando as já existentes, aos quartéis e fortes (OLIVEIRA, 2003, p. 4).

CAPAZ (1996, p. 165) afirma que nas primeiras décadas do século XIX, já que o governo argentino permitiu que os contrabandistas praticassem o corso, a presença desses corsários, na faixa litorânea entre o Rio de Janeiro e Santos, causou sérios transtornos à navegação comercial da região, a ponto de torná-la quase impraticável. Nas palavras deste autor,

"A falta de um sistema de proteção eficaz, motivada pela ausência de nossos barcos de guerra, aliada à grande mobilidade dos corsos, afeitos ao jogo de ocultar-se para atacar de surpresa, que a geografia litorânea facilitava, causaram um certo pânico nos primeiros tempos de guerrilha marítima".

(CAPAZ, 1996, p. 165)

Apesar de este autor afirmar sobre a falta de um sistema de proteção eficaz, BARRETO (1958, p. 216-218), aponta, no litoral sul fluminense, vários fortes e baterias construídas nos períodos de mudança entre Brasil Colônia e Brasil Império, a citar como exemplos: em Itaguaí, Bateria da Foz do Itaguaí (1818); em Paraty, Forte da Ilha das Bexigas (1818), Forte do Iticopé (em 1822 foi ampliado), Forte da Ponta Grossa (em 1822 foi ampliado), Forte do Defensor Perpétuo (1822), Bateria do Quartel (1822) e, em Mangaratiba, Bateria do Pouso-Triste (1822). Já, em Angra dos Reis, este autor cita a

\footnotetext{
${ }^{38}$ De acordo com Ellis (1968, p. 48), esta construção pode ser referente à da llha das Baleias, no século XVII ou a que estabeleceu Brás de Pina, em meados do século XVIII.
} 
construção do Forte de São Bento, Forte do Carmo e Forte do Leme (em Ponta de Leste), sendo que, segundo o mesmo, estavam em funcionamento no ano de 1838 (como disse no início, já sabemos que a data exata de construção do Forte do Leme é 1908 e não 1838).

No entanto, não é intenção desta pesquisa procurar compreender todo o sistema defensivo formado no litoral sul fluminense. O objetivo é compreender as estratégias de defesa entre Piraquara, Angra dos Reis e Ponta Leste, pois os resultados das pesquisas arqueológicas em Piraquara demonstram que o sistema defensivo dessa área não contou com grandes construções, mas sim, com baterias e pontos de observação espalhados pela região.

Em geral, quando encontramos pesquisas sobre fortificações, estas dão ênfase à visão histórica e arquitetônica, e, além disso, são voltadas para os estudos dos grandes fortes espalhados pelo Brasil. Mas ao nos referirmos a um sistema defensivo nas enseadas próximas a Angra dos Reis, ao contrário de algumas regiões, essas tiveram suas estratégias de defesa apoiadas em construções de pequeno porte. Ainda vale esclarecer que essas pequenas estruturas, construídas com poucos recursos materiais, de duração efêmera e eficácia duvidosa, podem contribuir para a Arqueologia da mesma forma que as grandes construções defensivas, pois, em alguns casos, os fortes e fortalezas não funcionaram sem o apoio dos redutos (CAMARGO, 2002, p. 13).

Dessa forma, apresentamos algumas informações sobre a necessidade de defender o litoral sul fluminense. A partir daí, no segundo capítulo, serão tratadas questões mais específicas, ligadas ao histórico econômico da cidade de Angra dos Reis, a interpretação de sua defesa e os resultados do Projeto "Área Arqueológica de Piraquara". 


\section{CAPÍTULO II}

\section{ARQUEOLOGIA DO SISTEMA DEFENSIVO DE ANGRA DOS REIS}




\section{Aspectos econômicos de Angra dos Reis entre os séculos XVI e XIX}

Angra dos Reis $^{39}$ foi uma das primeiras regiões visitadas pelos portugueses, no que viria ser a costa sul do Rio de Janeiro. Constituída por uma estreita porção de terra, cercada pela Serra do Mar e a Baía de Ilha Grande, Angra foi visitada pelos colonizadores portugueses em 1502, tendo à frente da expedição, André Gonçalves.

Em 1556, a região foi ocupada pelos filhos do capitão-mor da Capitania de São Vicente, Antônio de Oliveira. Em 1560, essa localidade foi elevada à condição de povoado, ocupando hoje o território conhecido como Vila Velha, em frente à Ilha da Gipóia. Progredindo consideravelmente este povoado, em 1593, por Carta-Régia de Dom Felipe I de Portugal e II de Espanha, foi elevada à condição de Paróquia, sob a invocação dos Reis Magos e, em 1608, a povoação tornou-se vila ${ }^{40}$ (LIMA, 1974, p. 82). A mudança estava associada, possivelmente, a sua localização estratégica, visto que estava no meio da rota marítima que ligava São Vicente a São Sebastião do Rio de Janeiro (VASCONCELLOS, 2006, p. 39). Por volta de 1624, o povoado deslocou-se da Vila Velha, primeiro núcleo de ocupação, para o atual sítio, em frente à Ilha Grande $^{41}$.

Nas primeiras décadas do século XVIII, a atividade econômica que prevalecia era a pesca da baleia ${ }^{42}$. Havia armações em Búzios (Cabo Frio), São Domingos (Niterói), na Ilha Grande, em São Sebastião, em Bertioga e em Santos, além de outras (CAPAZ, 1996, p. 97). Porém, neste mesmo século a

\footnotetext{
${ }^{39}$ Segundo Lima, "todo o continente e ilhas adjacentes que formavam a imensa Paróquia eram (...) conhecidos por Ilha Grande, daí o engano da suposição de muitos, ser atualmente, Angra dos Reis e Ilha Grande, a mesma cousa" (LIMA, 1974, p. 133).

${ }^{40}$ Vale aqui destacar que, neste momento, a vila também era chamada de Nossa Senhora da Conceição da Ilha Grande. E, somente em 1835, quando foi elevada à categoria de cidade, recebeu o título de Angra dos Reis (LIMA, 1974, p. 87).

${ }^{41}$ Segundo Vasconcellos, "este fato recebeu duas versões. A primeira considerou que o deslocamento foi resultado do assassinato do vigário por um morador, quando o prelado do Rio de Janeiro suspendeu a nomeação de outro pároco, enquanto existissem, na vila, descendentes do assassino; e por isso os moradores decidiram ocupar outro local. Já a segunda versão defende que, antes do episódio, o novo sítio já vinha sendo ocupado, em função das vantagens que apresentava como água em abundância, em contraposição aos mangues e lagoas, que incomodavam os moradores da vila" (VASCONCELLOS, 2006, p. 39).

42 Da baleia usava-se a carne salgada para alimento, o óleo para a iluminação, a impermeabilização de barcos e como liga na argamassa usada na construção civil (CAPAZ, 1996, p. 97).
} 
descoberta do ouro na região das Minas Gerais causou uma grande modificação no ritmo da vida de toda colônia, inicialmente visível para aquelas regiões que diretamente serviram-Ihe de acesso, tais como Paraty e o restante do litoral sul fluminense (VASCONCELLOS, 2006, p. 40). Conforme destaca Capaz,

"Na travessia do século 17 para o 18, a região da llha Grande viveu um período de grande fastígio econômico. Com a descoberta do ouro nas Gerais, intensificou-se o trânsito de aventureiros que entravam pelo sertão em busca de fortuna; e corsários passaram a rondar a costa para saquear embarcações desprotegidas".

(CAPAZ, 1996, p. 98)

Como dito, nos anos que se seguiram, houve uma corrida do ouro de todas as partes do território e de fora do continente, o que foi inicialmente estimulado pela Coroa portuguesa, entusiasmada com a fonte de riqueza descoberta (SOUZA, 1994, p. 33). Nesta época, o caminho marítimo-terrestre por Paraty, também chamado "Caminho Velho" 43 , "Caminho dos Guayanases" ou "Estrada da Serra", era a única via de penetração que ligava São Paulo e Rio de Janeiro às zonas das minas recém-descobertas.

Pelo "Caminho Velho", ia-se do Rio de Janeiro, por mar, até Paraty. De lá, seguia-se por terra até Taubaté, onde era vencida a Serra do Facão. De Taubaté, chegava-se a Pindamonhangaba, Guaratinguetá, até as roças de Garcia Rodrigues, e finalmente ao Rio das Velhas (ANTONIL, \{1711\} 1982, p. 184). Cabe aqui destacar que este movimento acabou dinamizando Paraty e que essa agitação também beneficiou a Vila de Angra dos Reis, para onde foram os "descaminhos do ouro", pois,

"A partir de Angra dos Reis, desde o início do século XVIII, subiam exploradores da Serra do Mar, provavelmente buscando alternativas para a saída do ouro proveniente das Minas. Podemos supor, assim, que por essa época o contrabando permitiu o sustento de muitas famílias e povoações angrenses".

(MACHADO Apud VASCONCELLOS, 2006, p. 40)

\footnotetext{
${ }^{43}$ Conforme Gurgel e Amaral "antes de 1695, a Estrada da Serra era palmilhada apenas por paulistas e paratienses, a cavalo ou a pé, num bisonho comércio de trocas de produtos agrícolas próprios de cada região. Mas depois da descoberta do ouro nas Gerais, a velha vereda (...), também chamada Estrada da Serra do Facão, e que era conhecida (...) como melhor caminho para as Minas Gerais (...) até que por diligência de Garcia Rodrigues Pais Leme se descobrisse o caminho pela Serra dos Órgãos" (GURGEL e AMARAL, 1973, p. 4142).
} 
Dessa forma, o constante risco de contrabando ${ }^{44}$, principalmente realizado no percurso marítimo do "Caminho Velho", a aspereza e a longa duração da viagem, levaram o governo metropolitano a incentivar a abertura de outro percurso que fosse somente terrestre entre o Rio de Janeiro e Minas Gerais, o chamado "Caminho Novo" ${ }^{45}$. Assim, o governo propiciou seu povoamento, através do oferecimento de sesmarias, títulos e outros privilégios, facilitando o transporte de víveres e evitando os riscos das viagens dos quintos do ouro por mar (SOUZA, 1994, p. 33).

A construção do "Caminho Novo" diminuiu o trânsito existente no porto de Paraty e, indiretamente, no de Angra dos Reis. A partir da segunda metade do século XVIII, por volta de 1756 , os paratienses e o restante da região começaram a sentir uma queda em suas atividades comerciais, embora o novo caminho para as Minas ainda estivesse incompleto (GURGEL e AMARAL, 1973, p. 47).

Entretanto, a centralização do abastecimento das Minas pelo porto do Rio de Janeiro e pelo "Caminho Novo" fez com que a lavoura canavieira se espalhasse do recôncavo da Guanabara para as planícies de Campos e Cabo Frio. E, de acordo com Souza,

"Enquanto a região dos Campos de Goitacazes, ao norte
da província, tornou-se grande produtora de açúcar, (...),
o sul da província, Ilha Grande e principalmente Paraty,
tornou-se (...) centro produtor de aguardente, (...) que

${ }^{44} \mathrm{O}$ pretexto sempre alegado pelos comandantes dos navios arribados eram as aguadas e refrescos; aqueles reabastecimentos de água nos navios, geralmente com reservatórios vazios ou com água em putrefação. Os refrescos consistiam na aquisição de alimentos (peixe, legumes, frutas, abundantes em terra). Com estas justificativas, entregavam-se a venda (contrabando) do que traziam, manufaturados em geral, e embarcavam pau-brasil, ouro, diamantes, açúcar, animais exóticos (FREITAS, 1986, p. 302). E, sobre o contrabando francês, por exemplo, "o interesse dos corsários franceses pela Ilha Grande (...), residia no fato de ser esta vizinha a Paraty, porto marítimo de escoamento de ouro (...); a falta total de fortificações e contingentes de tropas; abundância de lenha e água, frutos cítricos, etc. O porto do Rio de Janeiro, pela sua situação geográfica, (...) não apresentava (...) segurança (...). Este era também o motivo por que tanto os ingleses como franceses, dependendo do seu poderio naval e fogo, preferiam a llha Grande para se refrescarem, pois a geografia desta apresentava possibilidade de fuga" (MELLO, 1987, p. 51).

${ }^{45}$ Segundo Souza, "Garcia Rodrigues Pais deve ter iniciado os trabalhos de abertura do "Caminho Novo" nos fins de 1698. Em 1701, a picada já estava aberta (...). Melhorias feitas por Bernardo Soares de Proença ainda encurtaram-no de quatro dias (...). O caminho paulista demorava dois meses, o "Caminho Velho" (...) quarenta e três dias, e o "Caminho Novo" dezessete e depois doze dias" (SOUZA, 1994, p. 33-34). 
ocupou lugar de destaque no quadro comercial de então ${ }^{46 "}$.

(SOUZA, 1994, p. 38)

Essas mudanças ofereceram para Angra dos Reis novas possibilidades de atividades econômicas, suavizando os reflexos à economia local, decorrentes da crise da mineração. No final do século XVIII, o cultivo de anil ${ }^{47}$ disseminou-se, o movimento portuário dinamizou-se, antigas atividades se ampliaram e novas surgiram $^{48}$ (MACHADO Apud VASCONCELLOS, 2006, p. 42). No entanto, a produção mais significativa foi a de aguardente, absorvendo, inclusive, o cultivo de cana-de-açúcar de Angra e de Paraty.

Com a expansão cafeeira na região, nos primeiros anos do século XIX, 0 centro de atividade econômica se deslocou de Paraty para Angra dos Reis. Esse deslocamento ocorreu não somente pelas vantagens do porto de Angra dos Reis, pois este era mais profundo e livre de assoreamento, mas, sobretudo, pela existência de pequenos embarcadouros naturais, tais como Bracuí, Jurumim, Frade, Mabucaba, entre outros ${ }^{49}$ (VASCONCELLOS, 2006, p. 44).

Além disso, outro fator que favoreceu o escoamento de café do Vale do Paraíba pelo litoral sul fluminense foi a abertura e a melhoria das estradas ${ }^{50}$, 0 que deve ter ocorrido entre os fins do século XVIII e a primeira metade do século XIX, adicionalmente, como portas de saída para o café dessa região,

\footnotetext{
${ }^{46}$ O crescimento da indústria açucareira foi notável. Nesse período, predominavam os engenhos e engenhocas no recôncavo da baía de Guanabara, ocorrendo em menor quantidade nas zonas da llha Grande, de Cabo Frio e nos Campos de Goitacazes. Entretanto, foi nesta última área que a indústria açucareira se desenvolveu de modo mais sensível (MENDES Apud BRUNO, 1959, p. 27-28).

${ }^{47}$ Sua importância foi tanta que uma das praias do atual centro de Angra recebeu seu nome, a Praia do Anil. No entanto, seu cultivo perdeu importância em princípios do século XIX (VASCONCELLOS, 2006, p. 42).

${ }^{48}$ Em Angra dos Reis verificou-se, além da produção de aguardente, cultivos de arroz, café, anil, cacau, algodão, legumes, laranja, banana e mandioca para a fabricação de farinha (ARAÚJO, \{1820\} 1945, p. 68).

${ }^{49}$ Conforme Lima, "seus famosos portos Jurumim, Ariró, Itanema, Frade, Mambucaba, Abraão e Sítio Forte, eram verdadeiros empórios comerciais. Para eles convergiam os produtos de sua próspera lavoura, assim como do interior das Províncias do Rio de Janeiro, São Paulo e Minas, que, em troca, levavam suas tropas carregadas de produtos que importavam para consumo, muito principalmente fazendas, vinho, aguardente, ferragens, peixe e sal" (LIMA, 1974, p. 118).

${ }^{50}$ Segundo Machado, "pelo vale do Ariró, além da "estrada do barro", à margem da qual surgiu, na primeira metade do século XIX, Santo Antônio do Capivari (hoje Lídice), no caminho em direção a São João Marcos, passavam as estradas do Caramujo (em direção a Bananal), e a "estrada João de Oliveira", que desembocava na foz do Jurumim. Pelo vale do Bracuí, outro caminho subia a serra em direção a Bananal. E pelo Vale do Mambucaba atravessava a Serra da Bocaina em direção a Areias" (MACHADO Apud VASCONCELLOS, 2006, p. 44).
} 
desenvolveram-se os portos localizados no golfo angrense (MOTTA, 1999, p. $51)$.

Nesse sentido, o porto de Angra dos Reis tornou-se de grande importância. Na localidade havia o predomínio de marinheiros que moravam nos arredores, e que também se ocupavam da lavoura. Concomitantemente, entravam pelos portos do litoral sul fluminense, artigos de primeira necessidade e de luxo (LUCCOCK, \{1820\} 1975, p. 402).

A respeito do café, este provinha de algumas plantações locais, que foram vistas por viajantes que passaram pela região, tais como KIDDER (\{1845\}, 1980, p. 183) e POHL (\{1832\}, 1976 p. 69). Além disso, Angra dos Reis recebia a produção do Vale do Paraíba fluminense, de regiões como Barra Mansa, Rio Claro e Capivari e, do vale paulista, vinham sacas de café provenientes de Bananal, Areias e Cunha, sendo que o escoamento foi garantido por armazéns instalados ao longo do litoral (VASCONCELLOS, 2006, p.48).

Assim, em parte do século XIX, a população do litoral sul fluminense esteve voltada para a produção de café e de alimentos e, principalmente, para o movimento de seus portos ${ }^{51}$, o que estimulou a economia. Vale destacar que a atividade portuária existente em Angra dos Reis foi comum em outras localidades, como em Ubatuba, no litoral norte paulista.

Dessa forma, os gêneros alimentícios cultivados nas terras angrenses eram consumidos pelos próprios agricultores e vendidos para os armazéns locais. O café e a aguardente, além de serem consumidos pela população, também eram comercializados no Rio de Janeiro. Além da pesca, atividade complementar à dieta, a população local contava com a atividade do transporte do café (VASCONCELLOS, 2006, p. 52).

A partir desse breve histórico econômico, vimos que Angra dos Reis, área de interesse da metrópole portuguesa e depois do Estado Nacional, possuía um evidente valor estratégico, tanto em relação ao mar, como na comunicação com o interior, pois durante séculos por ali passavam os metais

\footnotetext{
${ }^{51}$ Conforme Vasconcellos, "nos anos de 1827 até 1888, das 6.538 saídas, grande parte dos barcos que chegou ao Rio de Janeiro com carregamento de café, correspondendo a 5.320 $(69,6 \%)$ embarcações. A aguardente foi transportada por $772(10,1 \%)(\ldots)$. Dos portos do litoral, (...), destacaram-se os de Angra, local por onde passaram 3.229 embarcações, com uma média mensal de 13,1 barcos saídos daquele município (...)" (VASCONCELLOS, 2006, p. 47).
} 
das minas e, mais tarde, o café exportado e os escravos. Nesse sentido, os propósitos oficiais de controle eram claros, mas também inevitáveis os mecanismos das comunidades locais de subtrair-se a esse controle e, até mesmo, de utilizar-se das estruturas materiais de dominação para sua subversão, na forma de contrabando e de atos ilegais de todo tipo (FUNARI e OLIVEIRA, 2005 p. 35).

A vulnerabilidade dessa região, como dito, exigiu constantes esforços das autoridades da cidade do Rio de Janeiro. Entre as medidas tomadas pelo governo desta cidade para impedir a presença dos navios estrangeiros, encontra-se a construção de fortificações e pontos de vigias em vários pontos deste litoral (FUNARI e OLIVEIRA, 2005, p. 37). Como veremos adiante, há vários relatos sobre essa defesa, presentes nos documentos escritos e na produção historiográfica local. No entanto, foi por meio da pesquisa arqueológica que pudemos afirmar que esse sistema defensivo não foi formado apenas pelas estruturas defensivas citadas por BARRETO (1958, p. 216-218) e por estudos locais.

Pelo contrário, a região contou com um sistema simples de defesa, formado por baterias e pontos de observação espalhados pelas enseadas. Interessante é destacar que a instalação dessas estruturas tinha por base pontos favoráveis ao desembarque de invasores eventuais, como é o caso de Piraquara (conforme figura 5) uma enseada bem protegida e de água potável (FUNARI e OLIVEIRA, 2005, p. 38), que apresentaremos a seguir. 
Projeto Area Arqueológica de Piraquara - Angra dos Reis

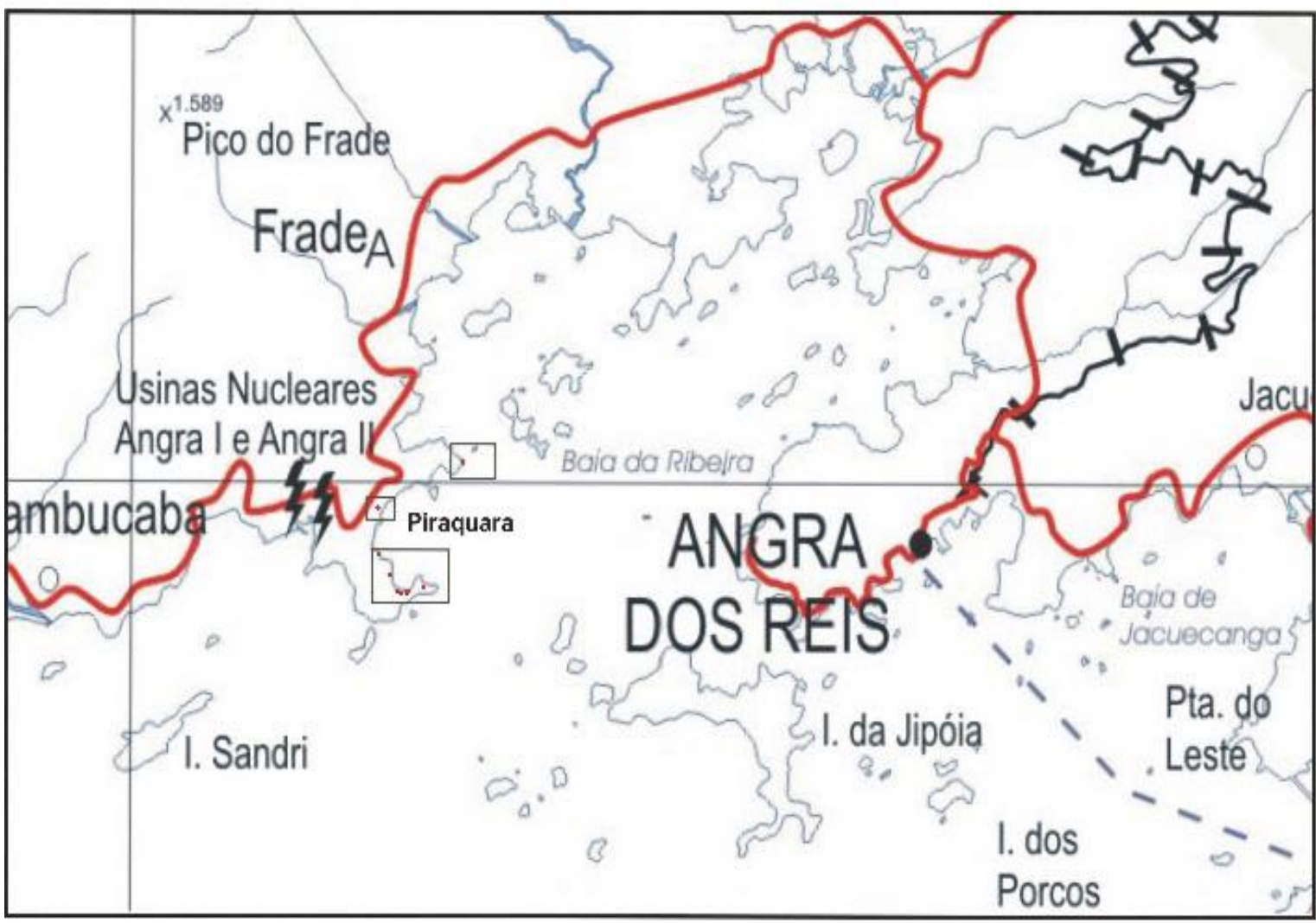

Figura 5 - Enseada de Piraquara 


\section{Projeto Área Arqueológica de Piraquara}

O Projeto Área Arqueológica de Piraquara tem suas etapas de campo, realizadas desde janeiro de 2004 até o momento, financiadas pela ELETRONUCLEAR, sob a responsabilidade da arqueóloga Nanci Vieira de Oliveira, do Laboratório de Antropologia da Universidade do Estado do Rio de Janeiro. Os resultados em Piraquara influenciaram diretamente a elaboração desta pesquisa e, por esse motivo, serão descritos a seguir ${ }^{52}$. Antes, porém, apresentamos alguns de seus desdobramentos.

Os estudos realizados na área de Piraquara de Fora culminaram na elaboração de um projeto de sítio-museu (figuras 6 e 7) e em ações de educação patrimonial (OLIVEIRA, FUNARI e MARIA, 2008, p. 6). De uma forma geral, as atividades desenvolvem-se em três eixos: sítio-museu e trilhas arqueológicas, centro de informação patrimonial e Jovens Talentos. Essas atividades estão sendo executadas em três etapas. De acordo com os autores,

"(...) La primera se llevó a cabo paralelamente con las intervenciones arqueológicas en Piraguara de Fora, con la realización de conferencias y cursos para los scout de Mambucaba y los profesores de la región. Durante esta etapa se elaboró un Banco de Datos de fuentes documentales y arqueológicas sobre la región. La segunda etapa consistió en la elaboración del proyecto para el museo de sitio y los caminos arqueológicos de Piraguara (...) En la tercera etapa, que se encuentra en desarrollo, la implementación de actividades de Educación Patrimonial comenzó por la asociación con el programa "Jovens Talentos" del Centro de Ciências", del estado de Rio de Janeiro, en unión con la Coordenadoria Regional de la Secretaria Estadual de Educação.

(OLIVEIRA, FUNARI e MARIA, 2008, p. 7)

Cabe ainda ressaltar que o programa "Jovens Talentos para a Ciência" conta com a participação de jovens indígenas Guarani, cujos membros possuem, até mesmo, auxílio financeiro. Estes alunos participam de cursos intensivos sobre noções de Arqueologia, Geologia, Etnologia e outras ciências, aulas práticas (escavação, laboratório, experimentação de tecnologia lítica,

\footnotetext{
${ }^{52}$ As imagens e os resultados aqui expostos foram gentilmente cedidos pela professora Nanci Vieira Oliveira e podem ser consultados no site http://www.cerescaico.ufrn.br/mneme.
} 

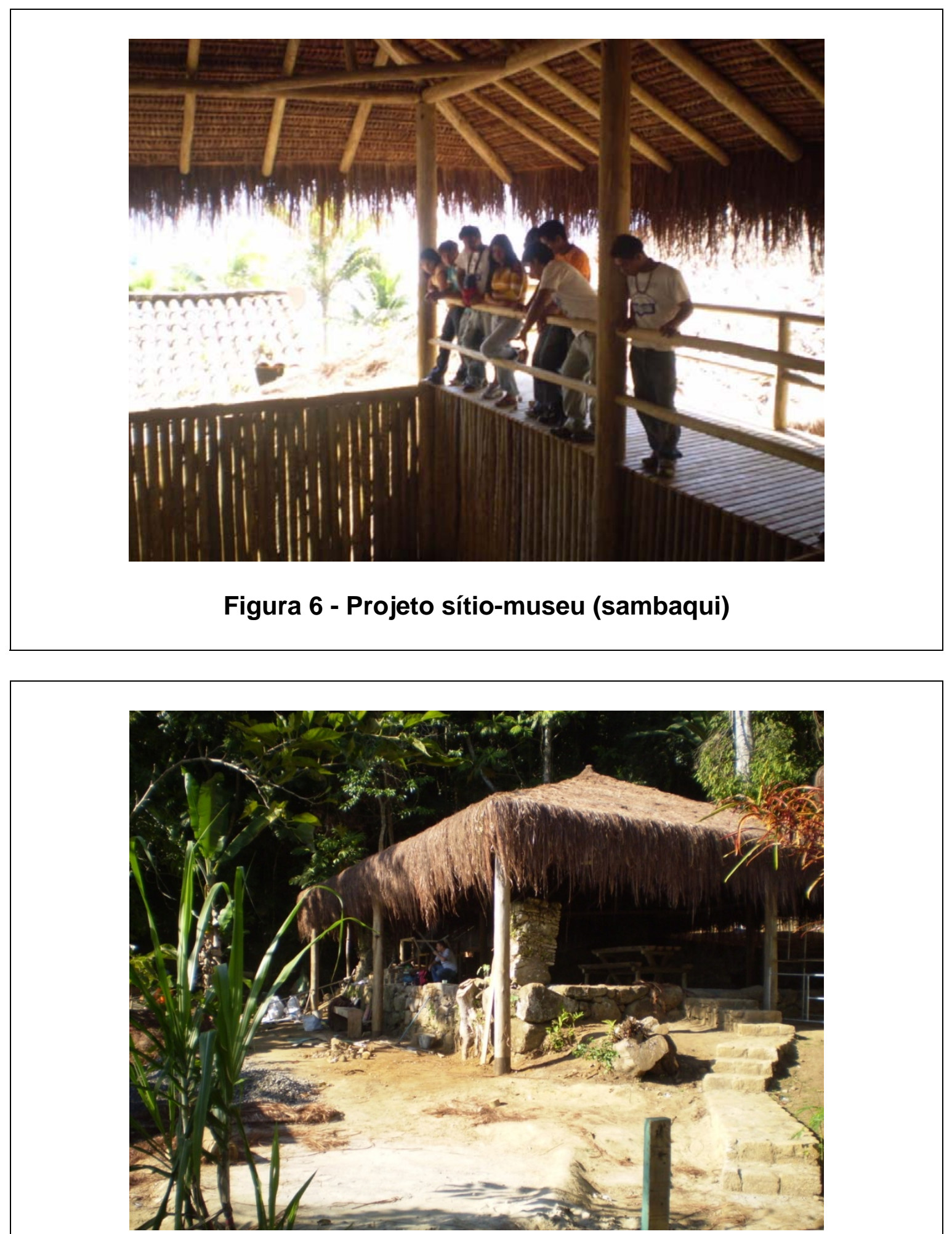

Figura 7 - Projeto sítio museu (estruturas de pedra) 
oficina de cerâmica etc.). A maior parte destas atividades é realizada com grupos indígenas e não indígenas, com o objetivo de promover a integração entre os participantes, sendo as ferramentas metodológicas bilíngües e pluriculturais (OLIVEIRA, FUNARI e MARIA, 2008, p. 12-13). É importante acrescentar que todas essas ações atuais tiveram a sua origem do projeto "Área Arqueológica de Piraquara", pesquisa ampla que identificou não somente ocupação indígena, mas também estruturas que indicam os aspectos defensivos da região, conforme veremos a partir de agora.

Nas etapas de campo que ocorreram em Piraquara ${ }^{53}$ foi constatada a existência de estruturas arqueológicas em pedras, sob a forma de muretas, alicerces e outras, já desfiguradas pelo tempo, ao nível do mar e em diferentes curvas de nível nos morros, em pontos com maior visibilidade do litoral (FUNARI e OLIVEIRA, 2005, p. 38).

Na praia do Velho, área de concentração da pesquisa em Piraquara bem próximas ao nível do mar, "(...) essas muretas ou alicerces encontram-se localizados em ambos os lados (...), permitindo uma boa visão da enseada e (...) a posição da artilharia impediria ou dificultaria o desembarque" (FUNARI e OLIVEIRA, 2005, p. 38-39). Assim, foi identificado ao lado direito dessa praia um muro de pedras que, mesmo impactado pela construção de uma Marina, permitiu a observação de sua extensão de 4,90 m, com $90 \mathrm{~cm}$ de largura e 1, $70 \mathrm{~m}$ de altura, orientado para nordeste (ver figura 8). No lado esquerdo dessa praia foi identificado (ver figura 9),

"(...) um muro de pedra, com setores retilíneo e côncavo, com diferentes alturas, em conformidade com o relevo do local. O muro apresenta uma extensão de aproximadamente $19 \mathrm{~m}$ e sua altura varia entre $1,30 \mathrm{~m}$ a $50 \mathrm{~cm}$, formando sobre este uma plataforma. A

\footnotetext{
${ }^{53}$ Nas palavras de Funari e Oliveira, "(...) o interesse pela ocupação colonial nas proximidades de Piraquara inicia-se na segunda metade do século XVIII, quando encontramos solicitação de carta de sesmaria na área do rio Mambucaba (...). De acordo com a carta de sesmaria do Padre Francisco da Nóbrega (...), este adquiriu terras em Piraquara para a construção de uma engenhoca (1797) (...). No levantamento documental do Arquivo Paroquial de Angra dos Reis surgiu também a indicação de uma fortificação em Piraquara em fins do século XVII (...). Informação também significativa obtida através das cartas de sesmarias, tanto na Piraquara (...) como ao lado desta, em Itaorna (1804), são indicações de pontas de arpoar e arpoador, termos indicativos de pesca de baleia na região (...)" (FUNARI e OLIVEIRA, 2005, 36).
} 


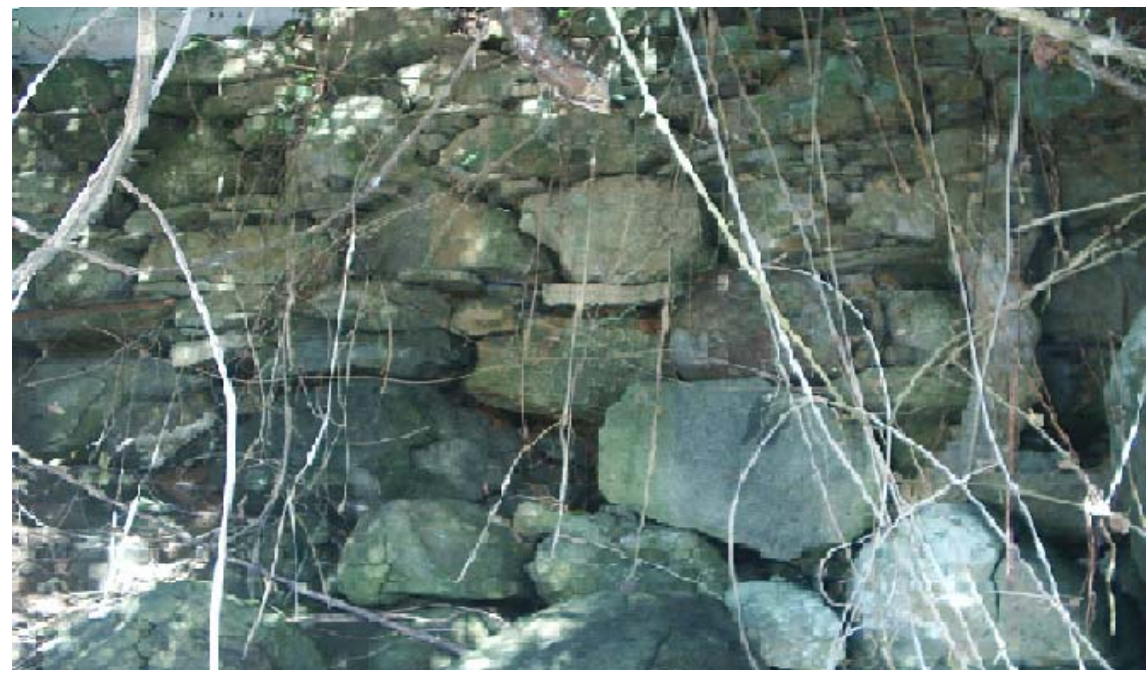

Figura 8 - Muro de pedra próximo à Marina

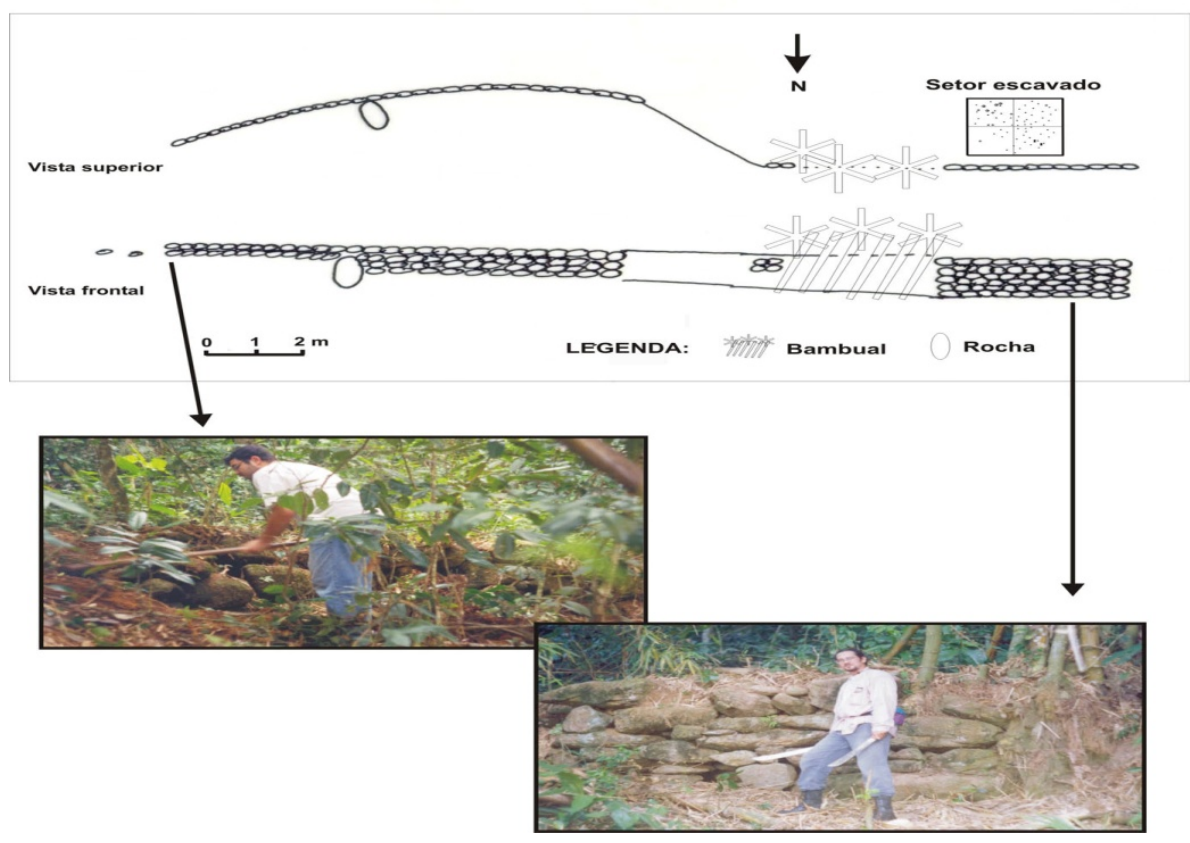

Figura 9 - Limpeza do muro de pedra 
orientação Norte é predominante (...). Deste ponto temse o controle de qualquer desembarque na praia (...)".

(FUNARI e OLIVEIRA, 2005, p. 39-41)

Ainda do lado esquerdo e no mesmo nível do muro descrito anteriormente, à distância de 150 m, foi identificada uma base, alinhamentos e um muro de arrimo, sendo todas essas estruturas em pedra (ver figura 10). Segundo Funari e Oliveira,

\begin{abstract}
"A limpeza da área e as prospecções permitiram identificar dois níveis de ocupação. Uma base de pedra com $12 \mathrm{~m}$ de comprimento e $5 \mathrm{~m}$ de largura, impactada pelo tempo e por ação antrópica; sobre esta, vestígios de uma construção que pela ausência de fragmentos de tijolos e telhas, teria sido uma casa de taipa coberta por palha, com parte de seu piso em cimento, delimitada por pequenos blocos de pedra alinhados (...). Para contenção, distante cerca de $2 \mathrm{~m}$ (...) junto ao mar, há um muro de arrimo".
\end{abstract}

(FUNARI e OLVIEIRA, 2005, p. 41)

Na Ponta da Fortaleza (aqui cabe destacar a toponímia do local), na outra extremidade de Piraquara, também à beira mar, foi encontrada uma plataforma de pedras de base retangular, tendo sua parede voltada para o mar, com 1, 55 m de altura e espessura que varia de 60 a $70 \mathrm{~cm}$. Próxima a esta estrutura foi constatada uma área de descarte alimentar, com grande quantidade de moluscos (ver figura 11). Cabe ainda destacar que,

"(...) deste ponto podem-se visualizar embarcações que passem entre Angra e a llha da Gipóia, enquanto que, na Ponta Grossa, a outra extremidade de Piraquara, visualiza-se a entrada por Paraty e as embarcações que contornassem a Ilha da Gipóia".

(FUNARI e OLIVEIRA, 2005, p. 43)

Sobre as estruturas em níveis mais elevados, foram encontrados alinhamentos de pedras, sempre próximos aos matacões ${ }^{54}$. Do lado direito da praia, a $10 \mathrm{~m}$ acima do nível do mar, foi identificada uma estrutura de alinhamento de pedras duplas em "L", com 9,6 m de comprimento, formando uma plataforma, orientada para Nordeste (ver figura 12). E, no lado esquerdo

\footnotetext{
${ }^{54}$ Grandes blocos de pedras.
} 

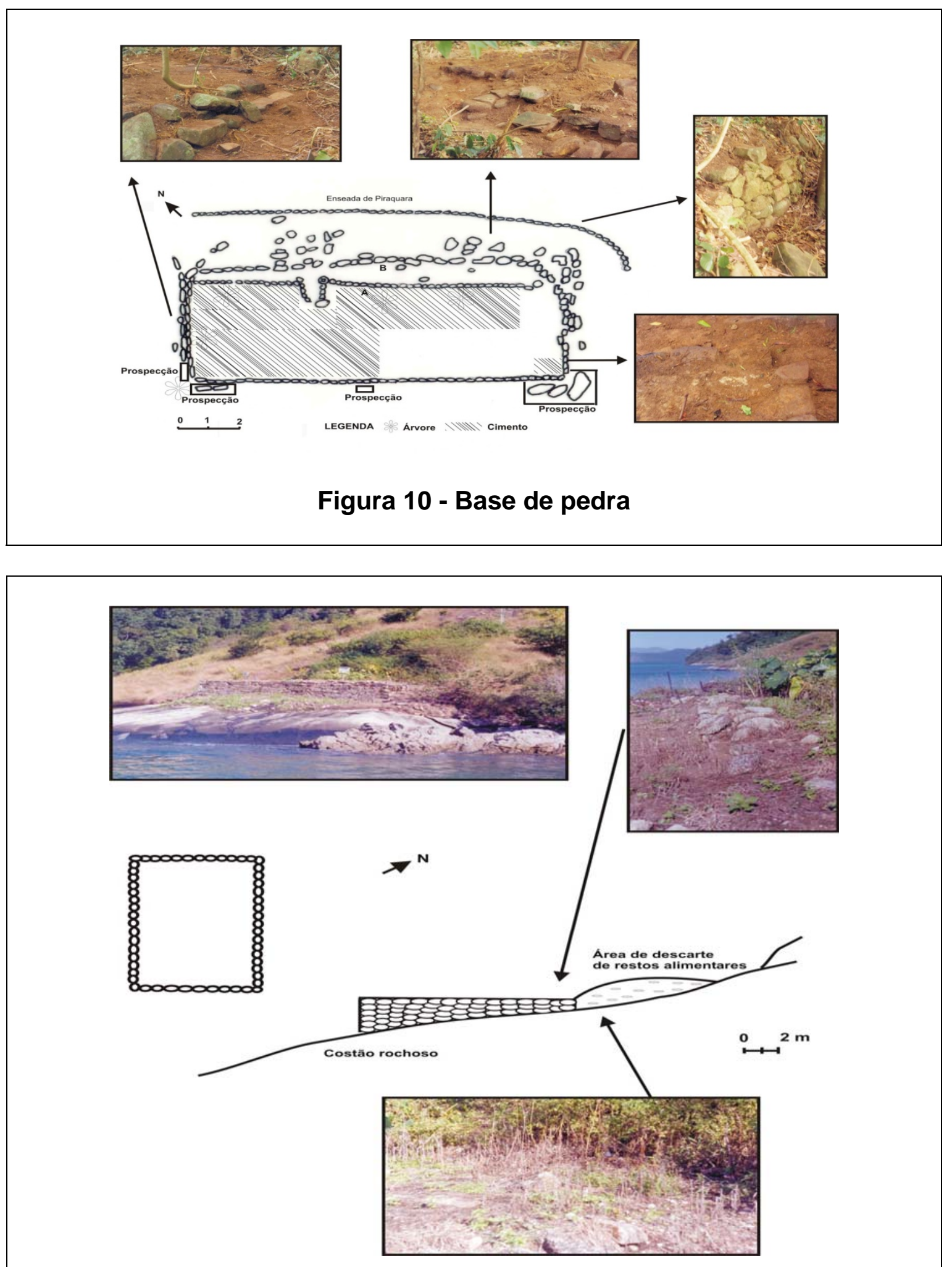

Figura 11 - Base de pedra retangular 
da praia, a $20 \mathrm{~m}$ acima do nível do mar, aparecem várias estruturas com pouca distância entre si (ver figura 13). De acordo com Funari e Oliveira,

"Na primeira delas podem-se observar duas estruturas de pedras, lado a lado, orientadas para o Norte. A menor destas, com 4,60 m de comprimento, muros de pedras superpostos totalizando $1,20 \mathrm{~m}$ de altura, encontra-se ao lado de um bloco de granito. A outra estrutura corresponde a uma base retangular com cerca de $7 \mathrm{~m}$ de comprimento e $6 \mathrm{~m}$ de largura. Esta apresenta um alinhamento simples de pedra, distante $1 \mathrm{~m}$ de um alinhamento duplo, com $50 \mathrm{~cm}$ de altura no seu lado frontal. No lado esquerdo, alguns blocos de pedra indicam ter existido uma contenção e, no lado direito ainda se observa parte de um alinhamento de pedras com $50 \mathrm{~cm}$ de altura".

(FUNARI e OLIVEIRA, 2005, p. 45)

Cabe aqui destacar que as prospecções nesta área evidenciaram um solo altamente rico em minério de ferro, apresentando um formato que lembra o encaixe de algum objeto/peça. Não muito distante destas estruturas, há um outro alinhamento simples de pedra, com aproximadamente 3 metros.

Mais um alinhamento de pedra encontra-se em um grande platô, como dito, próximo a um matacão. De forma diferente dos demais, "este alinhamento encontra-se orientado para o platô (...), sem uma visibilidade direta com o mar" (FUNARI e OLIVEIRA, 2005, p. 47). Esta estrutura tem cerca de $3 \mathrm{~m}$ de comprimento e sua orientação é para Sudeste (ver figura 14).

Em geral, os resultados das etapas de campo do Projeto Área Arqueológica de Piraquara apontam que as construções ao nível do mar parecem corresponder às baterias de terra e pedras, tendo sua ação reforçada por outras baterias, em nível imediatamente superior, pois todas permitem uma boa visualização da praia. As bases de pedras em níveis mais altos, que permitem uma linha de visada com um alcance muito maior, parecem indicar as vigias, ou seja, pontos de observação e sinalização da presença de invasores eventuais (FUANARI e OLIVEIRA, 2005, p. 50). É importante acrescentar que,

“(...) as estruturas descritas indicam que no local foram construídas as denominadas faxinas, representadas pelos alinhamentos simples de pedra, bateria de terra e vestígios de ocupação referentes aos vigias. Estas baterias de terra e vigias não garantiam a destruição do inimigo casual, tinham por objetivo dificultar 0 

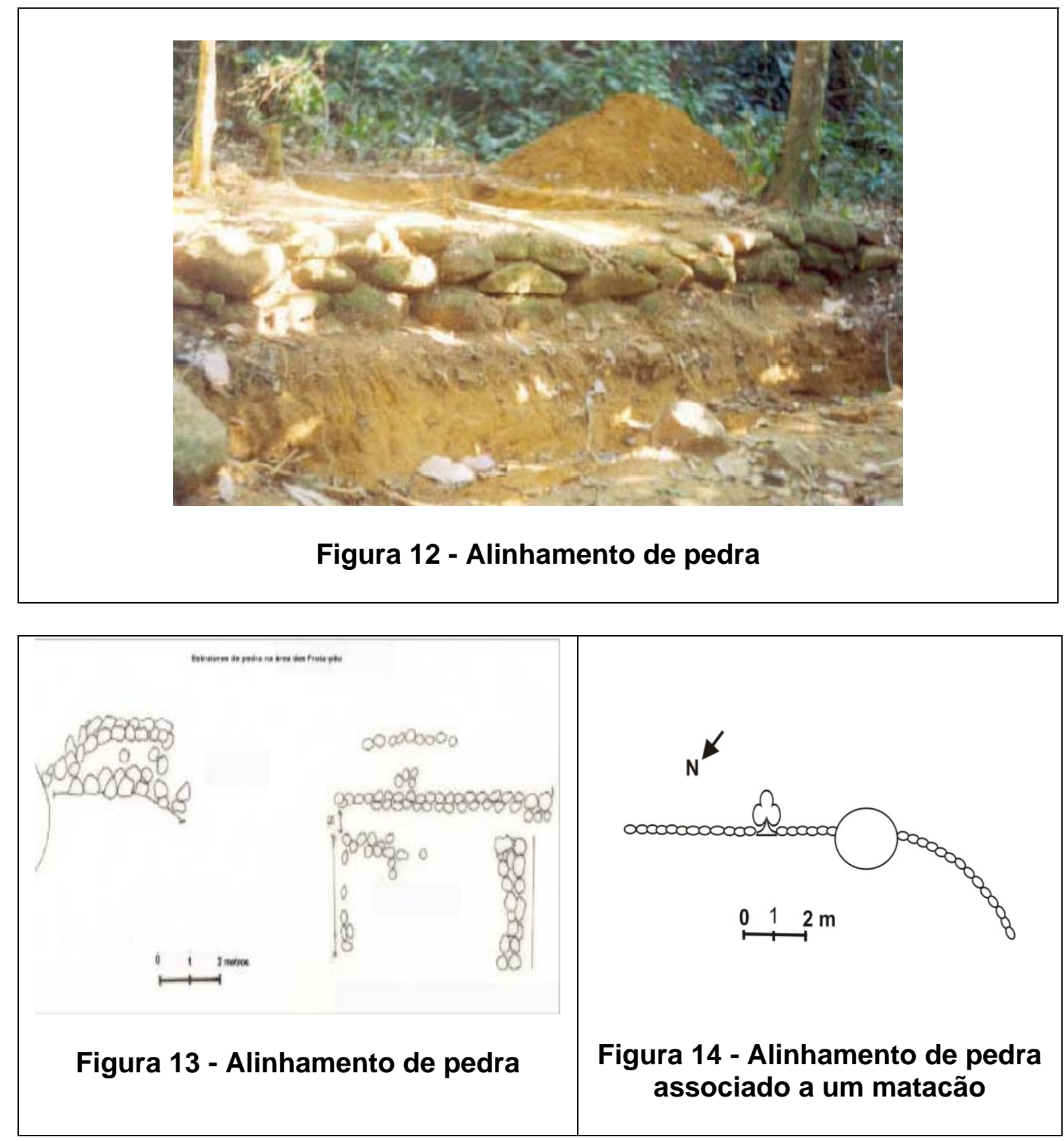
desembarque e causar "embaraços" que permitissem à Vila de Angra dos Reis o tempo necessário para a organização de sua defesa em caso de ataque estrangeiro".

(FUNARI e OLIVEIRA, 2005, p. 52)

A partir do Projeto Área Arqueológica de Piraquara, foi elaborado o Projeto "Contribuição para a Arqueologia Histórica em Angra dos Reis: as fortificações de Ponta Leste - um estudo de caso", já que Piraquara faz linha de visada com Ponta Leste (ver figura 15). Dessa forma, essas duas regiões poderiam estar ligadas a um sistema defensivo, formado por baterias e pontos de observação, dispostos pelos morros, assim como identificamos por meio da pesquisa arqueológica em Piraquara.

Entretanto, a única informação que tínhamos sobre Ponta Leste era a existência de uma fortificação, o Forte do Leme, em que o exército atribui o funcionamento nas primeiras décadas do século XIX. Embora essa informação seja incorreta, como já dito, o funcionamento do Forte do Leme foi relacionado aos Fortes do Carmo e de São Bento, ambas as construções defensivas localizadas na antiga vila de Angra dos Reis.

Nesse sentido, para tentar compreender o contexto defensivo em Ponta Leste era necessário compreender primeiro como foram as estratégias defensivas na própria vila de Angra dos Reis e quais eram as relações destas estratégias com a região de Piraquara. Para tanto, realizamos o levantamento documental e iconográfico ${ }^{55}$, bem como a leitura da produção historiográfica local, com os seguintes questionamentos: os fortes do Carmo e de São Bento realmente existiram em Angra dos Reis? Essas obras defensivas obedeceram aos mesmos padrões construtivos de Piraquara ou vice-versa? Qual a localização dessas estruturas? Havia mais fortificações em Angra dos Reis? Buscamos responder esses questionamentos a partir de agora.

\footnotetext{
${ }^{55}$ As instituições visitadas na cidade do Rio de Janeiro foram as seguintes: Arquivo Nacional, Arquivo do Estado do Rio de Janeiro, Arquivo Histórico do Exército, Biblioteca Nacional, Biblioteca da Marinha e Biblioteca da Universidade do Estado do Rio de Janeiro. Quanto às instituições de Angra dos Reis: Biblioteca Municipal, Colégio Naval, Convento do Carmo, Convento de São Bernardino de Sena, Igreja Matriz Nossa Senhora da Conceição, Tabelionato de Notas e $1^{\circ}$ Ofício de Registros e Tabelionato de Notas e $2^{\circ}$ Ofício de Registros de Imóveis, Títulos e Documentos. O levantamento documental e iconográfico ocorreu nos meses de janeiro e julho de 2006 e janeiro de 2007.
} 


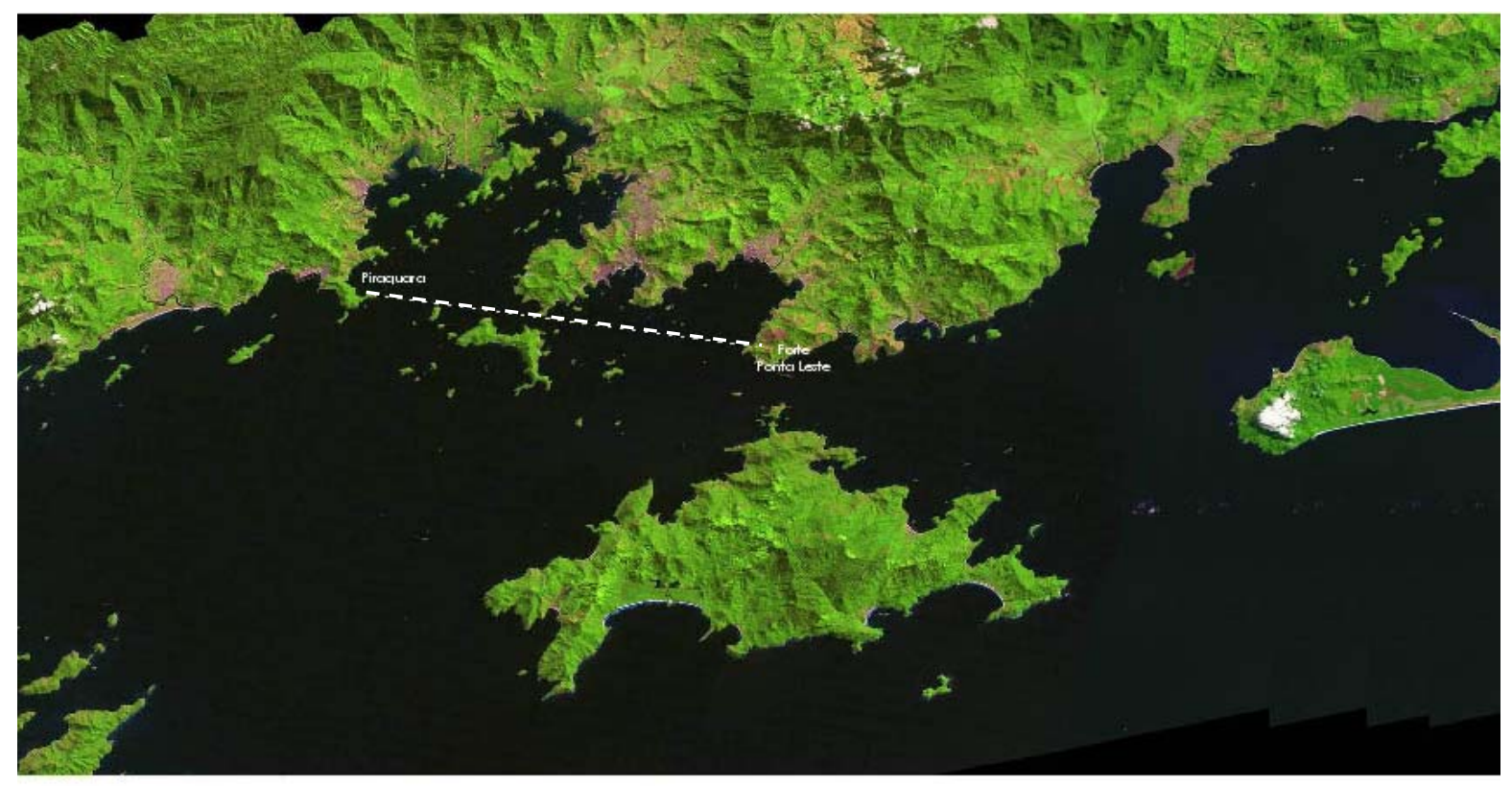

Figura 15 - Piraquara (esquerda) e Ponta Leste (direita) 
As estratégias defensivas de Angra dos Reis: discussões historiográficas e arqueológicas

Neste item iremos mergulhar na história de Angra dos Reis, discutindo um tempo referente à defesa de Angra dos Reis, pois a História é uma construção, um discurso com autoria (FUNARI e CARVALHO, 2005, p. 17). Dessa maneira, há muitas histórias, ou seja, há uma grande variedade de visões sobre o mesmo assunto. No entanto, na medida em que discursarmos, as fontes escritas, levantadas durante as pesquisas sobre o litoral fluminense, aparecerão. Podemos assim mostrar o que foi produzido sobre a defesa de Angra dos Reis, tanto na versão da historiografia, como na versão dos documentos escritos. Além disso, serão utilizados aqui os mapas históricos, plantas e os canhões ainda presentes na cidade de Angra dos Reis.

De um modo geral, a documentação histórica utilizada neste item é constituída por cartas, ofícios, regimentos, relatórios, entre outros. Em outras palavras, documentos de cunho oficial, amplamente utilizados pela historiografia, na análise de fatos, na busca de erros, acertos e planos táticos militares (CONCEIÇÃO, 2005, p. 5).

Muitos destes documentos circularam entre os responsáveis pelo funcionamento da colônia. Assim, esse circuito comunicativo produziu uma massa documental. E, por meio dos documentos tratados aqui, podemos extrair informações sobre a relação que se estabeleceu entre a metrópole e sua colônia, especialmente no que diz respeito às obras defensivas e à materialidade das mesmas na região de Angra.

Antes de tudo, é importante ressaltar que tentaremos compreender a defesa da Vila de Angra e procuraremos relacioná-la com Piraquara e Ponta Leste, pois acreditamos que essa região formava um sistema defensivo, composto por baterias e pontos de observação. Aqui, neste item, procuramos informações que nos permitam fazer essa relação.

A historiografia local (REIS, 1988; CAPAZ, 1996; LIMA, 1974; MELLO, 1987; MENDES, 1970, 1980, 1988) parece apontar para um senso comum: Angra dos Reis defendeu-se do contrabando e do perigo de invasão 
estrangeira através de duas fortificações, uma construída no outeiro do Carmo e outra no de São Bento, ambas no século XVII. Neste mesmo século, o governo português teria mandado construir mais duas fortificações: uma na llha do Barros e outra no local denominado Ponta da Cidade, sendo que chegaram a ser iniciadas, porém não foram concluídas.

Entretanto, ao mesmo tempo em que a produção historiográfica local, em um primeiro momento, parece compor um consenso, percebemos que esta apresenta informações conflitantes, como veremos a seguir.

LIMA (1974, p. 83) afirma que a partir de 1640, quando Portugal fica livre do domínio da Espanha, a baía de Angra dos Reis foi sucessivamente assaltada por piratas. Nesse sentido, por meio de tantas reclamações feitas pelos habitantes da nova vila, o Governo da Metrópole mandou construir, nos extremos opostos da mesma, os Fortes do Carmo e o de São Bento. Segundo este autor, nos tempos coloniais estes fortes estavam armados com canhões de calibre 12, 18 e 24, assentados em canhoneiras de pedra e cal, construídas sobre a direção do engenheiro Brigadeiro Pedro Álvares de Andrade.

Aqui cabe fazer uma ressalva: a idéia exposta por LIMA parece indicar que o brigadeiro Pedro Álvares de Andrade foi responsável pela construção desses fortes, em 1640. No entanto, o mesmo só esteve em Angra dos Reis em fins do século XVIII (CAPAZ, 1996, p. 145), quando pertencia ao quartel militar do campo de Santana, localizado na Ilha Grande, conforme documento que mostraremos adiante.

Em contrapartida, MENDES (1970, p. 387) afirma que por ordem de Dom João IV, atendendo ao pedido que the foi sugerido em 1646, pelo coronel de Engenheiros, Álvares Cabral, determinou que se construíssem os dois fortes. A fortaleza do Carmo, mandada construir neste mesmo ano, foi inaugurada em 1650 e era artilhada com duas baterias, a do Cavaleiro e a do Lume d'água, com canhões de calibre 18 e 24, sendo que esteve operante até 1873, quando era guarnecida por um furriel e quatro soldados, sob o comando de um oficial. E, a fortaleza de São Bento, construída no morro de São Bento, também teria sido inaugurada em 1650 e possuía apenas seis canhões de calibre 12, mas, por ter sido erguida muito próxima ao mar e sem nenhuma conservação, logo se arruinou. 
Sobre a materialidade da Fortaleza do Carmo, também chamada de Forte de Nossa Senhora do Carmo, Forte de São José de Nossa Senhora do Carmo ou apenas Forte do Carmo, MENDES (1970, p. 388) diz que era um vetusto prédio, construído com argamassa de cal e azeite de peixe, dividido em duas seções, sendo uma o quartel propriamente dito e a outra, a casa de pólvora. Dentre os seus compartimentos havia o xadrez, a sala de armas, o alojamento dos Oficiais e dos Praças, refeitório, cozinha, vários salões e pequenas alcovas, sendo que, por ocasião das várias epidemias que assolaram Angra dos Reis, a mesma era usada como isolamento dos enfermos. Suas portas e janelas teriam sido confeccionadas de pau-brasil retirado do próprio Morro do Carmo.

Este autor aponta que dessa tradicional obra de defesa de Angra dos Reis nenhum vestígio resta, a não ser apenas o seu imponente portão de ferro, que hoje se encontra na entrada do cemitério da Igreja de Nossa Senhora da Conceição, ou seja, da Igreja Matriz da cidade.

A afirmação de REIS (1988, p. 19), não difere muito do que foi anteriormente citado: pelos longos anos de hostilização feita por piratas, o Governo da Metrópole teria mandando construir duas fortificações na Vila da Ilha Grande, nos outeiros de São Bento e do Carmo, sendo que, do último, no morro que passou a denominar-se morro da Fortaleza, restam ainda vestígios. Ao contrário, LIMA (1974, p. 84) afirma que dos dois fortes, principalmente, o de São Bento apresenta vestígios.

Entretanto, de acordo com um dos documentos que conseguimos apurar, em fins do século XVII, mais precisamente em 1699, podemos propor que a vila de Angra dos Reis ainda não havia sido fortificada, visto que os seus moradores concordaram em se reunir para mostrar aos franceses que havia gente na vila que thes pudessem resistir, como pode exemplificar o documento abaixo,

"Em os quinze dias do mes de Março de 1699 anos nesta Vila de Angra (...) se ajuntarão os vereadores e officiaes da Câmara para fazerem vereança, e nela acordárão por um Quartel pera dia de São Jozé dezanove de março se juntarem os moradores na Vila para contar aos francezes que há gente na terra que lhes possa resistir (...) (grifo meu)".

(Apud Revista do IHGB, Vol 271 - abril, junho, 1966. Capítulo IV - Vários documentos de Angra dos Reis da llha 
Grande e outros lugares da Capitania do Rio de Janeiro, p.

O próprio MENDES (1970, p. 391) aponta que em princípios do século XVIII, continuavam as incursões de navios estrangeiros pelas praias angrenses, o que obrigou o governador da Vila de Santos solicitar ao governo português que mandasse fortificar mais eficazmente a barra da Ilha Grande, o que foi concedido por Carta Régia de 1704. No entanto, afirmar que a vila deveria ser fortificada mais eficazmente nos transmite a idéia que a vila já poderia ser fortificada, o que não parece sugerir os documentos a seguir, sobre o mandar-se o Capitão de Engenheiros à Ilha Grande ver se podia fazer alguma fortificação para a defesa e autorização para executar as obras,

"Senhor: Com os navios corsários que andam nesta costa e o roubo que fizeram na sumaca ${ }^{56}$ dos açúcares da Ilha Grande, mandei o capitão de Engenheiros ver se podia fazer alguma fortificação para que defendesse as embarcações daquele porto e impedisse o desembarque nele e me informa que seria muito conveniente o fazer-se para este ministério, porque estão expostos a tudo quanto quiserem fazer deles qualquer embarcação que ali chegue; com esta notícia os Vereadores e remeteram a carta que faço presente a V. M., com a planta que fez o Engenheiro, para que sendo $\mathrm{V}$. M. servido ordenar que se faça, e se executar, enquanto não tenho a resolução de Vossa Majestade, determino, se aqueles moradores quiserem concorrer e mandar o engenheiro fazê-la de faxina ${ }^{57}$ e por-lhe 4 peças que é o bastante para este intento, que para maior força não há capacidade. Deus guarde a Real pessoa de Vossa Majestade. Muitos anos como seus vassalos havemos mister (grifo meu)". 08/02/1704. Governador do Rio de Janeiro - Dom Álvaro da Silveira.

(Apud MENDES, 1970, p. 391)

Em resposta a esta carta temos o seguinte documento,

"Dom Álvaro da Silveira e Albuquerque: Eu, a Rainha da Grã-Bretanha, Infanta de Portugal vos envio muito saudar. Havendo visto a conta que deste com a planta que remetestes da fortificação que intentais fazer na Ilha

\footnotetext{
${ }^{56}$ Sumaca pode ser definido como barco pequeno, de uma vela.

57 Faxina pode ser descrito como ramos de árvores ou estacaria, dispostas ao longo da fortificação para proteger a artilharia. No tratado de Antônio Rodrigues, lente da "Escola Particular dos Moços Fidalgos do Paço da Ribeira", de 1576, este termo já é utilizado, no Capítulo 6, sobre Fortificação de Terra. Nele, o autor versa sobre "fachyna" - "(...) não é outra couza senão ramos de arvore delgados de tres palmos ate quatro muyto dereyto, asy como são os vymes" (RODRIGUES \{1576\} Apud BUENO, 2001, p. 319).
} 
Grande, para a defesa dos piratas que costumam andar por aquele porto fazendo as pilhagens que me dais notícia. Me pareceu dizer-vos, que no que toca fazer-se a defensa da Vila de Angra dos Reis que fica em terra firme de fronte da llha, é muito acertado por ser uma vila a borda d'água, com porto capaz de qualquer embarcação ${ }^{58}$, porque ainda que a vila seja pequena, será muito conveniente que esses poucos moradores não estejam expostos a mercê de qualquer corsário. $E$ pelo que toca ao sítio assinalado na planta com a letra $P$, se deve fazer quando o sítio não der lugar a outra obra mais valente o que da planta não consta, por não trazer petipé, e assim vos ordeno mandeis executar o dito reduto, e quando se lhe possa acomodar alguma defensa lateral será melhor, para que tomareis o parecer do Sargento-Mor Engenheiro José Paes Esteves. Escrito em Lisboa (...) (grifo meu)". 18/09/1704, Rainha Grã-Bretanha, Infanta de Portugal.

(Apud MENDES, 1970, p. 392)

MENDES afirma que essas obras foram feitas em 1706. No entanto, depois dessa data somente em 1727 se fariam novos reparos, “(...) conforme constata a Carta-Régia de 9 de julho daquele ano, que manda aumentar as fortificações e construir um cais defronte das fortalezas do Outeiro do Carmo e da Ponta de São Bento" (1970, p. 394), documento não encontrado.

Para CAPAZ (1996, p. 145) essa iniciativa não foi tomada. Este autor diz que, quando da tentativa de Duclerc, em 1710, Angra dos Reis era uma cidade "aberta", ou seja, a vila não tinha fortes que a protegessem. De acordo com este autor, em 1712, dediciu-se fortificar a vila, no entanto, essas medidas teriam sido tomadas apenas em 1726, sob o governo de Luís Vahia Monteiro.

É interessante aqui abrir um parêntese e falar sobre a invasão de Duclerc em Angra dos Reis, assunto que a historiografia local também apresenta informações conflitantes. Sobre essa invasão, MELLO (1987, p. 56) afirma que a notícia de um próximo assalto ao Rio de Janeiro começou a ser veiculada desde 1704. No entanto, com o passar do tempo, vendo que nada acontecia, as autoridades começaram a relaxar com as medidas de segurança e os moradores da costa continuaram com seus tratos e comércio com os estrangeiros, muito embora as autoridades do reino insistissem com as autoridades locais no sentido de que toda a cautela fosse tomada. Segundo este autor, várias foram as recomendações de Arthur de Sá Menezes,

${ }^{58} \mathrm{O}$ porto de Angra dos Reis é mais profundo que o de Paraty, por exemplo, que só dava entrada a pequenas embarcações, como veremos em nota adiante. 
governador do Rio de Janeiro, no sentido de que o povo se abstivesse de ter contato com os estrangeiros. Proibiu-se ainda que as pessoas que viessem das minas permanecessem na costa durante a estadia de navios estrangeiros.

Em 1710, quando na barra do Rio de Janeiro surgiu a esquadra de Duclerc, esta foi rechaçada pelo fogo das fortalezas que a protegiam, a esquadria entrou na Baía da llha Grande, onde ancorou. Duclerc mandou dois navios a Angra dos Reis, onde houve troca de tiros com poucos danos físicos e materiais.

Já MENDES (1980, p. 64) diz que de 27 de agosto a 8 de setembro de 1710, Angra dos Reis foi violentamente e incessantemente bombardeada, tendo como principais alvos o Convento do Carmo e o primeiro convento dos franciscanos, que veremos adiante. Sendo que o primeiro ficou bastante danificado, apesar da resistência oferecida pela Fortaleza do Carmo que, segundo o autor, já funcionava desde o século XVII. Nas palavras de Mendes,

Valentemente repelidos pela tropa do Governador, (...), resolveram os invasores bombardear intensamente a vila o que fizeram durante todo o dia 07 de setembro de 1710, alvejando, deliberadamente o Convento do Carmo e o dos franciscanos - o primeiro o da CACHOEIRA, que era o que existia na época (...)".

(MENDES, 1988, p. 35)

Entretanto, de acordo com a documentação que será apresentada adiante, podemos propor, assim como CAPAZ (1996, p. 145), que somente com o governo de Luís Vahia Monteiro ${ }^{59}$ (1725-1732) é que começam a ser tomadas medidas concretas para a defesa do litoral sul fluminense, em especial na cidade de Angra dos Reis. É com este governador também que, conforme já explicado em nota anterior, Paraty e llha Grande voltam a pertencer à jurisdição do Rio de Janeiro, pois este alegava não poder acabar com a pirataria e o contrabando do ouro na região, devido à distância e a dificuldade de comunicação existente entre a Capital e àquelas vilas, sendo

\footnotetext{
59 Sobre este governador, nas palavras de Mello, "somente na governança de Luís Vahia Monteiro, o famoso Onça, como o povo Ihe apelidara pelo seu comportamento sisudo e austero, conseguiu-se reduzir o contrabando e a pirataria na llha Grande. O incansável trabalho de Vahia Monteiro nesse sentido fez com que o mesmo se conflitasse com as autoridades subalternas e com os clérigos, ação essa que o levou finalmente à loucura. A ele se deveu o encerramento definitivo do escoamento de ouro por Paraty, a utilização do Caminho Novo, onde mais difícil era o desvio dos quintos" (MELLO, 1987, p. 61).
} 
que por esse motivo, Vahia Monteiro propõe à Corte portuguesa que fosse definida a jurisdição das vilas, como nos mostra o documento abaixo,

"Entre a llha grande, e terra firme esta hum dilatado Porto onde os navios estrangeiros dam fundo, e fazem escala quazi sempre com fim denegócio, ainda que não seja mais que dando fazenda a troco dos refrescos que pedem, defronte desta llha estão duas villas a saber ade Angra dos Reis dajusdição desta Capitania, eade Peraty do governo de São Paulo, que dista daquella Cidade quinze dias dejornada, edesta quatro, advertindo que a Ilha Grande he desabitada, eos moradores davilla de Angra dos Reis são todos pobres, esem pocebilidades para fazerem negociação nesta villa por ser desta jurisdição, asiste hua comp. de Infantaria aq. Só pode remediar os fraudes que nella se intentarem fazer, porem denem hú modo impedir os de Peraty que donde sempre se fizerão por q. aly há cazas ricas (...) os quais nem oGovernador, e Capitão gn. De São Paullo pode evitar pela distançia emq se acha, ficando por este modo exposto este Governo ao injusto labeo de se fazerem negociasões pella llha Grande, que seconcedera toda por ser fora daminha jurisdição (...) semefaz percizo reprezentar a V. Mag. Que convem muito a seu Real Serviço, q. estas duas villas com a Ilha Grande fiquem sogeitas ao governo de São Paullo, ouadesta, para q. hú só governador responda pellos fraudes, que aly se fazem (...) (grifo meu)". Rio de Janeiro, 2 de junho de 1725.

(Archivo Nacional, Governadores do Rio de Janeiro, Correspondência activa e passiva com a Côrte, 17251730 , p. 15)

A partir do momento em que Paraty e Ilha Grande voltam a pertencer à jurisdição do Rio de Janeiro, em 1726, Luís Vahia Monteiro, conforme nos relata o documento que se segue, visita o litoral fluminense e manda fortificar a região, inclusive a cidade de Angra dos Reis.

"(...) depois dapartida dafrota fui logo vezitar estacosta ate avilla de Peraty para aparte donorte para della hú inteiro e devido conhecimento, por ser amais trigada, e freqüentada denavios estrangr. principalmente naria dallhagrande, que he aultima desta jurisdição, aqual he porto do mar, eseacha amargem delle cituada napraya ordeney hú caes flanqueado, quepode servir de defença nocazo q. os estrangeiros, ou inimigos queirão fazer algú dezembarque nadita vila, o que só podem conseguir com lanchas por ser aquella enseada tão esprayada que navazante damaré ficão estas embarcações tadas em seco, eos navios dão fundo tão afastado, que não podem com artilharia ofender avilla, 
cujos os moradores se offerecerão afazerem asua custa ocaes conforme atestada de cada hú, cuja obra entendo aprefeicoarão brevem.te pello gosto comq. se abraçarão, (...) evoltando avilla de Angra dos Reis, frontr. dallha Grande, e dos portos mais freqüentados dos estrangr. , naqual por estacauza asiste dePrez. por ordem de V. Mag. Huá companhiadeinfaria, evendo que esta, e villa estavaõ indefezas, equeacadapaço, podiaõ ser insultadas pellos estrang. como tem socedido discorry algum modo deosforteficar, eachando hú Monte chamado Santo Antonio, cuja pontatoca aomar etam vezinha davilla queacobretoda, (...), ordeney q. sefizeçe neste monte paraficar servindo deCidadela, (...) elogo dispus aforma de forteficar o dito monteque tem decrivo para todas as partes, elhe desenhey hú foço emtodo asircumvalação, enaponta domar huabateria, q. Ihehadefazer deterra, efachina, para nella por alguas peças demenos calibre, deque aqui há sobra, com oq. Entendo ficaraõ aquelles moradores totalmenteseguros da hostilidade, quealy podem intentar os inimigos (...) etodaamais obrasefaz acusta dos moradores, sendo aCamara, etodos osmais priçipaes os primeyros q. se offerecerão afazer o foco, o qual Ihedeixey logo repartido dando a hum a tareya, quepedio conforma a poce década hú, e negros, qq. tinhao enaverdade meedificou osello, q. estes moradores mostrarão aoserviço de V. M. pellogosto, eamor comq. se aplicao aesta obra, que espero esteja daqui ahú anno em termos delhe por artilharia, o queexecutarey, semesperar novaordem asimpella necessidade como por achar huá de 19 de novembro de 1712 emque V. M. manda forteficar aquelavilla pondolhe aartilharia, noque até agorasenão cuidou (grifo meu). CARTA do Governador Luiz Vahia Monteiro, "Se fortificarce a Villa de Angra dos Reis da Ilha Grande e a Vila de Peraty". Rio de Janeiro, 7 de novembro de 1726.

(Archivo Nacional, Governadores do Rio de Janeiro, Correspondência activa e passiva com a Côrte, 17251730, p. 158-159)

Sobre a obra de defesa na cidade de Angra dos Reis, mandada construir no Morro de Santo Antônio, a historiografia local também não apresenta consenso. CAPAZ (1996, p. 146) afirma que o Morro de Santo Antônio passou a se chamar Morro da Fortaleza, sendo que essa construção, para o autor, refere-se à Fortaleza do Carmo. No entanto, REIS (1988, p. 19) afirma que o morro onde foi construída a referida fortificação era o Morro do Carmo que, posteriormente à sua construção, passou a denominar-se Morro da Fortaleza. Assim, seguindo a idéia deste último, a Fortaleza do Carmo teria sido 
construída no morro do Carmo, próxima ao Convento que tem o mesmo nome e com a Fortaleza de São Bento teria ocorrido o mesmo. Mas então, onde seria o morro de Santo Antônio?

Aqui é necessário abrir outro parêntese: a cidade de Angra dos Reis contou com a presença de três ordens religiosas: carmelitas, beneditinos e franciscanos (figura 16). Os carmelitas foram os primeiros a chegar e tiveram a construção do Convento do Carmo iniciada na passagem do século XVI para o $X V I I^{60}$, sendo inclusive, anterior à edificação da vila no local atual (REIS, 1988, p. 29).

Em seguida vieram os beneditinos, que, de acordo com os documentos da época, em 1598 receberam por doação do capitão Jorge Correia, por Carta de Sesmaria, um terreno na cidade para a construção de seu Convento ${ }^{61}$. Ainda segundo os documentos, os frades tomaram posse deste terreno em 1616, tendo sua casa monacal inaugurada no dia de São Gonçalo, no ano de 1626 (MENDES, 1970, p. 283).

Por fim, vieram os franciscanos, que se estabeleceram na cidade em 1652, num local denominado Cachoeira (figura 17), sendo que o Convento de São Bernardino de Sena, desta Ordem, teria sido fundado no ano seguinte neste mesmo local. No entanto, os franciscanos tiveram uma segunda casa monacal em Angra dos Reis, em outra localização que, assim como a primeira, tinha como orago São Bernardino. Esta foi inaugurada em $1763^{62}$ e funcionou até 1859.

É interessante aqui destacar que o povo angrense, segundo MENDES (1988, p. 32), apelidou os conventos dos franciscanos como Conventos de Santo Antônio, em virtude destes frades também serem conhecidos como religiosos antoninos ou de Santo Antônio. Nas palavras do autor, “(...) pelo

\footnotetext{
${ }^{60}$ A data de construção do Convento do Carmo não é precisa. A historiografia local aponta os anos da possível construção: 1593, 1601 ou 1602 (REIS, 1988, p. 29). Conforme Mendes, "construída perto da praia, num outeiro que ficou logo conhecido como Carmo, florescia mais uma casa carmelita (...). Tão grande era o seu progresso que em 1617 foi totalmente concluída a construção e, conseqüentemente, erigida em Convento (...)" (MENDES, 1980, p. 32).

${ }^{61}$ Segundo Mendes, "funcionava o Convento de São Bento, como era comumente chamado, a oeste da Vila, num outeiro, defronte da praia que tomaria seu nome (...)" (MENDES, 1970, p. 283).

${ }^{62}$ Nas palavras de MENDES, "(...) em junho de 1763, por impropriedade do local onde fora construído, na antiga paragem conhecida por Cachoeira (...) por ser o terreno muito pantanoso e eivado de sapos, cobras e outros animais (...) mudou-se a comunidade para o seu novo claustro. O atual (...) Convento de São Bernardino de Sena" (MENDES, 1988, p. 36).
} 
Figura 16 - Mapa de Angra dos Reis em 1894

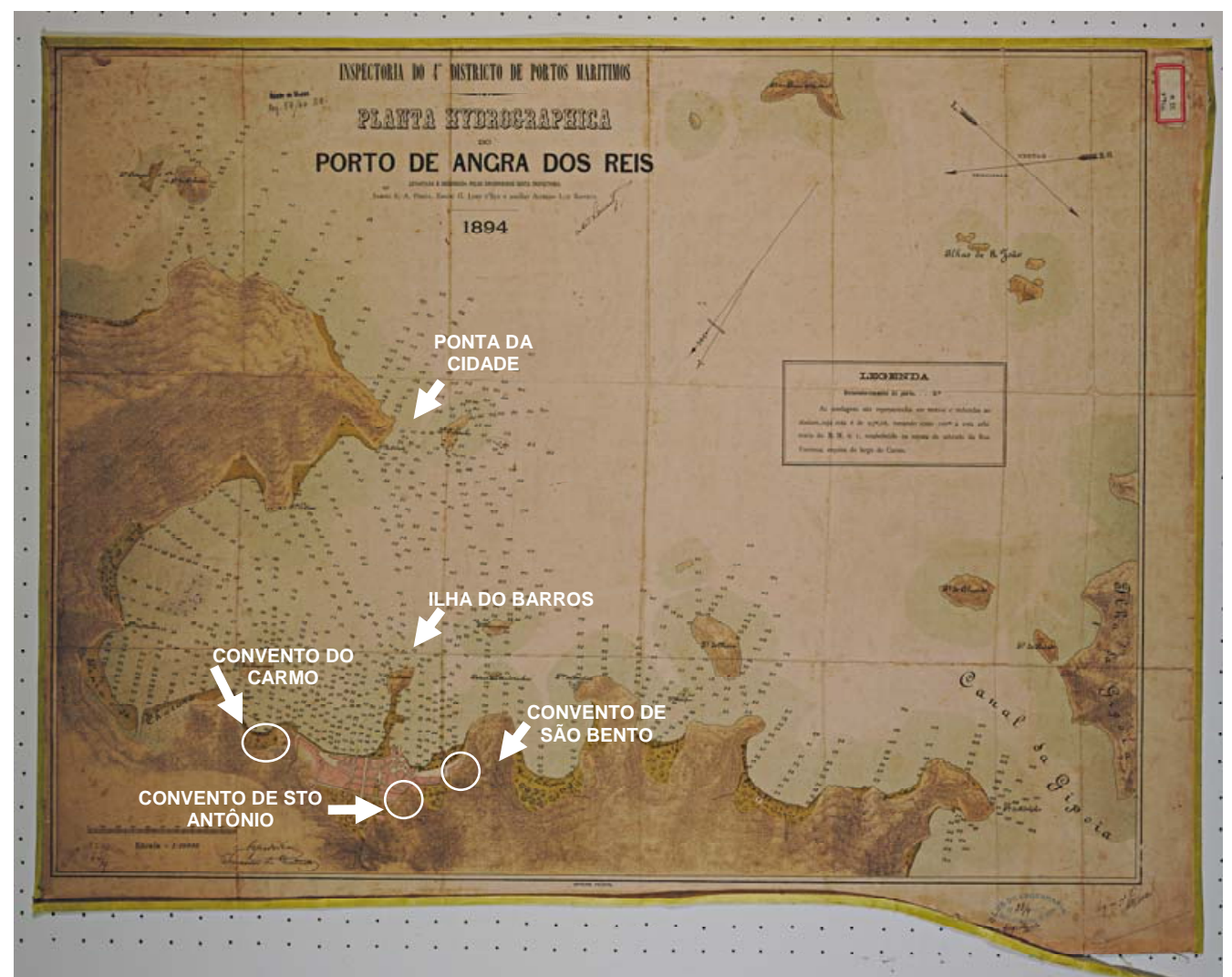




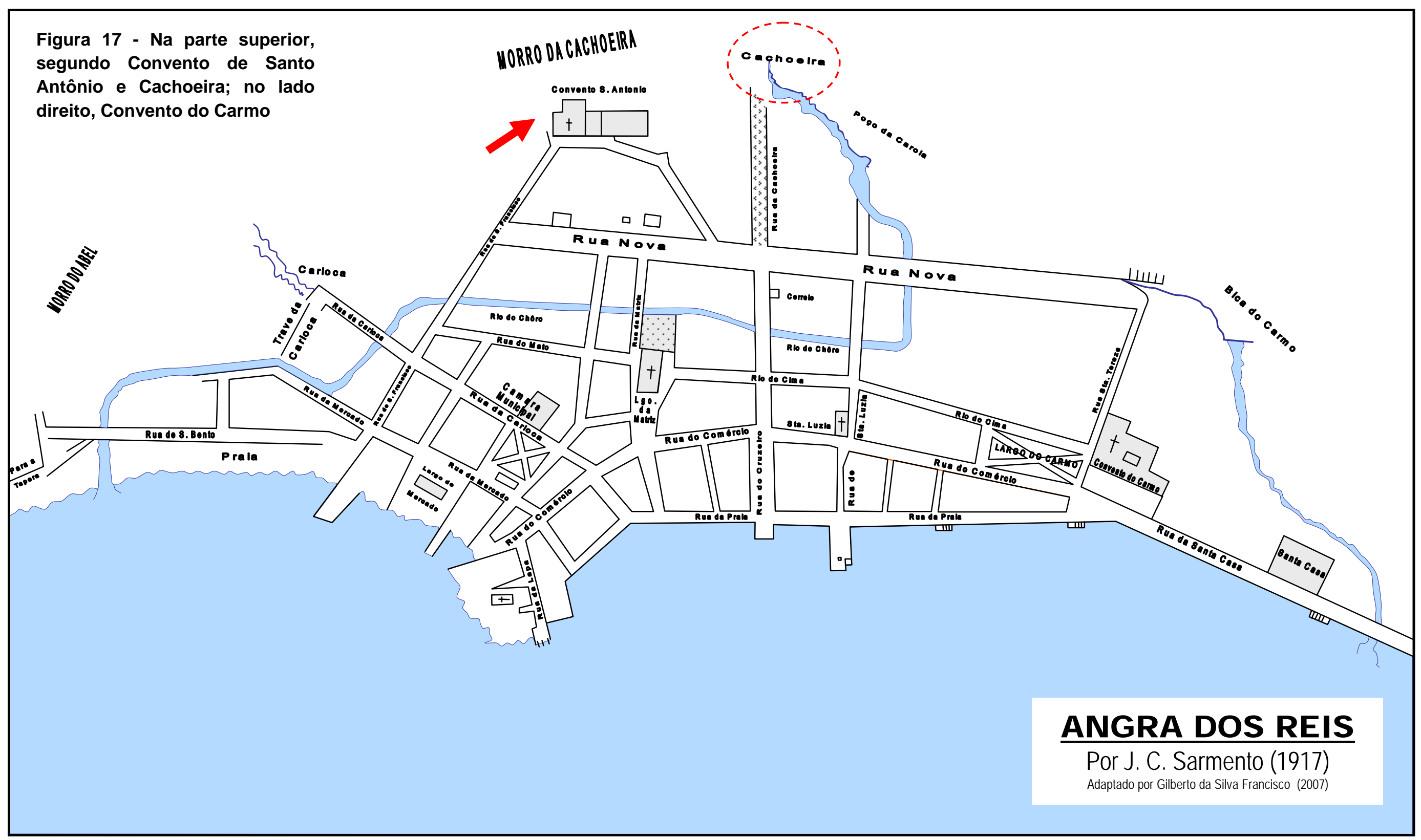


mesmo motivo, acreditamos, o morro das vizinhanças dos Conventos, igualmente, ganhou a denominação que até hoje se conserva - Morro de Santo Antônio (grifo meu)" (MENDES, 1988, p. 32).

Dessa forma, o Morro de Santo Antônio era próximo ao local onde foram construídas as duas casas monacais dos franciscanos. Atualmente, na cidade se conhece um Morro de Santo Antônio, totalmente ocupado, sendo que este se encontra ao lado das ruínas do segundo convento de São Bernardino de Sena (ver figura 17). No entanto, se houve uma terceira fortificação neste morro, não encontramos sua referência em nenhum outro documento.

O que podemos apresentar são dois ofícios de Luís Vahia Monteiro, de 1732, citados por MENDES (1988, p. 36). O primeiro seria endereçado ao alferes João da Costa e o segundo ao frei Manoel de São Roque, estes seriam o comandante da Fortaleza do Carmo e o guardião do primeiro Convento de São Bernardino de Sena, respectivamente. Na possibilidade deste autor estar certo, apesar dos documentos não citarem nem o nome da Fortaleza e nem o nome do Convento a que estavam endereçados, podem indicar que a primeira casa monacal dos franciscanos era muito próxima à Fortaleza do Carmo, o que poderia confirmar a hipótese de CAPAZ (1996) de que a Fortaleza do Carmo teria sido construída no Morro de Santo Antônio. Conforme mostramos abaixo,

"Sobre a morte da vaca tem vossa mercê feito alguns depósitos porque suposta a levaria matar, segundo a ordem que deixei para não andarem na fortaleza, não a deveria deixar comer aos Soldados ao que se cometeu roubo, antes, deveria mandar dar parte ao Convento, para que aproveitasse se quisesse; à vista de que mandará logo satisfazer o seu valor, ou comprar outra para entregar ao Convento e o Alcaide mandará soltar em vista desta, sem embargo de ser preso se acaso fazia a diligência na fortaleza sem lhe dar parte, a advertindo que passagem da vila para outra banda, pela bateria da artilharia, não se pode impedir de dia, nem de noite, enquanto não estiver toda a obra acabada", 02/05/1732.

(Apud MENDES, 1988, p. 36)

"Sinto que o primeiro raio caísse na rês desse Convento, ainda que foi bem morta pelos despresos com que se olha para as coisas de El-Rei e minhas ordens, pois, foram bem publicas para que o gado não fosse as obras daquela fortaleza, mandando avisar para que os donos 
pusessem pastor; mas foi muito mal comida pelos Soldados e por esta causa ordenou ao Alferes que logo a mande pagar ao Convento ou entregar outra vaca melhor, e sobre este ponto da comida da vaca teria com as Varas outro procedimento se não me atalhasse 0 acelerado muito de Justiça, que Vossa Paternidade usou e as arrogância dos religiosos que foram à Fortaleza de que estou informado pelo Alferes mais todas pessoas que vem dessa vila, que ouviram as vozes, e isto é o que me tem mais admirado, achando-se Vossa Paternidade por Guardião desse Convento, de cujas virtudes, esperava eu, outros efeitos, mais estes os atribuiu as arrogâncias que produziram em muitos religiosos as discórdias que tiveram entre si (...)". 20/05/1732.

(Apud MENDES, 1988, p. 37)

Entretanto, na etapa de levantamento documental identificamos uma planta e um mapa que nos indicam que, diferente do que CAPAZ (1996, p. 146) afirma quando se refere que o Forte do Carmo foi construído no Morro de Santo Antônio, essa fortificação foi construída no Morro do Carmo, próxima ao Convento do Carmo, hoje conhecido como Morro da Fortaleza.

A primeira planta não possui data e nem nome de quem a elaborou. No entanto, diz claramente que é da fortificação construída no Morro do Carmo na Vila de Angra dos Reis da Ilha Grande. Nela há a indicação do Convento do Carmo, uma via de acesso, duas construções não identificadas e a Fortificação, formada por uma Casa de Pólvora, um Quartel e duas Baterias. Percebe-se pelo desenho que eram construções simples de defesa, ou seja, dois muros, sendo um voltado para o Canal (ver figura 18) que liga à llha do Barros ao continente (bateria 3) e a outro voltado para a praia do Carmo (bateria 4). Na legenda dessa planta, descrita na figura, há a informação que a praia do Carmo era constantemente visitada por navios estrangeiros e que essa segunda bateria estaria sendo construída para reforçar os tiros sobre essa praia.

O mapa é mais preciso, pois mostra a data de 1839, ou seja, a obra de fortificação já estava pronta e formada pelas duas baterias (figura 19). No entanto, por mais que ambos os desenhos não estejam com escala e tenham tamanhos bem diferentes, é possível identificar que a primeira bateria (bateria 3), citada na planta anterior, está com sua face voltada para o lado oposto, e 
Figura 18 - Planta Forte do Carmo

\section{Fortificaçam do Monte do Carmo na Villa de Angra dos Reis da Ilha Grande}
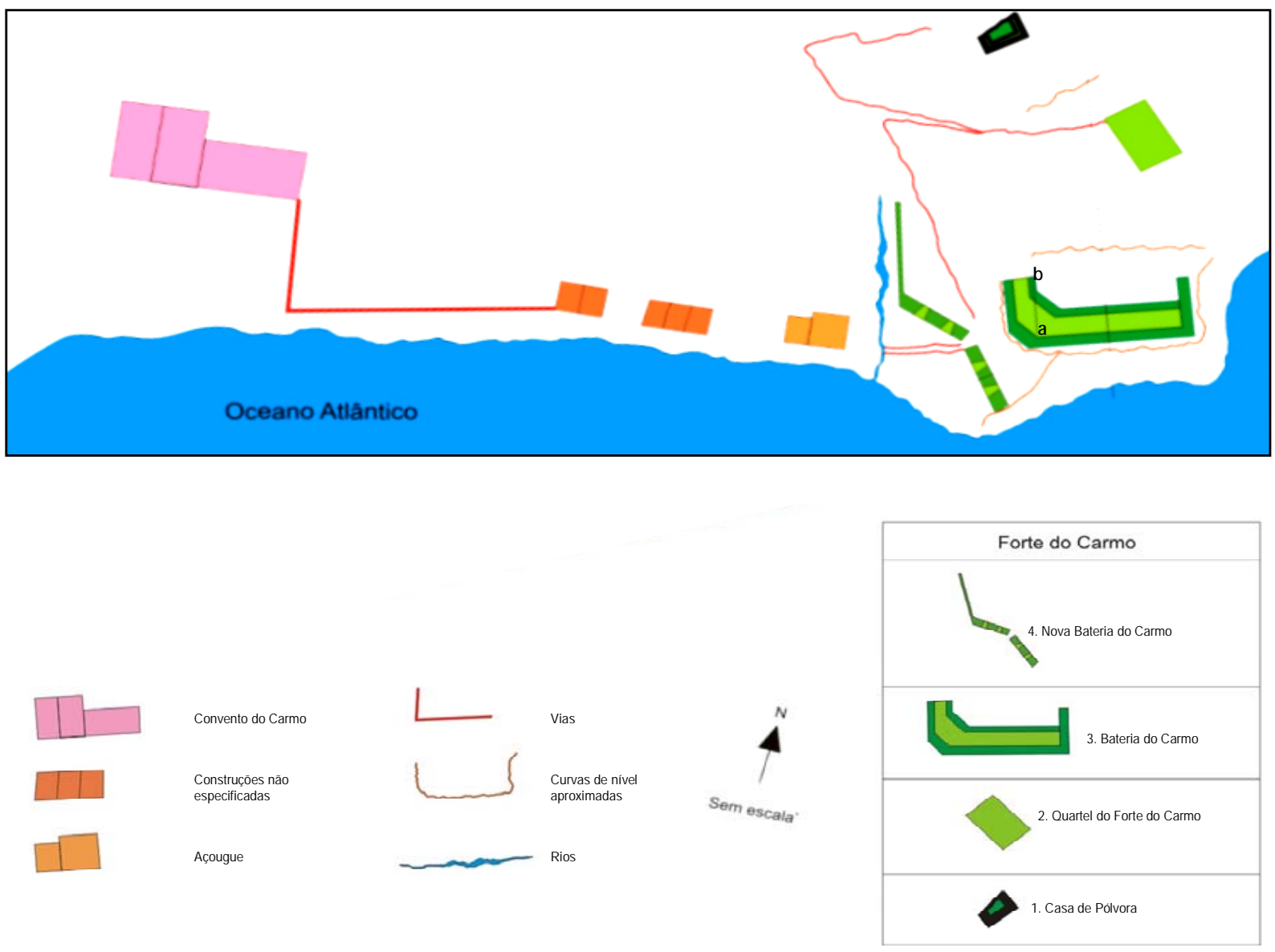

Na planta há a seguinte legenda:

"1 - Casa de Pólvora, 2 - Quartel do Forte do Carmo, 3 - Bateria do Carmo que tinha antigamente a $3^{a}$ face voltada na direção ab e que fiz a mudança que se vê na planta para poder ter fogos diretos sobre o canal que passa entre o Forte e a llha do Barro que não haviam antigamente, 4 - Nova bateria que construí, primeiro para ter fogos sobre a praia que é de desembarque, e que não era defendida, segundo para aumentar os fogos sobre o canal; terceiro para sustentar a bateria superior visto que por esta inferior é o único lugar acessível para aquela". 
Figura 19 - Forte do Carmo em 1839

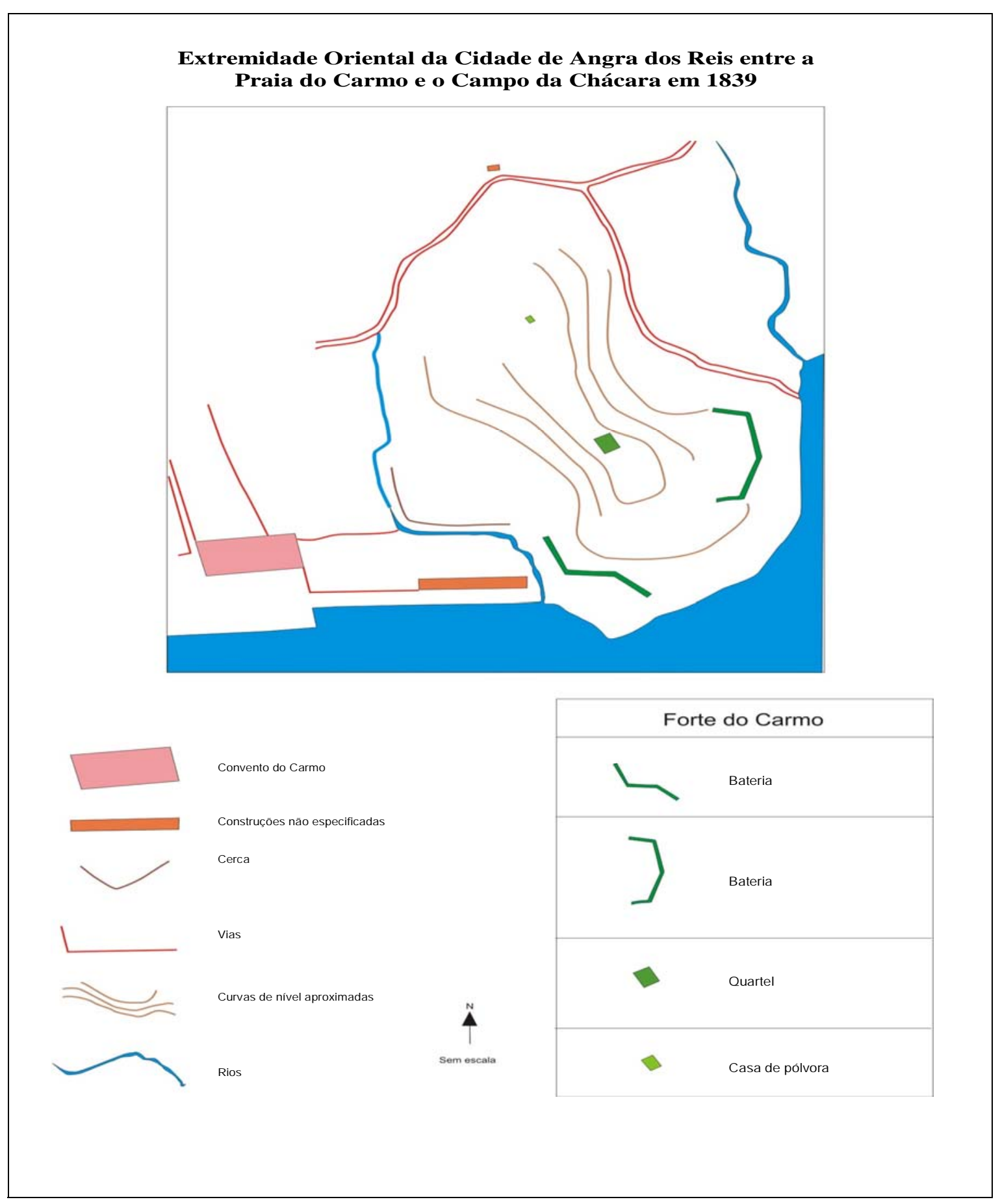


não para o Canal da llha do Barros, conforme consta na legenda do primeiro desenho.

Importa aqui é destacar que essas plantas indicam que o Forte do Carmo foi uma obra simples de defesa e, como já dito, era formado por duas baterias, informação essa que a historiografia local também apresenta. A diferença de Piraquara, por exemplo, é que as estruturas defensivas estão dispostas de modo isolado, mas em Angra dos Reis, a existência de duas ou mais baterias num mesmo local é que define essa construção como Forte. De uma forma geral, o Forte do Carmo obedeceu ao mesmo padrão, formado por baterias, que identificamos em Piraquara.

Outro fato que devemos nos atentar, também presente nos documentos e na historiografia local, é sobre o comércio realizado entre os moradores e os navios estrangeiros, citado inicialmente. MENDES (1970, p. 393), afirma que, ainda no século XVIII, os piratas e corsários estrangeiros teimavam na sua faina criminosa de molestar os laboriosos e tranqüilos habitantes da Vila de Nossa Senhora da Conceição da llha Grande. Entretanto, como já dito, esses mesmos habitantes não parecem ter sido tão calmos e laboriosos assim. A documentação aponta que havia a venda irregular de mantimentos, o que talvez permitisse o sustento de muitas famílias angrenses. Já no século XVII, autoridades do Rio de Janeiro chamavam atenção sobre este fato,

"(...) porque alguns moradores daquelas ilhas têm trato e correspondência com os inimigos, por serem alguns deles homisiados das Capitanias e Ihes dão mantimentos e ajuda de carga de pau (brasil), se me deve dar ordens para me obedecerem e eu os poder castigar e mudar das ditas ilhas, e presos o mandar a esse reino". Carta de Martim de Sá a Felipe II, sobre as preferências dos estrangeiros, para se refrescarem, pelas ilhas de São Sebastião, Grande, dos Porcos, Sant' anna e Santa Catarina". (grifo meu) 20/04/1617.

(Apud MELLO, 1987, p. 15)

"Vossas Mercês se têm havido muito maus
servidores de Sua Majestade, (...), merecendo mandá-
los castigar; pois não substaram ao Capitão-Mor
quando lhes foi avisado de que estavam navios
estrangeiros na costa, e que indo a este porto dois que
não encontraram neste, Ihes fizeram agasalho, e lhes 
dessem mantimentos que tivessem a troco de ouro e prata, ou gêneros, contanto que não fossem fazendas, que haviam de pagar direitos a Sua Majestade, e indo lá depois mais os navios me não fizeram aviso algum da sua chegada, nem da saída, e agora fazem o mesmo da sua arribada que consta-me terem lá chegado, me não têm feito aviso. $E$ Vossas Mercês não me emendarem em semelhantes ocasiões obrigar-me-ão a que os castigue; na forma referida lhes podem assistir com todo o necessário tendo sem embargo disso as cautelas que já Ihes adverti, e se devem ter havido navios estrangeiros no porto (...) (grifo meu)". Carta sobre a estadia de De Gênes em Angra dos Reis, Sebastião de Castro e Caldas repreende os membros da Câmara. 21/03/1696.

(Apud MELLO, 1987, p. 65)

Para tentar solucionar este problema, Luís Vahia Monteiro publicou, em 1725, antes mesmo de visitar a região, um Regimento no qual informava que era proibido o comércio com os navios estrangeiros na costa brasileira. Interessante aqui é destacar que este governador mais uma vez avisava a Corte portuguesa da falta de fortificações na cidade de Angra dos Reis, como veremos a seguir,

"(...) e porque nada do referido se pode executar na Villa de Angra dos Reis assim por não haver fortaleza debaixo de cuja artilharia fasa vexame, nem pessoa conjurisdição para o fazer, nem fazenda real para lhe assitir, de nenhum modo se lhe deve permitir prática aos ditos navios, que para qualquer cousa forem a Ilha Grande, porque não ignorando elles o referido sempre devemos crer que com algum industrioso pretexto querem por aquela parte entroduzir fazendas, extraindo ouro, cujo comércio lhe he proibido com rigorazas pennas aos vassalos (...) que cultivaram semelhante tracto, porque a experiência tem mostrado que os ditos estrangeiros tem metido muita fazenda pelo porto da Ilha Grande daqui em diante, se observará com eles o seguinte. Tanto com algum navio estrangeiro entrar no dito porto, com o capitam do presídio mandará a seu bordo examinar a causa com que entra nelle, e se declarar algua necessidade, Ihe mandará dizer que ahi não pode socorrer pela sobre ditas razões, e que pode hir ao Porto de Santos, ou desta cidade onde será socorrido (...) porém no caso de não usar deste remédio (...) se quizer dilatar no dito porto, (...) e mandará logo fazer um protesto judicialmente pelo escrivão da Câmara, para que dentro em vinte, e quatro óras saya do dito porto, aliás que será tratado como inimigo, e tido por pirata, quebrantador da paz, e quietação pública. E se com 
effeito despois do protesto, não quizer sahir para fora, porão as ordenanças em armas de sorte, que guarnecidas as prayas, se lhe impida todo o comércio. (...) Dando-me ao mesmo tempo parte da sua arribada, e da continuancia de se querer sustentar no porto, (...) que o mandareis buscar, para o confiscar, farão avizo ao coronel de Paraty para que se previna da mesma forma: Porém seantes do protesto declarar que tem necessidade de ágoa, ou de lenha, (...) se lhe deixará a dita agoada, e lenha com tais cautelas e guardas, e brevidade, que não possa aver a menos suspeita de comércio algum. Advirto (...) ao cappitam do prizídio as cautellas e vigilância com que se devem haver nas pessoas, que mandar a bordo fazer as perguntas, e protesto para que essas não farão algum comércio (...) de toda a falta que ouver na execução desta ordem responderá o cappitam presídio e os oficiaes da ordenança cada hum pela parte quel lhe tocar (...) (grifo meu)". 08/11/1725.

(Revista do IHGB, Vol 271 - abril, junho, 1966. Capítulo IV - Vários documentos de Angra dos Reis da llha Grande e outros lugares da Capitania do Rio de Janeiro, p. 363-365)

Ainda sobre as fortificações, depois do governo de Luís Vahia Monteiro, a notícia que temos são dois relatórios: um de 1793 e outro de 1797. O primeiro, um relato de inspeção do Sargento-mor Joaquim Correa da Serra, a mando do governo colonial, sobre as obras de defesa de Angra dos Reis e Paraty, conforme apresentamos abaixo,

"Desta diligência seguiu-se alargar-se mais o terreno da praça, que há no Forte de Nossa Senhora do Carmo sito na Terra Firme ao nascente da Vila de Angra dos Reis, e fazer-se um entrincheiramento abarbela. Também se delineou um ângulo reentrante da parte esquerda daquela fortificação, por se julgar a propósito para defender 0 saco, que naquela parte permite desembarque. A sobredita fortificação do morro do Carmo é composta de três lados desiguais: o primeiro está guarnecido de uma peça que faz fogo para a parte da Vila: o segundo tem cinco peças que jogam para o mar, e o terceiro tem uma peça que defende a praia correspondente. Reedificou-se o Quartel que serve de alojamento a uma Companhia de Infantaria, e construí-se de novo uma Casa de Pólvora com todas as mais circunstâncias respectivas a mesma fortificação. Na ponta do Morro de São Bento se projetou um Reduto, que se acha completo com a sua artilharia; dentro do qual se fizeram Quartéis de Pedra e Cal para acomodação de 40 até 50 pessoas com casa para pólvora e mais petrechos. Parecendo-me bem imaginada Fortificação da Ilha do Barro, por cruzarem 
os seus tiros com os da Ponta do Carmo e do São Bento, ordenei que se fizesse os desmonte da referida Ilha que ficava servindo de padastro às fortificações da Vila, cuja obra se acha com grande adiantamento, como também a comunicação que se pretende fazer de Terra Firme para a mesma llha do Barro. Não seria desacertado a ponta da Vila, por defender a sua entrada com a Ilha do Barro; mas por falta de artilharia, que a guarnecesse, não se tem tratado dessa obra. Também se projetou, e concluiu um entrincheiramento na praia que fica junto a Praça de Nossa Senhora do Carmo, com seu flanco, tendo extensão mais de quarenta braças. $O$ objetivo principal de todas estas fortificações é defender os desembarques, que pretende $o$ inimigo fazer na Vila. $O$ que de nenhum modo se pode embaraçar na llha Grande, tendo estas duas barras limpas, uma de quatro léguas de largo, e outra de uma légua, e seis, ou sete enseadas grandes seguras, e com fundo capaz de ancorarem embarcações em considerável distância da terra e ao abrigo dos ventos. Quanto à Vila de Paraty, defensável pela natureza (pois quase o tiro de peça há um baixio, que nas mais altas marés não chega a ter oito palmos de água) só se tratou de consertar um Quartel para a tropa, e de formar um entrincheiramento de faxinas sobre os alicerces já feitos de mais tempo para um cais, fazendo-se também um depósito de faxinas, para entrincheirar toda a marinha, quando seja preciso (grifo meu)."

(Biblioteca Nacional - Seção Manuscritos - Notícias de Ilha Grande e Paraty - II, 31, 21,4)

O segundo, um documento de 1797, do brigadeiro Pedro Álvares de Andrade, então comandante militar na região da baía de Ilha Grande, citado no início deste item, que dava conta às autoridades do Rio de Janeiro da situação dos fortes da cidade de Angra dos Reis,

"O Forte de São José de Nossa Senhora do Carmo, está guarnecido com 7 canhões, três de calibre 12, e quatro de 6, está completo e o seu quartel consertado, junto a ele em plano superior se acha construído em pequeno Trem onde se acha a pólvora e palamentas das fortificações. A praia da praça de Nossa Senhora do Carmo está fortificada com uma trincheira e seu flanco e sua extensão excede a quarenta braças. A tapagem das bocas das ruas que dão serventia para a marinha e dois pequenos redutos que de necessidade se devem fazer, por falta de faxinas, não estão feitos. A Ilha do Barro está desmoronada incompletamente e não está fortificada por não ter tropa e artilharia para a guarnecer, este porto importante deve ser fortificado ou arrasado 
pela curta distância em que se acha na frente da vila que é de tiro de mosquete; a comunicação desta ilha para o continente está principiada. A fortificação do pontal de São Bento está inteiramente completa e guarnecida com 6 canhões, dois de calibre 9 e quatro de 6. O quartel para a guarnição deste forte está quase completo e creio que por todo o mês de abril próximo ficará pronto. O que falta para inteiramente se cumprirem as respeitáveis ordens de Vossa Excelência é o fazer a pequena llha da Francisca que comanda o Forte de São Bento e se acha na distancia do alcance do fuzil e o ilhote do Carmo que se acha ainda em menor distância diante do forte da mesma denominação (grifo meu)". Carta Enviada ao Vice-Rey por Pedro Álvares de Andrade, 16/03/1797.

(Revista do Ateneu Angrense, ano III, no $4-12 / 1975$,

A partir da comparação destes dois relatórios, podemos propor que 0 entrincheiramento $^{63}$, de 40 braças, na praia da Fortaleza do Carmo foi concluído, assim como as obras de conserto do quartel da dita fortificação. Também que, nos anos entre a confecção dos dois relatórios, o Forte do Carmo não recebeu nenhuma peça e se manteve armado com o total de sete canhões. Sobre o Forte de São Bento, conforme o segundo relatório, o seu quartel ainda não estava completo, mas já estava armado com seis canhões.

Quanto à Ilha do Barros, o primeiro relatório aponta ser bem imaginada uma fortificação neste local. Entretanto, o segundo afirma que a Ilha não havia sido fortificada e o seu desmonte já havia sido iniciado em 1793 e embora bastante adiantado ainda não estava completo. REIS (1988, p. 21) diz que a Ilha do Barros oferecia a curiosidade de ser ligada à terra firme por um banco de areia, por onde, na maré baixa, se passava a pé enxuto. Esse banco de areia, para o autor, foi construído para dar passagem até o forte existente na Ilha. No entanto, como dito, o segundo relatório aponta que não foi construída nenhuma obra defensiva neste local. Faz-se necessário indicar que este local foi demolido para a construção do porto de Angra dos Reis (LIMA, 1974, p. 84), o que impossibilita a execução de pesquisas arqueológicas.

O primeiro documento ainda afirma não ser desacertado fortificar a Ponta da Vila, sendo que essa localização pode ser também conhecida como

${ }^{63}$ Entrincheiramento é considerado uma obra de defesa não permanente, ou seja, é uma obra de fortificação destinada a satisfazer as necessidades táticas de um determinado momento (BARRETO, 1958, p. 24). 
Ponta da Cidade. Entretanto, o segundo relatório, como mencionado, sugere que novas fortificações não haviam sido construídas até aquele momento, incluindo a llha do Barros e a Ponta da Cidade, onde a historiografia apresentada neste trabalho (LIMA, 1974, p. 84; MENDES, 1970, p. 391; REIS, 1988, p. 21) afirma ter pelo menos as obras iniciadas nestes locais, a partir de 1686 (ver Ponta da Cidade e Ilha dos Barros figura 16).

Quanto à Paraty, interessante é destacar que, ao dizer que a mesma é defensável por natureza, provavelmente o autor do primeiro relatório referiu-se à questão da profundidade de seu porto, mais raso que o restante da região da Ilha Grande ${ }^{64}$.

Posterior a este último relatório, MENDES (1970, p. 394) diz que a última notícia encontrada a respeito das fortalezas angrenses é uma Provisão-Régia datada de 21 de julho de 1797, que manda ouvir o Governador sobre a conveniência de se ampliarem as fortificações do litoral da baía de Ilha Grande, porém, este documento não foi encontrado. Nas palavras deste autor, "daí pra cá, nos parece, nunca mais se fez qualquer obra na centenária fortaleza do Outeiro do Carmo (...)".

Entretanto, o governo colonial continuou a se preocupar com a defesa dos locais afastados da Baía, principalmente na região da llha Grande, incluindo Angra dos Reis, já que navios estrangeiros continuaram a fazer ali suas aguadas e a descarregar contrabando, apesar de maior presença das tropas regulares, a partir do século XVIII. E, ainda, segundo REIS, “(...) depois da independência os piratas fizeram diversas incursões, tentando desembarque, nas quais foram repelidos (...)" (1988, p. 22).

É importante lembrar que no século XIX temos a presença de corsários argentinos nessa região, como já dito inicialmente. Nas palavras de MELLO, "dada a insuficiência naval, seja de navios, seja de tripulação, por decreto de 2

\footnotetext{
${ }^{64}$ Nas palavras do Marquês do Lavradio, "(...) há um muito grande porto coberto com a ilha ou restinga da Marambaia, e com a llha Grande, de que lhe ficam três barras, ou três entradas, que são a mencionada da Guaratiba, a da Marambaia, e a do Cairoçú. As duas últimas são franca para a toda casta de embarcações, e armadas, que podem navegar interiormente por toda a parte, ancorar em todas as enseadas ou saccos, assim da llha Grande, como da terra firme, e junto das differentes ilhas que há n'aquelles portos até avistar a llha de Paraty; mas o porto ou sacco de Paraty só dá entrada a sumacas (grifo meu)" (Relatório do Marquês de Lavradio, 19 de junho de 1779 - Revista Trimestral de História e Geographia ou Jornal do Instituto Histórico Brasileiro, n. ${ }^{\circ} 16$, janeiro de 1843). Cabe lembrar aqui que sumaca pode ser definido como barco pequeno, de uma vela, como dito em nota anterior.
} 
de janeiro de 1826, o Governo argentino autorizou o corso contra o comércio marítimo brasileiro" (1987, p. 73).

Sobre os registros documentais da época, CAPAZ (1996, p. 165) afirma que entre 21 de abril e 01 de setembro de 1918, a Gazeta de Manuel Possidônio, ou seja, a Gazeta de Angra publicou uma série de cartas enviadas ao governo imperial pelo governador militar de Angra dos Reis e por outras autoridades de vilas vizinhas sobre a presença de corsários platinos em águas da Baía de Ilha Grande.

Apesar de realizado o levantamento documental nas devidas instituições, o conjunto de cartas publicadas não foi encontrado integralmente. Entretanto, três publicações ${ }^{65}$, nos permitiram acesso parcial a esses documentos que indicam a preocupação constante em defender a região, tendo como Governador Militar Manoel Joaquim Pereira da Silva, a partir de 1822. Conforme documento abaixo,

“(...) Manda o Príncipe Regente pela Secretaria de Estado dos Negócios da Guerra, participar o Brigadeiro Manoel Joaquim da Silva, que he por bem dispens-alo do destino que Ihe dera de Commandante das Armas da Província de Santa Catharina para continuar o Governo Militar de Ilha Grande e Paraty, ficando assim de nenhum effeito a nomeação do Brigadeiro de Engenheiros Antônio José Rodrigues e por tanto ordena que sem perda de tempo marche para o governo dos mencionados Districtos em cuja defesa deverá empregar a maior actividade, vigilancia e zelo que o caracteriza (...) (grifo meu)" 08/09/1822.

(Apud RAMECK, Maria José e MELLO, Diuner. Roteiro Documental do ACERVO Público de Paraty - 18011883, p. 79)

Dessa forma, percebemos que nas primeiras décadas do século XIX as forças imperiais opõem resistência. Segundo CAPAZ (1996, p. 165) as embarcações de guerra começaram a patrulhar a vila em 1827 e, na emergência, planejou-se até mesmo a construção de navios de guerra, com a colaboração dos habitantes da região, que conforme a documentação, forneceriam madeira e mão-de-obra, como se segue,

\footnotetext{
${ }^{65}$ RAMECK, Maria José e MELLO, Diuner. Roteiro Documental do ACERVo Público de Paraty - 1801-1883; REIS, Brasil dos. Apontamentos para a história de Angra dos Reis, 1988 e Revista do Ateneu Angrense de Letras e Artes, Ano V, nº 1.
} 
“(...) Com a chegada a este Vila fez ver a alguns habitantes a grande necessidade que havia pelo menos de uma barca canhoneira, que não só fizesse este porto mais respeitável, como servisse de socorro aos diferentes lavradores, que se acham com suas propriedades à beira-mar, e por isso mesmo mais expostos aos insultos de qualquer corsário, ou pirata. Esta medida é tão necessária que a experiência mostrou em 1801, um pequeno corsário espanhol fez prisioneiro a sete embarcações deste porto, e Paraty que se achavam fundeadas nas Palmas, algumas léguas distantes desta vila, à espera de monção sem Ihes poder prestar socorros, que muito aproveitariam, ainda sendo pequenos. Fazendo ver aos habitantes as dificuldades que havia de se não poderem presentemente construir no Arsenal da Marinha: a minha exposição foi muito bem recebida por aquelas pessoas a quem num pequeno espaço de tempo pude comunicar e todas estão prontas a prestaremse cada uma como for compatível com seus teres, e por isso desde já espero o melhor resultado, ainda quando não seja senão para as madeiras, e mão-deobra. Para melhor das princípio ao apresto das mesmas madeiras, sirva-se Vossa Excelência, merecendo a Imperial Aprovação de S. M. o Imperador, ordenar que o (...) Inspetor da Marinha me remeta quanto antes os moldes, que se acham feitos de tais barcas, para desde já por em prática os referidos cortes (...). Vila da Ilha Grande. Manoel Joaquim Pereira da Silva. Governador Militar (grifo meu)". 14/02/1826.

(Revista do Ateneu Angrense de Letras e Artes, Ano

$$
\left.\mathrm{V}, \mathrm{n}^{\circ} 1, \mathrm{p} .40\right)
$$

"(...) já recebi as formas e algumas instruções para os cortes da madeiras, por todo este mês pretendo-me achar restabelecido e dar princípio (...). Manoel Joaquim Pereira da Silva. Governador Militar (grifo meu)", 01/04/1826.

(Revista do Ateneu Angrense de Letras e Artes, Ano $\left.\mathrm{V}, \mathrm{n}^{\circ} 1, \mathrm{p} .41\right)$

Segundo este autor, o interesse era proteger com comboios as embarcações de carga, dando combate ao inimigo, impedindo sua aproximação e reforçando os fortes da vila, cujos canhões hoje são vistos na cidade e no Colégio Naval, como veremos adiante. Aqui ainda vale ressaltar que eram muitos os corsários e seus alvos preferidos eram canoas e pequenos barcos, que faziam tráfego de gêneros entre Paraty, Mangaratiba e a Corte. Os mesmos usavam de artimanhas, como a de navegar com as insígnias do Império Brasileiro nos mastros, para facilitar a aproximação de suas presas e, 
para preservar seus barcos, punham artilharia e tripulação em embarcações roubadas (CAPAZ, 1996, p. 166).

Sobre Angra dos Reis e regiões vizinhas, ainda, de acordo com este autor, em meados de 1827, a situação agravou-se muito ${ }^{66}$, a ponto de deixarem alarmados os comandantes das vilas litorâneas. Nesse sentido, eram tais os transtornos provocados pelos corsos à navegação da baía que o próprio comandante militar Manoel Joaquim Pereira da Silva oficiou ao Marquês de Maceió, as seguintes palavras,

"Para fazer subir à Augusta presença de S.M., o Imperador, que desta hora em diante considero estagnado o comércio de navegação desta vila, de Paraty e Mangaratiba, pois que nem pelo interior do país, nem em canoas (...) já podem mais negociar (grifo meu)", 28/08/1827.

(Apud CAPAZ, 1996, p. 171)

Para CAPAZ (1996, p. 173), a partir de 1828 as atividades de corso diminuem com o término das hostilidades entre Brasil e Argentina. Entretanto, a defesa da vila de Angra dos Reis continuou, contando principalmente com a Fortaleza do Carmo, que das fortificações citadas pela historiografia local (Carmo e São Bento e as que não foram concluídas, segundo estes autores, Ponta da Cidade e Ilha do Barros, mas que os documentos mostram que nem chegaram a ter suas obras iniciadas!), foi a que mais resistiu, conforme a documentação,

\begin{abstract}
"A Câmara Municipal desta Cidade reconhecendo continuar a necessidade de se manterem alguas peças do Forte do Carmo, a respeito do que já em 23 de janeiro e 6 de outubro do anno (...) a Vossa Excelência desconhecendo as cauzas de não ter sido attendida, leva novamente ao conhecimento de Vossa Excelência semelhante necessidade para que se sirva reclamar da autoridade competente as providências convenientes (...) (grifo meu)", 06/04/1838.
\end{abstract}

(Arquivo do Estado do Rio de Janeiro, Fundo: P.P. Notação 099, nº do maço: 06, Caixa: 0037)

\footnotetext{
${ }^{66}$ Especificamente contra a llha Grande, MELLO cita três ataques de corsários argentinos: o primeiro em 17 de maio de 1827, contra a Fazenda Dois Rios; o segundo em 23 de junho de 1827, na Ponta dos Castelhanos e o terceiro na Enseada das Palmas, em 19 de novembro de 1827 (MELLO, 1987, p. 73).
} 
A documentação indica que em 1850 a região do litoral sul fluminense ainda sofria com a presença de navios estrangeiros e se preocupava com a defesa da área. Assim como nos mostra a carta da Câmara Municipal de Paraty, que pedia reformas no Forte do Defensor Perpétuo, devido à presença dos ingleses na região e também a carta da Câmara Municipal de Angra dos Reis que demonstrava a sua preocupação referente à ordem do Governo Imperial de desarmar todas as fortificações. Os angrenses queriam o Forte do Carmo guarnecido, já que alegavam estar expostos a qualquer tentativa de invasão. Ambos os documentos apresentamos abaixo, respectivamente, "(...) a Câmara Municipal d'esta Cidade cuja vida e
prosperidade depende de seo comercio marítimo,
receosa de que os Ingleses, levados de sua hypocrita
philantropia, venão dentro deste Porto revistar, e
aprisionar os barcos de commercio licito, que n'elle
estejao ancorados, como tem acontecido em outros
lugares, sem que de terra ou do Forte Defensor ${ }^{67}$ se lhe
possa obstar, e nem ao menos proceder como em
Paranaguá, a Camara Municipal dirige-se a V. E. e pede
providencias promptas, para que as fortificações d'este
porto sejão postas na razão de defenderem de qualquer
pirataria que por ventura os Ingleses venhão cometter a

${ }^{67}$ Conforme Barreto, o Forte do Defensor foi reformado em 1822, no morro da Vila Velha em Paraty. Seu armamento constava de seis peças e, em 1831, foi desarmado e desguarnecido. Outras fortificações foram erguidas na região, a citar como exemplos, Forte de Iticopé, construído em época anterior à Independência, em 1822, foi ampliado e armado com duas peças; Bateria do Quartel, construída em 1822, teve pouca duração, Forte da llha das Bexigas, construído em 1818, localizado na llha das Bexigas, próximo à Paraty e Forte da Ponta Grossa, construído pelos portugueses antes da Independência, em 1822 foi melhorado e armado com dois canhões (1958, p. 217). Entretanto, sobre este último, ao fazermos o levantamento documental, encontramos o seguinte documento de 1826, "Tendo de se construir, como de effeito se vai dar principio no dia segunda-feira quatro do corrente mez, a hum Forte no lugar Ponta grossa, Districto d'estta Villa por ordem do llustríssimo Senhor Brigadeiro Governador Militar da mesma Manoel Joaquim Pereira da Silva, hoje me foi requizitada pelo Tentente Marcellino de Lima Rego, encarregado d'aquelle trabalho, huma canoa para a condução da Tropa, e mais Operários para o ditto effeito, a qual deverá estar prompta no dia quatro d'este mez, pela madrugada e sendo lhe a factura por se fazer muito necessária para o transporte da Tropa alli destacada (...) (grifo meu)". 02/12/1826, Apud RAMECK, Maria José e MELLO, Diuner. Roteiro Documental do ACERVO Público de Paraty - 1801-1883, p. 83. E, ainda, sobre o Forte do Defensor, cujo desarmamento foi atribuído ao ano de 1831 por Barreto, encontramos o seguinte documento de 1833, "em resposta ao Officio em q' requisita hum Official de Guarda Nacional, para Inventariar, e por em cautela os objectos da Fazenda Nacional q'se achão no Forte Defensor, em conseqüência do acordo q'tomára a Câmara Municipal desta Villa pela morte do Commandante do referido Forte (...) Em virtude do Officio que me foi dirigido (...) advertindo porem, q'alguns barris, em q'existe a pólvora, estão em máo estado por o cupido os ter dannificado. A chave da Caza de Pólvora existe em meo poder, faço mais sciente a V. S. para sua inteligência q'tdos os mais pretechos de Guerra e ferragens de carretas arruinadas, fica tudo na Salla do Quartel entregue ao Sargento do Destacamento (...) Manoel José da Silva, Major Commandante (...) (grifo meu)", 19/06/1833, Apud RAMECK, Maria José e MELLO, Diuner. Roteiro Documental do ACERVO Público de Paraty - 1801-1883 p. 83. 
tanto mais que elles estão a crusar esta barra, onde já revistaram um barco (...), as fortificações d'este porto (...) estão em completo estado de ruína; o Forte Defensor, que constitui a principal defeza (...) está sem caza e quartel, (...) porque tanto uma com outra cousa se abateo com as chuvas havidas ultimamente, as peças quaze todas estão encravadas e desmontadas, as faxinas arruinadas, não há armadilha, e nem pólvora alguma (...). E por isso a Câmara Municipal apressa-se em levar ao conhecimento de V. E. e respeitosamente solitia providencias promptas contra semilhante mal (...)", 12/08/1850.

(Apud RAMECK, Maria José e MELLO, Diuner. Roteiro Documental do ACERVO Público de Paraty - 1801-1883, p. 84)

\begin{abstract}
"Vendo a Câmara Municipal de Angra dos Reis que em conseqüência da Ordem do Governo Imperial vão ter dezarmadas as fortificações do litoral desta província e remetido seu material para o Arcenal de Guerra, mas sendo indispensável para a segurança e defesa desta cidade a conservação do Forte Actual, embora sem guarnição, porque a eventualidade de sua guerra marítima pode trazer a necessidade de novamente guarnecê-lo, senão para repelir (...) ao menos para impor respeito a qualquer um que tenta contra essa cidade, a qual por sua posição geographica e sua importância comercial está constantemente exposta a taes tentativas, que de certo se realizarão se em taes ocasiões não houver nesta cidade fortificação que lhe proporciona os meios de defesa; por isso, vem respeitosamente representar a Vossa Excelência, pedindo a conservação do Forte Actual no estado em que se acha, embora sem guarnição, ficando confiados alguma Authoridade ou pessoa de confiança de Vossa Excelência, o mesmo forte e os materiais nele existentes, para servirem quando for conveniente e necessário (...) (grifo meu)", 01/02/1860.
\end{abstract}

(Arquivo do Estado do Rio de Janeiro, Fundo: P.P. Notação 0102, n. ${ }^{\circ}$ maço: 01, Caixa: 0038)

Como dito anteriormente, MENDES (1970, p. 391) atribui o funcionamento do Forte do Carmo até o ano de 1873 e afirma que o Forte de São Bento, por ter sido construído muito próximo ao mar e sem nenhuma conservação, logo se arruinou e foi desguarnecido; sendo demolido pelo exército em 1835, quando ameaçava desabar. Entretanto, BARRETO (1958, p. 218), afirma que em 1838 este forte, assim como o do Carmo e o do Leme, 
eram comandados pelo Primeiro Tenente João Floriano de Oliveira. Então, como poderia este ter sido demolido em 1835?

Dessa forma, percebemos o quão conflitantes são as informações sobre as fortificações que defenderam a Vila de Angra dos Reis, não sendo possível atribuir a estas um período exato de funcionamento. Entretanto, os documentos históricos indicam que essa defesa contou, principalmente, com o Forte do Carmo, uma obra simples formada por duas baterias defensivas. Ainda por essa análise, podemos propor que as fortificações da Ponta da Cidade e da Ilha do Barros não chegaram a ser construídas, talvez por falta de pessoas ou também por falta de armamento, já que os relatórios indicam poucas peças de artilharia disponíveis em Angra dos Reis. Por mais que em Angra tenha havido poucas construções defensivas permanentes, a defesa pode ter sido formada por fortificações não permanentes, como é o caso do entrincheiramento feito na Praia do Carmo.

Quanto à relação entre as fortificações de Angra dos Reis e de Piraquara, a estratégia defensiva é similar, mas na primeira as baterias estão concentradas em locais estratégicos determinados, o que se denomina Forte. No segundo local, as estruturas não estão concentradas e sim distribuídas por toda enseada, de forma que fosse possível verificar a chegada de embarcações à longa distância, leste ou oeste, devido à existência de pontos de observação nos locais mais altos dos morros.

Para finalizar, uma informação que podemos dar com precisão é que, diferentemente do que afirma BARRETO (1958, p. 218), o Forte do Leme na Ponta Leste não foi contemporâneo ao Forte do Carmo, ao de São Bento e às baterias de Piraquara, pois sua construção enquadra-se em outro contexto histórico. Assim, se Piraquara, Angra dos Reis e Ponta Leste formaram um sistema defensivo, ou ao menos, um sistema de sinalização, este não contou com o Forte do Leme, mas pode ter contado com estruturas defensivas iguais as de Piraquara. Entretanto, antes de discutirmos este assunto, apresentamos a seguir os estudos realizados durante as etapas de campo em Angra dos Reis. 


\section{A etapa de campo em Angra dos Reis}

\section{O Forte do Carmo e o "túnel"}

Como veremos com mais detalhes no próximo item, este projeto executou três etapas de campo. Na primeira delas, visitamos os cartórios da cidade de Angra dos Reis, sua biblioteca municipal e os dois conventos que resistiram ao tempo: Convento do Carmo e o segundo Convento de São Bernardino de Sena. No primeiro, não foi possível ter acesso à documentação histórica, pelo fato que o mesmo estava passando por reformas em sua sede. Já, no segundo, não há documentação histórica e sim, somente a ficha dos canhões que se encontram na praça da cidade, que será apresentada no próximo item.

Convém aqui afirmar que a cidade de Angra dos Reis, hoje com mais de cem mil habitantes (FILHO, 2004, p. 12), tem o seu perímetro urbano totalmente ocupado, o que dificulta o desenvolvimento de pesquisas arqueológicas. Dessa forma, conversando com alguns moradores da região sobre as construções defensivas e outros monumentos históricos que resistiram até o momento, foi possível perceber que somente o bairro Morro da Fortaleza as pessoas fazem associação sobre a existência de uma fortificação em Angra dos Reis em tempos passados.

Fato contrário ocorre com a toponímia, pois ainda encontramos o Bairro de São Bento, ao lado do Morro de São Bento e o Morro de Santo Antônio, ao lado da segunda casa monacal dos franciscanos. O primeiro deles é uma área que hoje pertence ao Colégio Naval. Já o segundo, Morro de Santo Antônio, é uma área totalmente ocupada, ou seja, um bairro residencial.

Nesse sentido, por mais que o objetivo desta pesquisa seja indicar estruturas defensivas em Ponta Leste, área próxima à cidade de Angra dos Reis, na segunda e terceira etapas de campo, ocorrida em julho de 2007 e outubro de 2008, privilegiamos também a cidade, pois ainda há elementos que permitem o desenvolvimento de trabalhos arqueológicos na região.

Um desses elementos são os canhões que se encontram na Praça Amaral Peixoto, no centro da cidade desde a década de 1940, que veremos 
com mais detalhes no próximo item. Outro elemento é a associação que alguns moradores ainda fazem em relação à existência de uma fortificação na cidade, ou seja, o Forte do Carmo, no Morro da Fortaleza.

Dessa forma, não podemos deixar de descrever aqui a inspeção visual feita neste local. A partir da conversa informal com dois moradores ${ }^{68}$, que afirmaram haver vestígios deste forte (pilastras e uma capela) ainda no morro, fomos até o local. Ao indagarmos a outros moradores sobre os vestígios da fortificação, estes desconheciam sua existência. Interessante aqui destacar que um deles, que inclusive mora na Rua da Fortaleza (ver figura 20), disse o seguinte: "-Fortaleza, aqui tinha uma Fortaleza?". Mas este morador ao ser indagado sobre uma capela conseguiu nos indicar o local.

Chegando ao local (uma casa em reforma que será sede de uma Igreja de Nossa Senhora de Fátima), identificamos uma estrutura de pedra seca com terra, com 4,84 m de extensão e 1,08 m de altura, a $44 \mathrm{~m}$ de altitude (figura 21). Esta estrutura, ao que tudo indica, foi reaproveitada, pois em suas extremidades foram colocados dois blocos de cimento de mais ou menos $1 \mathrm{~m}$ de largura (figura 22). Acima destes blocos de cimento foram construídas duas pilastras de tijolo com cimento e, unindo estas pilastras, há um muro de tijolo vazado, que é base para uma pequena capela com a imagem da padroeira de Angra dos Reis: Nossa Senhora da Conceição da Ilha Grande (figuras 23 e 24).

Não podemos afirmar com exatidão se esta foi a área de construção do Forte do Carmo. Entretanto, apenas indicamos que moradores locais associam as histórias desta fortificação a este lugar (figura 25). Mas pelo material construtivo que compõe as pilastras e a capela é possível supor que a mesma não pertenceu ao Forte do Carmo, construído, provavelmente, no século XVIII. Dessa forma, caso alguma construção ali tenha pertencido à fortificação, esta não seria as pilastras e nem a capela, e, sim, a base de pedra seca que sustenta esta estrutura.

Além desta estrutura encontrada no Morro da Fortaleza, nos foi indicada a existência de um túnel histórico na cidade. Os moradores locais afirmam que essa construção seria a ligação entre a antiga fortificação do Carmo e o

\footnotetext{
${ }^{68}$ Um destes moradores, inclusive, afirmou que habitantes do local já encontraram balas de canhão no Morro da Fortaleza.
} 


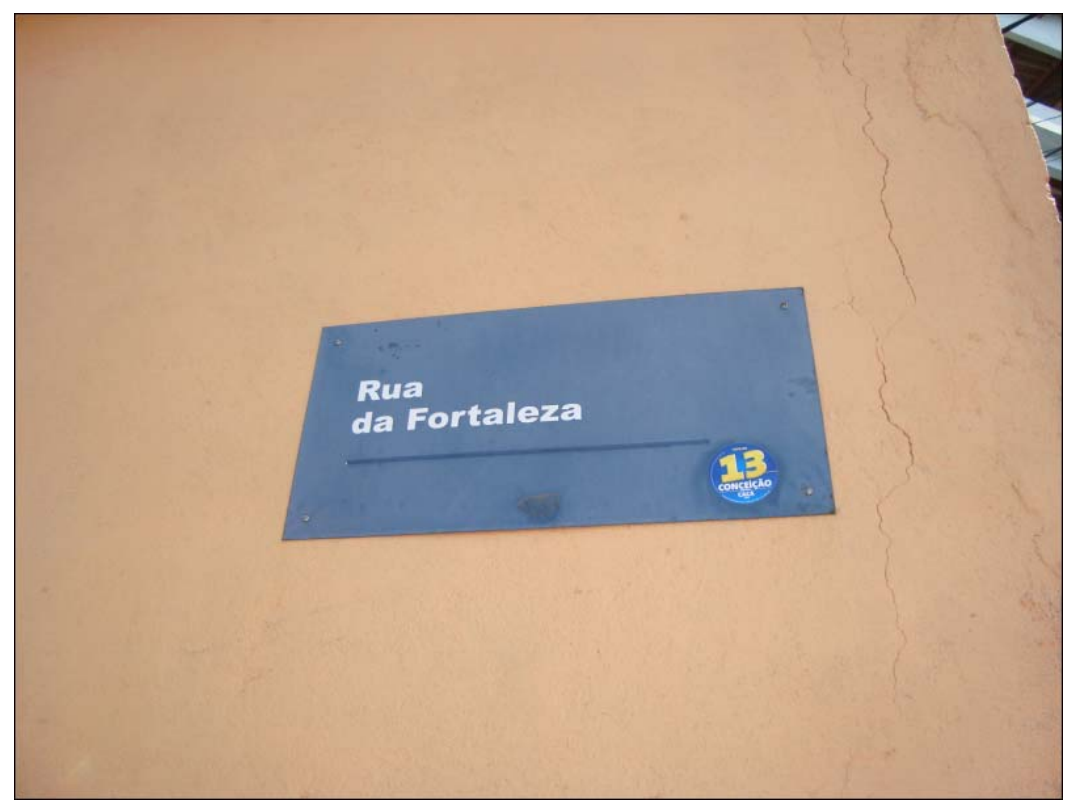

Figura 20 - Placa que indica a Rua da Fortaleza em Angra dos Reis

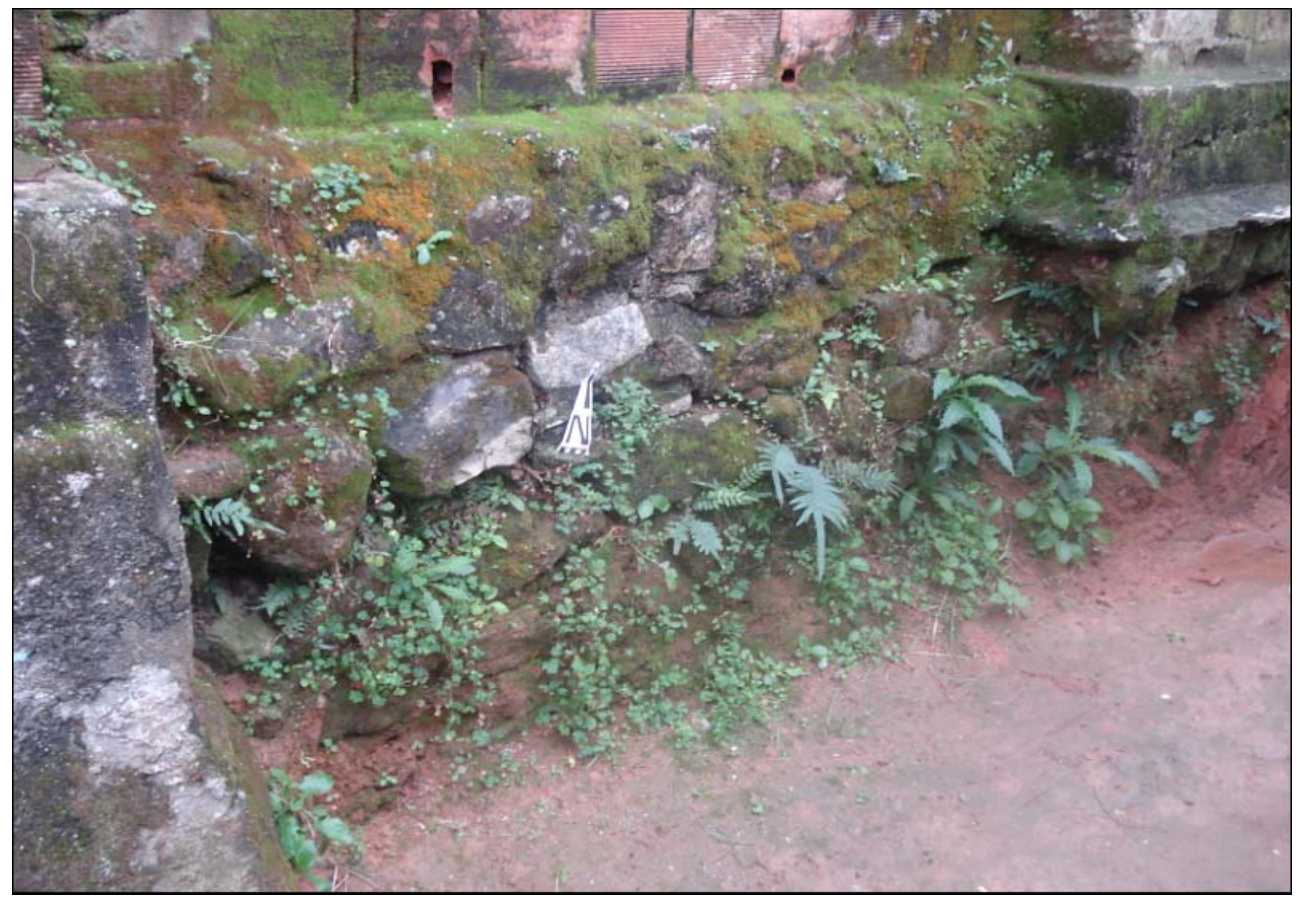

Figura 21 - Estrutura de pedra seca no Morro da Fortaleza 


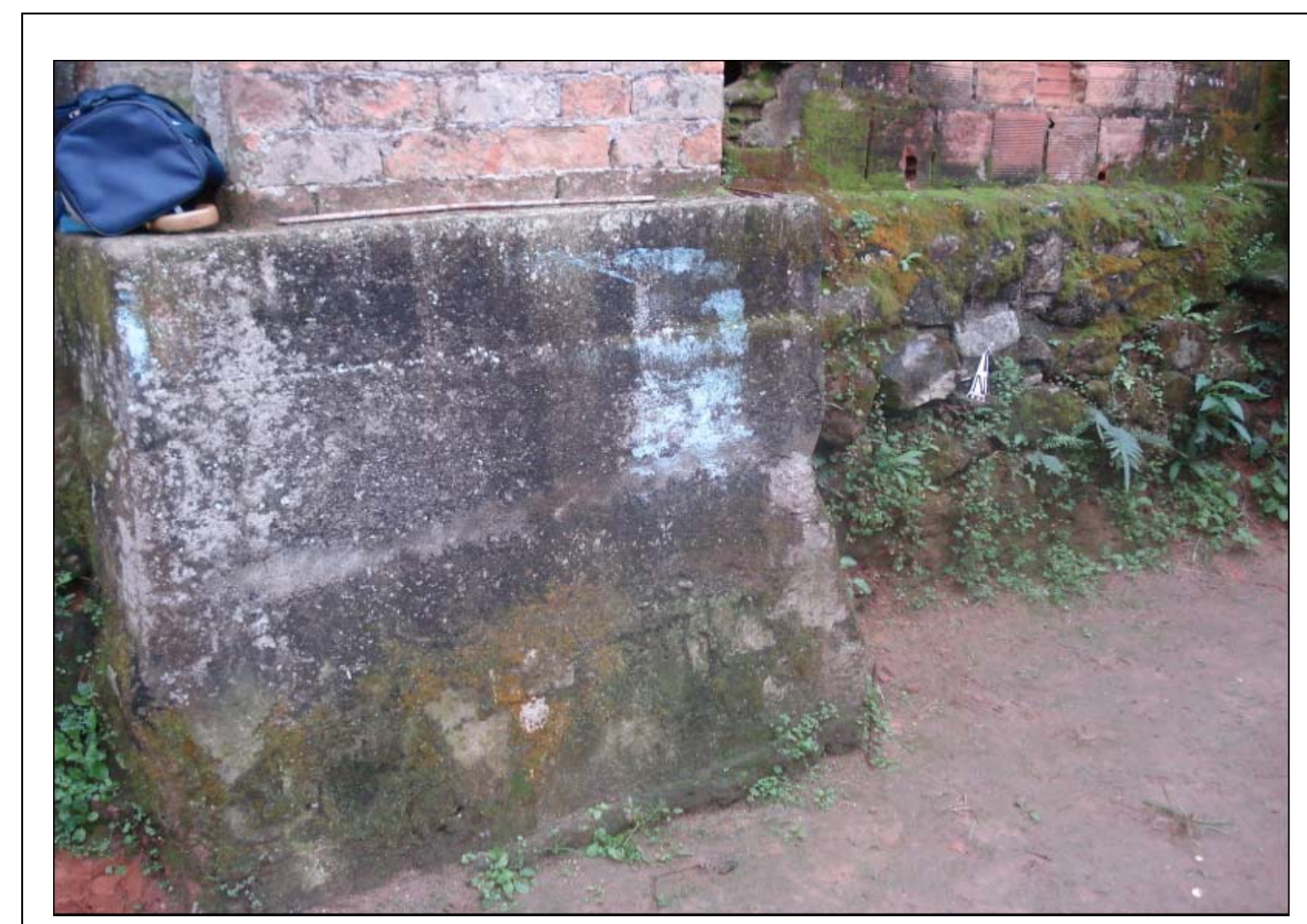

Figura 22 - Bloco de cimento

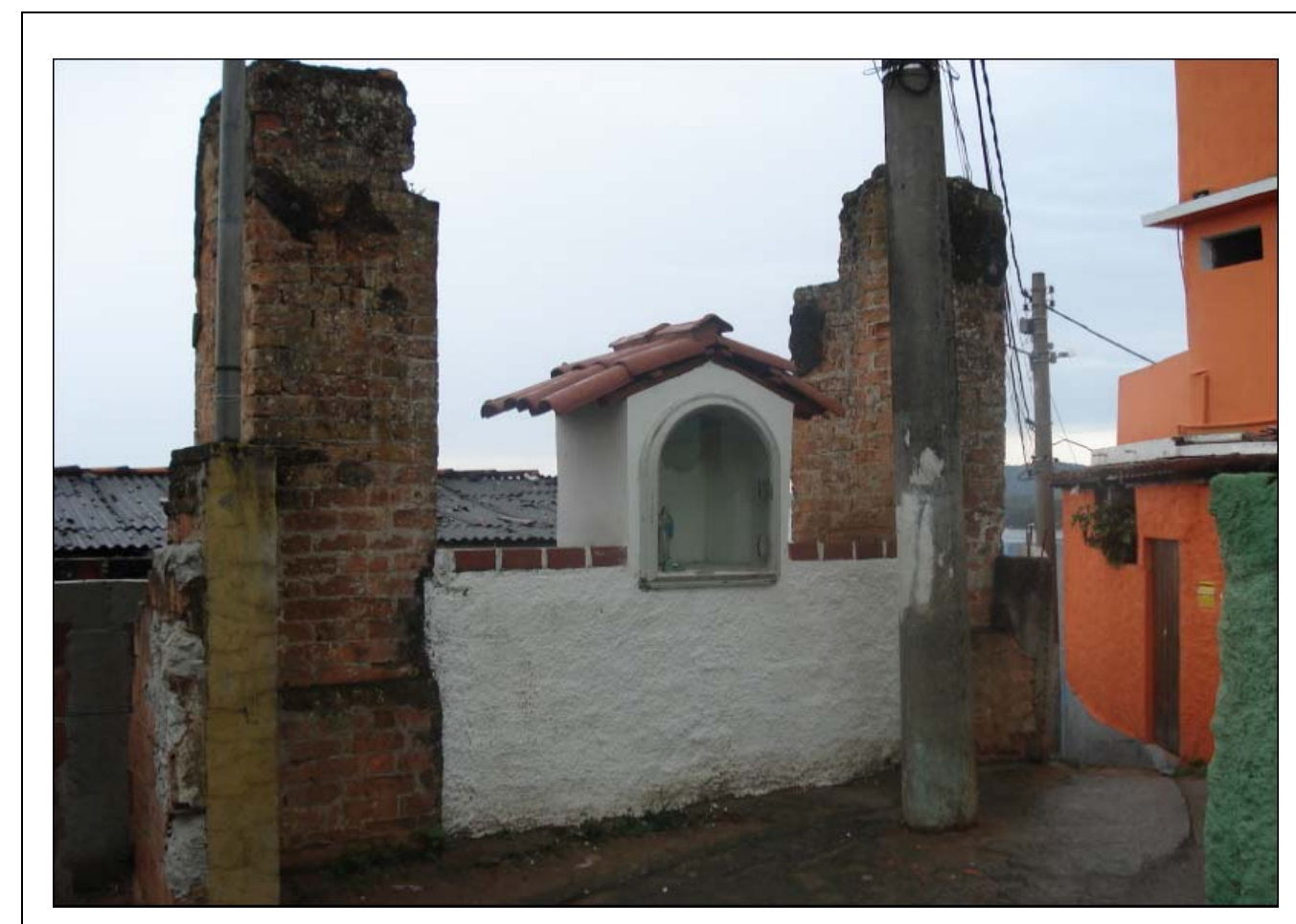

Figura 23 - Pilastras, muro e capela - parte da frente 


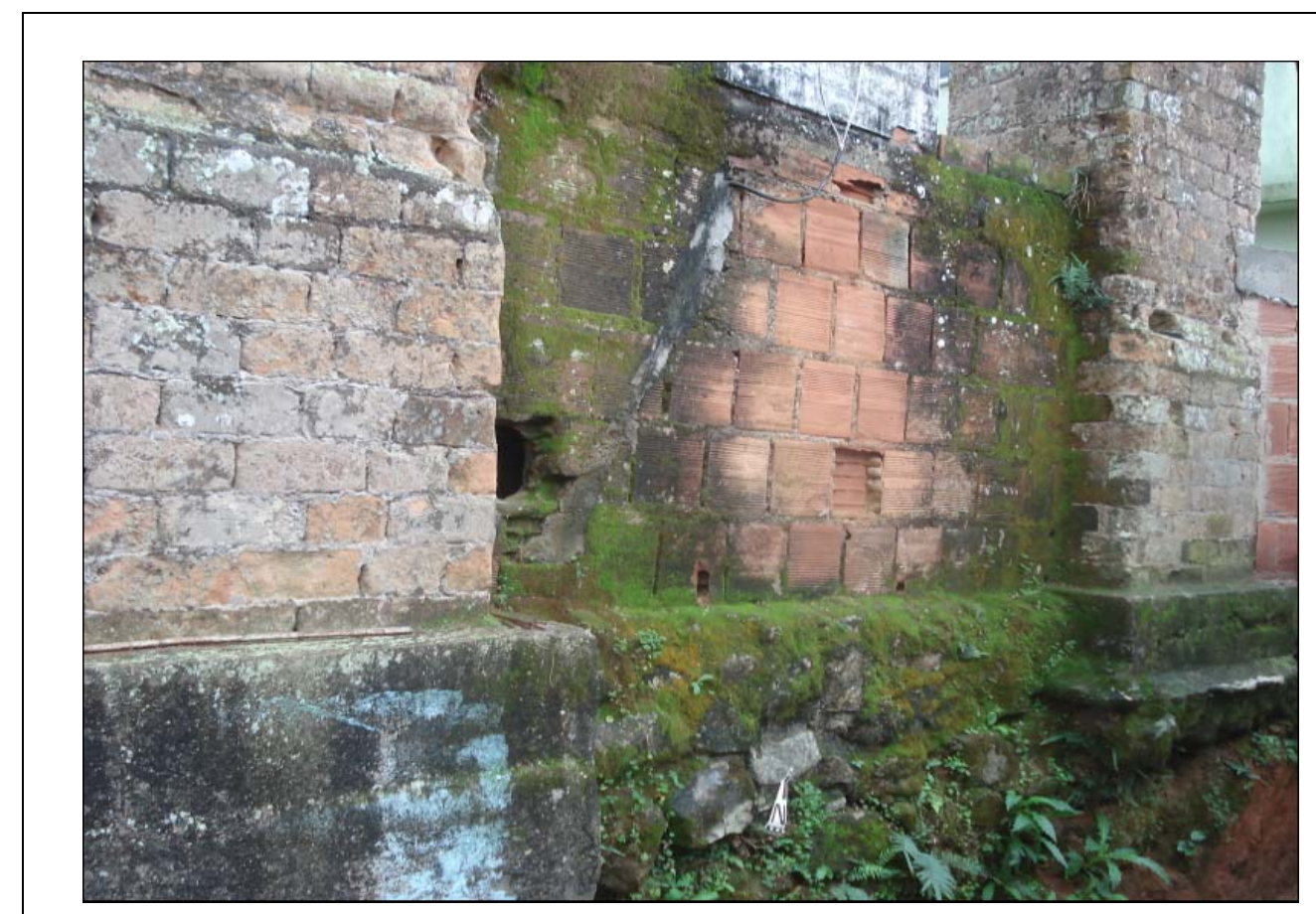

Figura 24 - Detalhe das pilastras e do muro parte de trás

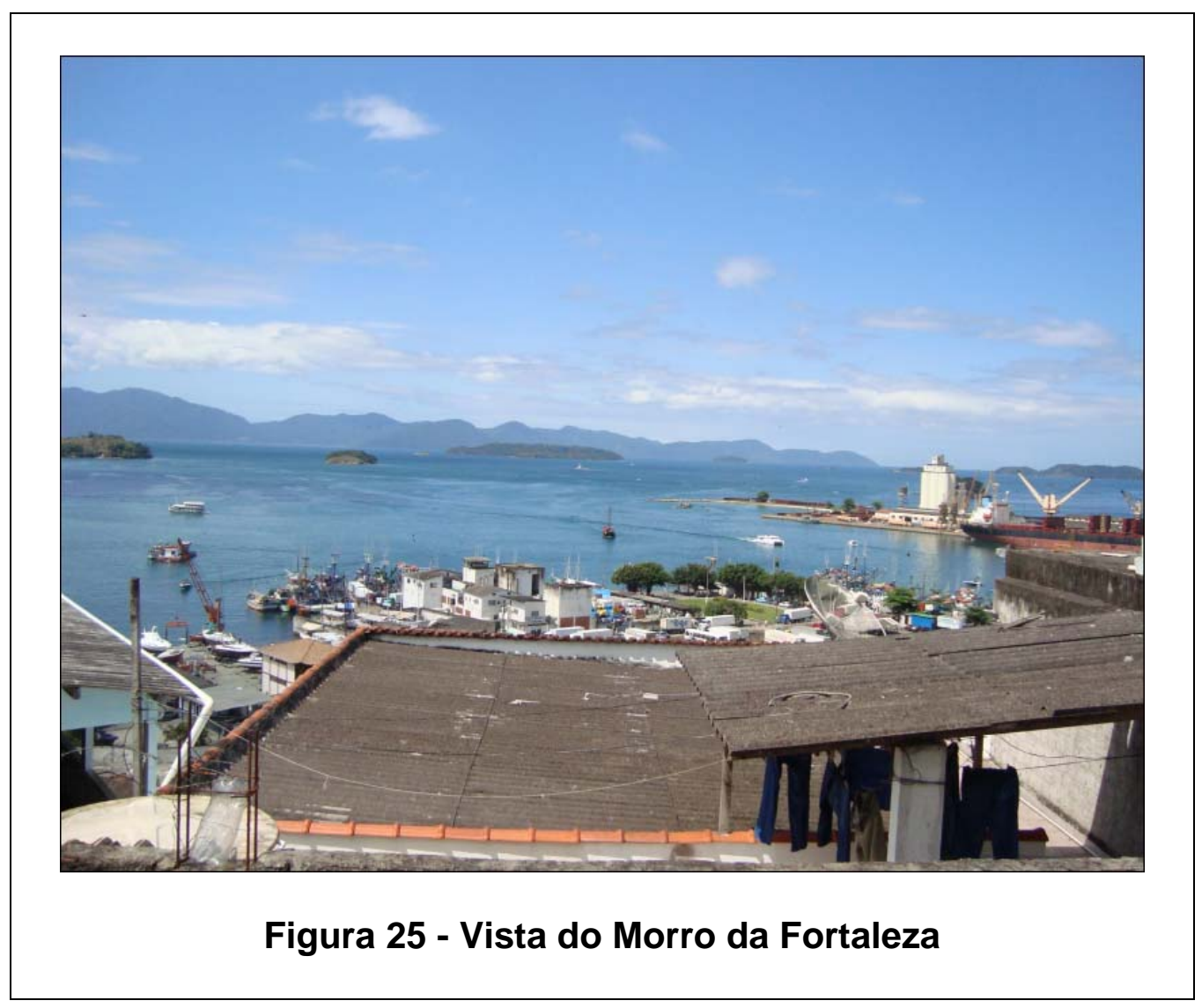


Convento de São Bernardino de Sena. Segundo notícia publicada na internet ${ }^{69}$, o túnel fora construído por escravos ligando o Convento de São Bernardino de Sena à Praia do Anil, desembocando abaixo do Morro da Fortaleza. Há aqueles que afirmam que a passagem era utilizada pelos religiosos como rota de fuga por ocasião de ataques de piratas e corsários estrangeiros. Em outra versão, o túnel serviria de acesso para o abastecimento do convento franciscano, visto que o mar avançava até bem próximo a sua desembocadura, o que facilitava o escoamento de mantimentos e matéria-prima.

$\mathrm{Na}$ terceira etapa de campo fizemos o reconhecimento desta estrutura, que foi implantada no sopé do Morro da Fortaleza. A mesma encontra-se em meio a residências próximas à Praia do Anil. É uma estrutura de pedras cortadas com argamassa que apresenta altura total de 3,90 m e largura de $4 \mathrm{~m}$. Para adentrar nesta estrutura há uma porta, hoje tampada com um pedaço de madeira, com aproximadamente 1,60 metros (figuras 26 e 27).

A vistoria em seu interior foi impossibilitada pela imensa quantidade de entulho, sendo difícil avançar mais de $5 \mathrm{~m}$ adentro (figura 28). É possível afirmar que o suposto "túnel" foi construído por meio de técnica e material construtivo diferentes daquele identificado anteriormente, cabendo aqui destacar, como dito, a presença de pedras cortadas com argamassa em seu exterior e tijolos no interior (figura 29). Entretanto, para apresentar detalhes sobre as estruturas identificadas serão necessários estudos mais detalhados, que podem ser temas de trabalhos arqueológicos futuros (figura 30).

${ }^{69}$ Consultado no site http://www.noticiapescada.com.br/colunas. php?id=90\&cat=3, acesso em 22/10/2008. 


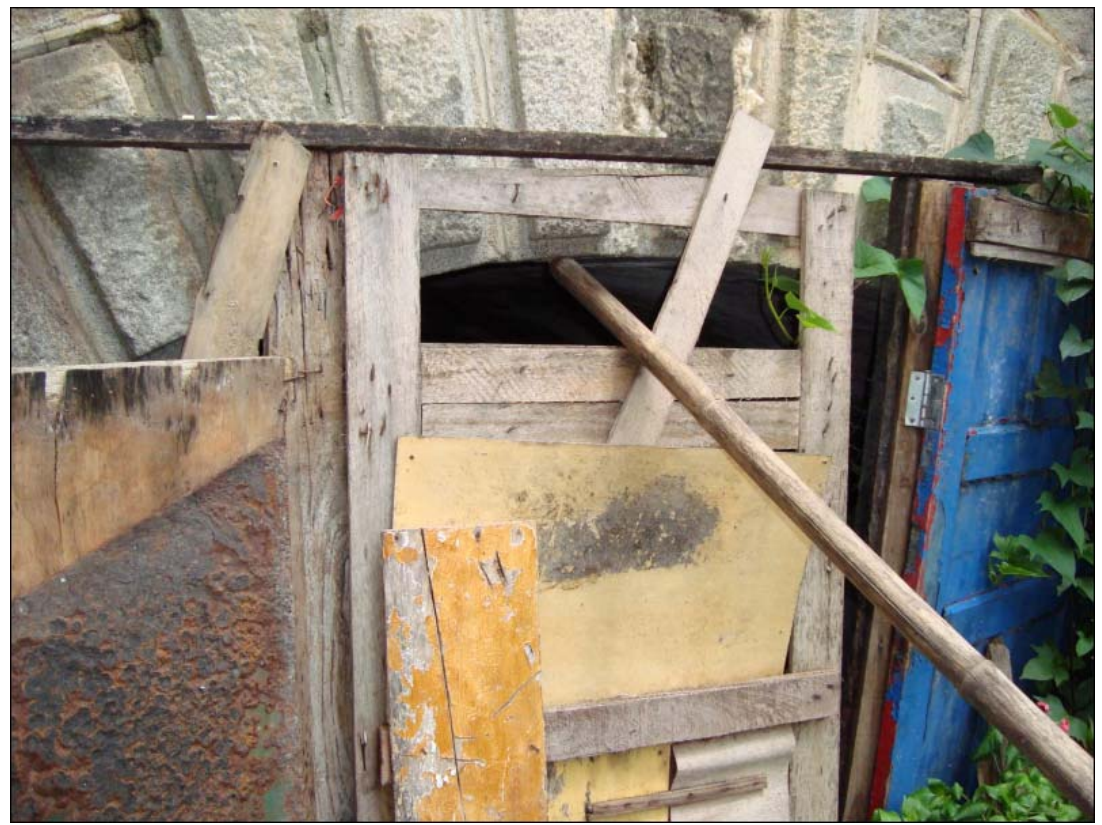

Figura 26 - Entrada do suposto túnel da Fortaleza

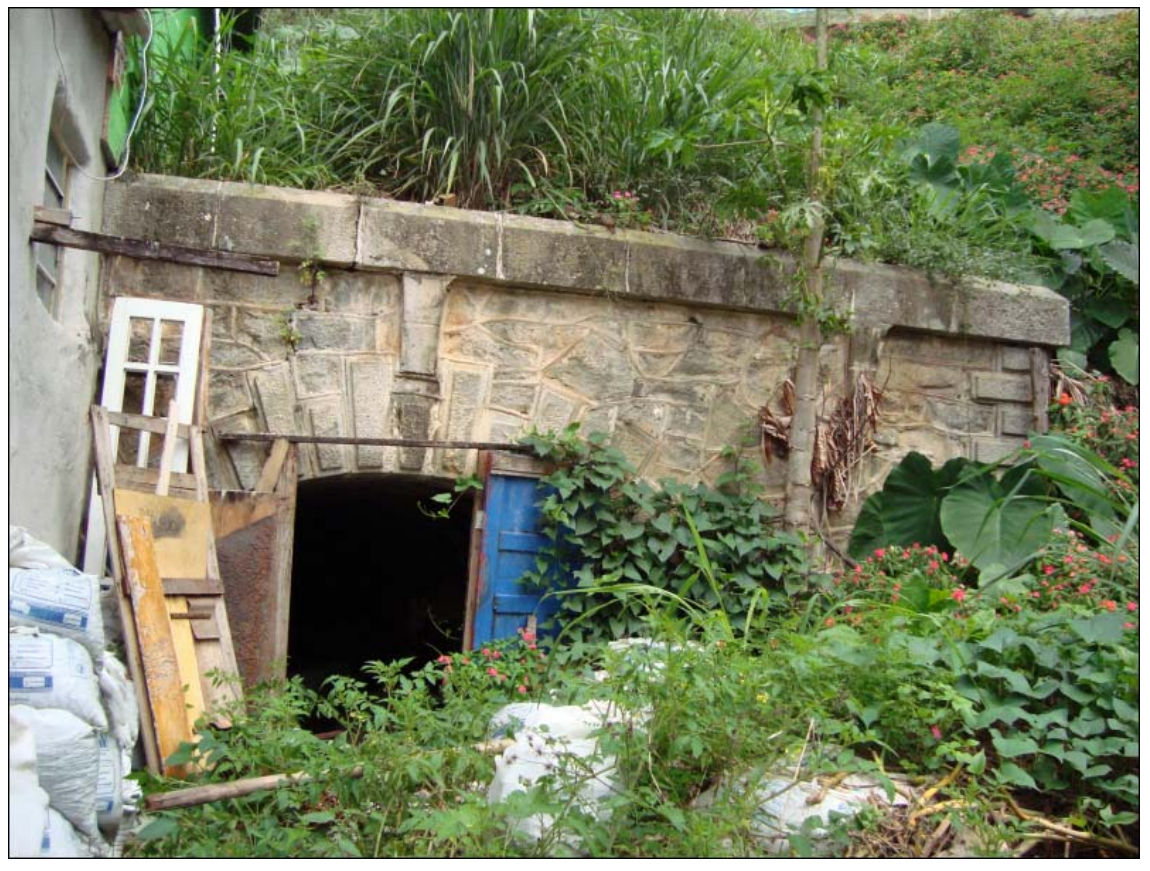

Figura 27 - Frente do "túnel" 


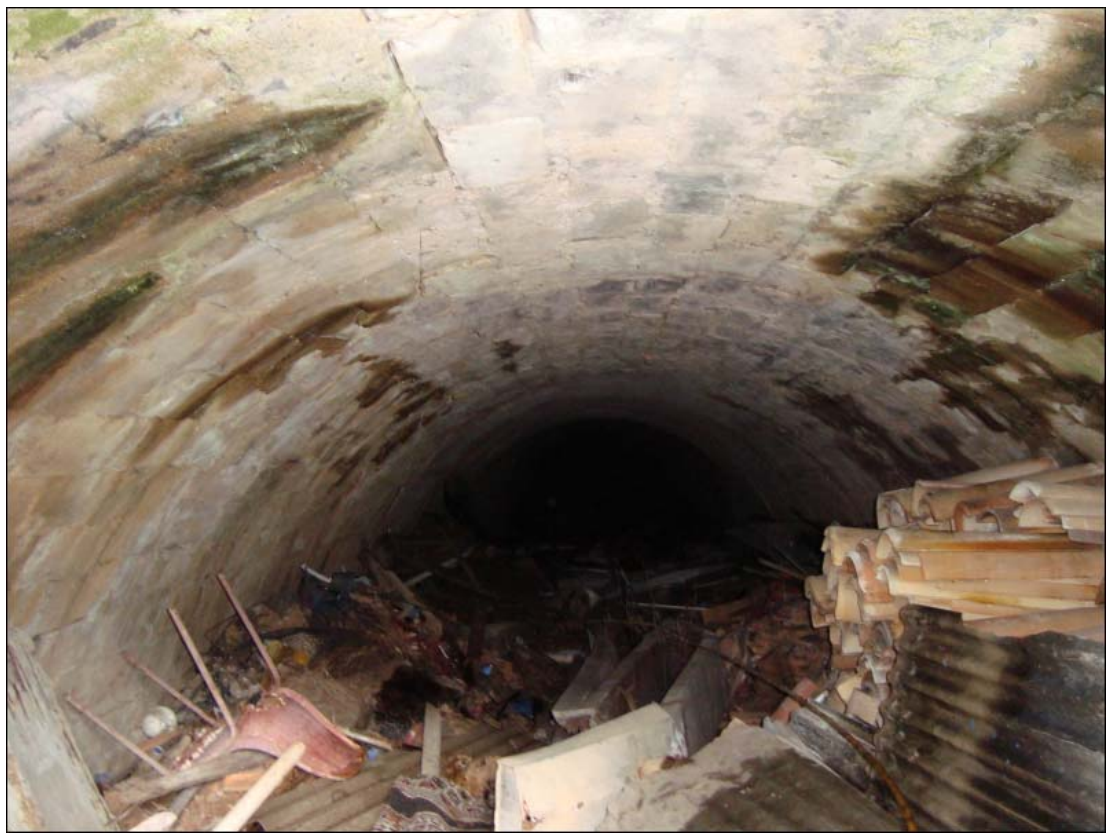

Figura 28 - Interior do "túnel"

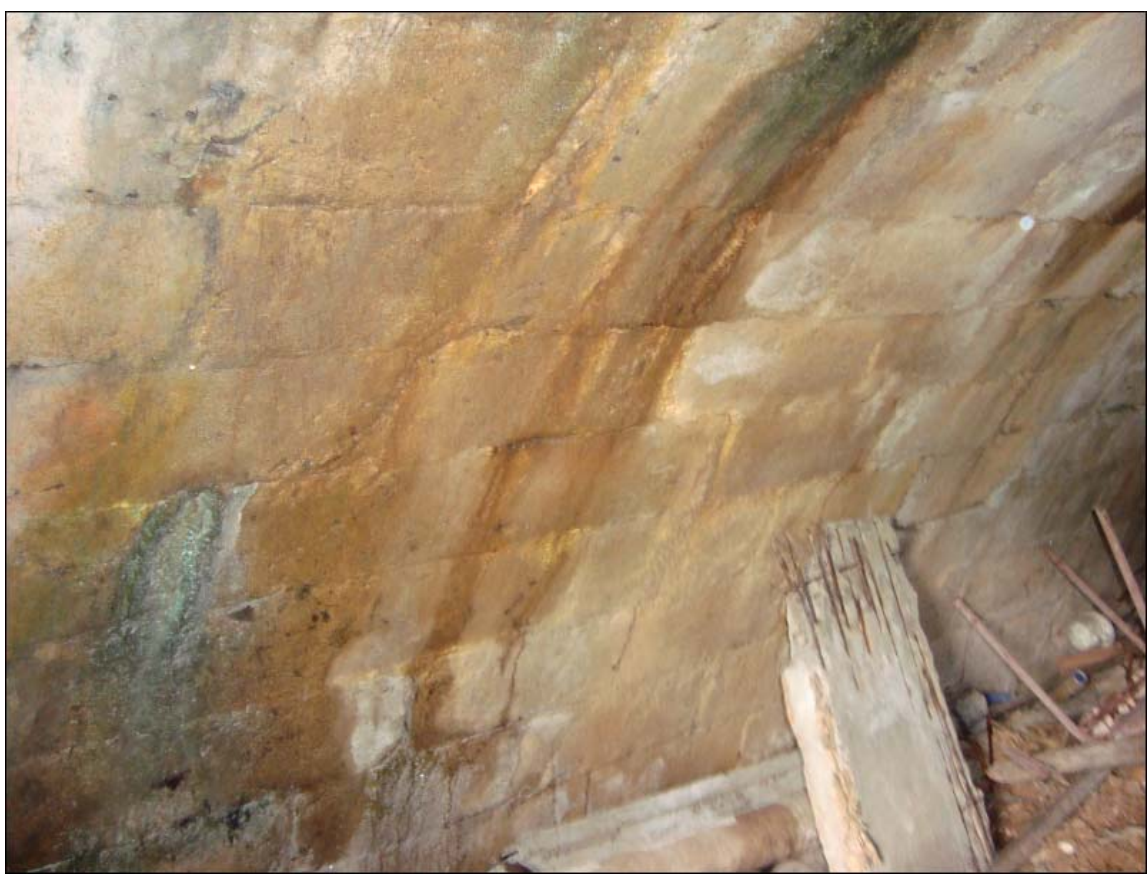

Figura 29 - Detalhe dos tijolos no interior do "túnel" 


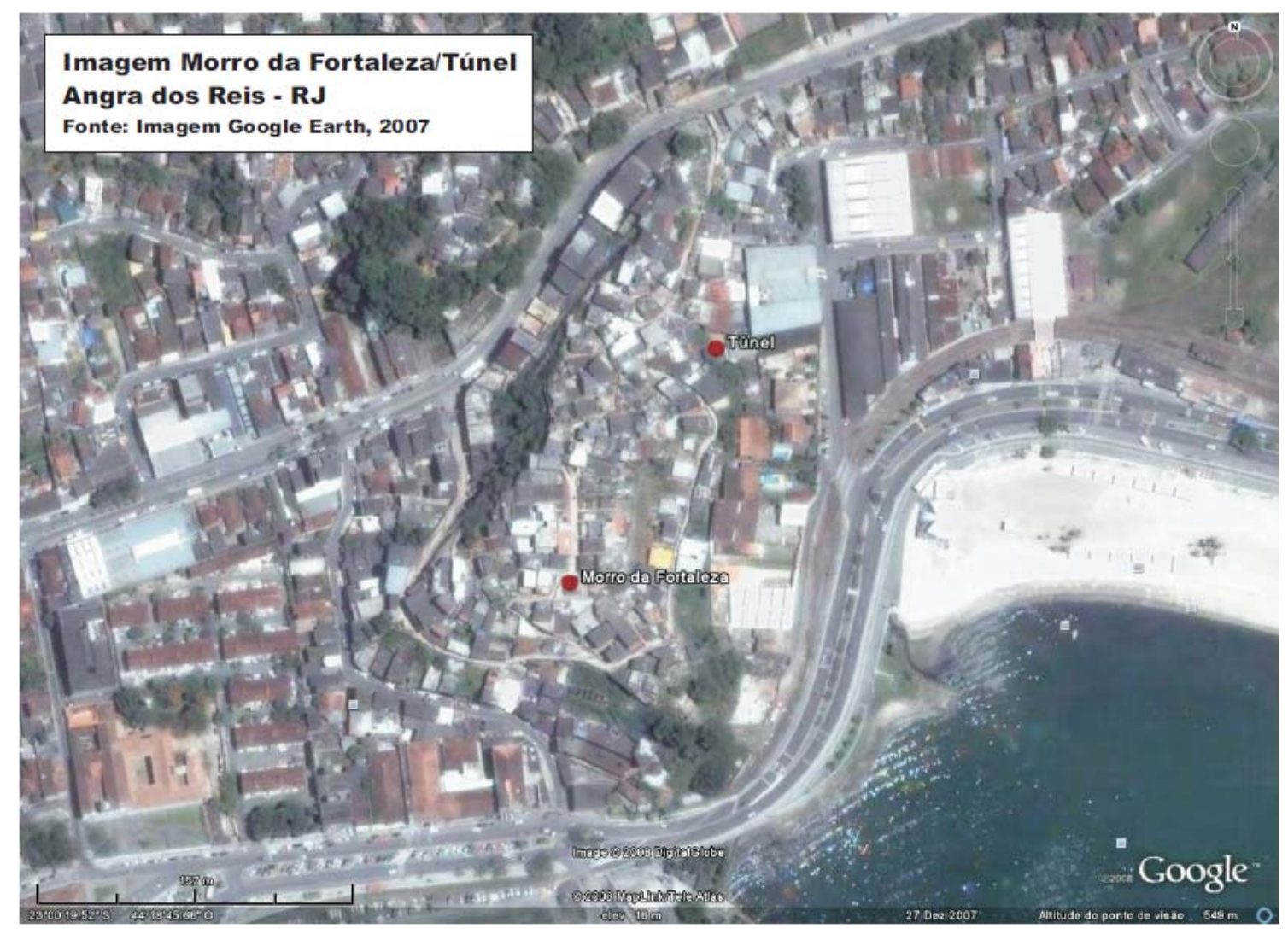

Figura 30 - Morro da Fortaleza e túnel 


\section{Os canhões}

Como apresentado no item sobre a defesa de Angra dos Reis, dois autores, LIMA (1974) e MENDES (1970), descrevem a artilharia presente nos Fortes do Carmo e São Bento: o primeiro diz que ambas as fortalezas estavam armadas com canhões de calibre 12, 18 e 24; já o segundo afirmou que a Fortaleza do Carmo foi armada com peças de calibres 18 e 24 e o Forte de São Bento com seis canhões de calibre 12, sendo que algumas dessas peças ainda se encontram na praça da cidade e no Colégio Naval. No entanto, aqui cabe fazer uma ressalva: os dois relatórios, apresentados no item sobre a defesa de Angra dos Reis, trazem informações diferentes, pois, os mesmos atribuem três peças de calibre 12 e quatro peças de calibre 6 ao Forte do Carmo e duas de calibre 9 e quatro de calibre 6 ao Forte de São Bento. Nesse sentido, aproveitamos a segunda etapa de campo para descrever as peças que permanecem na cidade.

Em primeiro lugar, ao visitarmos o segundo Convento de São Bernardino de Sena foi possível ter acesso a uma ficha, elaborada pela Prefeitura de Angra dos Reis, mais precisamente, pela Secretaria da Cultura, Esporte e Turismo, em 1995. Neste documento, no item "observação" há a seguinte descrição: "existem 3 no Colégio Naval. Uma esta no Museu Histórico o Inca e outro no Museu Histórico de Belo Horizonte outra Fortaleza de São Bento". 70 No item "dados históricos/exposições", há a indicação que estas peças pertenceram à Fortaleza do Carmo.

Ao analisarmos a ficha da Prefeitura de Angra dos Reis, a impressão que temos é que a mesma foi confeccionada a partir de um canhão, mas indicando que todas as peças, distribuídas em outros locais, são semelhantes. Dessa maneira, a peça em questão foi descrita da seguinte forma: "canhão de ante-carga para ser apoiado no reparo, tendo na boca uma bala esférica, tendo no reforço, em relevo, as iniciais "GR", George Rex, rei da Inglaterra". Outros itens, preenchidos neste documento, referem-se à época, século XVIII, origem, Inglaterra, procedência, Portugal.

\footnotetext{
${ }^{70}$ Os erros ortográficos da ficha foram mantidos.
} 
Ao que tudo indica houve uma mudança na distribuição dos canhões da cidade de Angra dos Reis. Atualmente, encontram-se quatro peças na Praça Amaral Peixoto e duas peças semelhantes a estas no Colégio Naval. Nesse sentido, elaboramos uma ficha para a descrição dos canhões, a partir do trabalho de CAMARGO (2002) e do Manual de Preenchimento da Ficha de Inventário Nacional de Material de Artilharia, 1999.

De um modo geral, esta ficha privilegia a descrição do calibre de cada peça, a partir da medida do diâmetro interno da boca, expresso em milímetros; o comprimento total da arma (medida da boca ao cascavel, expressa em centímetros); a largura, medida distal entre os munhões, o comprimento funcional ${ }^{71}$, expresso a partir da distância da boca ao ouvido da peça, calibres de comprimento ${ }^{72}$, que se obtêm através da divisão do comprimento funcional pelo calibre, ambos expressos em milímetros.

Outras características foram observadas nas peças, entre elas: o brasão, sendo possível por meio deste definir o padrão das peças, as inscrições, tanto no munhão esquerdo, quanto no direito, para identificar o fabricante da peça, a seqüência numérica gravada no primeiro reforço, para estimar o peso total da arma e, finalmente, as setas, que, como veremos adiante, indicam se a peça passou por testes e pela aprovação de uma comissão das armadas inglesas (ver figura 31).

Cabe aqui destacar que todas as peças apresentam características em comum: todas foram feitas para sítios ou praças fortes e, inclusive, para a utilização naval. Além disso, são de ferro, de antecarga ${ }^{73}$ e alma $\operatorname{lisa}^{74}$ e,

\footnotetext{
${ }^{71} \mathrm{O}$ comprimento funcional é obtido pela mensuração da alma da peça. Entretanto, caso isso não seja possível, temos que medir a distância entre a boca e o ouvido (ALVES Apud CAMARGO, 2002, p. 50).

${ }^{72}$ Esta medida é de extrema importância, pois influencia diretamente no funcionamento do canhão, através da balística interna da peça. Em geral, existe a crença popular que quanto maior a peça, maior será o seu alcance. No entanto, este fato é válido apenas para armas que usam propelentes químicos modernos. Mas isso não é correto em se tratando de pólvora negra, que gera, aproximadamente, o seu potencial em cerca de 18 calibres de comprimento (CAMARGO, 2002, p. 50).

${ }^{73}$ Armas de carregar pela boca.

${ }^{74} \mathrm{~A}$ alma dos canhões é definida da seguinte maneira, "vazio interior cilíndrico (...), destinado a receber a carga, resistir aos gases produzidos pela combustão da pólvora e dirigir o projétil" (Manual de Preenchimento...1999, p. 43). No entanto, a alma pode ser lisa ou raiada. Quando a alma é raiada significa que a mesma apresenta caneluras ou estrias abertas, tendo por fim guiar o projétil, ao mesmo tempo lhes imprime movimento de rotação em torno do seu eixo. Ao contrário da alma lisa, que não apresenta essas estrias ou caneluras. Por isso mesmo as peças de alma lisa não têm grande alcance ou precisão.
} 


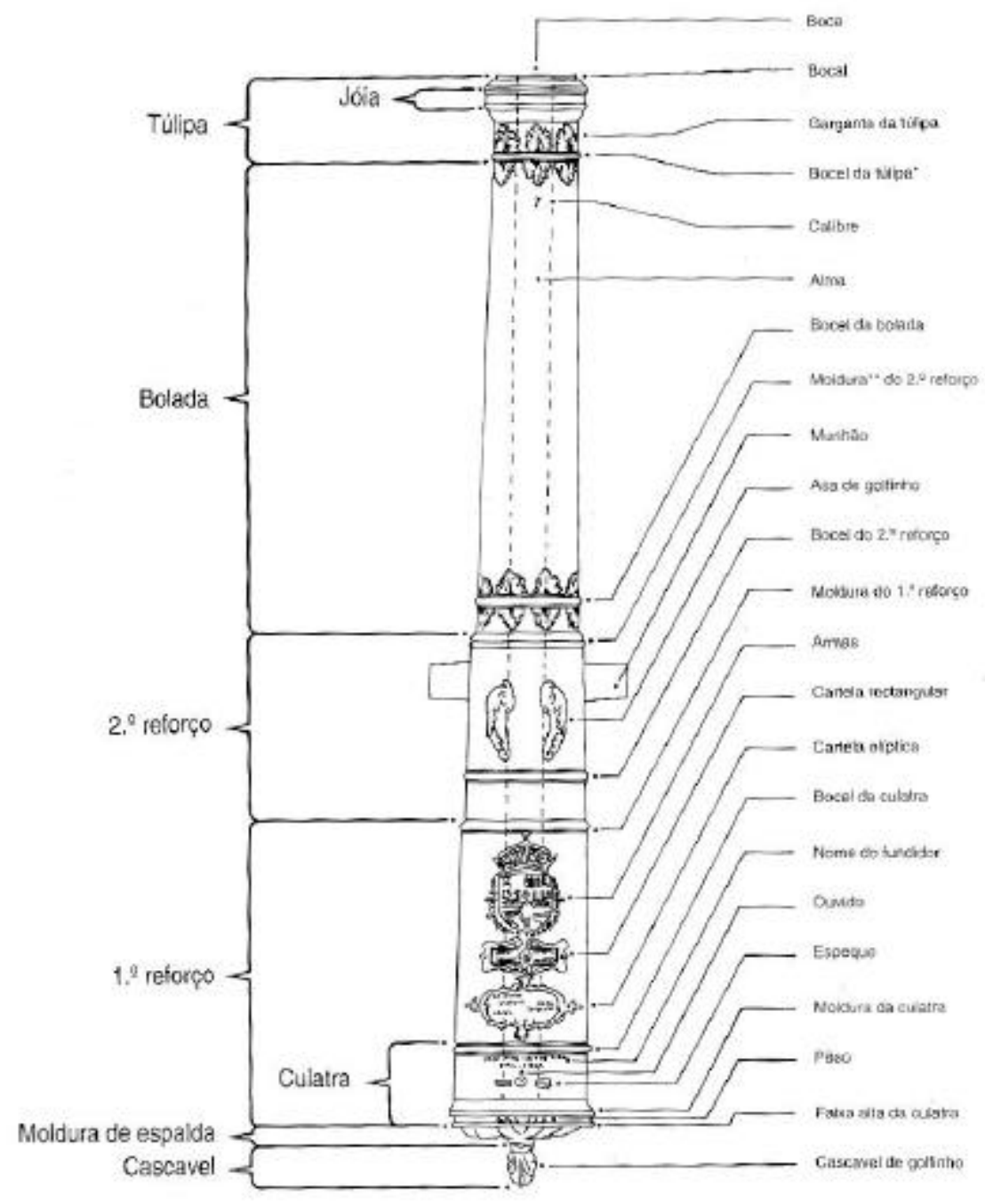

- Ossignaçào que, no sentido lato, inclui os filates lateraks " Designacio que, roste caso, inclui a faina e o cimbcio.

Figura 31 - Detalhes canhão 
segundo esses elementos, possuem um alcance médio de $2 \mathrm{~km}$ (Manual de preenchimento...., p. 32).

Nesse sentido, dos seis canhões existentes em Angra dos Reis ${ }^{75}$, três peças apresentam a inscrição $3 \mathrm{GR}$, gravada no segundo reforço, que indica a fabricação inglesa referente à época de George III (1760-1820). Esses canhões são do padrão Armstrong ${ }^{76}$ (dois deles estão na praça central e um no Colégio Naval).

A principal característica morfológica que define o padrão Armstrong, é a forma da culatra, repleta de frisos e molduras, elementos decorativos que desapareceram a partir de 1787. Em geral, os canhões Armstrong foram boas peças de artilharia, tributárias do desenvolvimento tecnológico de ponta. Entretanto, de 1792 a 1808, esses canhões foram sendo gradativamente descartados pela Inglaterra e, em muitos casos, os mesmos foram utilizados como postes de iluminação pública, hastes para a atracação, lastro de navios, marcos e monumentos. Mas em outros casos, continuaram a ser vendidos como artefatos militares. O Brasil foi parceiro da Inglaterra, no que diz respeito à compra destas peças. Baratos, esses canhões puderam ser adquiridos de carregação, equipando a maioria das fortificações brasileiras (CAMARGO, 2002, p. 54). Segue abaixo a ficha destes três canhões ${ }^{77}$.

\section{Canhão 1 - Praça de Angra dos Reis}

\begin{tabular}{|l|c|}
\hline Padrão & Armstrong \\
\hline Brasão & $3 \mathrm{GR}$ \\
\hline Inscrição Munhão direito & Ilegível \\
\hline $\begin{array}{l}\text { Inscrição Munhão } \\
\text { esquerdo }\end{array}$ & Ilegível \\
\hline Calibre (lb) & 12 \\
\hline Calibre & $117,42 \mathrm{~mm}$ \\
\hline Comprimento total & $251 \mathrm{~cm}$ \\
\hline Largura & $62 \mathrm{~cm}$ \\
\hline Comprimento funcional & $211 \mathrm{~cm}$ \\
\hline
\end{tabular}

\footnotetext{
${ }^{75} \mathrm{Na}$ terceira etapa de campo foi realizada uma pesquisa sobre o histórico destes canhões nos órgãos responsáveis pelo Patrimônio da cidade, porém não obtivemos resposta. As únicas informações adquiridas é que os mesmos estão expostos desde a década de 1940 e que não passam pelos cuidados necessários para sua conservação.

${ }^{76} \mathrm{O}$ padrão Armstrong foi estabelecido em 1727 e utilizado durante os reinados de George II (1727-1760) e parte do reinado de George III (1760-1820). Em geral, os canhões encontrados no Brasil apresentam os brasões destes dois reinados (CAMARGO, 2002, p. 58).

77 Os canhões foram numerados número 1, 2, 3 e 4 da Praça de Angra dos Reis e canhões números 5 e 6 do Colégio Naval. Os canhões de padrão Armstrong são, nesse sentido, os números 1 e 4 da Praça de Angra dos Reis e o canhão 5 do Colégio Naval. A numeração destes canhões obedeceu ao seu posicionamento geográfico, de oeste para leste, em relação ao mar (figuras 32 e 33).
} 


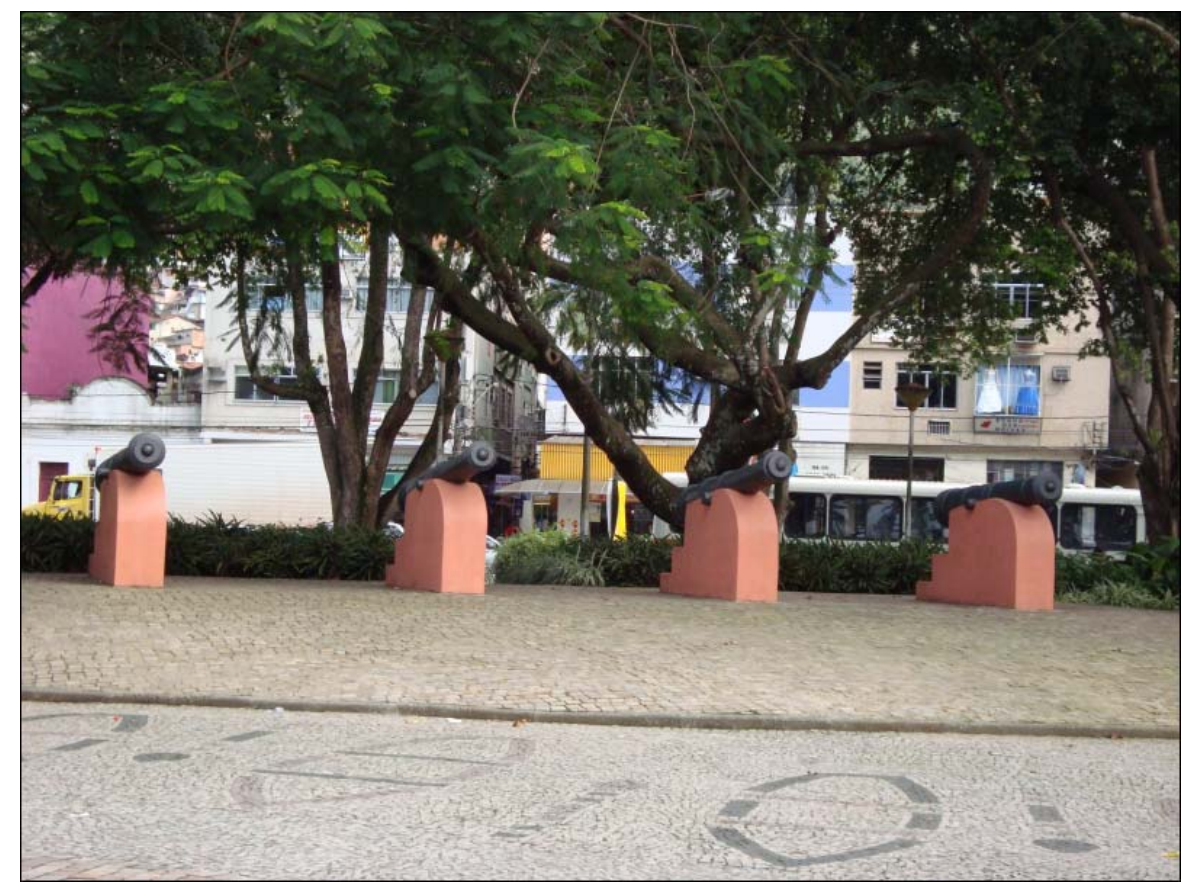

Figura 32 - Canhões Praça de Angra dos Reis (numeração da esquerda para direita)

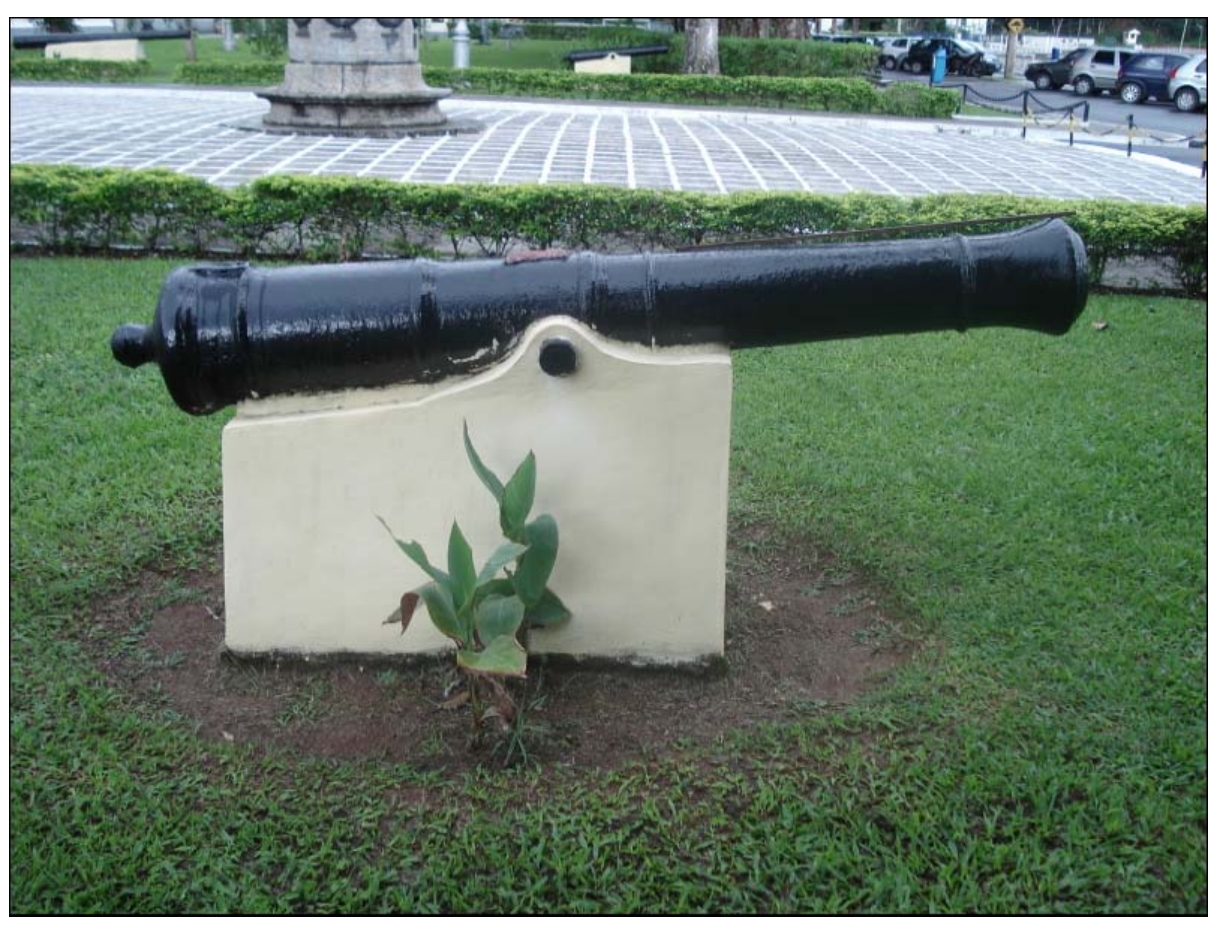

Figura 33 - Canhões Colégio Naval (à frente, canhão n..$^{\circ}$, ao fundo, canhão $n .^{\circ}$ 6) 
Sobre esta peça (figura 34), é difícil afirmar seu fabricante, pelo fato dos munhões estarem ilegíveis. Entretanto, a mesma apresenta a palavra SOLID na moldura da culatra (figura 35). No mesmo local há uma outra inscrição, porém quase ilegível. Como ocorreu em um dos canhões do litoral norte paulista, estudados por CAMARGO (2002), a inscrição SOLID indica que a peça foi brocada, ou seja, foi feita uma peça inteiriça e depois perfurado o tuboalma, sendo esta técnica usada a partir 1775.

Sobre suas características gerais, como dito, a peça é inglesa, de padrão Armstrong, referente à época de George III. A seqüência numérica gravada no primeiro reforço, 2911 , indica que a mesma tem uma massa igual a $1.484 \mathrm{~kg}$ (figura 36). Importante aqui destacar que essa seqüência muitas vezes é confundida com a data da fabricação da peça (CAMARGO, 2002, p. 55). Mas ao contrário disso, a mesma expressa os valores referentes aos quintais $(50.736 \mathrm{~kg})$, arrobas $(12.684 \mathrm{~kg})$ e libras $(0.453 \mathrm{~kg})$.

Nesse sentido, para calcular a massa da peça é preciso multiplicar os valores referentes a cada medida e depois somá-los. No caso deste canhão temos o seguinte cálculo: 29 × 50.736=1471,3; 1 × 12.648=12,648; $1 \times 0,453=$ 0,453 . O peso da peça é a soma destes resultados, ou seja, o total é $1.484,4$ $\mathrm{Kg}$.

Quanto às setas, uma única seta gravada no primeiro reforço significa que aquela peça havia sido testada e aprovada por uma comissão de testes das forças armadas inglesas (CASTRO e ANDRADA Apud CAMARGO, 2002, p. 57). No entanto, é importante aqui dizer que Thomas Blomefield foi encarregado de formar uma segunda prova de todos os canhões da armada inglesa, sendo que esta prova terminou em 1796. Nesse sentido, todos os canhões aprovados neste segundo teste levam a marca de uma segunda seta, logo abaixo da primeira (CAMARGO, 2002, p. 57). Este é o caso desta peça, que apresenta duas setas no primeiro reforço (figura 37). Há ainda uma terceira seta no cascavel, mas desta não encontramos referências (figura 38).

\section{Canhão 4 - Praça de Angra dos Reis}

\begin{tabular}{|l|c|}
\hline Padrão & Armstrong \\
\hline Brasão & $3 \mathrm{GR}$ \\
\hline
\end{tabular}




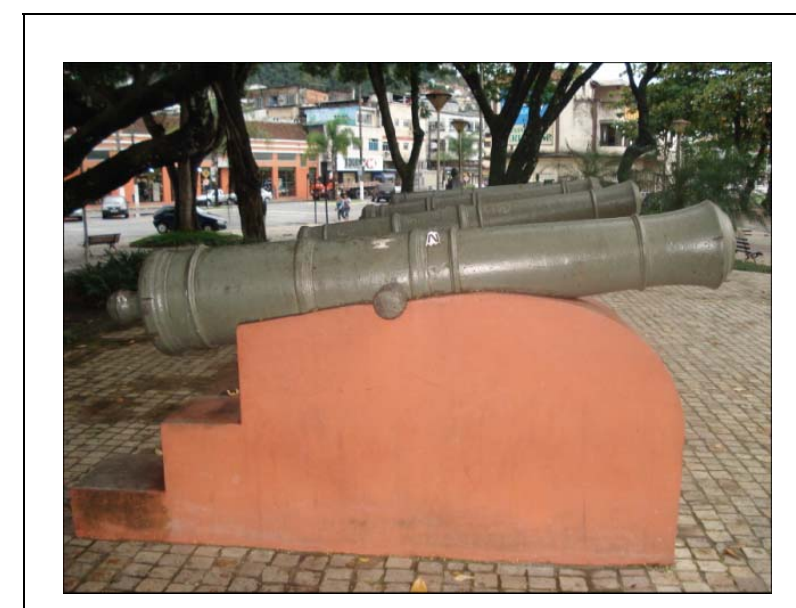

Figura 34 - Perfil canhão 1 Armstrong

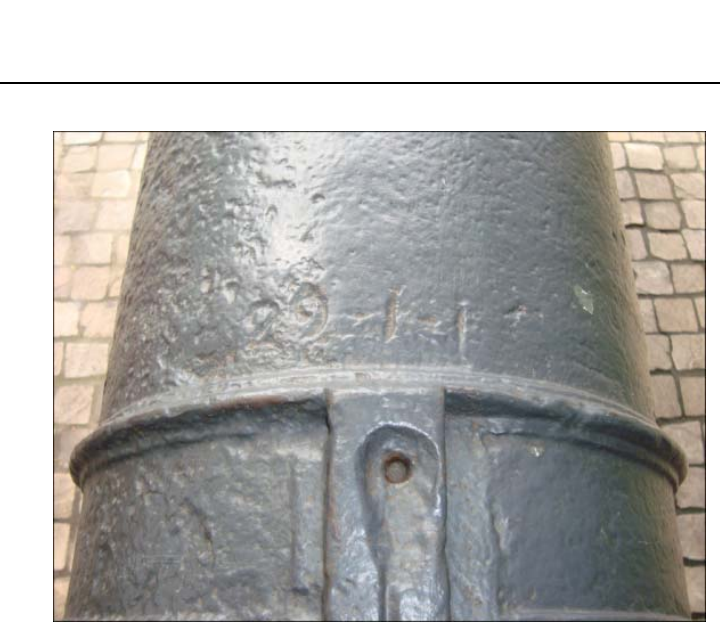

Figura 36 - Seqüência gravada no $1^{\circ}$ reforço

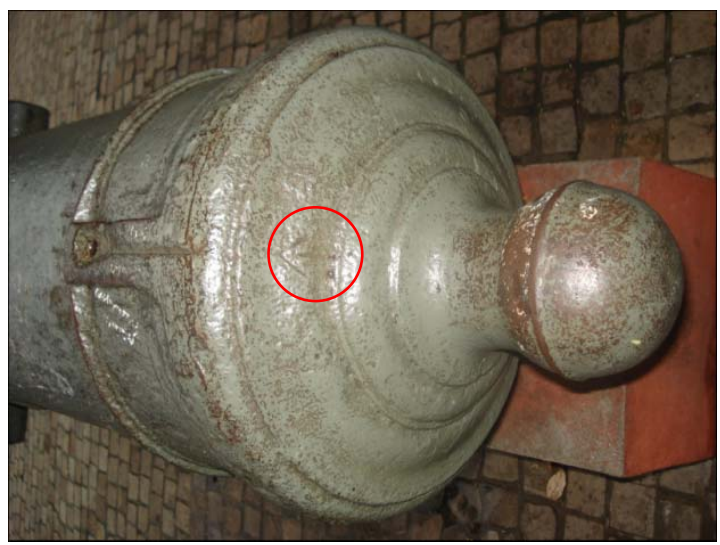

Figura 38 - Terceira seta

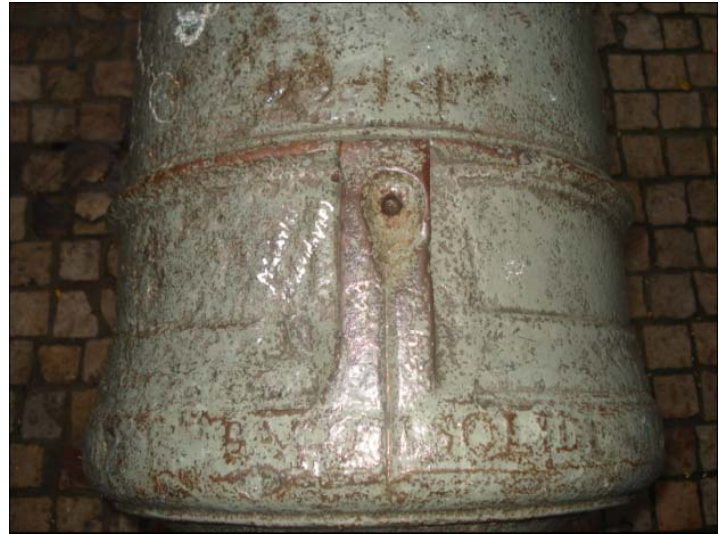

Figura 35 - SOLID na moldura da culatra

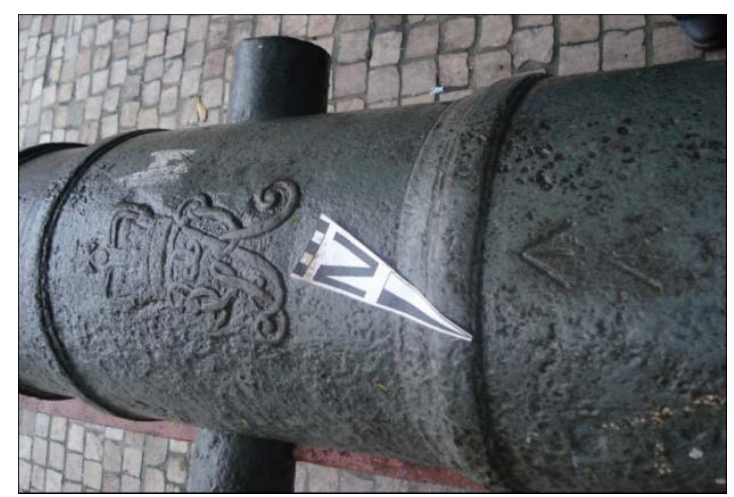

Figura 37 - Brasão 3 GR e duas setas

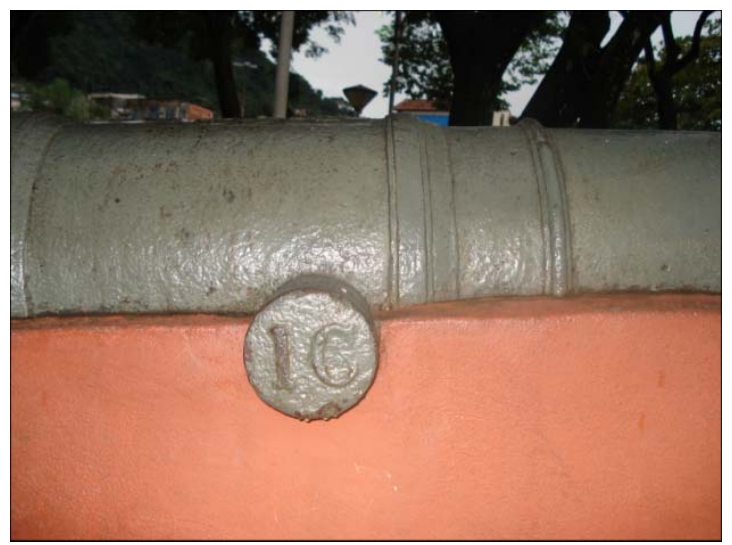

Figura 39 - Munhão direito canhão 4 


\begin{tabular}{|l|c|}
\hline Inscrição Munhão direito & IC (relevo) \\
\hline $\begin{array}{l}\text { Inscrição Munhão } \\
\text { esquerdo }\end{array}$ & 24 (batido) \\
\hline Calibre (Ib) & 12 \\
\hline Calibre & $117,42 \mathrm{~mm}$ \\
\hline $\begin{array}{l}\text { Comprimento total da } \\
\text { peça }\end{array}$ & $251 \mathrm{~cm}$ \\
\hline Largura & $60 \mathrm{~cm}$ \\
\hline Comprimento funcional & $211 \mathrm{~cm}$ \\
\hline Calibres de comprimento & 18 \\
\hline
\end{tabular}

Sobre este canhão, o mesmo apresenta no seu munhão direito a inscrição IC, que se refere à sigla de seu fundidor John Cookson, da cidade de Whitehill, Inglaterra (figura 39). Este fundidor passou a fornecer esse tipo de peça a partir de 1777 e, como ocorre com um canhão analisado por CAMARGO (2002), no litoral norte paulista ${ }^{78}$, esta peça apresenta o número 24 no munhão esquerdo, que ainda não pode ser decifrado (figura 40). Pelo nome do fabricante, a datação absoluta da mesma está entre os anos de 1777 1792 (CAMARGO, 2002, p. 60).

O canhão apresenta a seqüência numérica 28315 e, a partir do cálculo, uma massa correspondente a 1.468,5 kg (figura 41). Há ainda uma seta no primeiro reforço, indicando o seu teste e aprovação nas armadas inglesas. Cabe ainda ressaltar que, logo abaixo do brasão, há o número 11 (figura 42), que pode talvez indicar a posição que esta arma ocupou em embarcações portuguesa ou inglesa (CAMARGO, 2002, p. 59).

\section{Canhão 5 - Colégio Naval}

\begin{tabular}{|l|c|}
\hline Padrão & Armstrong \\
\hline Brasão & $3 \mathrm{GR}$ \\
\hline Inscrição Munhão direito & llegível \\
\hline $\begin{array}{l}\text { Inscrição Munhão } \\
\text { esquerdo }\end{array}$ & $\mathrm{S}$ \\
\hline Calibre (lb) & 12 \\
\hline Calibre & $117,42 \mathrm{~mm}$ \\
\hline $\begin{array}{l}\text { Comprimento total da } \\
\text { peça }\end{array}$ & $248 \mathrm{~cm}$ \\
\hline Largura & $47 \mathrm{~cm}$ \\
\hline Comprimento funcional & $214 \mathrm{~cm}$ \\
\hline Calibres de comprimento & 18 \\
\hline
\end{tabular}

Como demonstrado, o canhão 5 do Colégio Naval também é do padrão Armstrong. O seu munhão esquerdo apresenta a inscrição $S$, que talvez pode

${ }^{78}$ O canhão SP - SS - 07 apresenta o número 33 no munhão esquerdo (CAMARGO, 2002, p. $59)$. 


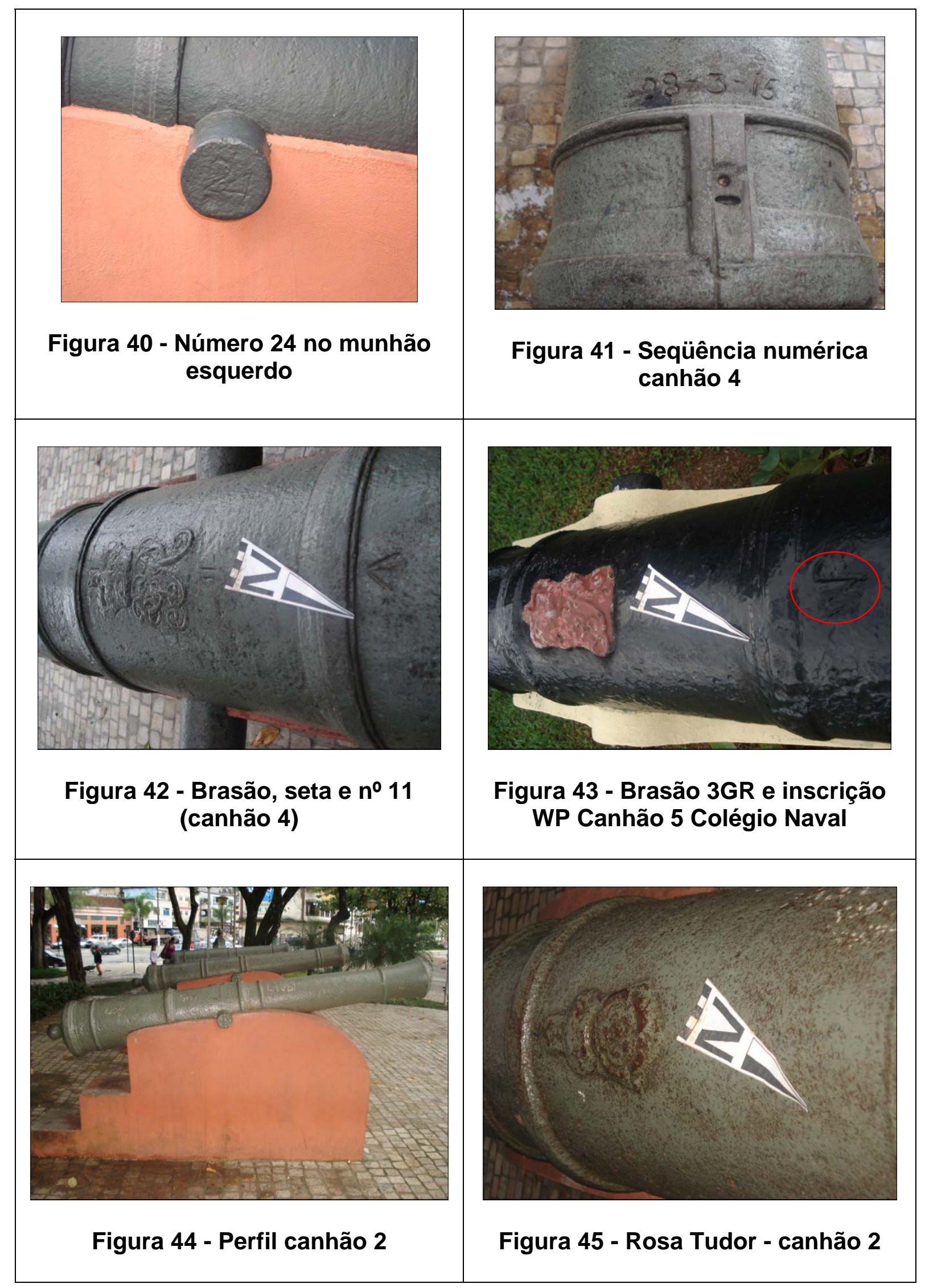


se referir a palavra SOLID. A seqüência numérica da peça está ilegível, o que impossibilita o cálculo da massa do canhão. Importante aqui destacar que no local da seta, ou seja, no primeiro reforço, há uma inscrição batida, WP (figura 43).

Faz-se necessário aqui acrescentar que os canhões Armstrong foram sendo substituídos na Inglaterra pelo padrão Blomefield, a partir de 1792. Nesse sentido, como já dito, muitas peças foram vendidas pelas armadas inglesas ou utilizadas para outros fins. Mas é após 1811, quando Thomas Blomefield condena todos os canhões Armstrong ainda operantes na Inglaterra, que os mesmos são descartados definitivamente (CAMARGO, 2002, p. 57). Isso sugere que essas peças chegaram aqui nas primeiras décadas do século XIX.

Quanto às três peças restantes, serão necessárias pesquisas específicas para mais considerações. Entretanto, mesmo assim descreveremos abaixo algumas de suas características.

\section{Canhão 2 - Praça de Angra dos Reis}

\begin{tabular}{|l|c|}
\hline Padrão & $\begin{array}{c}\text { Não } \\
\text { identificado } \\
\text { Rosa Tudor }\end{array}$ \\
\hline Brasão & B \\
\hline Inscrição Munhão direito & llegível \\
\hline Inscrição Munhão esquerdo & 12 \\
\hline Calibre (lb) & $120 \mathrm{~mm}$ \\
\hline Calibre & $279 \mathrm{~cm}$ \\
\hline Comprimento total da peça & $55,5 \mathrm{~cm}$ \\
\hline Largura & $249 \mathrm{~cm}$ \\
\hline Comprimento funcional & 21 \\
\hline Calibres de comprimento & \\
\hline
\end{tabular}

O canhão 2 da Praça de Angra dos Reis (figura 44) apresenta uma Rosa Tudor como brasão (figura 45). De acordo com CASTRO (comunicação pessoal) este brasão foi utilizado pelas forças Armadas Britânicas da restauração até 1720, quando assumiram os Hanover. É uma peça maior do que as anteriores, o que Ihe dá um valor maior no que diz respeito ao calibres de comprimento. A inscrição B no seu munhão direito pode indicar a Casa de Fundição de Brede, uma das grandes fundições particulares inglesas, capazes de fazer canhões de todos os calibres (figura 46). A seqüência numérica apresenta os números 263 20, o que Ihe dá uma massa equivalente a 1.366,1 kg (figura 47). O canhão 2 não apresenta setas. 


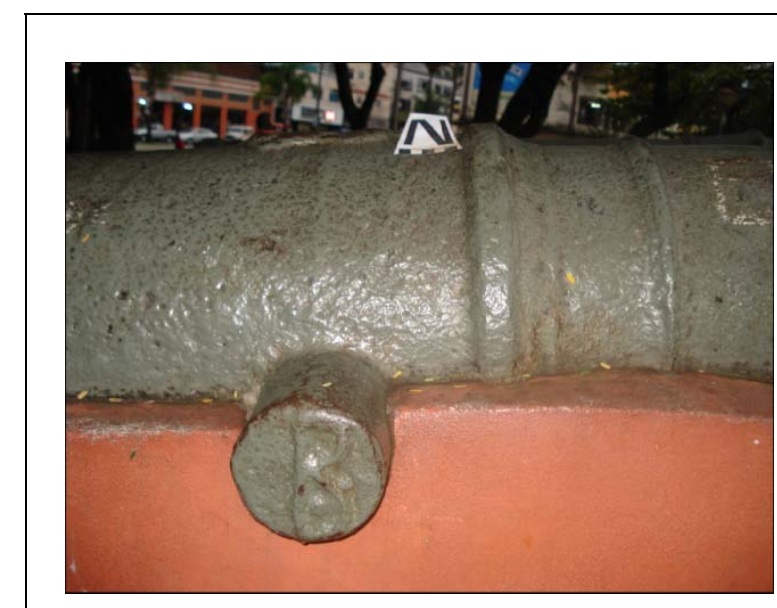

Figura 46 - Munhão direito canhão 2

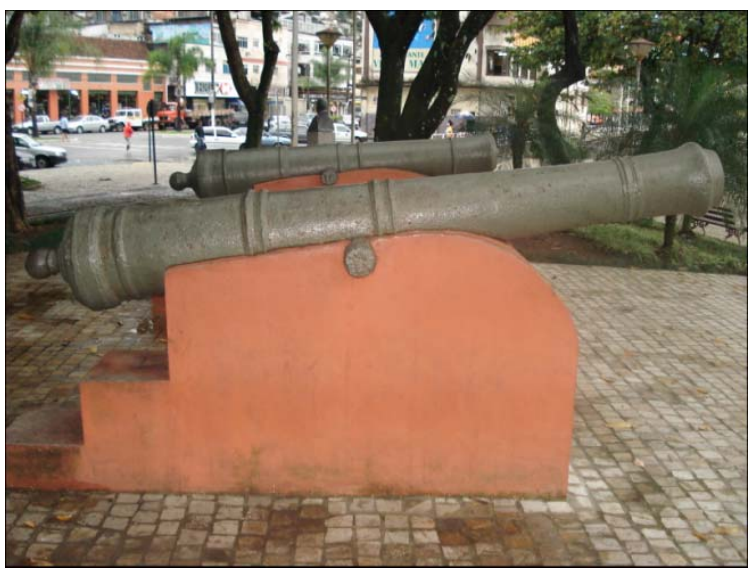

Figura 48 - Perfil canhão 3

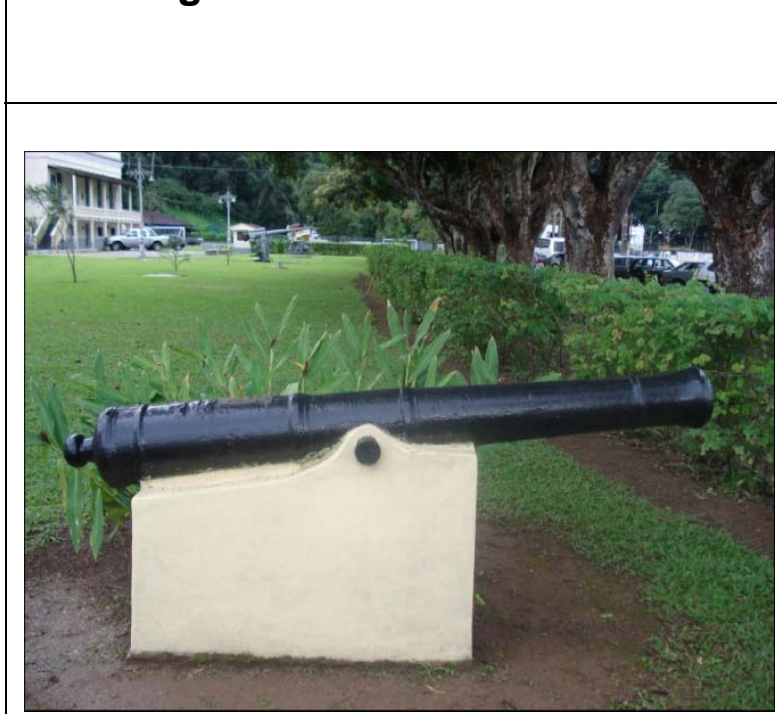

Figura 50 - Perfil canhão 6

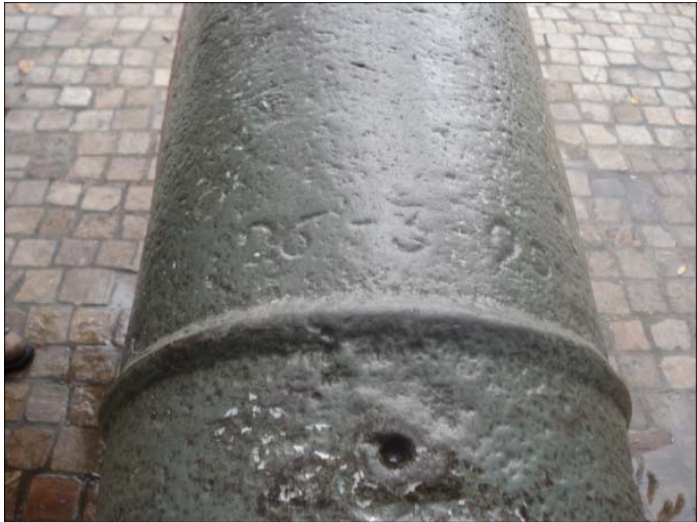

Figura 47 - Inscrição numérica canhão 2

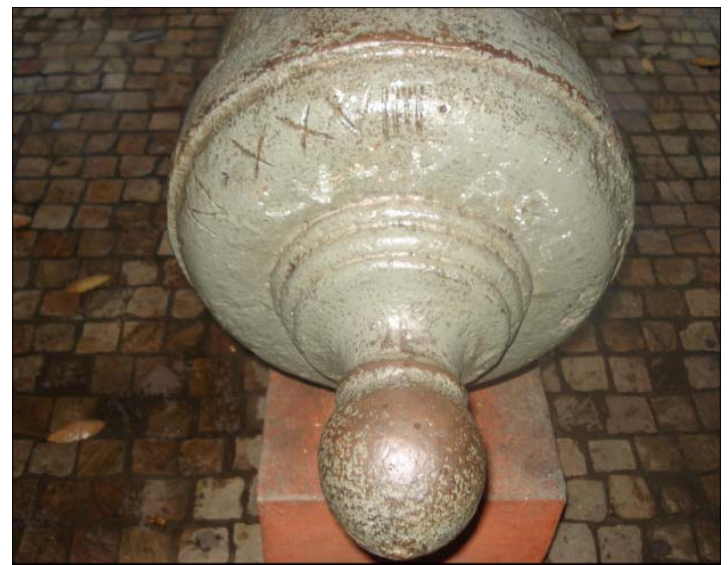

Figura 49 - Inscrição em números romanos canhão 3

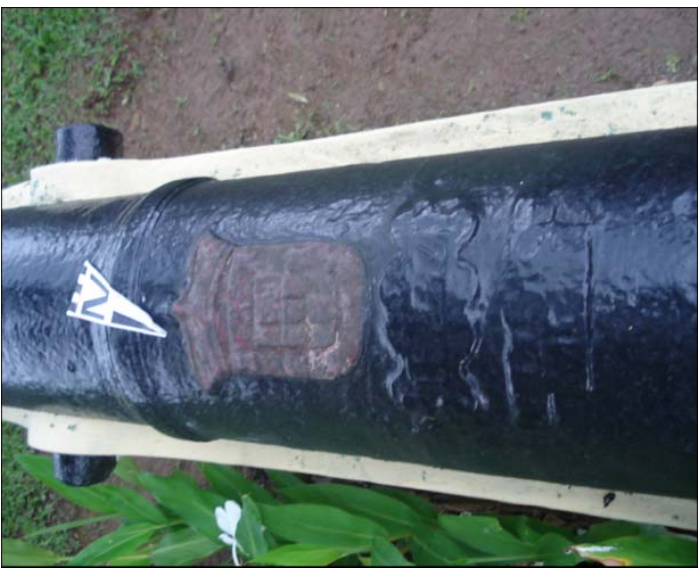

Figura 51 - Brasão canhão 6 Colégio Naval 


\section{Canhão 3 - Praça de Angra dos Reis}

\begin{tabular}{|l|c|}
\hline Padrão & $\begin{array}{c}\text { Não } \\
\text { identificado }\end{array}$ \\
\hline Brasão & Não tem \\
\hline Inscrição Munhão direito & Ilegível \\
\hline Inscrição Munhão esquerdo & Ilegível \\
\hline Calibre (lb) & 12 \\
\hline Calibre & $120 \mathrm{~mm}$ \\
\hline Comprimento total da peça & $293 \mathrm{~cm}$ \\
\hline Largura & $60 \mathrm{~cm}$ \\
\hline Comprimento funcional & $249 \mathrm{~cm}$ \\
\hline Calibres de comprimento & 20.75 \\
\hline
\end{tabular}

O canhão 3 da praça da cidade não apresenta brasão e, de todos os canhões, é o maior. Suas inscrições estão ilegíveis, o que dificulta a sua interpretação. A particularidade desta peça é a inscrição, em números romanos, "N. XXVIIII." (figuras 48 e 49). Segundo CASTRO (comunicação pessoal), estes números podem indicar que a peça é de origem sueca e os mesmos se referem ao peso em unidades escandinavas, com base no pund (libra). Mas devem ser três conjuntos de números (Skepspund, Lispund e pund), equivalentes a quintais, arrobas e libras.

Outro elemento importante nesta peça são as molduras, grandes e numerosas, que podem indicar o padrão Finbanker (tornado famoso pela fundição de Finspong na Dinamarca). Entretanto, como as características são imprecisas é difícil indicar uma data certa de sua fabricação, que deve estar entre os séculos XVII e XVIII.

\section{Canhão 6 - Colégio Naval}

\begin{tabular}{|l|l|}
\hline Padrão & Não identificado \\
\hline Brasão & $\begin{array}{l}\text { Brasão do Império Português } \\
\text { (escudo com 5 quinas sobre } \\
\text { outro escudo com elementos } \\
\text { ilegíveis, encimados por } \\
\text { Coroa. Abaixo há uma com 2 } \\
\text { inscrições ilegíveis em relevo. } \\
\text { O brasão apresenta } \\
\text { coloração avermelhada) }\end{array}$ \\
\hline $\begin{array}{l}\text { Inscrição Munhão } \\
\text { direito }\end{array}$ & Não tem \\
\hline $\begin{array}{l}\text { Inscrição Munhão } \\
\text { esquerdo }\end{array}$ & Ilegível \\
\hline Calibre (lb) & 6 \\
\hline Calibre & 98,8 mm \\
\hline $\begin{array}{l}\text { Comprimento total da } \\
\text { peça }\end{array}$ & $233,5 \mathrm{~cm}$ \\
\hline
\end{tabular}




\begin{tabular}{|l|l|}
\hline Largura & $45 \mathrm{~cm}$ \\
\hline $\begin{array}{l}\text { Comprimento } \\
\text { funcional }\end{array}$ & $215 \mathrm{~cm}$ \\
\hline $\begin{array}{l}\text { Calibres de } \\
\text { comprimento }\end{array}$ & 22 \\
\hline
\end{tabular}

Este canhão apresenta um brasão do Império Português que, segundo CASTRO (com. pessoal) pode ter sido fundido pela Inglaterra, mas sob encomenda de Portugal (figuras 50 e 51). A seqüência numérica está ilegível, o que não permite o cálculo da massa. Sobre o calibre, é o único canhão de calibre 6.

Conforme apresentado anteriormente, sobre as três últimas peças serão necessárias pesquisas mais amplas para mais considerações. No entanto, a questão crucial é que as mesmas são diferentes do padrão Armstrong e, provavelmente, mais antigas.

Para finalizar, não podemos deixar de mencionar estudos de campo realizados em Ponta Grossa e Tapera, na baía de Paraty (OLIVEIRA e FUNARI, 2007). Na região de Ponta Grossa de Paraty foram identificadas estruturas defensivas descritas nos documentos da Câmara da Villa de Paraty (conforme nota de rodapé n. ${ }^{\circ}$ 67) e três canhões, com cerca de $10 \mathrm{~m}$ acima do nível do mar (OLIVEIRA e FUNARI, 2007, p. 26).

Dos três canhões identificados, todos em bom estado de conservação e localizados sobre o solo, verificou-se a existência de dois tipos de peça. O primeiro deles, Blomefield, correspondente às peças 1 e 3. Segundo os autores,

\begin{abstract}
"A peça de número 1 , a sigla do fundidor, WC, é complementada pelas inscrições presentes no munhão esquerdo, onde se observa o número de série, 34846, o fundidor CARRON, da Escócia e o ano de fabricação, 1796 (...). A peça número 3, a sigla indicando o fundidor, GS, que provavelmente corresponda a Geoffrey Swaffam, da Inglaterra".
\end{abstract}

(OLIVEIRA e FUNARI, 2007, p. 27-28)

A outra peça, do padrão Armstrong, apresenta no segundo reforço o brasão de George III. Conforme análise indicada, no primeiro reforço foi identificada a presença de duas setas, correspondentes às marcas do banco de provas inglês, conforme dito anteriormente. No munhão esquerdo, a 
presença da WC corresponde ao fundidor Samuel Walker Company (17461817), de Rotherthan, Inglaterra (OLIVEIRA e FUNARI, 2007, p. 29).

Ainda segundo as pesquisas, na Tapera, além de estruturas defensivas, foram identificados três canhões, embora as fontes documentais apontem a existência de quatro peças de artilharia (OLIVEIRA e FUNARI, 2007, p. 31). Sobre estas peças, de acordo com os autores,

“(...) o suporte do canhão 1 sustenta uma peça de artilharia de modelos Armstrong, com o brasão George III (...). A peça localizada no suporte de número 2 apresentou marca em baixo relevo no primeiro reforço, indicativa para canhões de uso não oficial na Inglaterra (...). O suporte de número 4 também sustenta uma peça de artilharia de modelo Armstrong, com brasão George III (...)".

(OLIVEIRA e FUNARI, 2007, p. 31)

Percebemos assim que a região do litoral sul fluminense, em especial no século XIX, protegeu-se, sobretudo, com peças de artilharia inglesa do século anterior, já consideradas ultrapassadas para a época, pelo seu poder destrutivo, alcance e precisão. Estudos arqueológicos mais detalhados são necessários para a geração de um amplo conhecimento sobre as peças de artilharia existentes em todo esse litoral que abrange a área de Paraty, Angra dos Reis, Itaguaí, Sepetiba, Ilha Grande entre outros. Estes apenas são os primeiros passos. 


\section{CAPÍTULO III}

\section{ARQUEOLOGIA DAS ESTRATÉGIAS DEFENSIVAS NA PONTA LESTE}




\section{Referências documentais sobre as estratégias defensivas na Ponta Leste}

Conforme apresentado anteriormente, percebemos que são abundantes os documentos históricos sobre a defesa da antiga Vila de Angra dos Reis. Mas, e Piraquara e Ponta Leste? Como dito em nota anterior, informações sobre fortificações em Piraquara foram encontradas em cartas de sesmarias e citadas, brevemente, por LIMA (1974) e MENDES (1970). E Ponta Leste? Apenas duas evidências documentais ${ }^{79}$ (registros de terras) foram encontradas sobre essa região que indicam a existência de uma fortificação, em meados do século XIX, que não corresponde ao Forte do Leme, já que o mesmo foi construído a partir de 1908, como demonstram as reportagens mostradas anteriormente. Nos registros de terra a indicação da localidade é Morro da Fortaleza da Ponta Leste, conforme mostrado abaixo,

\begin{tabular}{|c|c|c|c|c|c|c|c|c|c|}
\hline Freguesia & Livro & $\begin{array}{l}\text { Data } \\
\text { Limite }\end{array}$ & Fol. & $\operatorname{Reg}$ & Prop. & Tamanho & Localidade & Limites & Origens \\
\hline $\begin{array}{l}\text { N. S. }{ }^{a} \text { da } \\
\text { Conceição }\end{array}$ & 02 & $\begin{array}{l}1854- \\
1856\end{array}$ & 39 & 39 & $\begin{array}{l}\text { João de } \\
\text { Aguiar e } \\
\text { sua } \\
\text { mulher } \\
\text { Maria } \\
\text { da } \\
\text { Conceiç } \\
\text { ão }\end{array}$ & $\begin{array}{l}37 \text { e meia } \\
\text { braças } \\
\text { com } \\
\text { logradouro } \\
\text { na frente }\end{array}$ & $\begin{array}{l}\text { Morro da } \\
\text { Fortaleza } \\
\text { da Ponta } \\
\text { Leste }\end{array}$ & $\begin{array}{l}\text { Um lado } \\
\text { Ângelo } \\
\text { Alves, } \\
\text { outro lado } \\
\text { Angélica } \\
\text { Maria }\end{array}$ & $\begin{array}{l}\text { Herança } \\
\text { de seu } \\
\text { finado } \\
\text { pay } \\
\text { Jozé } \\
\text { Aguiar }\end{array}$ \\
\hline
\end{tabular}

\begin{tabular}{|c|c|c|c|c|c|c|c|c|c|}
\hline Freguesia & Livro & $\begin{array}{l}\text { Data } \\
\text { Limite }\end{array}$ & Fol. & Reg & Prop. & Tamanho & Localidade & Limites & Origens \\
\hline $\begin{array}{l}\text { N. S. }{ }^{a} \text { da } \\
\text { Conceição }\end{array}$ & 02 & $\begin{array}{l}1854- \\
1856\end{array}$ & 223 & 223 & $\begin{array}{l}\text { João } \\
\text { Ignácio } \\
\text { Pontes }\end{array}$ & $\begin{array}{l}\text { Umas } \\
\text { braças }\end{array}$ & $\begin{array}{l}\text { Morro da } \\
\text { Fortaleza } \\
\text { da Ponta } \\
\text { Leste }\end{array}$ & $\begin{array}{l}\text { De um } \\
\text { lado } \\
\text { Joanna } \\
\text { Maria, de } \\
\text { outro } \\
\text { Jezuino } \\
\text { Francisco } \\
\text { Esteves e } \\
\text { fundos }\end{array}$ & $\begin{array}{l}\text { Nada } \\
\text { consta }\end{array}$ \\
\hline
\end{tabular}

${ }^{79}$ Esses registros de terras encontram-se no Arquivo do Estado do Rio de Janeiro, porém o acesso a estes se deve à produção de um Banco de Dados pela arqueóloga Nanci Vieira de Oliveira sobre a região. Este banco de dados possui informações sobre fontes documentais, fontes bibliográficas, patrimônio histórico, sítios arqueológicos entre outros. 


\begin{tabular}{|l|l|l|l|l|l|l|l|l|l|}
\hline & & & & & & & & $\begin{array}{l}\text { que tiver } \\
\text { por direito }\end{array}$ & \\
\hline
\end{tabular}

Antes dos registros de terras temos uma informação dada por John Mawe, em 1808, quando este viajante inglês usa as seguintes palavras para descrever a Ilha Grande,

“(...) a terra é em geral, muito alta e irregular; bem arborizada no interior (...). As suas costas estão apenas parcialmente habitadas. 0 estreito que a separa do continente, excelente porto em toda a sua extensão, era ponto de encontro de alguns corsários ingleses, durante nossa guerra contra a Espanha (grifo meu)".

(MAWE, 1944, p. 101)

De acordo com o mapa (figura 52) podemos propor que o estreito a que John Mawe se referia é a Ponta Leste, sendo essa a região mais próxima entre a Ilha Grande e o continente, o que exigiria a aplicabilidade de um sistema de defesa militar, pois era um dos pontos mais profundos da Baía da Ilha Grande, que permitia a entrada de grandes embarcações. Além disso, uma única referência historiográfica é dada por LIMA (1974, p. 233) quando este afirma existir fortificações em Piraquara, Tucupê e Ponta Leste, todas consideradas enseadas propícias ao desembarque de navios estrangeiros. Dessa forma, como as referências em documentos históricos, sobre a defesa dessas enseadas são poucas, executamos as etapas de campo, cujo resultado será apresentado a seguir. 


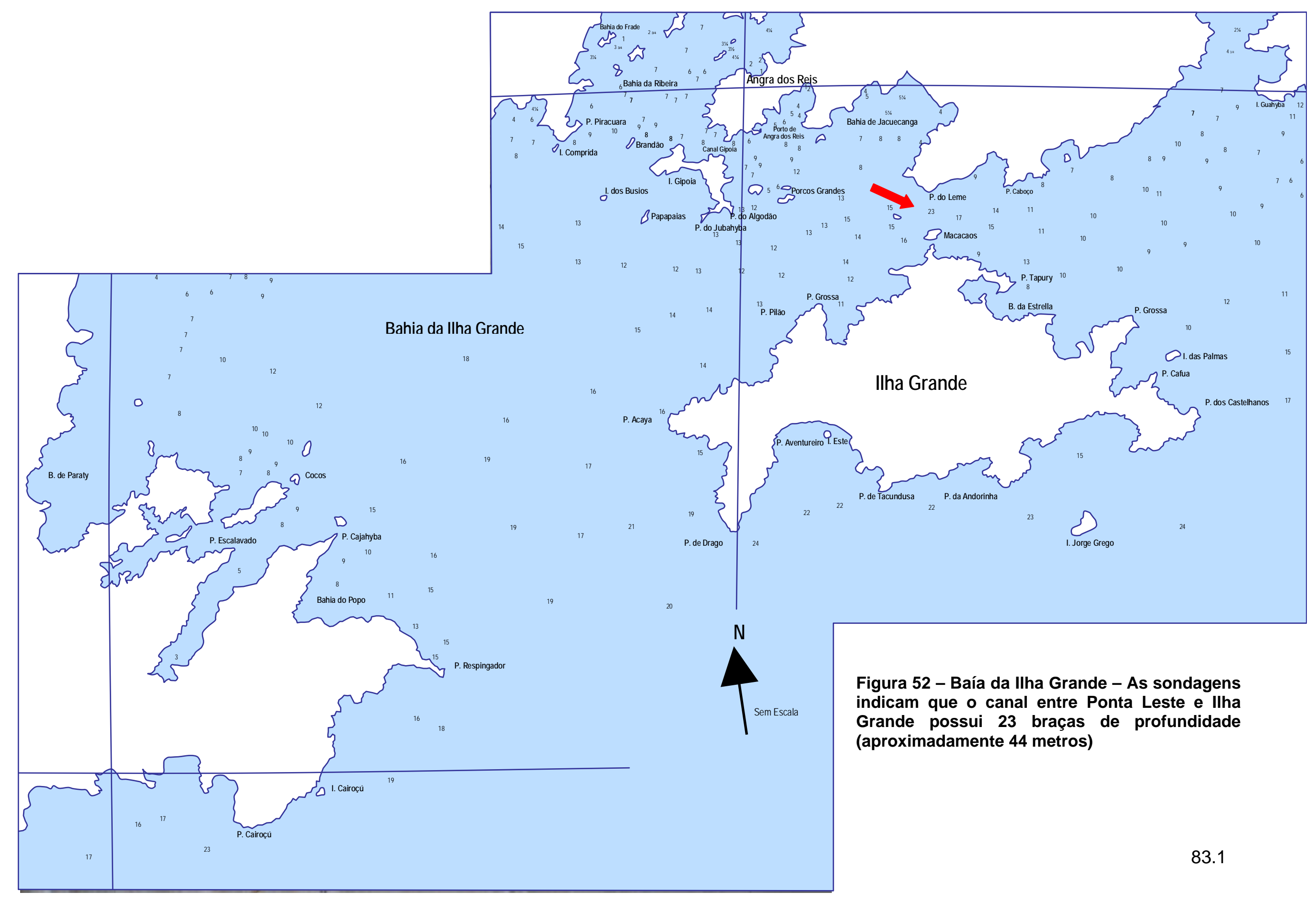




\section{As etapas de campo em Ponta Leste}

Antes de iniciarmos este item é importante reforçar o esclarecimento quanto à denominação Ponta Leste. Historicamente, a área onde se encontra o Forte do Leme é conhecida como Ponta Leste (ver figuras 1 e 2). No entanto, a carta do IBGE (1974) apresenta subdivisões para a Ponta Leste: Ponta do Leste, Ponta do Pasto (onde está localizado o píer da Petrobrás) e Ponta do Leme, onde foi construído o Forte do Leme (figura 3). Interessa aqui destacar que a denominação Ponta do Leme já aparece no século XIX, nos relatórios da Marinha, o que talvez tenha influenciado o nome da construção: Forte do Leme. Mas como os habitantes locais não utilizam essa denominação (conforme figura 4) preferimos manter a que resistiu ao tempo: Ponta Leste.

Nesse sentido, a área onde se concentrou esta pesquisa fica a aproximadamente $20 \mathrm{~km}$ da cidade de Angra dos Reis ${ }^{80}$. A partir da análise dos documentos e mapas históricos, que indicam que a Ponta Leste situa-se no canal mais profundo entre o continente e a llha Grande, e da existência do Forte do Leme, determinamos a área que foi objeto de um levantamento sistemático de superfície.

Como a região é muito extensa, utilizamos como referência o Forte do Leme e fizemos a inspeção visual na área desta construção (figura 53). No total foram executadas três etapas de campo.

Quanto à primeira etapa de campo, fizemos o reconhecimento da área onde se encontra o Forte do Leme e tiramos as medidas de suas estruturas (quartel, banheiro, área descoberta, galerias subterrâneas, fosso dos canhões, Casa do Comandante), cujas descrições mostramos a seguir.

\footnotetext{
${ }^{80}$ Da entrada da cidade de Angra dos Reis até o trevo da Petrobrás, que dá acesso a Ponta Leste são 11 km A partir daí, para alcançar a área do Forte do Leme são, aproximadamente, 8 quilômetros.
} 


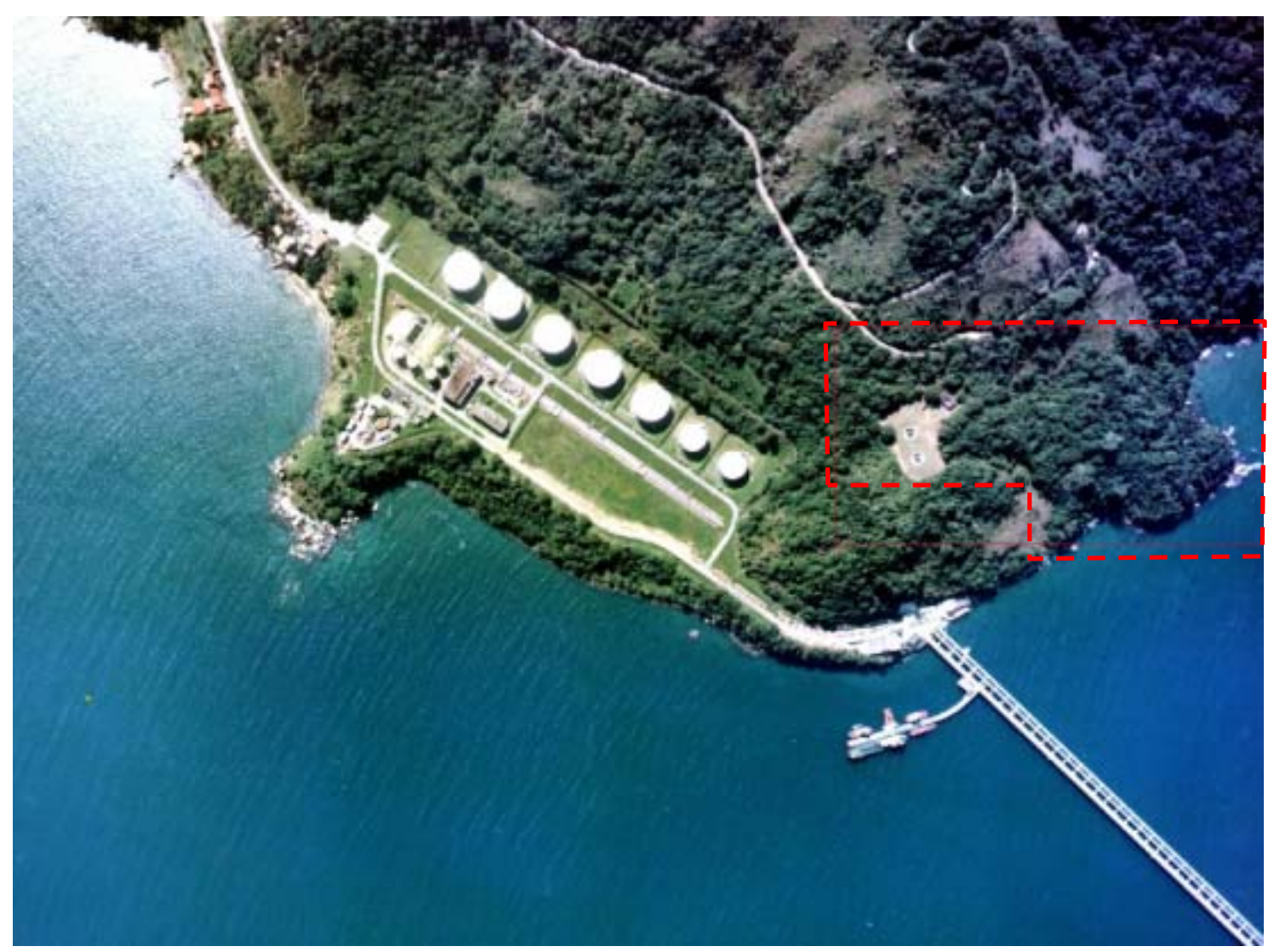

Figura 53 - Ponta Leste - Área de inspeção visual 


\section{O Forte do Leme}

Como dissemos no início deste trabalho, o Forte do Leme foi construído na primeira década do século XX e teve sua inauguração no ano de 1911. Sua construção esteve ligada ao objetivo de transformar a região da Ilha Grande em um porto militar. Para tanto, além do Forte do Leme, foi construída a Escola de Grumetes na cidade de Angra dos Reis. Ainda fazia parte deste plano a construção do Arsenal da Marinha, projeto não finalizado.

Entretanto, mesmo que este Forte tenha sido construído fora do contexto de defesa contra o contrabando de ouro e o tráfico de escravos, intensamente praticado na região, não deixamos de descrever essa construção. Cabe dizer que a Ponta Leste tem grande valor estratégico, já que foi utilizada para as baterias defensivas, contemporâneas a Piraquara, e também para o Forte do Leme no século $X X$.

Essa estrutura defensiva é composta por quartel, banheiro, uma área cercada e descoberta, paiol e dois fossos circulares (bateria), onde se encontram os canhões (figuras 54a e 54b). Importante aqui destacar que o acesso ao paiol e às peças de artilharia é feito através de galerias subterrâneas. A 150 m desta construção há outra estrutura identificada como a Casa do Comandante (Relatório do Forte do Leme, Ministério do Exército, 1994, p. 1-2). Todas essas construções foram feitas com as técnicas de alvenaria.

\section{Quartel}

A planta baixa do quartel (figura 55) indica que este edifício tem 12 cômodos, distribuídos em uma área de, aproximadamente, $275 \mathrm{~m}^{2}$. É difícil precisar a função de cada cômodo, pois, as plantas originais desta construção não foram encontradas. No entanto, descreveremos algumas de suas características.

A sua fachada é composta por janelas em arco (figura 57) e o prédio ainda possui as paredes laterais e a treliça de ferro onde eram assentadas as telhas. No entanto, não há uma telha, devido ao seu estado de abandono (figura 58). O mesmo ocorre com a tubulação que, provavelmente, era de 


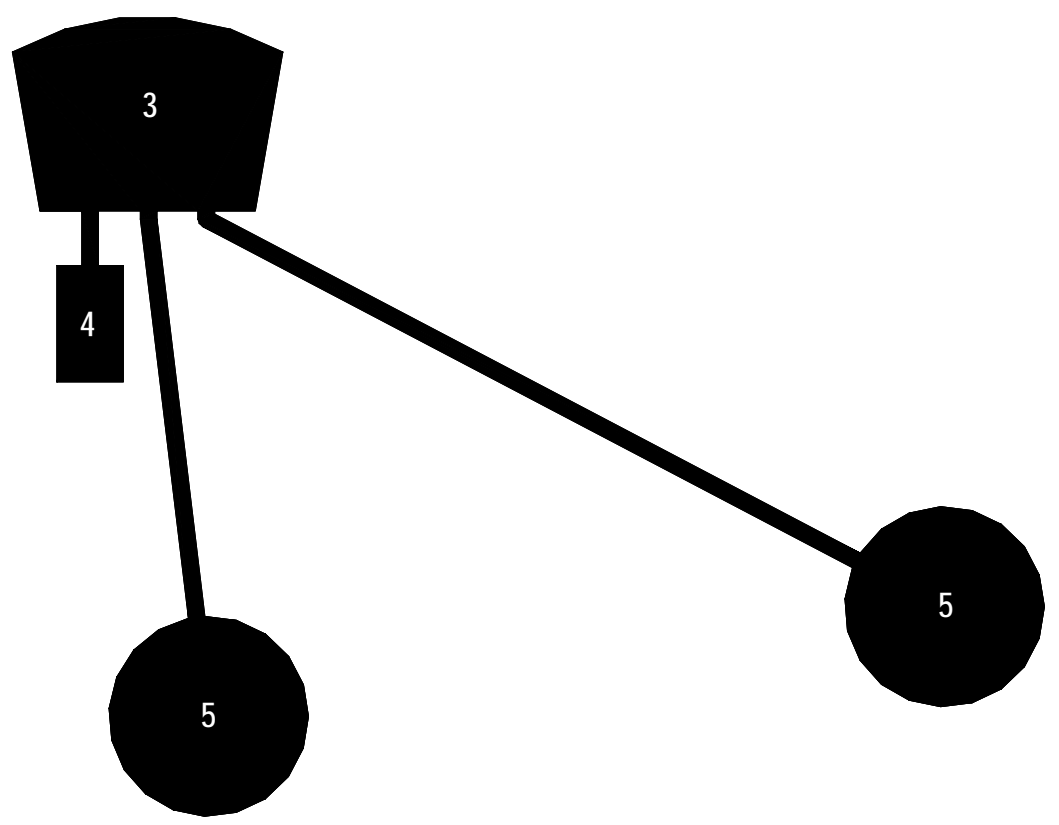

Figura 54a - Esquema de situação das edificações do Forte do Leme. 1. Quartel; 2. Banheiro; 3. Retaguarda (entrada do paiol [4] e do fosso dos canhões [5]); 6. Casa do Comandante (deslocada, no esquema) 


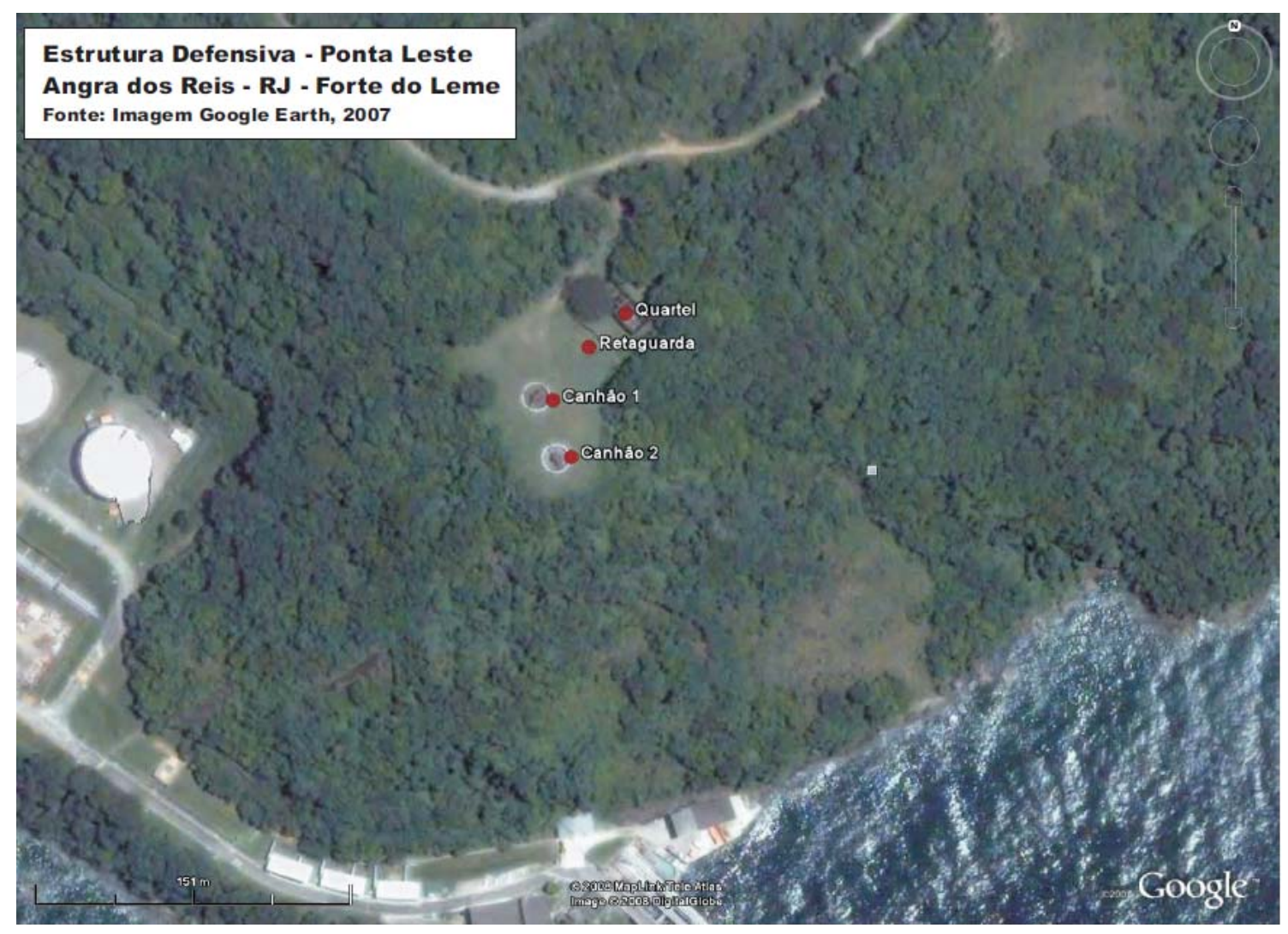

Figura 54b - Imagem de satélite Forte do Leme 


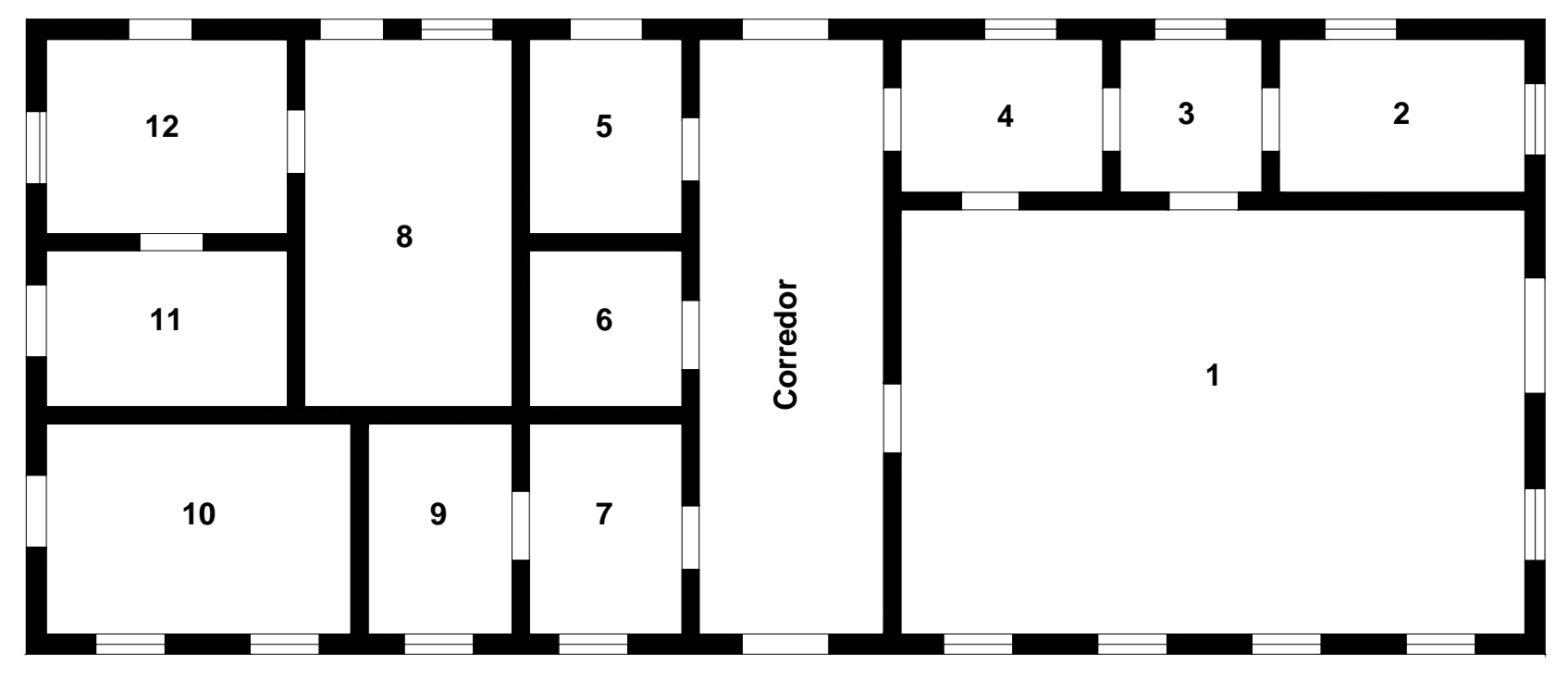

Figura 55 - Planta baixa do quartel do Forte do Leme
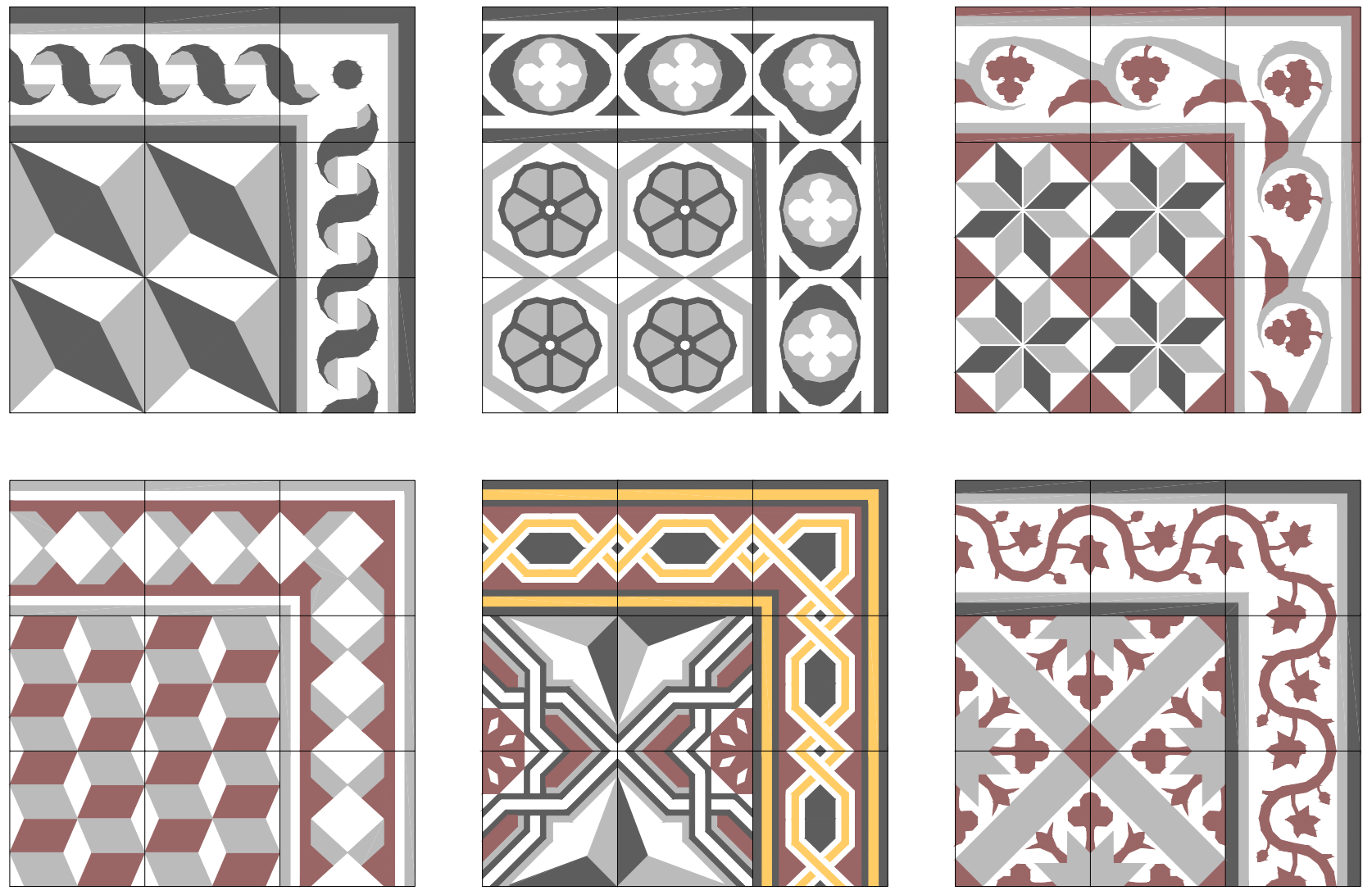

Figura 56 - Alguns pisos identificados no Forte do Leme 


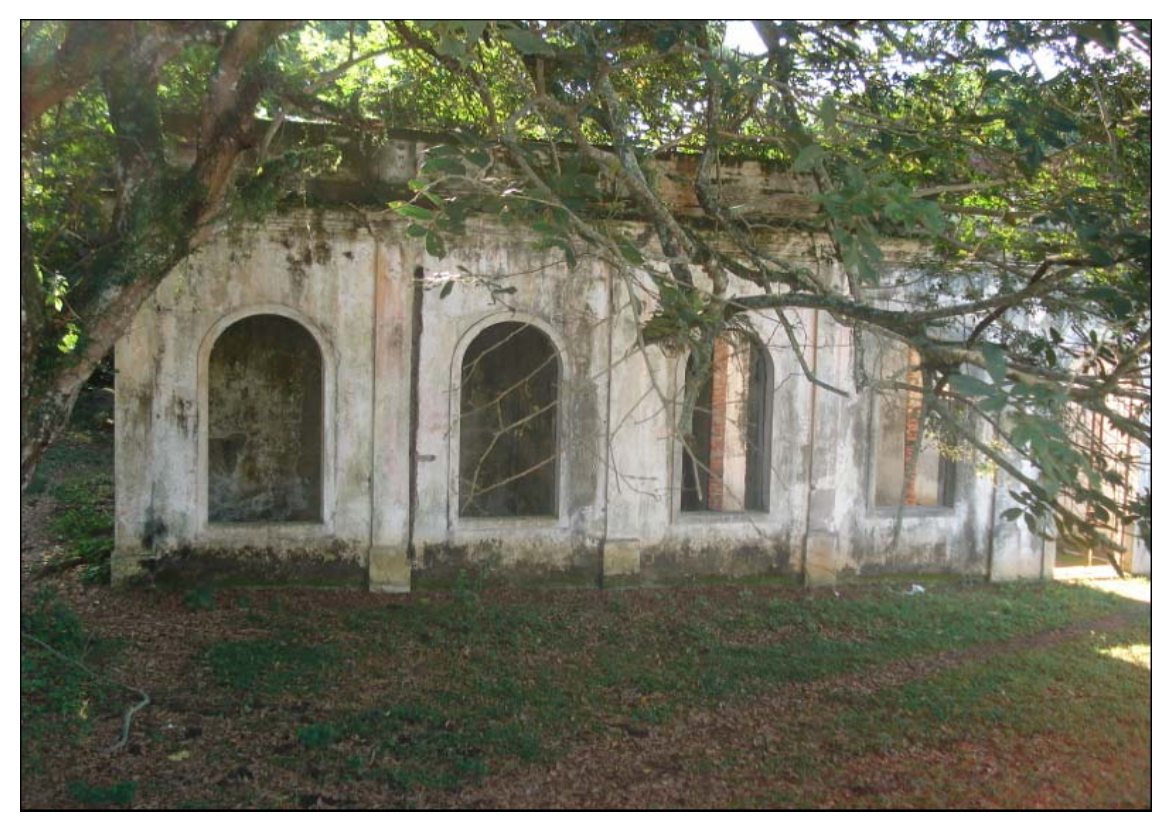

Figura 57 - Detalhe da fachada do quartel do Forte do Leme

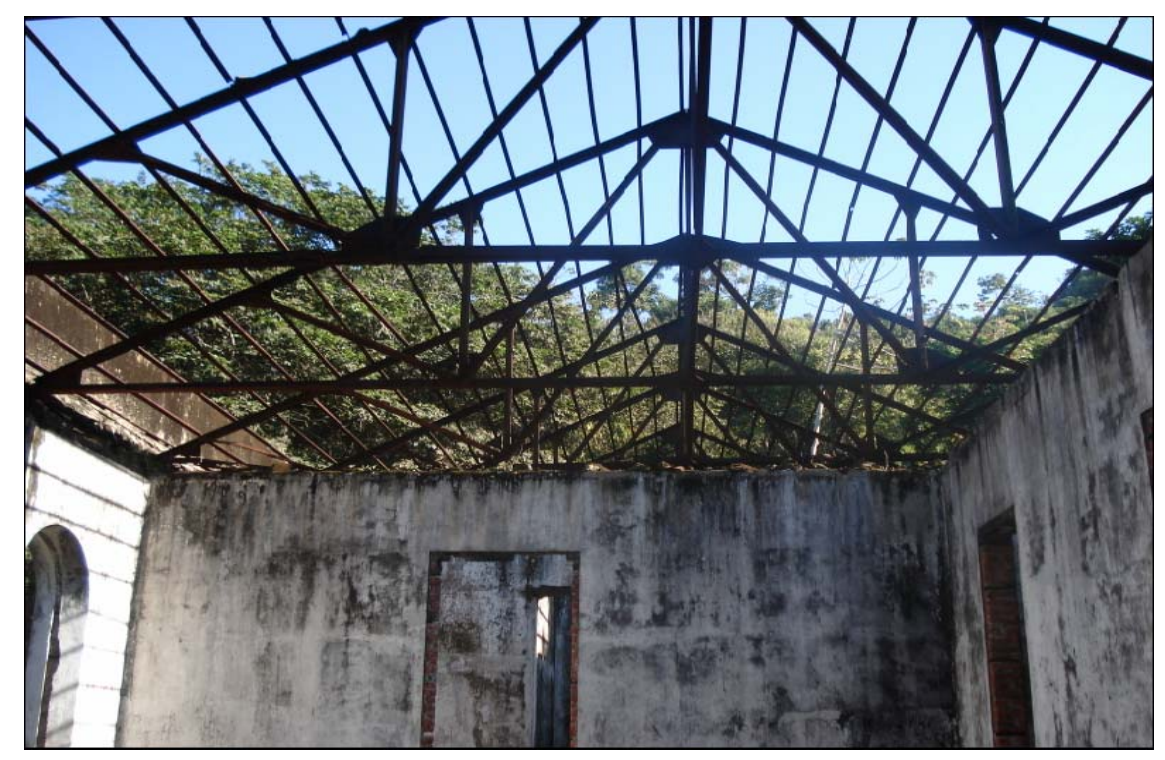

Figura 58 - Treliça de ferro do quartel 
cobre, conforme nos indicam os vestígios de oxidação peculiar desse material e as informações dos moradores da região.

O cômodo n. ${ }^{\circ} 1$, identificado na planta, além de ser o maior, apresenta uma porta (à da direita) bem larga, que foge do esquema geral das entradas e passagens do edifício. Acima dessa porta larga, há um resquício da entrada original (um arco), e os tijolos entre a parte alta dessa entrada mais recente, e o arco (provavelmente mais antigo) têm coloração diferente de todos outros tijolos expostos no edifício (figura 59). Ainda há nesta porta uma rampa.

O cômodo n. ${ }^{\circ} 5$ é o único, dentro deste edifício, que apresenta vestígios de uma grade, logo à sua entrada e uma latrina, o que pode indicar que era um local reservado à prisão. Vale ainda destacar que neste cômodo há vestígios de pedras nas paredes (figura 60).

Quanto à soleira, é a mesma em todo o edifício (figura 61), porém, situação igual não acontece com os pisos, conhecidos como ladrilhos hidráulicos ${ }^{81}$, que são variados, conforme descrevemos abaixo.

Os cômodos n. ${ }^{\circ}$ (s) 3, 4 e 7 apresentam piso nos tons branco e cinza, com motivos geométricos; o cômodo $\mathrm{n}^{0}$. 1 apresenta piso em tons branco e cinza, claro e escuro, com motivos florais. $\mathrm{O}$ cômodo n. ${ }^{\circ} 2$ apresenta piso em tons cinza, claro e escuro, branco e vermelho, com motivos florais, o n. ${ }^{0} 5$ apresenta piso de cores vermelha, branca e cinza, na forma geométrica. $O$ corredor possui o piso em tons cinza, branco, vermelho e amarelo, com estrela

${ }^{81}$ Os ladrilhos hidráulicos são bem resistentes e possuem a medida geral de $20 \times 20 \mathrm{~cm}$. Esse tipo de piso chegou primeiro a São Paulo na primeira década do século $X X$, com os imigrantes italianos, num momento de grande expansão imobiliária na cidade. $O$ material passou a ser amplamente utilizado nas áreas "frias" das residências, quando deixava de ser utilizado o cimentado "vermelhão", tido como material muito pobre. Cabe ainda destacar que em casas modestas esse tipo de piso era utilizado, mas, ou era liso ou com algumas peças com desenho simples com uma ou duas cores, normalmente geométrico, formando "tapetes". Nas construções mais abastadas, o desenho era mais sofisticado, com formas mais elaboradas e com mais cores, como é o caso do Forte do Leme. Uma das peculiaridades do ladrilho hidráulico é a possibilidade de ser assentado com juntas insignificantes, uma vez que, por serem fabricados com base e superfície de argamassas de cimento, os pisos de ladrilhos hidráulicos (ao contrário do que acontece com os pisos cerâmicos) acompanham as deformações da estruturas de concreto armado devidas às alterações climáticas, sobretudo quanto à temperatura. A denominação ladrilho hidráulico refere-se à técnica de fabricação deste tipo de piso: após o molde, as peças são deixadas em repouso por 12 horas e depois são mergulhadas na água (ao contrário de materiais cerâmicos que são queimados) e deixadas para secar durante 10 a 15 dias. Informações disponíveis nos endereços eletrônicos: http//www.azullimão.com.br e http//vivaocentro.org.br, acesso em 10/10/2007. 


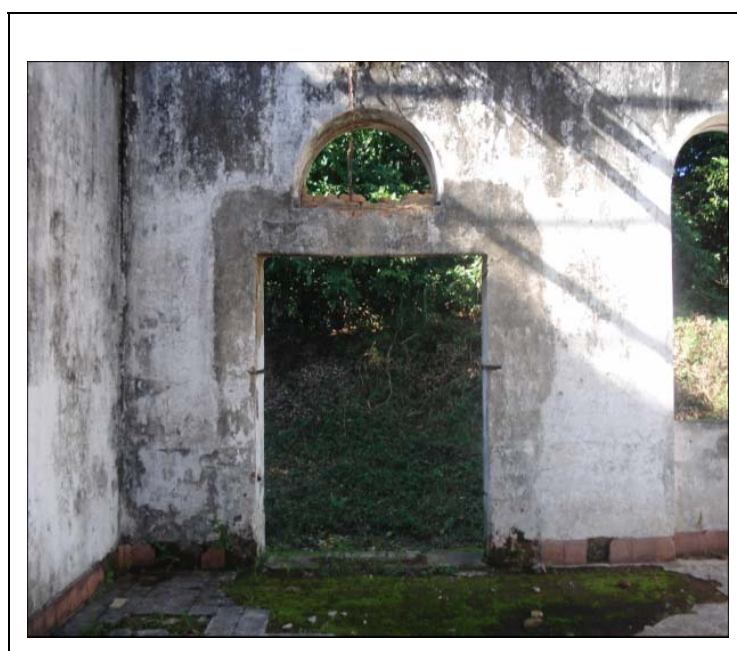

Figura 59 - Porta larga e arco (à direita) do cômodo n. ${ }^{\circ} 1$

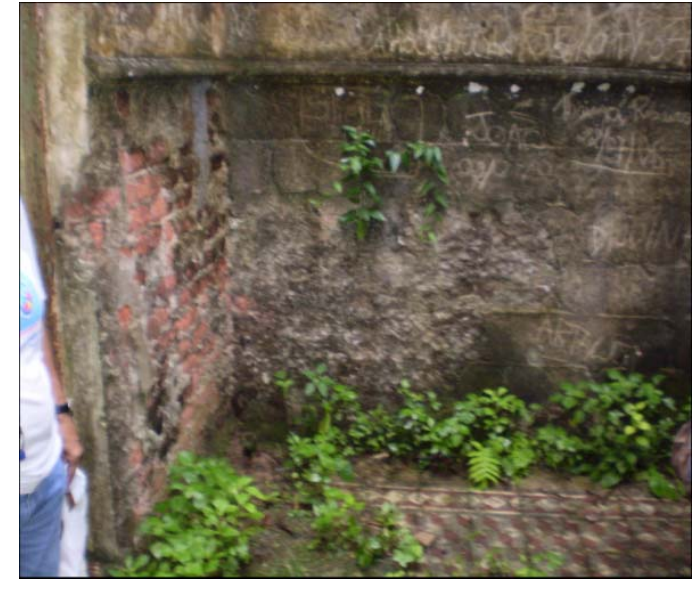

Figura 60 - Parede (tijolo e pedra), cômodo n. $^{\circ} 5$

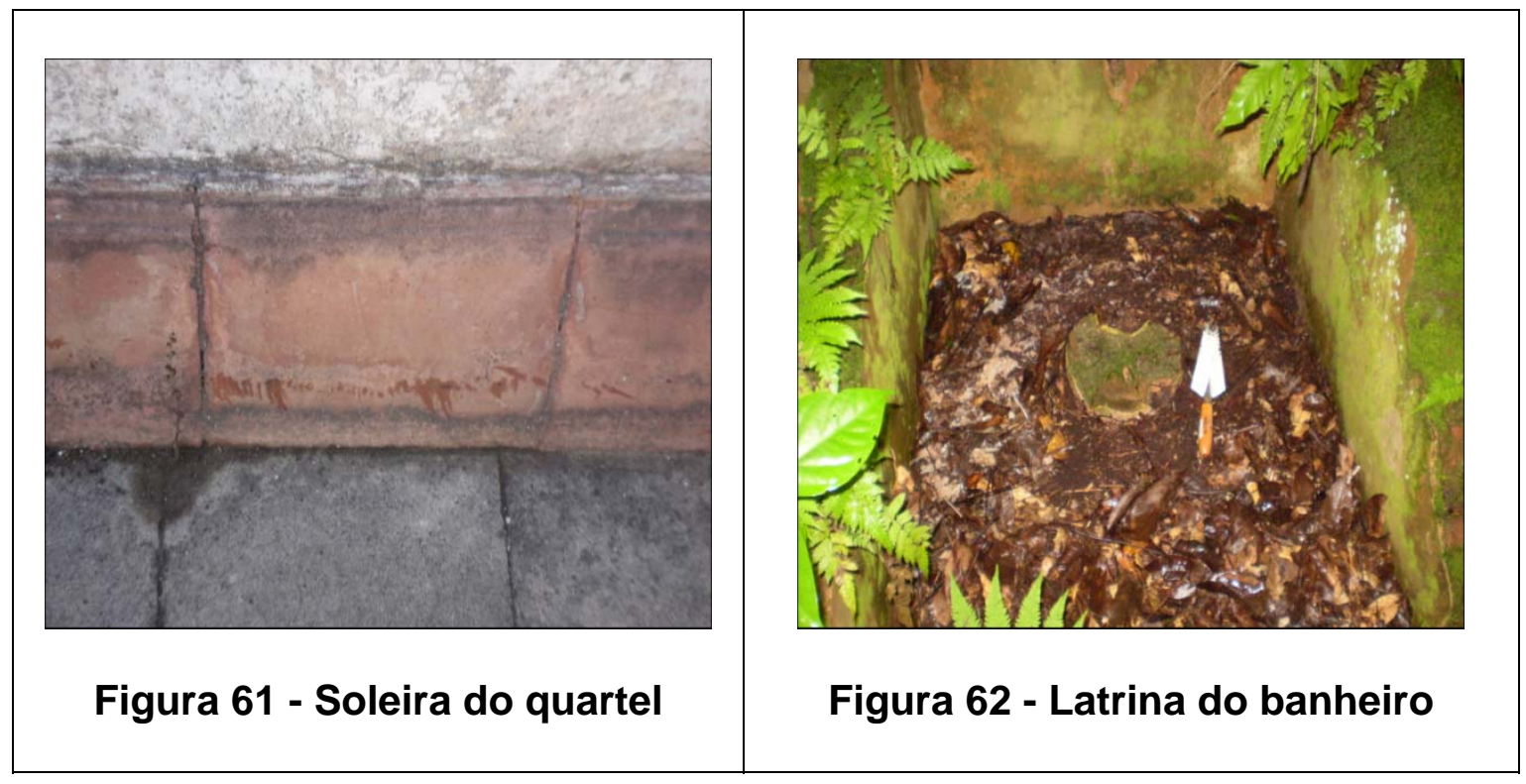


em dois tons de cinza. O cômodo $\mathrm{n}^{0}$. 6 apresenta piso nas cores branca, vermelha e cinza, com motivos florais (ver figura 56). O cômodo n. ${ }^{\circ} 8$ apresenta piso em tons branco e cinza e os n. ${ }^{\circ}$ (s) 11 e 12 apresentam piso em tons branco e cinza, com motivo em relevo, na forma de cruz estilizada. E, por fim, os cômodos n. ${ }^{\circ}$ (s) 09 e 10 não têm piso.

\section{Banheiro}

O banheiro do Forte do Leme está localizado a 13,70 m do quartel e tem uma área de, aproximadamente, $21 \mathrm{~m}^{2}$. O mesmo apresenta na sua fachada uma porta central (em arco) e duas laterais (figura 63). A primeira delas dá acesso a seis compartimentos, onde se encontram as latrinas (figura 62). Estes compartimentos são separados por paredes e portas, no entanto, somente os dois últimos ainda possuem suas entradas totalmente conservadas. Além disso, em cada um dos cômodos com latrinas, na parte superior, há orifícios, destinados à ventilação. As duas portas laterais dão acesso a compartimentos, provavelmente, referentes ao banho. O banheiro apresenta pisos, mas, por causa do estado de abandono e do acúmulo de lixo, estes não puderam ser identificados.

\section{Área cercada}

À retaguarda do quartel, a 12,34 m, existe uma área cercada, porém descoberta, que dá acesso ao paiol e às galerias subterrâneas, que levam aos canhões. Essa área tem um espaço livre de aproximadamente, $170 \mathrm{~m}^{2}$ (figura 64). O seu muro externo apresenta $18 \mathrm{~m}$ de extensão, com seis seteiras, ao longo dessa construção (figura 65).

Para o acesso ao paiol há um corredor de 3,27 m. Esse cômodo possui, aproximadamente, $27 \mathrm{~m}^{2}$ (figuras 66 e 67). Em seu interior há marcas na parede que indicam que havia prateleiras.

Quanto às galerias que dão acesso aos canhões, estas possuem extensões diferentes: a primeira delas tem $24,65 \mathrm{~m}$ e a segunda $43,30 \mathrm{~m}$ (figura 68). No final desses túneis subterrâneos há dois fossos circulares, com 

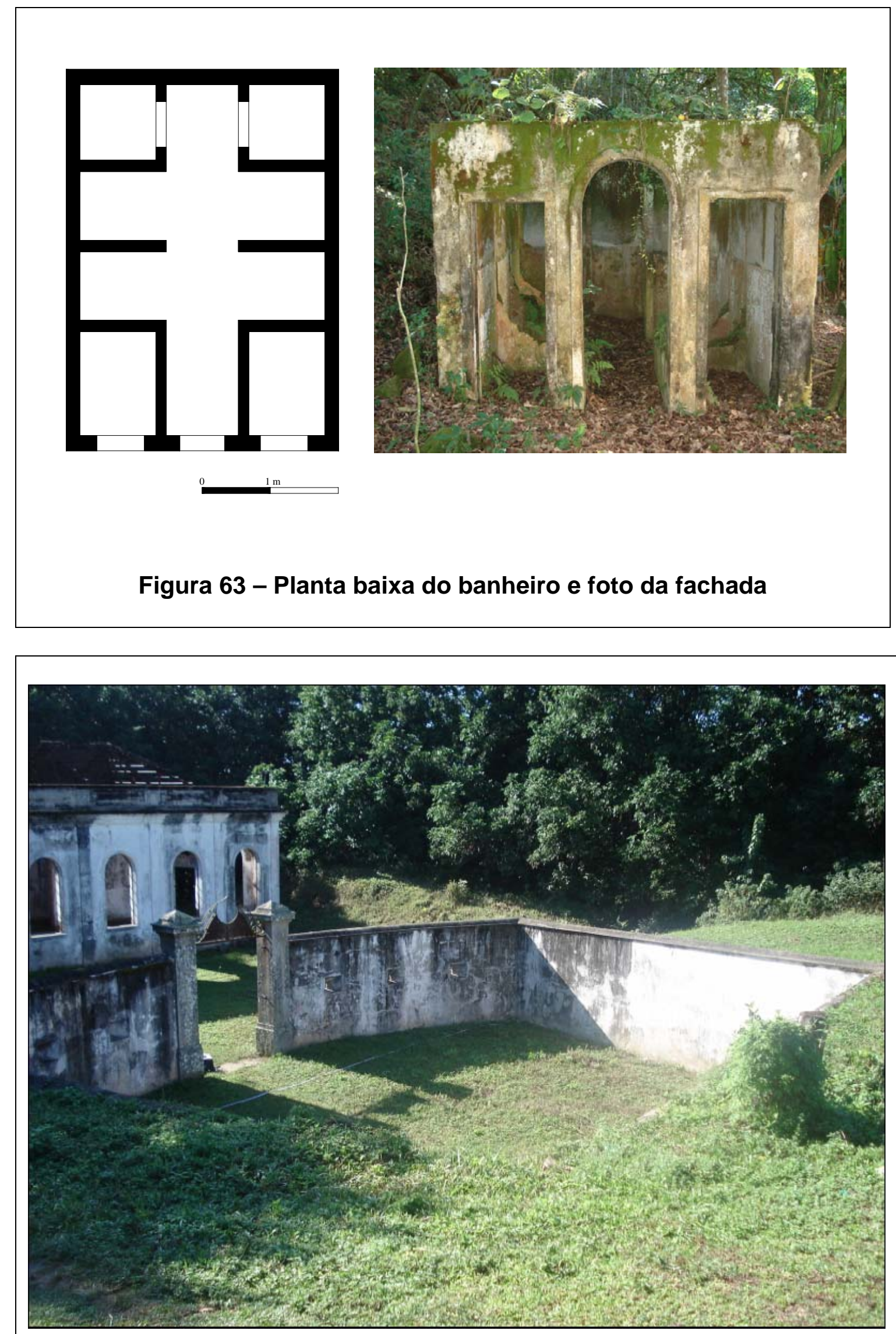

Figura 64 - Área cercada à retaguarda do Forte do Leme 

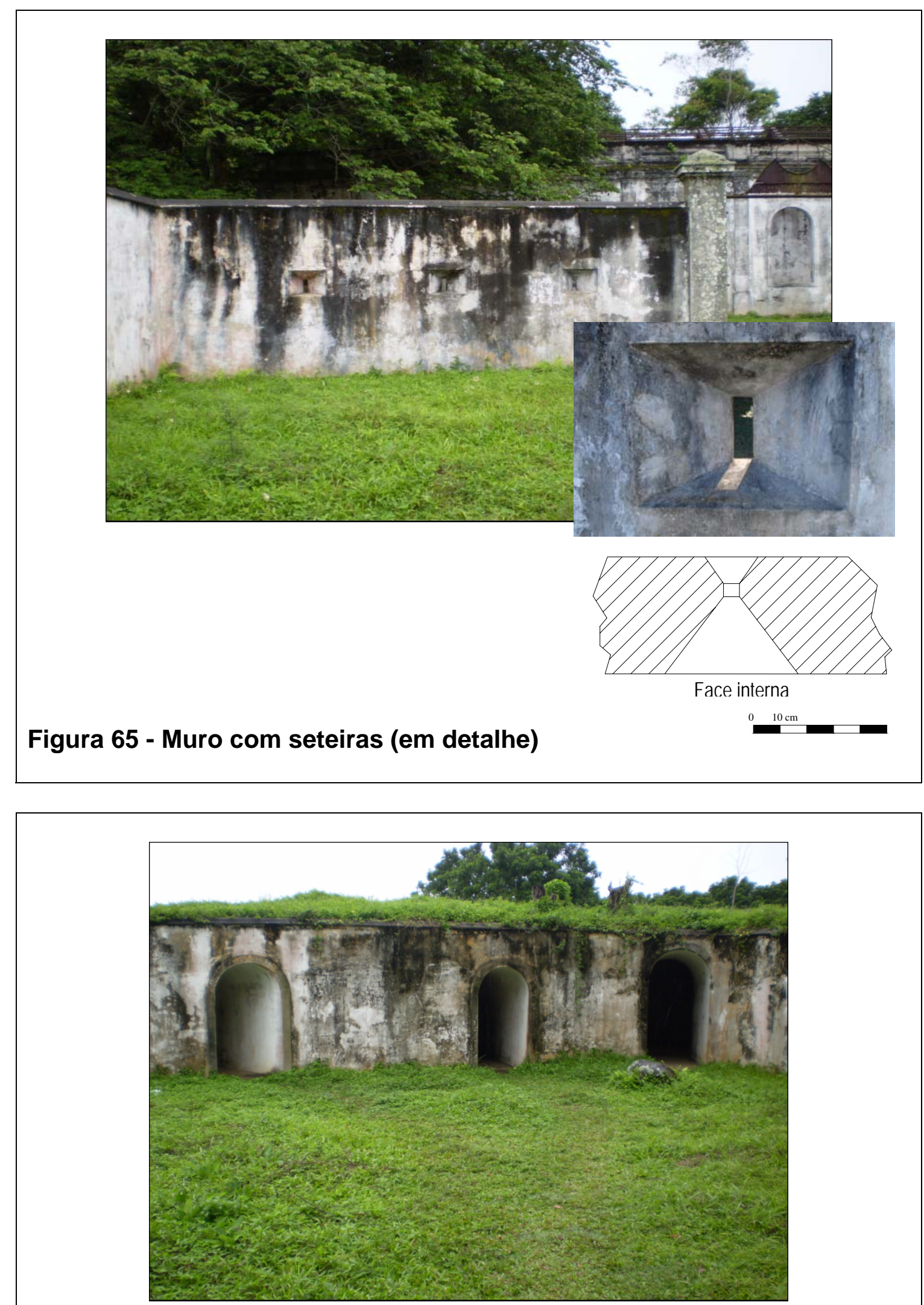

Figura 66 - Acesso ao paiol (à direita) e às duas galerias do Forte do Leme 


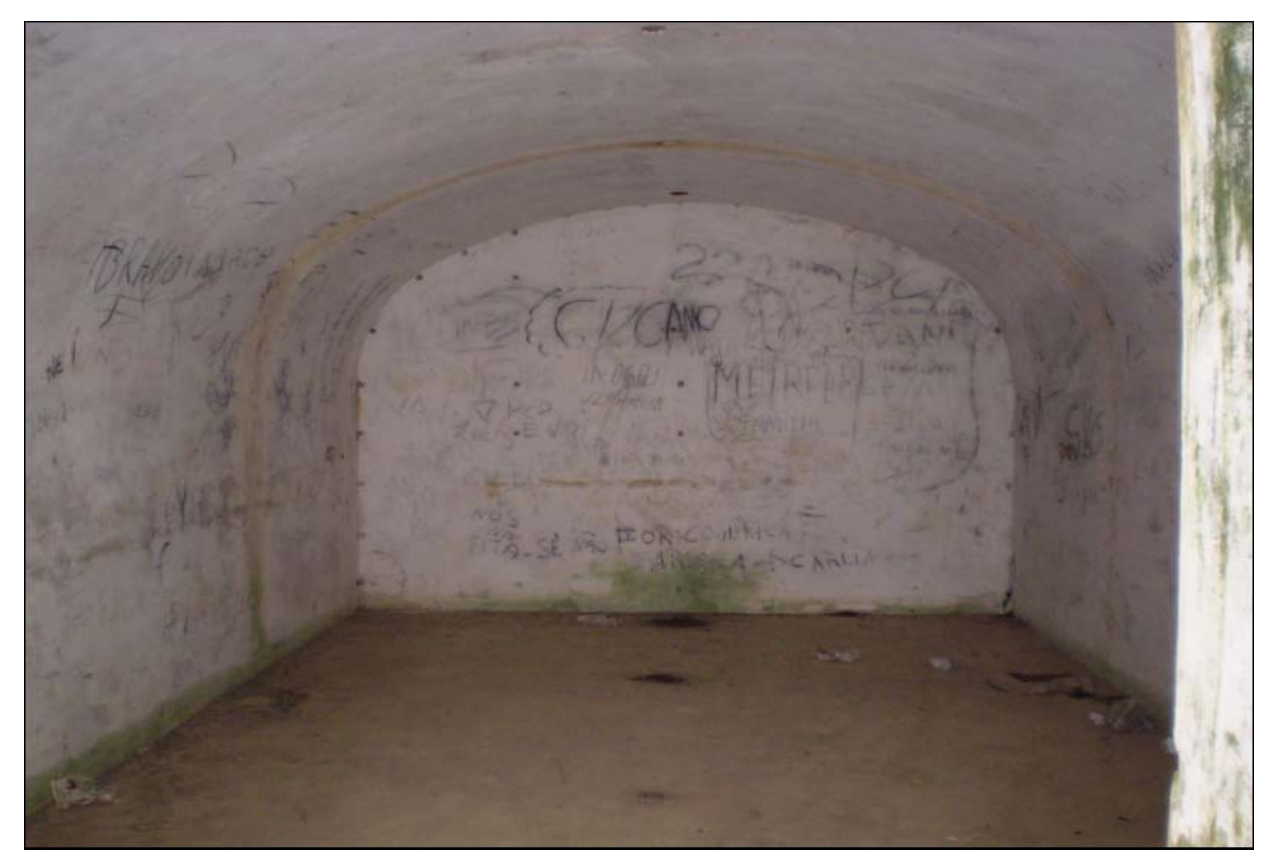

Figura 67 - Paiol do Forte do Leme

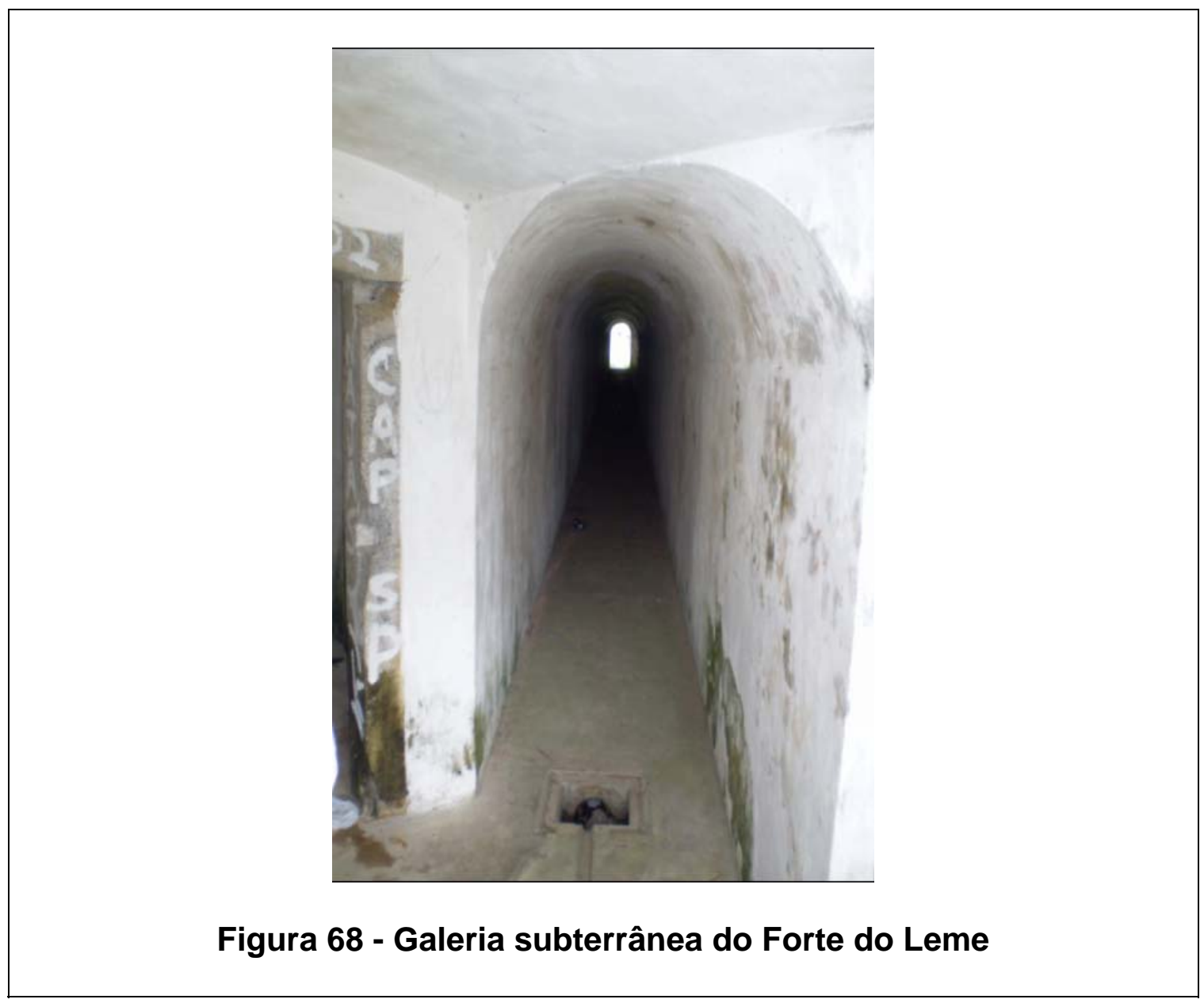


diâmetro de 12,55 m e altura aproximada de 2,80 m (figura 69). Neste local encontram-se as peças de artilharia.

\section{Canhões}

Os dois canhões do Forte do Leme foram fabricados na Inglaterra, na empresa Armstrong \& Witworth, no ano de 1901. Essas peças de aço possuem o calibre de $234 \mathrm{~mm}$, e uma massa equivalente a $28.110 \mathrm{Kg}$. Esse tipo de peça, de alma raiada, era usada no Brasil, a partir de meados do século XIX, para dar ao projétil um movimento de rotação em torno do seu eixo logitudinal, aumentando o alcance e a precisão das armas, além de permitir o uso de projéteis alongados, com cargas explosivas maiores do que as antigas granadas esféricas. Dessa forma, os projéteis poderiam atingir alvos a 6-8 quilômetros de distância (Manual de preenchimento..., p. 32).

Essas peças ainda possuem reparo hidropneumático ${ }^{82}$ de pião central (figura 70), um tipo de reparo de artilharia onde o berço da peça gira sobre um eixo central preso ao solo, ou seja, o recuo da peça é eliminado, no todo ou parcialmente, pela ação de mecanismos hidráulicos e de mola existentes no berço, fazendo com que só o tubo recue durante o disparo (Manual de preenchimento..., p. 55).

BARRETO (1958, p. 218) afirma que estes canhões são navais, pertencentes ao antigo encouraçado Riachuelo ${ }^{83}$, um dos mais modernos navios da Marinha Imperial Brasileira, que foi desativado em 1910, um ano antes da inauguração do Forte do Leme. Entretanto, apesar de sua potência e grande poder destrutivo, provavelmente os únicos disparos feitos por estas peças, enquanto estavam no Forte do Leme, foi no dia de sua inauguração,

\footnotetext{
${ }^{82}$ Reparo pode ser definido como, "carreta, conjunto de peças em que pousa o canhão ou que o transporta ao campo de batalha" (Manual de preenchimento..., p. 53). Nesse sentido, há vários tipos de reparo: reparo a Onofre, reparo de crinolina, reparo de falcas, reparo de marinha, reparo de pião central, caso do Forte do Leme.

${ }^{83}$ Podemos citar como informações adicionais, "o encouraçado Riachuelo foi construído na Inglaterra pelo estaleiro Samuda \& Brothers, tendo tido sua quilha batida 31 de agosto de 1881, sendo lançado ao mar em 07 de junho de 1883 e incorporado à armada imperial brasileira em 19 de novembro de 1883. Seu primeiro comandante foi o capitão de mar e guerra Eduardo Wanderkolk, mais tarde o primeiro ministro da Marinha. Logo que chegou ao Brasil o navio foi subordinado à Esquadra de Evoluções, sob o comando do Almirante Barão de Jaceguay entre os anos de 1884 e 1885", consultado no site: http://www.revistanaval.kit.net/riachuelo.htm, acesso em 20/08/2007.
} 

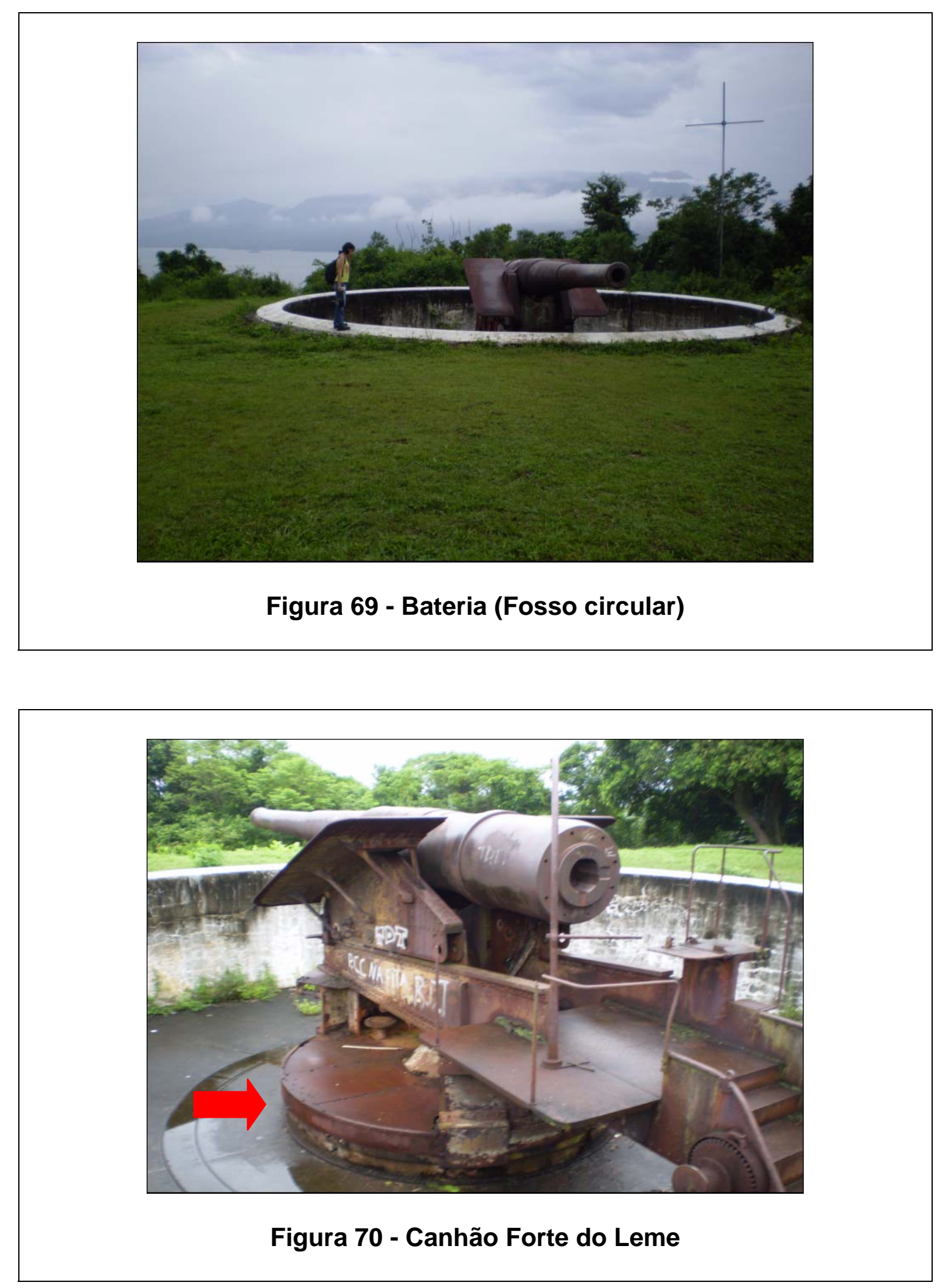
com o presidente Hermes da Fonseca, conforme documento histórico citado na Introdução (vide p. 3).

\section{Casa do Comandante}

A Casa do Comandante está, aproximadamente, a 150 m das construções anteriores e sua área é de $105 \mathrm{~m}^{2}$. Em seu interior há muita vegetação e material desmoronado, o que dificulta a descrição. Esta estrutura apresenta uma varanda, voltada para o mar, com uma escada de três degraus. Grandes janelas circundam todo o edifício (figuras 71 e 72).

Ainda sobre o Forte do Leme, BARRETO (1598, p. 218), o descreve como uma construção defensiva de pouca duração. A data provável de sua desativação é 1950, tendo sido seu último comandante o Sargento Zoroastro Serrão Maia (MENDES, 1970, p. 395). Vale destacar que na etapa de levantamento documental desta pesquisa, identificamos no Arquivo Histórico do Exército a documentação sobre este Sargento. Entretanto, sobre o período em que permaneceu sob o comando do Forte do Leme nada foi encontrado.

Para finalizar, ainda nesta primeira etapa, com a ajuda de moradores locais, identificamos duas estruturas de pedra seca e duas estruturas de pedra cortadas, como veremos a seguir. Antes, porém, vejamos algumas interpretações sobre a distribuição espacial das construções que compõem o Forte do Leme. 


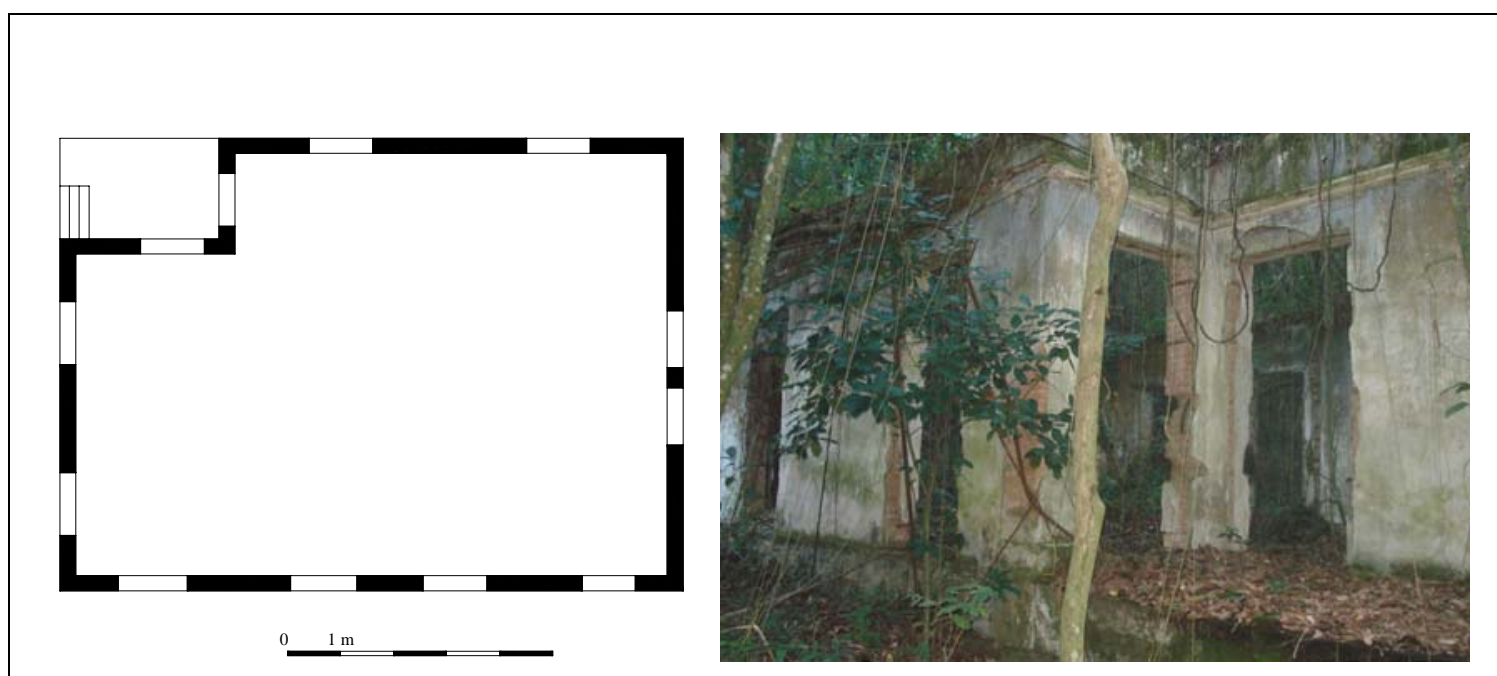

Figura 71 - Planta baixa Casa do Comandante e foto da face noroeste

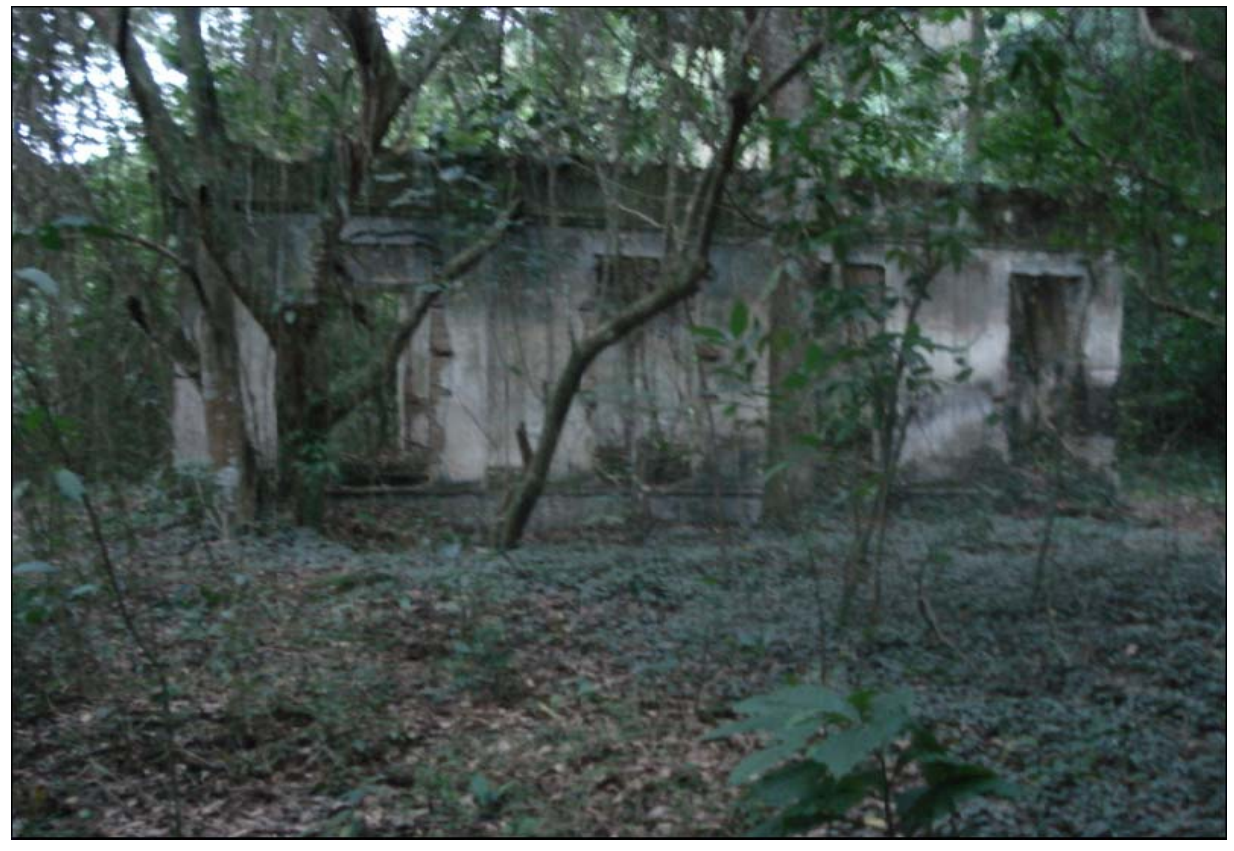

Figura 72 - Casa do Comandante - face sul 


\section{Reflexões sobre a distribuição espacial do Forte do Leme}

Como proposto no início desta pesquisa, a paisagem na qual foi implantado o Forte do Leme merece ser analisada. Esse forte, construído a, aproximadamente, $82 \mathrm{~m}$ de altitude num morro que foi terraplanado, em frente à Ilha Grande a ao mar, possui relação entre suas estruturas. Assim, apresentamos algumas reflexões sobre a distribuição dessas construções que compõem essa fortificação. Entretanto, faz-se necessário destacar que esta é apenas uma leitura espacial, entre as tantas possíveis.

Começamos a pensar na distribuição das estruturas, a partir de seu acesso. Então, o primeiro questionamento foi o seguinte: como se dava o acesso ao Forte do Leme? Como nenhuma planta ou outro tipo de documento que pudesse indicar a resposta foi encontrado, tecemos algumas considerações a respeito.

Em primeiro lugar, o acesso ao Forte do Leme se dá por uma estrada que parte dela é asfaltada (figura 73). Mesmo assim, esse acesso é difícil. Provavelmente, essa estrada asfaltada não existia na primeira década do século XX e o acesso poderia ser feito pelas fazendas vizinhas ao Forte, a norte. Entretanto, um documento escrito, mais precisamente, uma reportagem de jornal, traz uma informação interessante sobre a construção dessa fortificação: os materiais construtivos do Forte do Leme chegaram a Angra dos Reis através de dois rebocadores (vide pág. 5).

Essa informação é importante porque pode indicar que para a locomoção deste material foi necessário utilizar as enseadas que compõem a Ponta Leste, como acesso ao local de construção (figura 74). Pensando desta forma, uma das enseadas que dá entrada ao Forte do Leme localiza-se na Ponta do Pasto, a oeste, onde foi construído o Píer da Petrobrás. Desta enseada até um local próximo do Forte do Leme foi construída uma escada, composta por mais de 80 degraus, o que indica a declividade do terreno (em linha reta a distância da Ponta do Pasto ao Forte do Leme é de quase $800 \mathrm{~m}$, conforme figuras 75 e 76). Como na época da construção essa escada não existia, a Ponta do Pasto poderia ser um local inviável para o acesso ao Forte do Leme. 


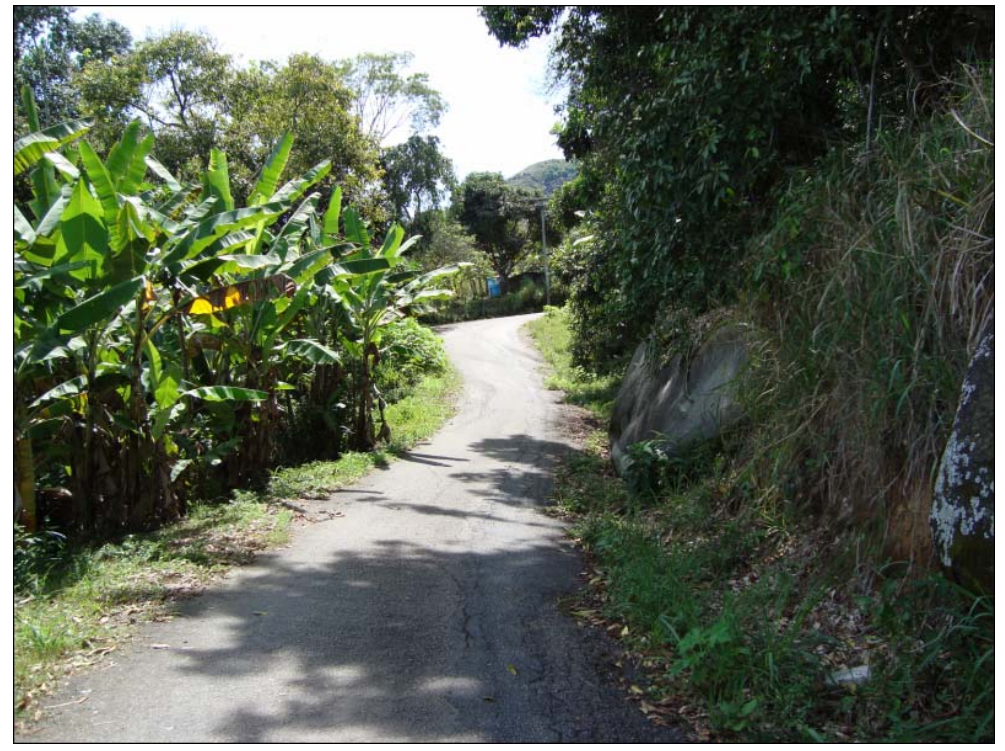

Figura 73 - Estrada de acesso ao Forte do Leme

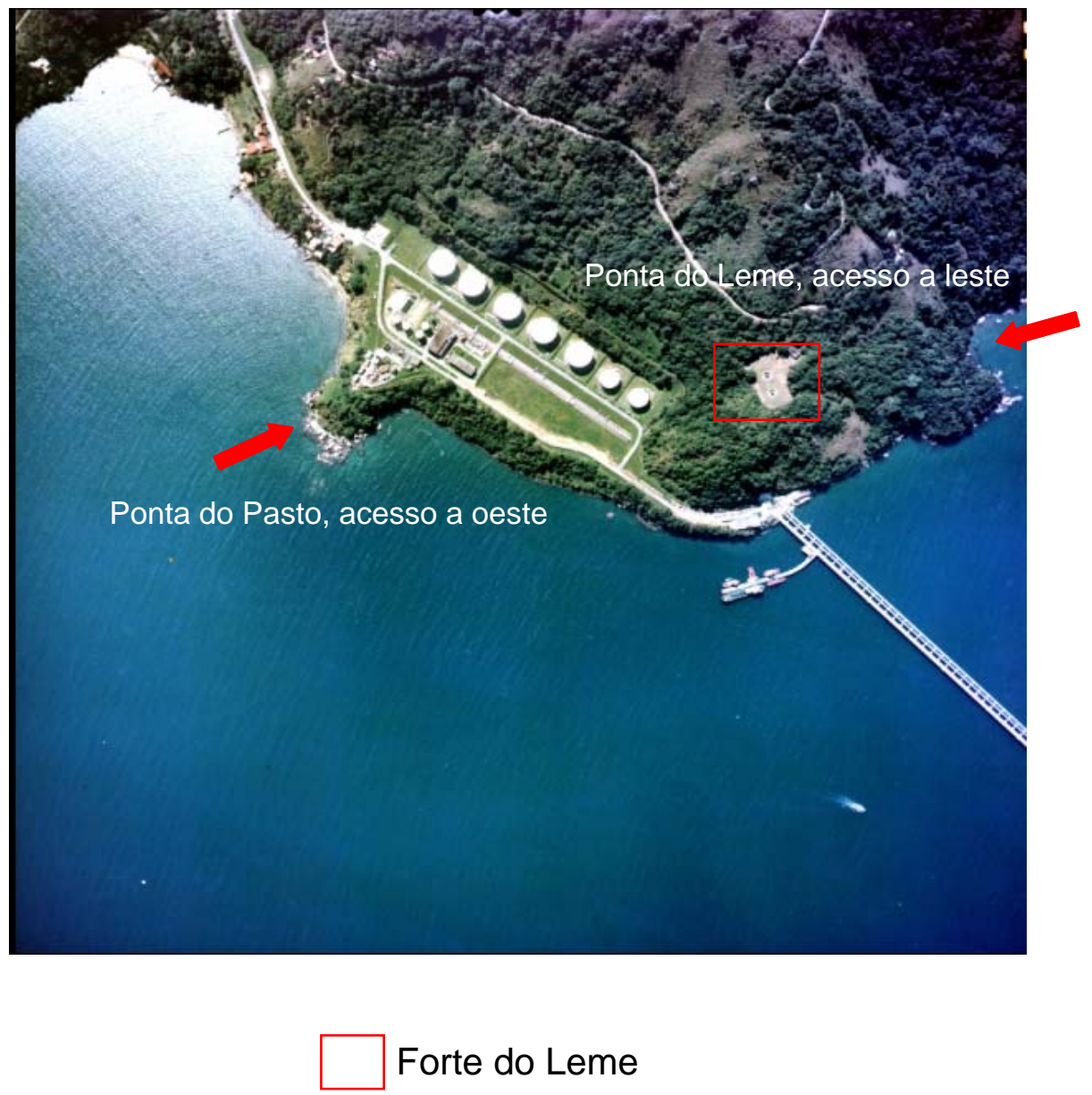

Figura 74 - Enseadas de acesso ao Forte do Leme 


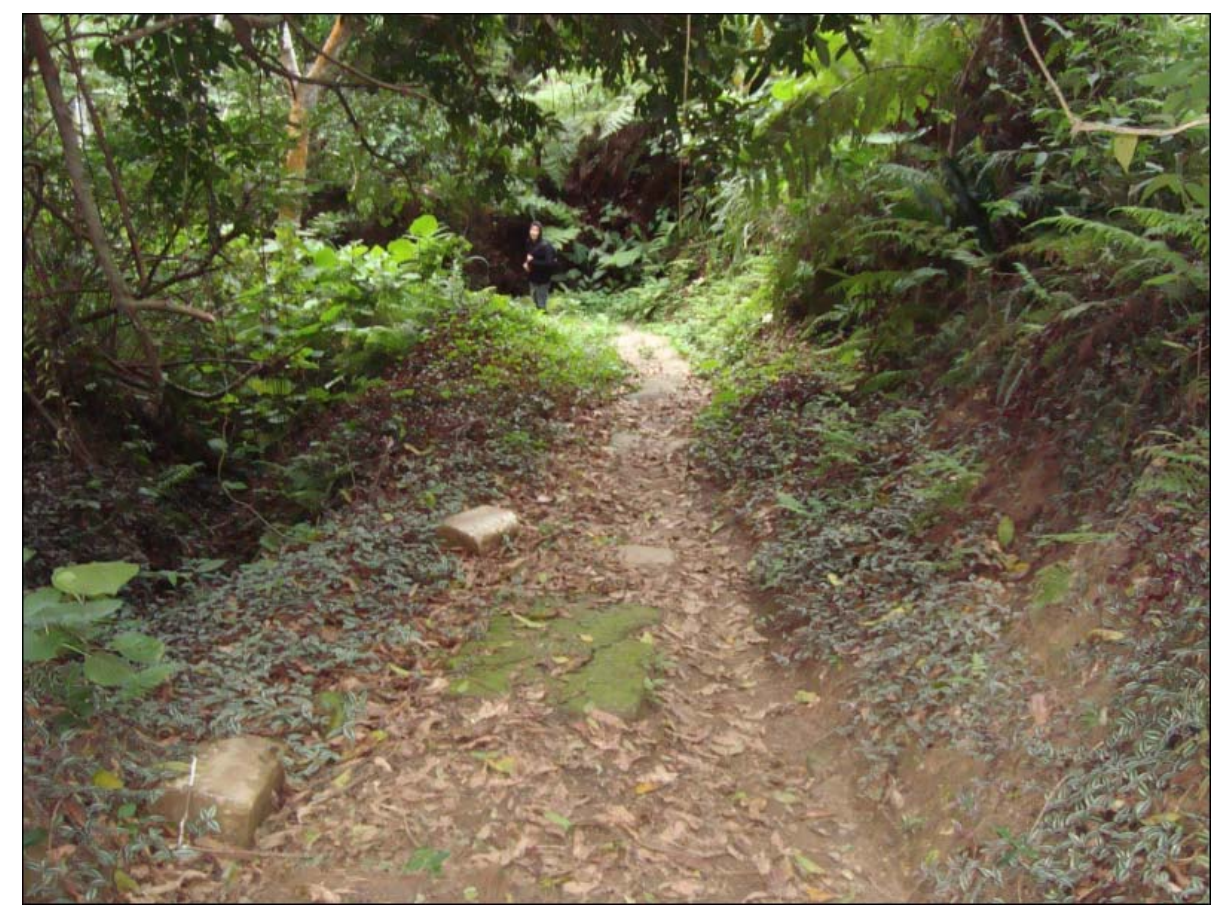

Figura 75 - Trilha de acesso à Ponta do Pasto, a oeste do Forte do Leme

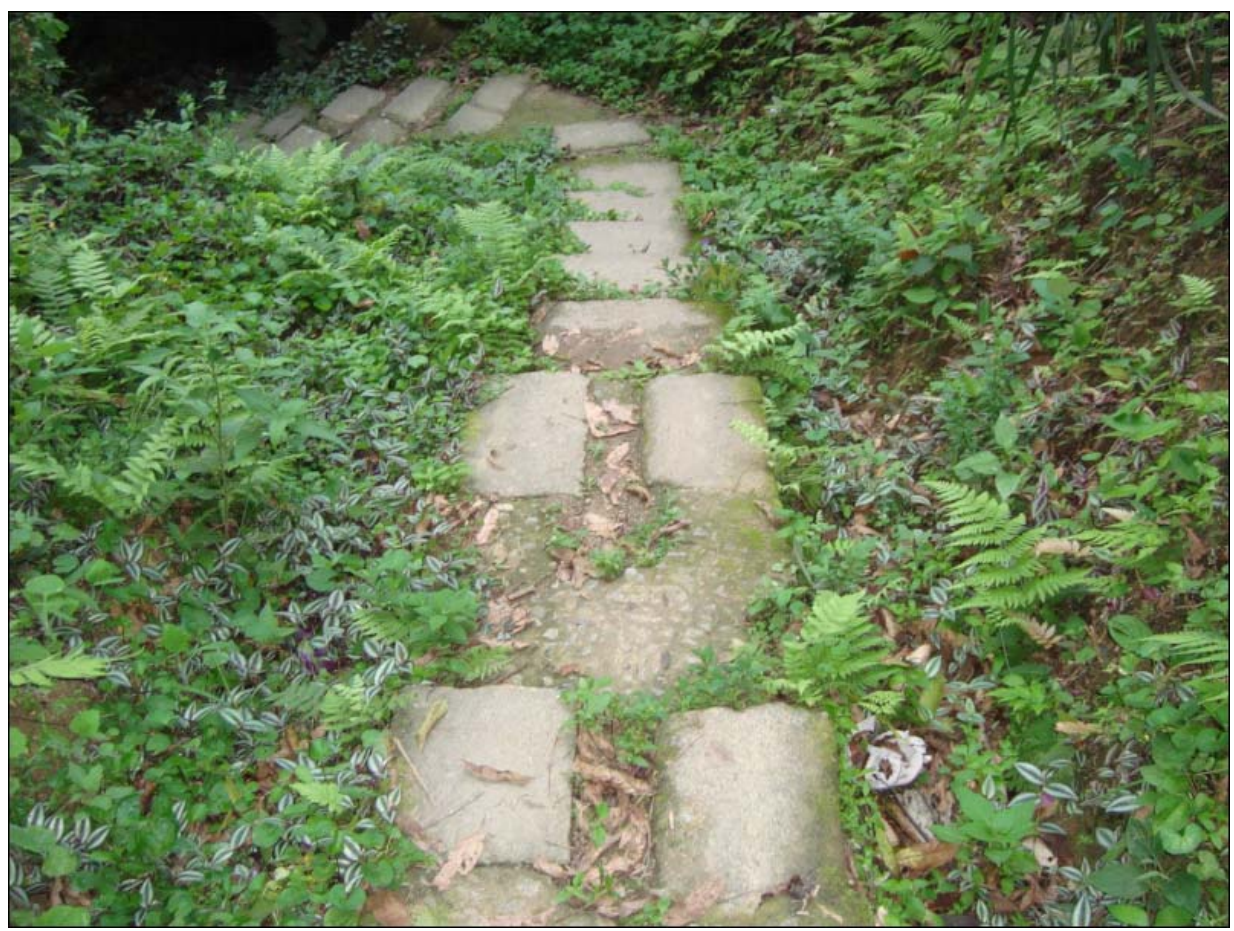

Figura 76 - Escada de acesso ao Píer da Petrobrás (Ponta do Pasto) 
A mesma questão acontece no morro onde está implantando o Forte do Leme. Este morro, para a construção do Forte, foi terraplanado. O mesmo é um costão rochoso extremamente íngreme, com $82 \mathrm{~m}$ de altitude, o que também inviabiliza qualquer operação de deslocamento de material e acesso vindos do mar.

Outra opção poderia ser descarregar o material na enseada que contempla a outra lateral do Forte, a leste. Essa, talvez, seria a maneira mais acertada, porque a subida é menos íngreme do que as anteriores. É importante dizer que atualmente há uma trilha que liga a enseada à fortificação, de aproximadamente $500 \mathrm{~m}$ em linha reta, utilizada pelos moradores da região (figura 77). Mais importante ainda, essa mesma trilha é a que dá acesso às estruturas de pedra seca que foram identificadas próximas ao mar. Talvez, da mesma forma que houve uma defesa nesse local em tempos coloniais, o mesmo foi reutilizado, agora como "estrada de acesso" para alcançar o Forte do Leme ou para levar os materiais de construção até o alto do morro.

O que reforça essa hipótese é a própria distribuição das estruturas que compõem o Forte do Leme. Como descrevemos anteriormente, essa fortificação é formada por: banheiro, quartel, galerias subterrâneas, retaguarda e Casa do Comandante, sendo esta última, a única construção deslocada do esquema (ver figura 54).

Pensando nas estratégias defensivas e nas possibilidades de acesso ao Forte, em caso de ataque, a principal área a ser defendida poderia ser a retaguarda, pois nela se encontram o paiol e também a artilharia. Por esse motivo, os muros da retaguarda apresentam seteiras e a visão dessas seteiras do lado interno (onde ficaria o atirador) é o quartel. Essa informação pode indicar que, em um ataque pelo acesso da enseada da Ponta do Leme, o banheiro e o quartel seriam os primeiros cômodos a serem alcançados (figura 78 e 79) e a retaguarda, o ponto de refúgio (figura 80). Além disso, de acordo com a interpretação deste acesso ao Forte, a Casa do Comandante seria a construção mais protegida, porque foi construída, propositadamente, do lado oposto à enseada de acesso.

Entretanto, caso o acesso à fortificação fosse pela Ponta do Pasto, o contrário iria ocorrer, ou seja, a primeira construção invadida seria a Casa do 


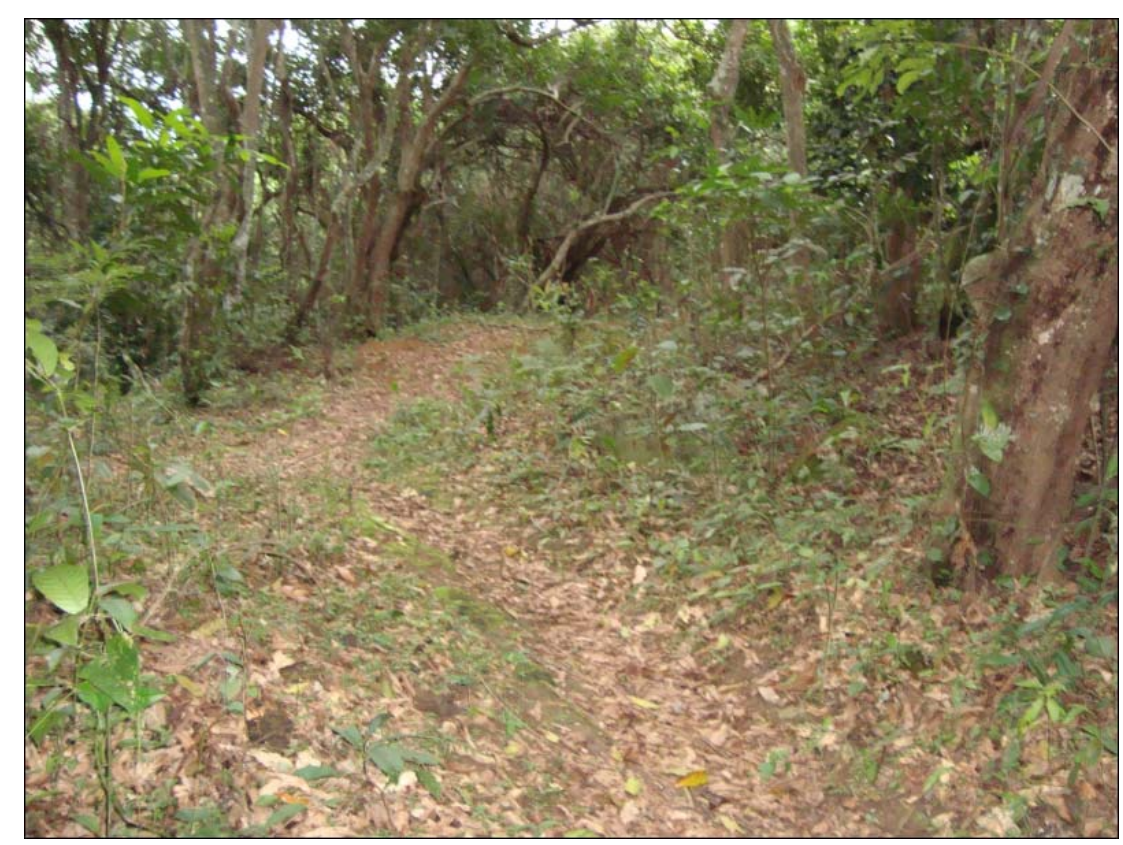

Figura 77 - Trilha que liga o Forte do Leme à Praia das estruturas, a leste

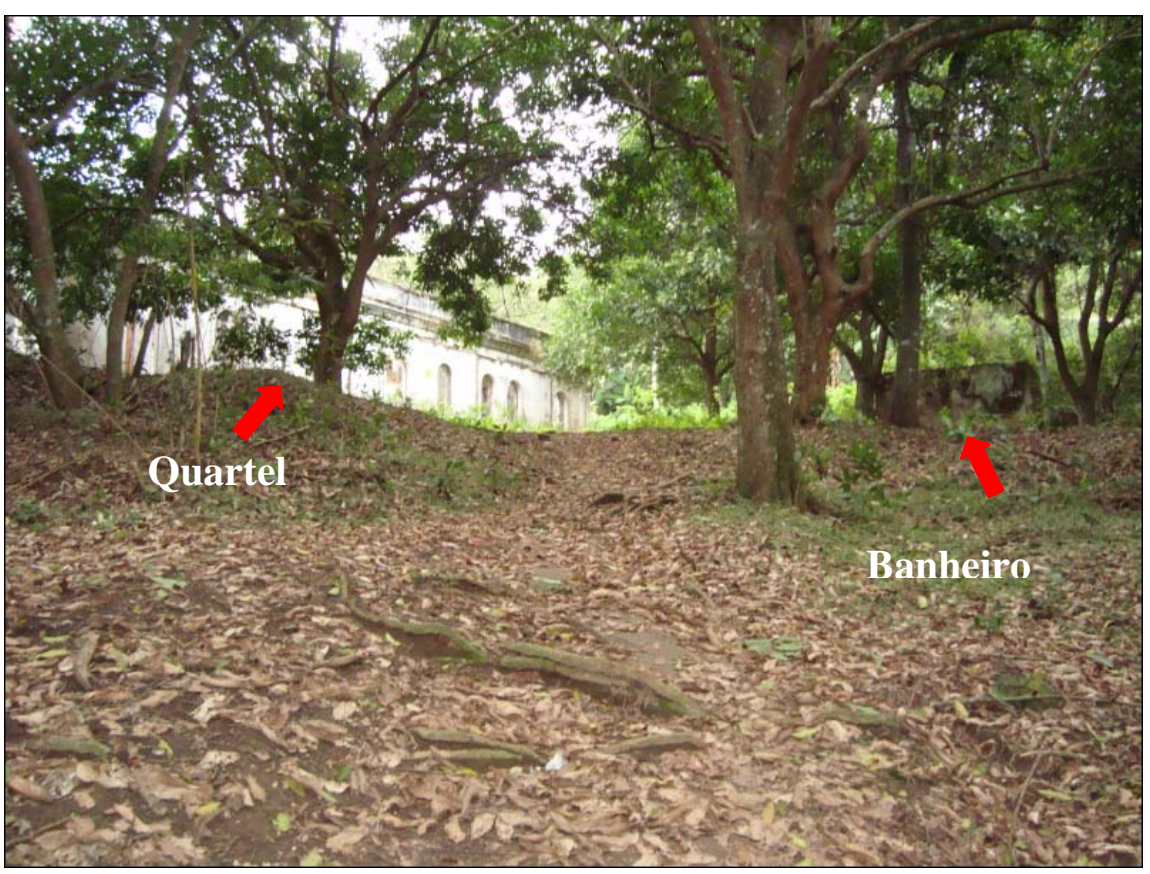

Figura 78 - Acesso ao Forte do Leme pela trilha leste 


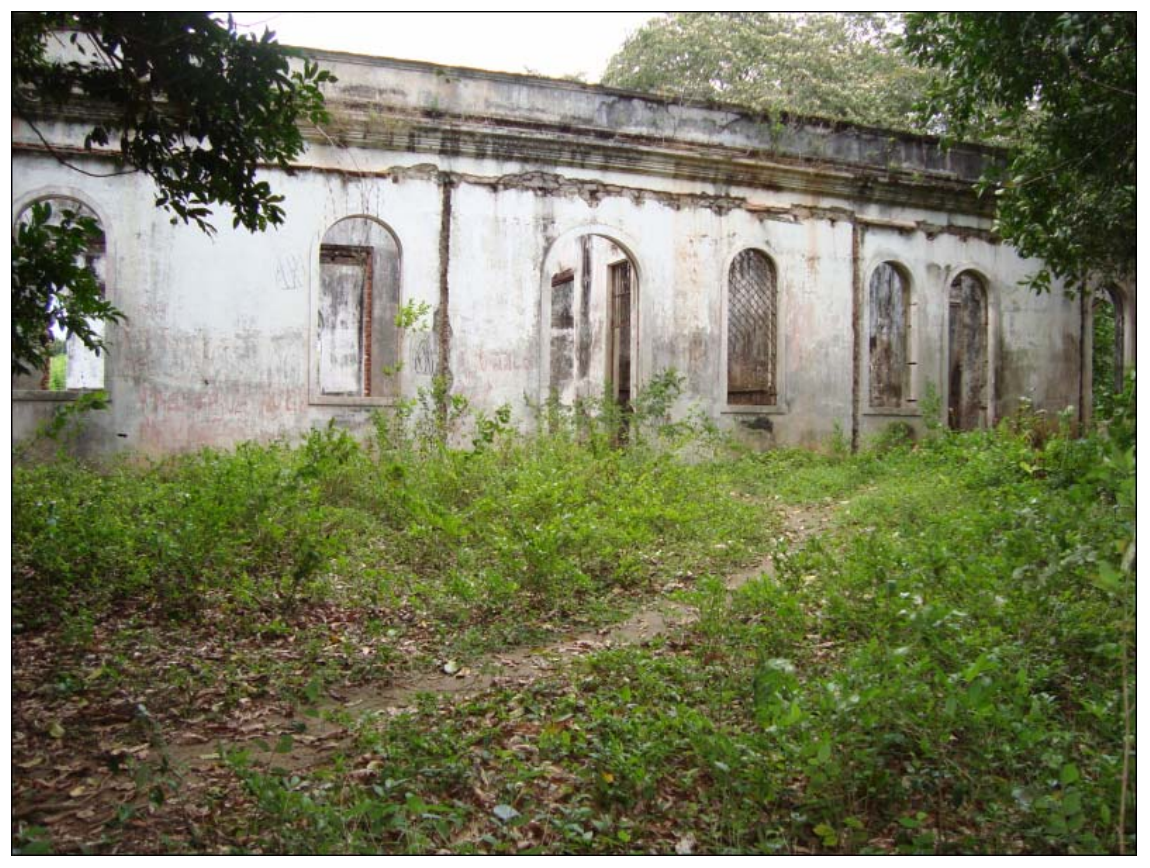

Figura 79 - Parte de trás do quartel

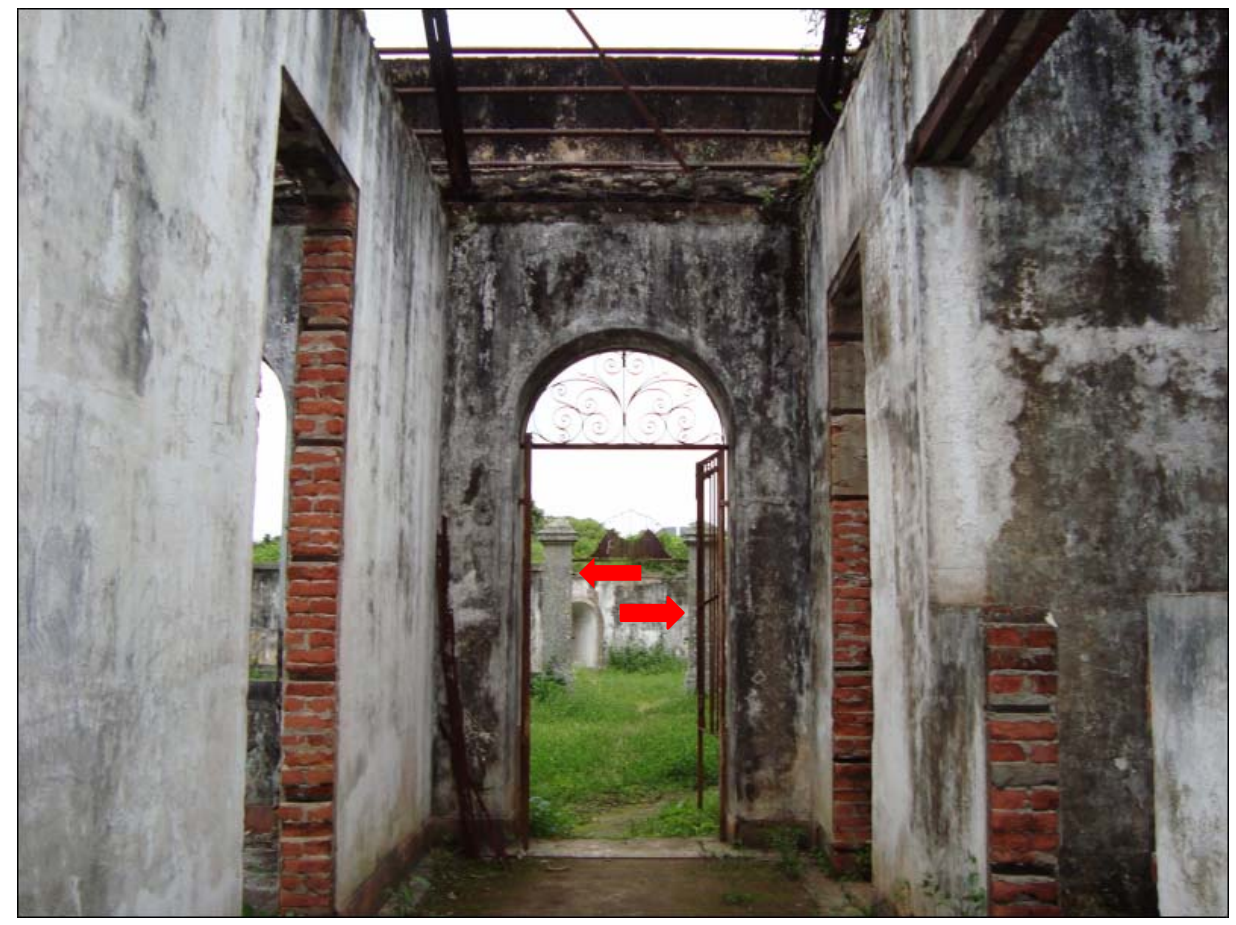

Figura 80 - Quartel com vista para a retaguarda, onde estão as seteiras 
Comandante, em seguida, a retaguarda e o quartel e, por fim, o banheiro, o que não teria sentido.

Embora estas considerações sirvam para indicar alguns aspectos relacionados à distribuição das estruturas que compõem o Forte do Leme, algumas questões permanecem obscurecidas. A hipótese mais provável de acesso ao Forte, a da enseada onde se encontram as estruturas mais antigas, indica também problemas em situação de ataque, como por exemplo, a vulnerabilidade do banheiro e do quartel. Cabe ainda lembrar que a paisagem sofreu alterações com a construção do píer da Petrobrás, local onde não é possível o acesso para verificação de outras trilhas ou caminhos que poderiam levar ao Forte do Leme. Assim, muitas questões não podem ser esclarecidas por completo, mas apenas algumas reflexões foram apresentadas para tentar compreender esta distribuição. Segue abaixo as coordenadas geográficas do Forte do Leme:

\begin{tabular}{|l|l|}
\hline Quartel & $\mathrm{S} 23^{\circ} 03^{\prime} 13,1^{\prime \prime} / \mathrm{W} 044^{\circ} 14^{\prime} 11,7^{\prime \prime}$ \\
\hline Retaguarda & $\mathrm{S} 23^{\circ} 03^{\prime} 13,6^{\prime \prime} / \mathrm{W} 044^{\circ} 14^{\prime} 12,3^{\prime \prime}$ \\
\hline Canhão 1 & $\mathrm{S} 23^{\circ} 03^{\prime} 14,4^{\prime \prime} / \mathrm{W} 044^{\circ} 14^{\prime} 12,9^{\prime \prime}$ \\
\hline Canhão 2 & $\mathrm{S} 23^{\circ} 03^{\prime} 15,3^{\prime \prime} / \mathrm{W} 044^{\circ} 14^{\prime} 12,8^{\prime \prime}$ \\
\hline Casa do comandante & $\mathrm{S} 23^{\circ} 03^{\prime} 09,3^{\prime \prime} / \mathrm{W} 044^{\circ} 14^{\prime} 19,6^{\prime \prime}$ \\
\hline
\end{tabular}




\section{As estruturas defensivas de pedra seca}

Na segunda etapa de campo em Angra dos Reis, além da descrição dos canhões e da inspeção visual feita no Morro da Fortaleza, fizemos o reconhecimento, limpeza, sondagem, descrição e desenho das estruturas defensivas encontradas na Ponta Leste. Podemos citar ainda o levantamento sistemático de superfície, realizado em níveis mais elevados do local onde se encontram estas estruturas. Abaixo relacionamos as quatro estruturas encontradas na área próxima ao Forte do Leme.

\section{Estrutura 1}

Esta estrutura de pedra seca (pedra sobreposta) localiza-se em uma enseada próxima ao Forte do Leme (figura 81). A mesma encontra-se a $3 \mathrm{~m}$ de altitude e está sofrendo uma descaracterização, devido à ação de pessoas que acampam no local. Dentre essa descaracterização, identificamos uma grelha e uma lixeira, improvisada com um copo de plástico, utilizando a estrutura como suporte. Além disso, há presença de lixo, em grande quantidade, formado por várias garrafas de plástico e de vidro, pilhas entre outros (figura 82).

A estrutura 1 está orientada para Nordeste e a distância, em linha reta, da Ilha Grande é de 3,7 Km. Devido a grande extensão da estrutura 1,31 m aproximadamente, e a grande quantidade de lixo a ela associada, foram escolhidos dois locais para limpeza e sondagem. A primeira face está cerca de $4 \mathrm{~m}$ de seu início. Na sondagem da parte inferior da face 1 desta estrutura, encontramos, além de muito lixo, fragmentos de telha, já na superfície (figura 83). Na mesma altura, fizemos uma sondagem (1x1 m) na parte de cima para verificar sua espessura aproximada e, nesta sondagem, foram encontradas várias pedras, que podem indicar um piso (figura 84). Há também muito material plástico. A altura aproximada desta face é de 1,48 m e sua distância do mar é de 8,60 metros.

A segunda face escolhida para a limpeza e sondagem de 2x2 m está localizada a, aproximadamente, 8,70 $\mathrm{m}$ do início da estrutura. Foi encontrada na parte superior grande quantidade de fragmentos de telhas e de pedras 


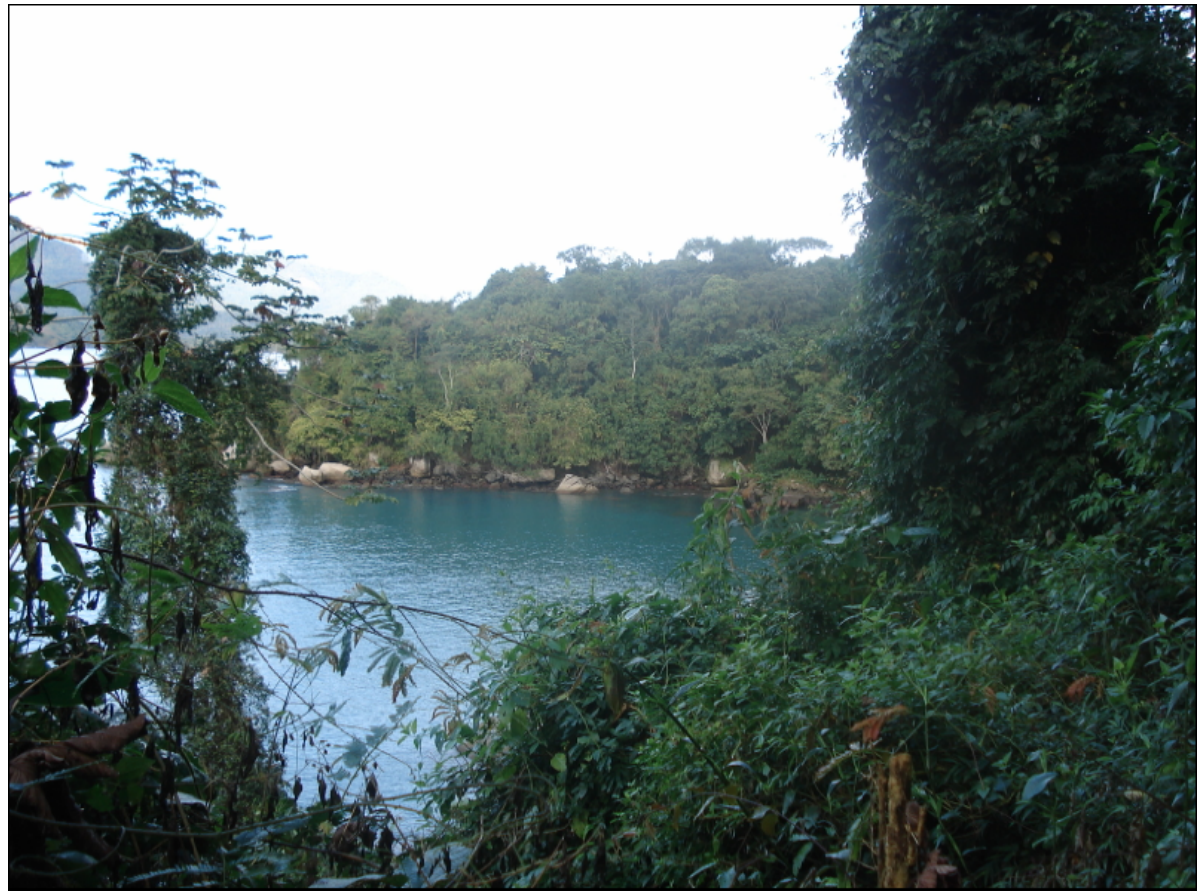

Figura 81 - Trilha para a praia onde se encontram as estruturas

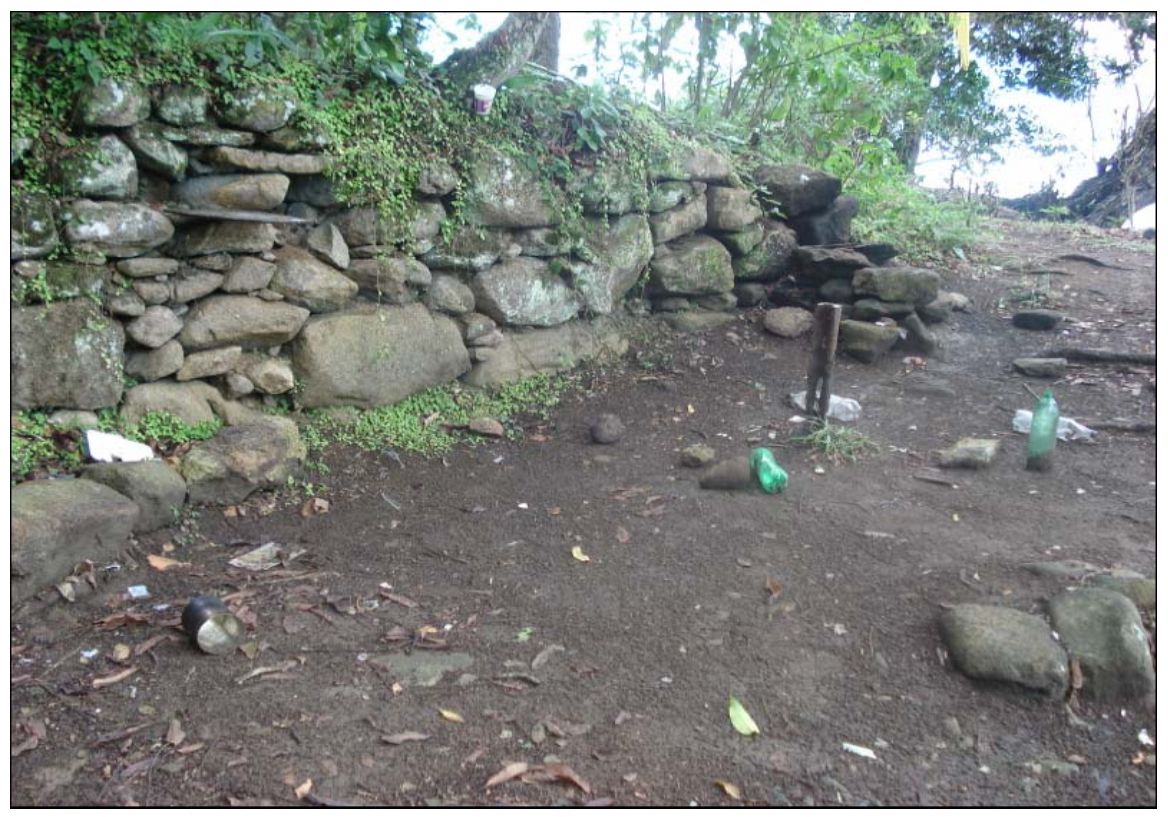

Figura 82 - Descaracterização da estrutura 1 


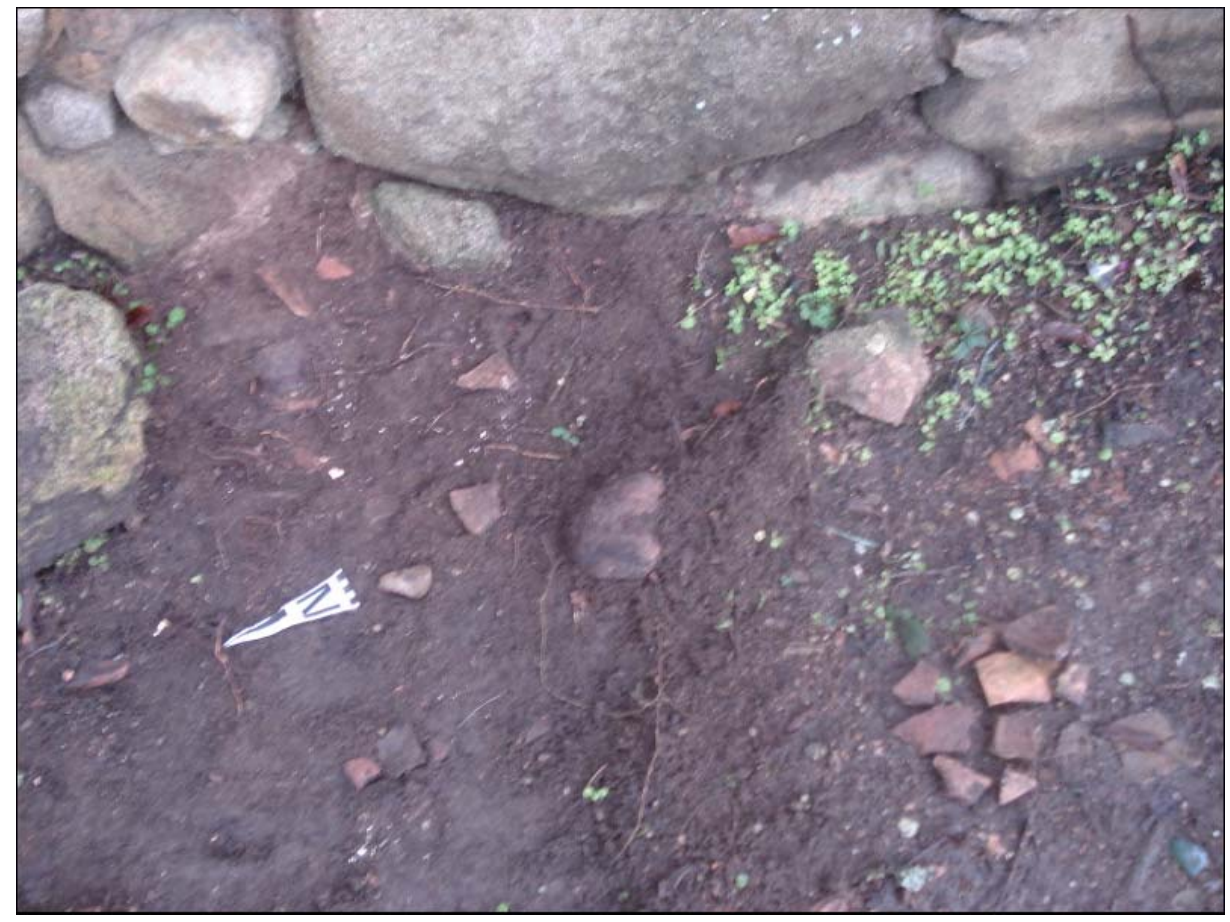

Figura 83 - Sondagem na parte inferior - face 1 - estrutura 1

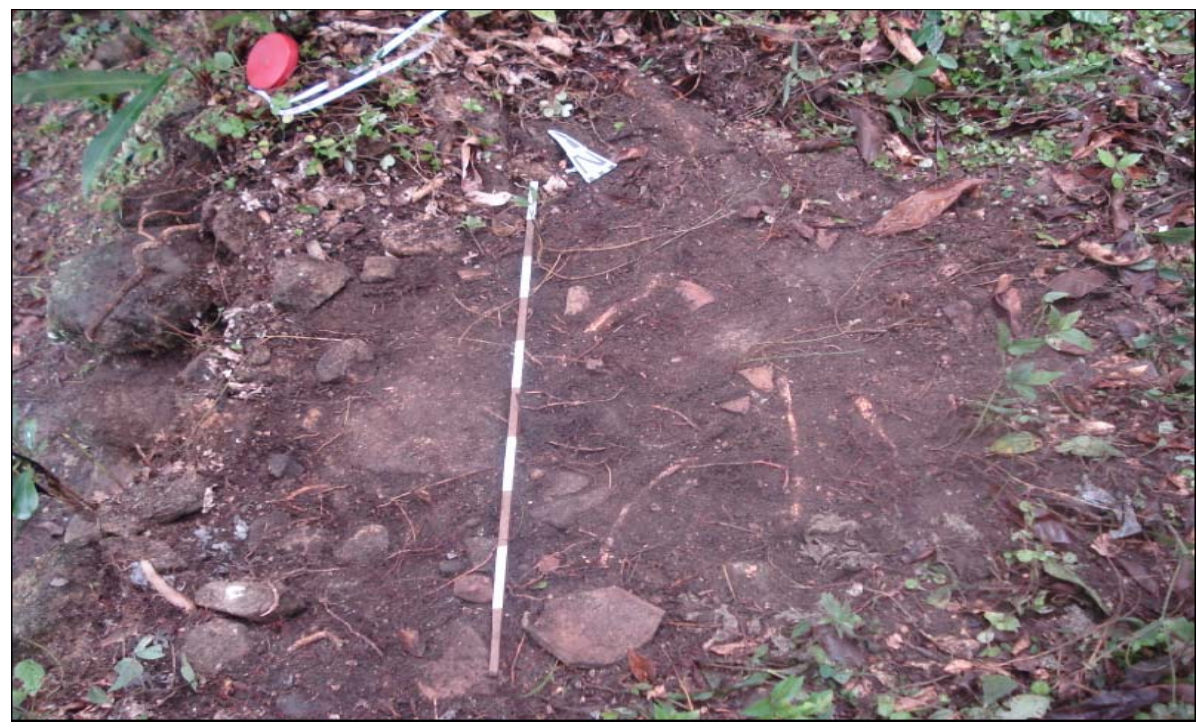

Figura 84 - Sondagem na parte superior - face 1 - estrutura 1 
pequenas. A 9,70 $\mathrm{m}$ de seu início, no seu topo, há uma pedra de $1 \mathrm{~m}$ de extensão. A sondagem foi feita atrás dela e esta acaba a 10,70 m do início da estrutura 1. Na base desta estrutura há também uma pedra, que provavelmente caiu do topo (este topo apresenta uma falha). A parte inferior não foi sondada porque está com bastante lixo (figuras 85 e 86). A altura aproximada desta face é de 1,90 m. A sua espessura só poderá ser indicada com uma escavação, devido a grande quantidade de pedras atrás da mesma.

Foi elaborado um esquema das duas faces sondadas na estrutura 1 (figura 87). Além disso, a coordenada geográfica desta estrutura é a seguinte (figura 91):

\begin{tabular}{|c|c|}
\hline Estrutura 1 & S $23^{\circ} 03^{\prime} 11,3^{\prime \prime} /$ W $44^{\circ} 13^{\prime} 52,9^{\prime \prime}$ \\
\hline
\end{tabular}

A estrutura 1 tem uma provável continuação, afetada por um desmoronamento, que chega até muito próximo da praia das Rochas. Neste sentido, fotografamos essa continuação e mostramos abaixo sua coordenada geográfica:

\section{\begin{tabular}{l|l|} 
Estrutura 1 continuação & $S 23^{\circ} 03^{\prime} 10,8^{\prime \prime} /$ W $44^{\circ} 13^{\prime} 53,6^{\prime \prime}$ \\
\hline
\end{tabular}}

Esta possível continuação da estrutura 1 está associada a um bambuzal. Mais próximo a este local foi tirado outro ponto de GPS, denominado Praia das Rochas, com as seguintes coordenadas: S $23^{\circ} 03^{\prime \prime} 09,6^{\prime \prime} / \mathrm{W} 44^{\circ} 13^{\prime} 56,2^{\prime \prime}$. Pelo fato desta continuação estar encoberta por vegetação e sedimento, não foi possível precisar a sua extensão (figuras 88,89 e 90).

Vale aqui destacar que a $26 \mathrm{~m}$ do início da estrutura 1, à frente, pedras estão distribuídas com certa regularidade, o que talvez possa indicar uma base, que pode ter servido como contenção do mar. Esta possível base apresenta 5,22 m de largura e 7,35 m de extensão.

\section{Estrutura 2}

A estrutura 2 (superior), com orientação para o Sul, possui $38 \mathrm{~m}$ de extensão e é relativamente irregular, já que respeita o contorno do morro e se ajusta à formação do litoral (conforme figura 101). A mesma termina em um costão rochoso e também apresenta duas bases (pedras distribuídas com certa regularidade), uma na parte de cima, com $5 \mathrm{~m}$ de extensão e $3 \mathrm{~m}$ de largura, e 


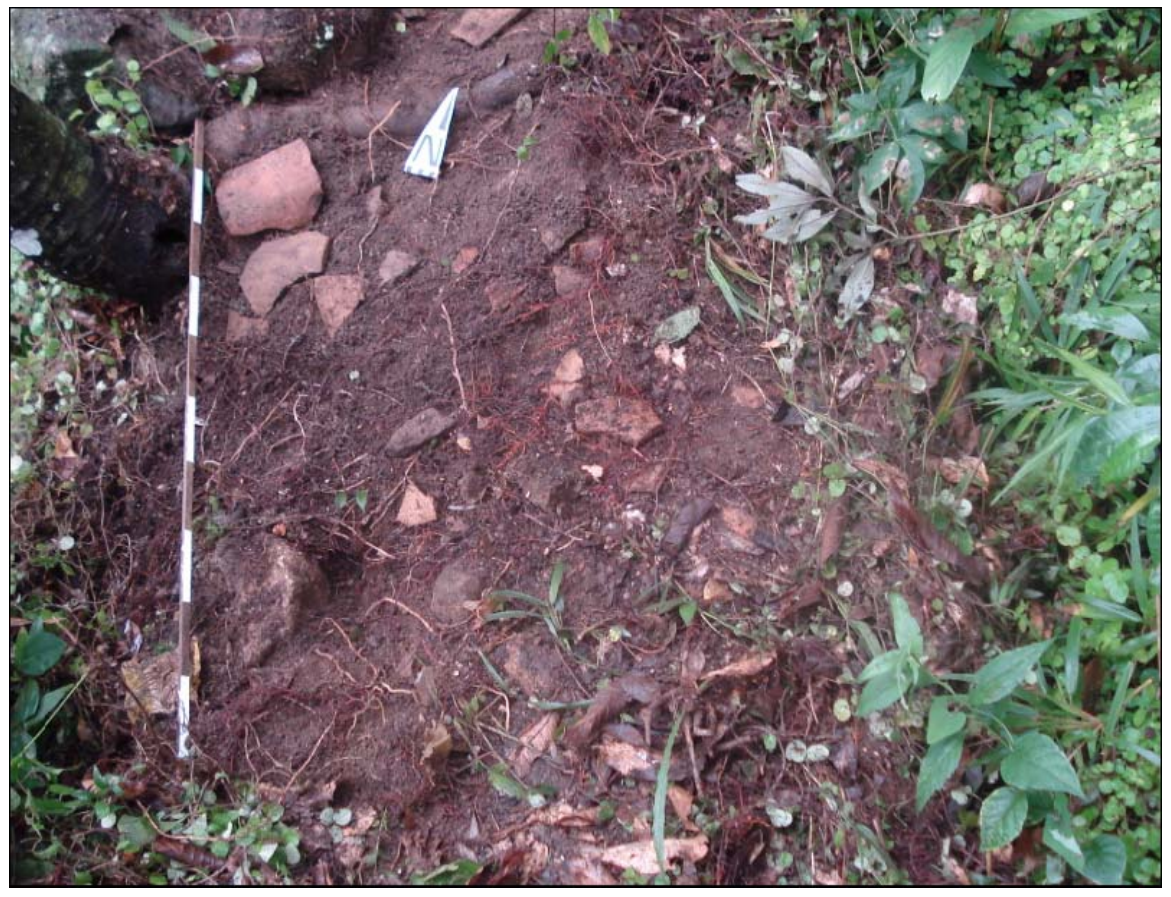

Figura 85 - Sondagem na parte superior - face 2 - estrutura 1

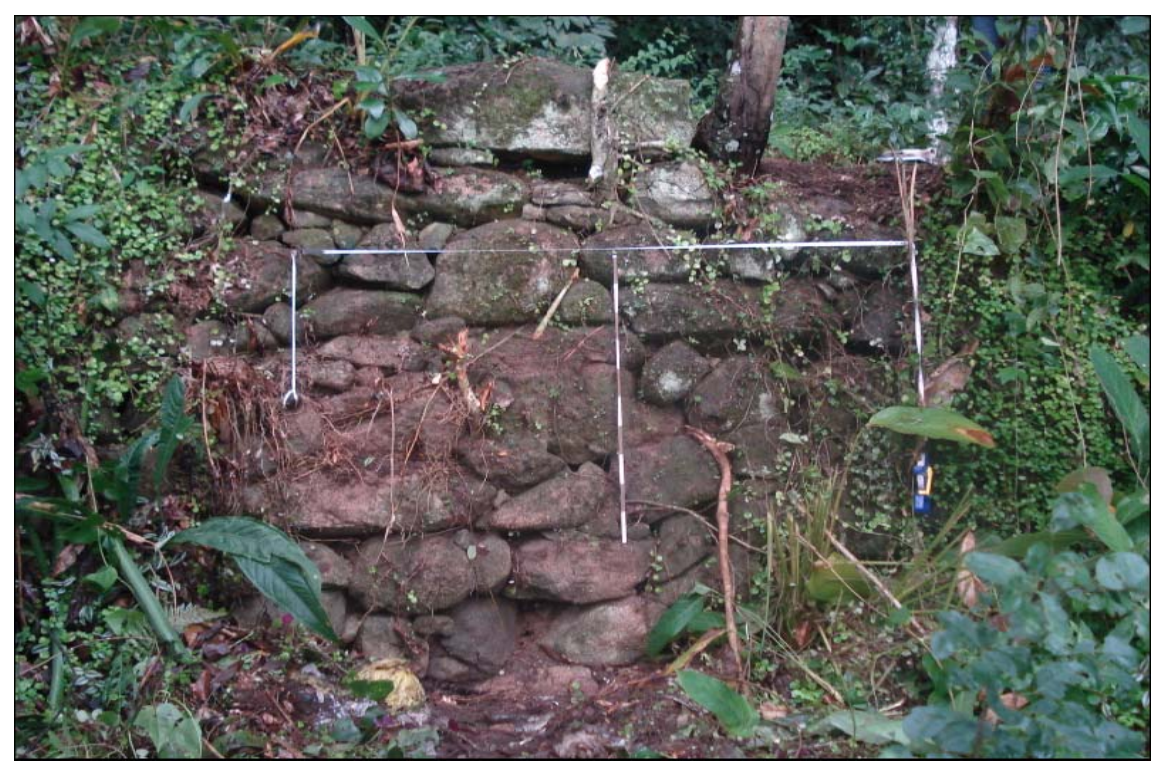

Figura 86 - Detalhe da face 2 da estrutura 1 - A parte inferior tem lixo acumulado 


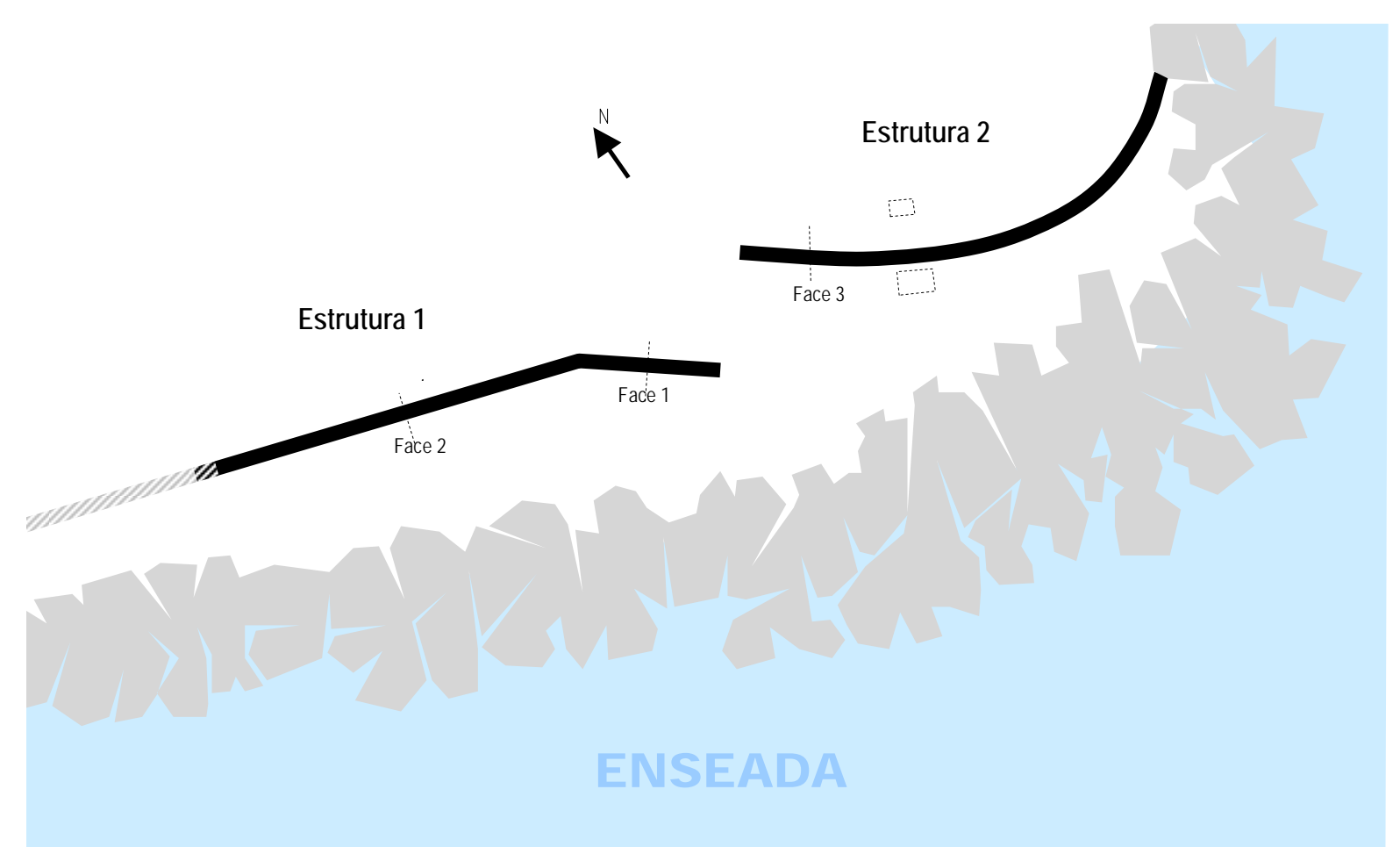

Estruturas de pedra seca

Provável continuação da Estrutura 1

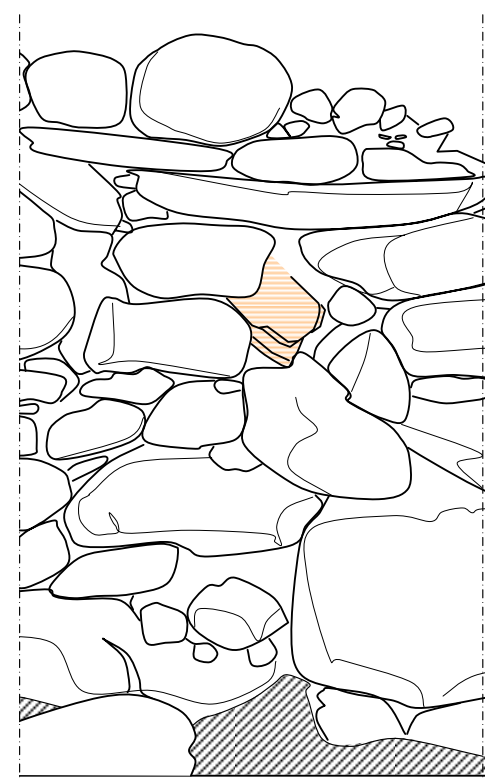

Face 1

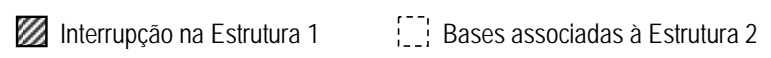

$\square$ Rochas e conjunto de pedras na praia

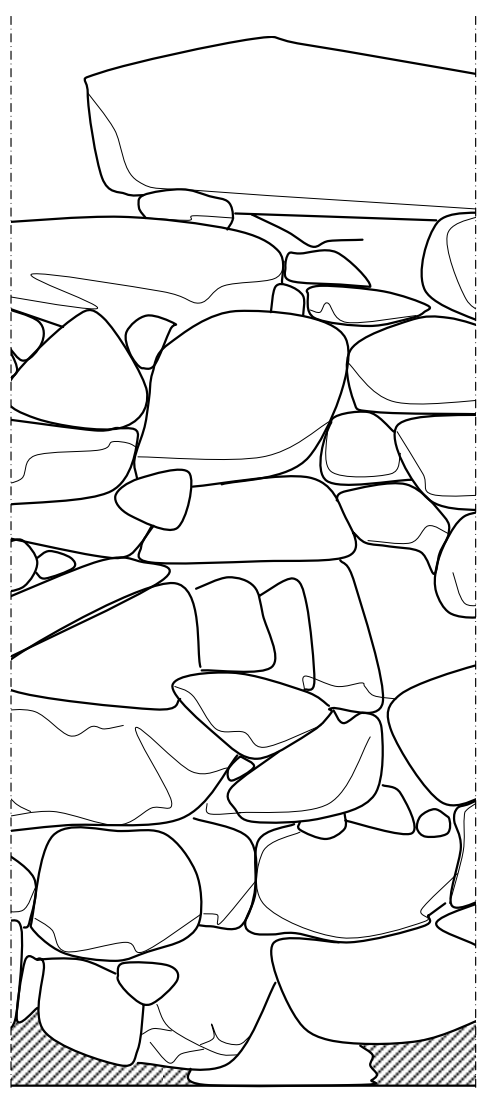

Face 2

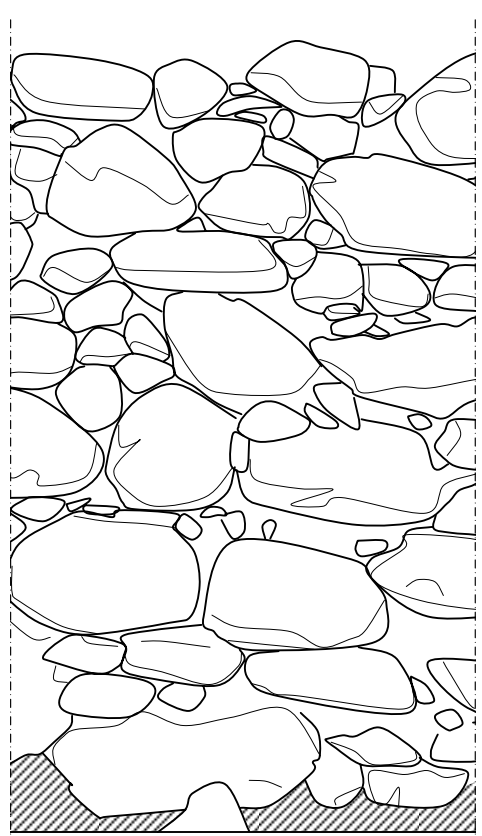

Face 3

Figura 87 - Esquema geral das estruturas e detalhes das faces 1 e 2, estrutura 1 e face 3, 

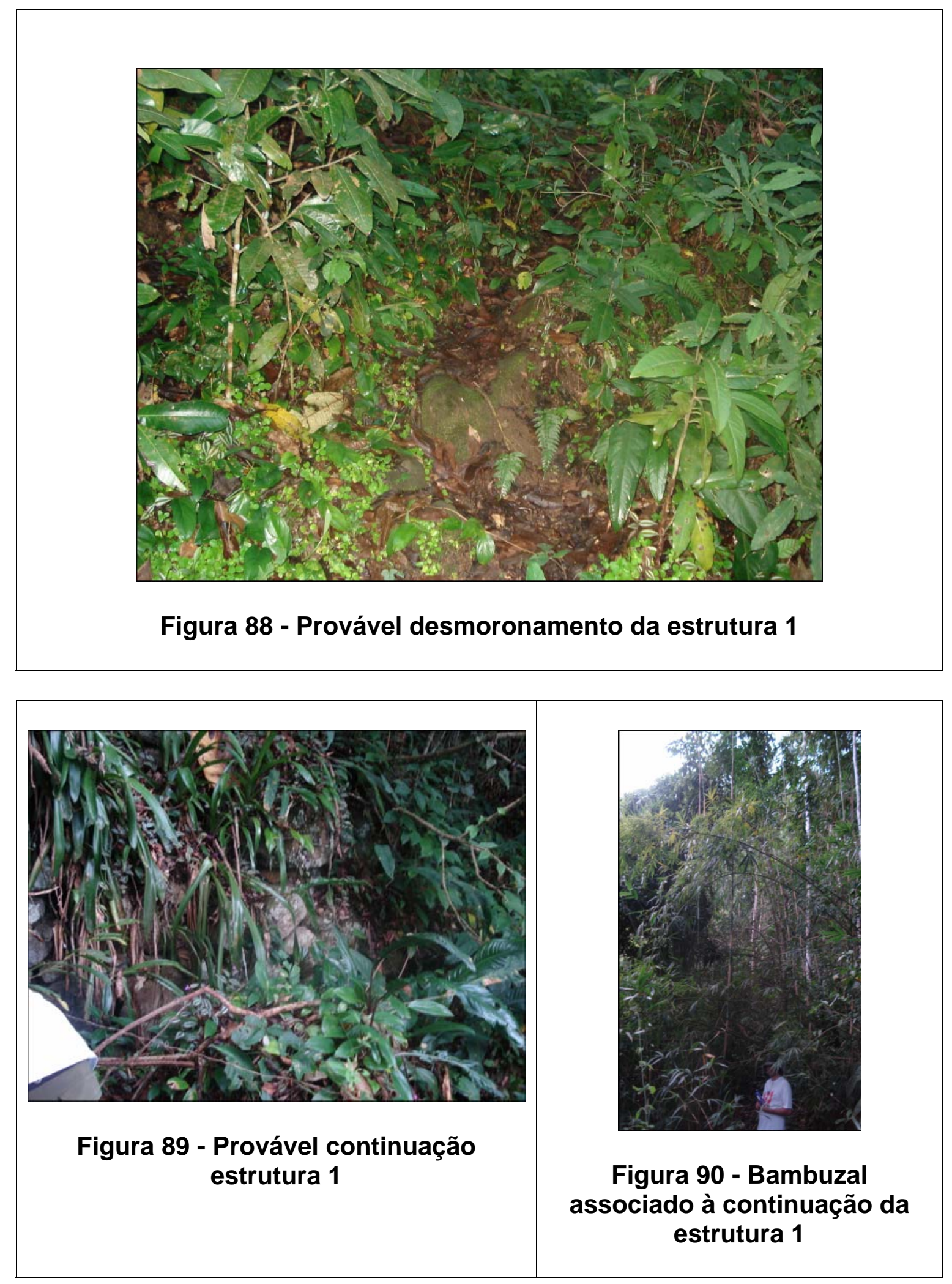


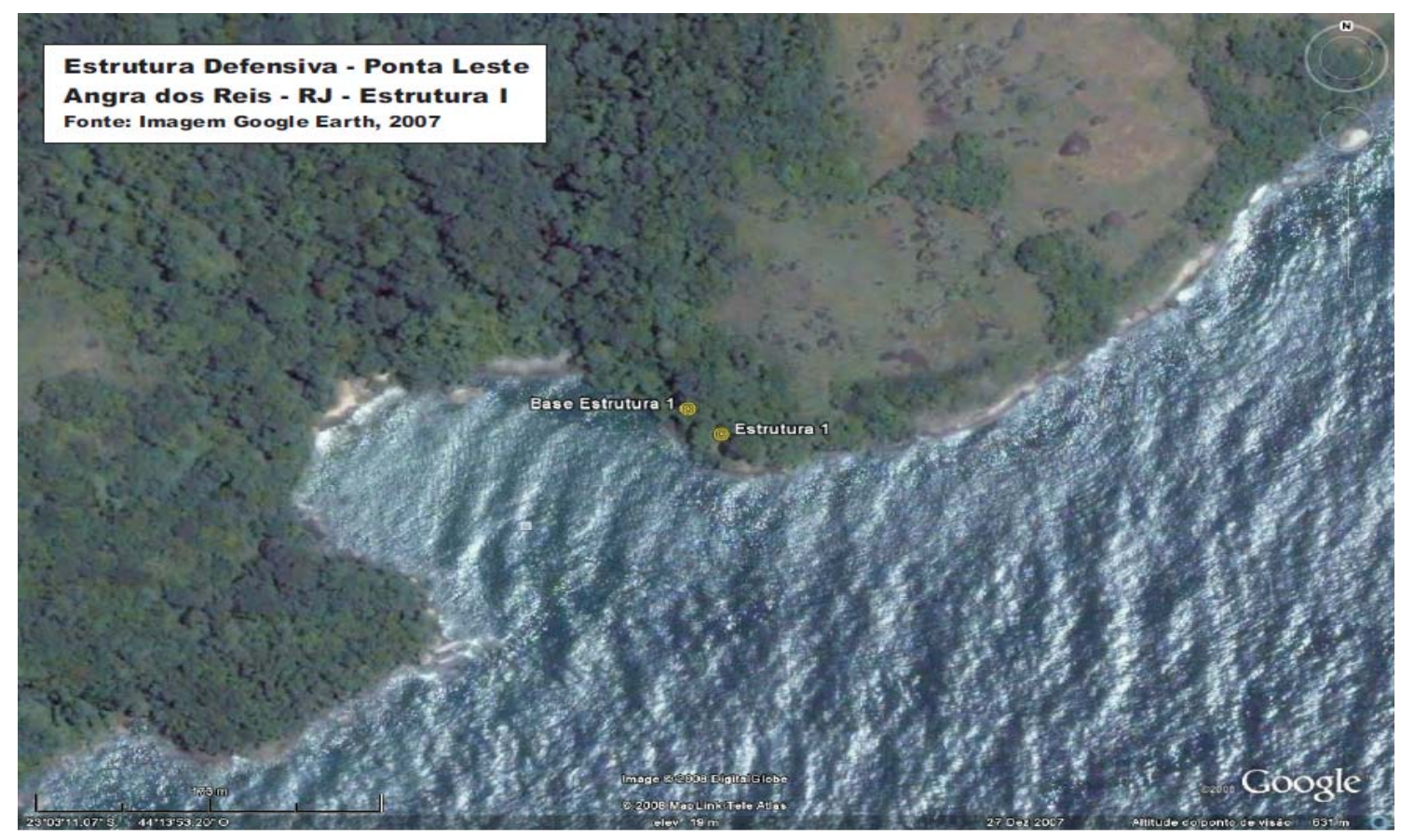

Figura 91 - Estrutura 1 
outra na parte de baixo, com 5,63 m de extensão e 2,70 m de largura. Segue abaixo sua coordenada geográfica:

\begin{tabular}{|l|l|} 
Estrutura 2 & $\mathrm{~S} 23^{\circ} 03^{\prime} 11,4^{\prime \prime} / \mathrm{W} 44^{\circ} 13^{\prime} 52,4^{\prime \prime}$ \\
\hline
\end{tabular}

Nesta estrutura foi feita uma sondagem a aproximadamente 5,5 $\mathrm{m}$ do seu início. Sondamos na parte alta até $1 \mathrm{~m}$ para trás, com 1,5 m de largura. Nesta sondagem também verificamos a presença de pedras menores, o que talvez possa ser identificado como um piso. Neste ponto não encontramos vestígios de telhas (figura 92).

Na sua parte inferior, na mesma altura da sondagem, há uma pedra que, provavelmente, desabou do topo. A base desta pedra foi a nossa referência para medirmos a altura aproximada desta face, que é de 1,80 m. Abaixo desta pedra há vestígios de uma fogueira (figuras 93 e 94). Importante aqui destacar que a estrutura 2, como é irregular, sua extensão também enquadra a vista para o lado da Marambaia e sua distância para a água do mar é de 13 m.

\section{Estrutura 4}

Esta estrutura foi identificada a partir do levantamento sistemático de superfície, realizado nesta etapa (ver figura 102). Nesse sentido, a estrutura 4 localiza-se do outro lado desta enseada, a 20 m de elevação. É uma estrutura de pedra seca que apresenta, aproximadamente, 32,80 m de extensão. Sua distância, em linha reta, do muro 1 é de 261 m e está orientada para Oeste (figuras 95, 96 e 97). Logo acima desta estrutura encontramos uma base feita em tijolos, que parece indicar a presença de uma antiga casa. Além disso, há blocos feitos de cimento, como se fossem baias ou tanques (figuras 98 e 99). A altura estimada desta estrutura, a partir do solo atual, varia entre 1, 50 e 2, 10 m e sua coordenada geográfica é a seguinte:

\begin{tabular}{|c|c|}
\hline Estrutura 4 & S 23 $03^{\prime} 13,6^{\prime \prime} / \mathrm{W} 44^{\circ} 14^{\prime} 1,4^{\prime \prime}$ \\
\hline
\end{tabular}

Neste lado da praia, no mar, tem um ancoradouro, já bastante corroído, que pode ter sido local de descarga dos materiais do Forte do Leme (figura 100), trazidos provavelmente por dois rebocadores. Esta praia permite uma excelente visibilidade do mar e também das estruturas 1 e 2. A coordenada deste local é:

\begin{tabular}{|l|l|} 
Ancoradouro do Forte & S $23^{\circ} 03^{\prime} 13,2^{\prime} /$ W $44^{\circ} 13^{\prime} 59,9^{\prime \prime}$ \\
\hline
\end{tabular}



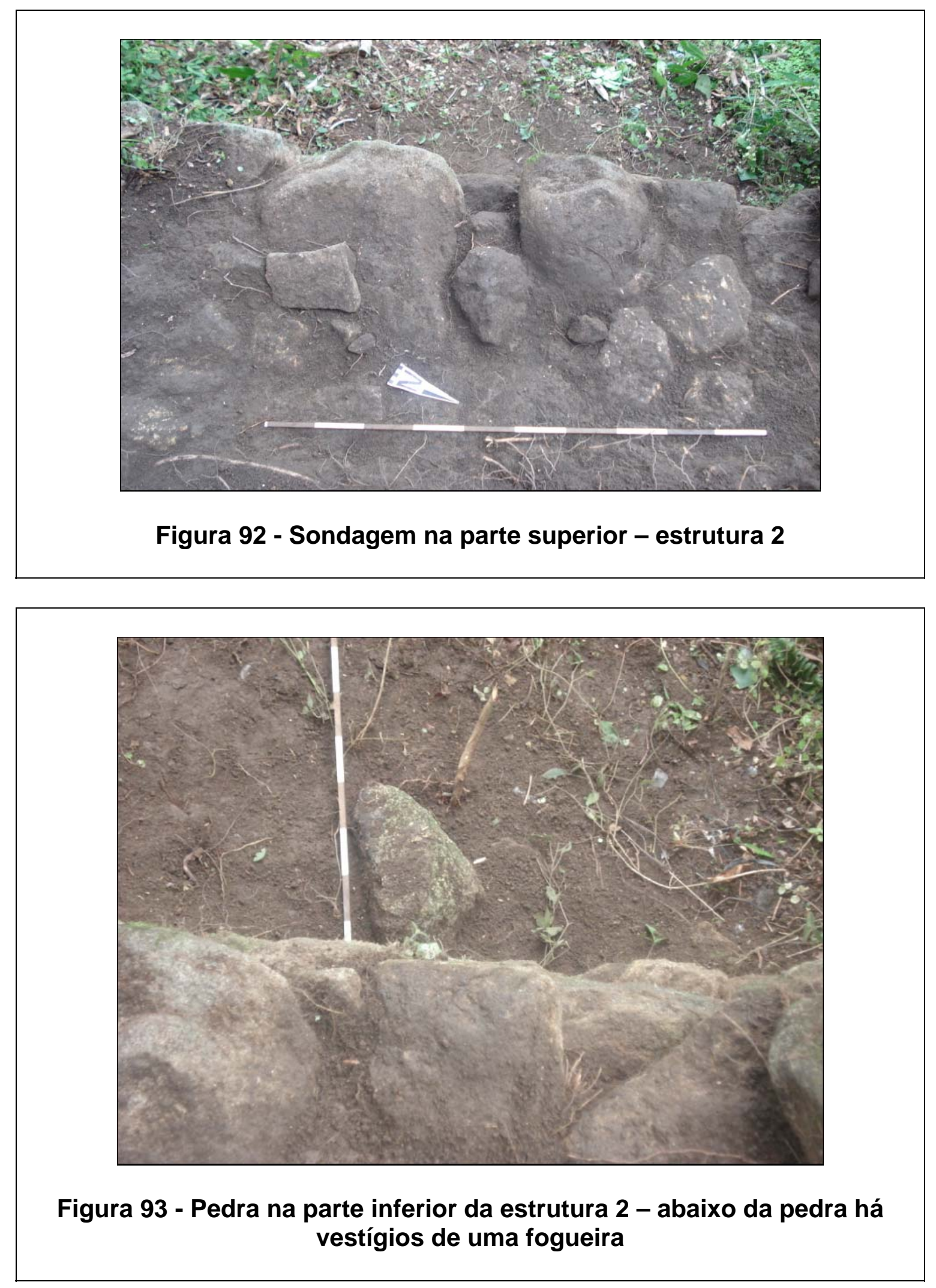


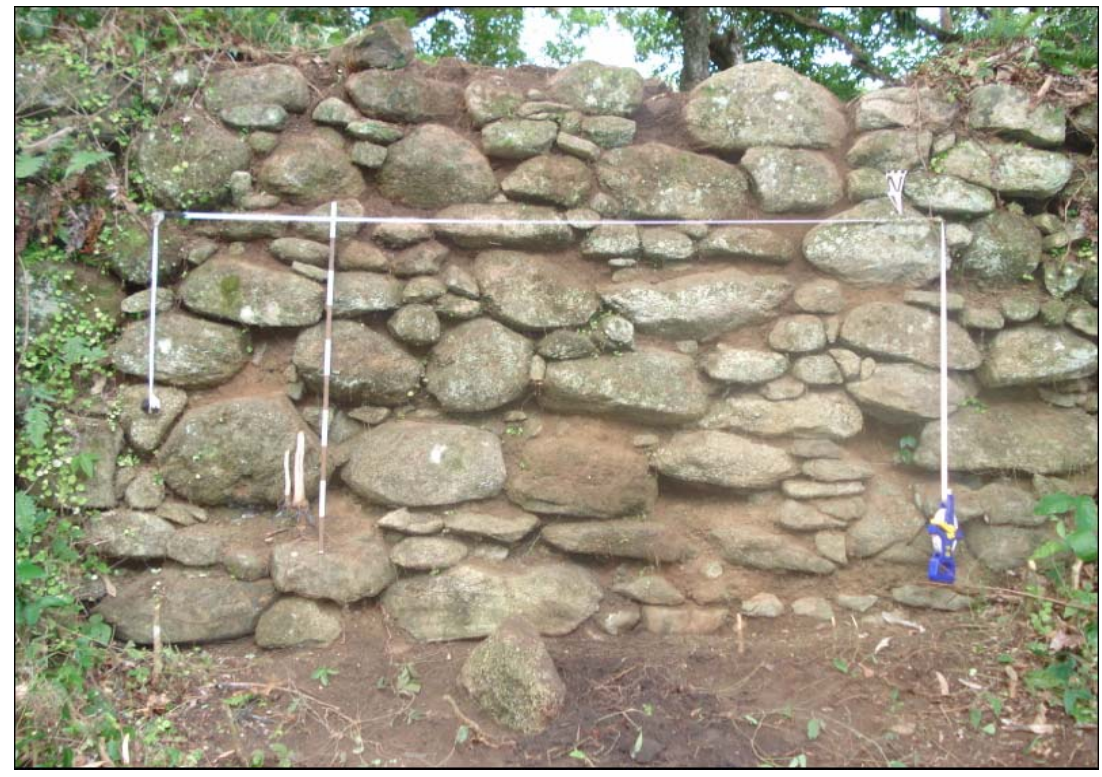

Figura 94 - Detalhe da face sondada na estrutura 2

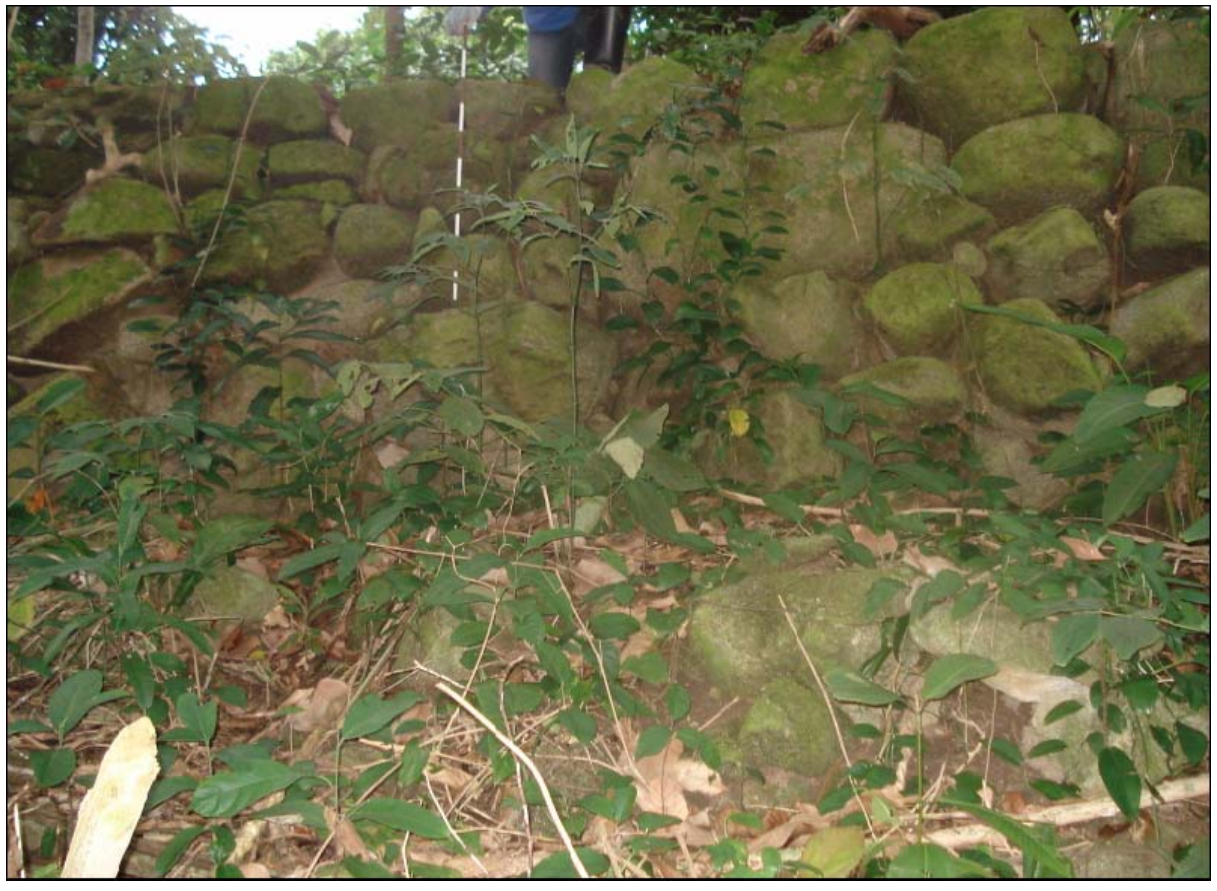

Figura 95 - Estrutura 4 

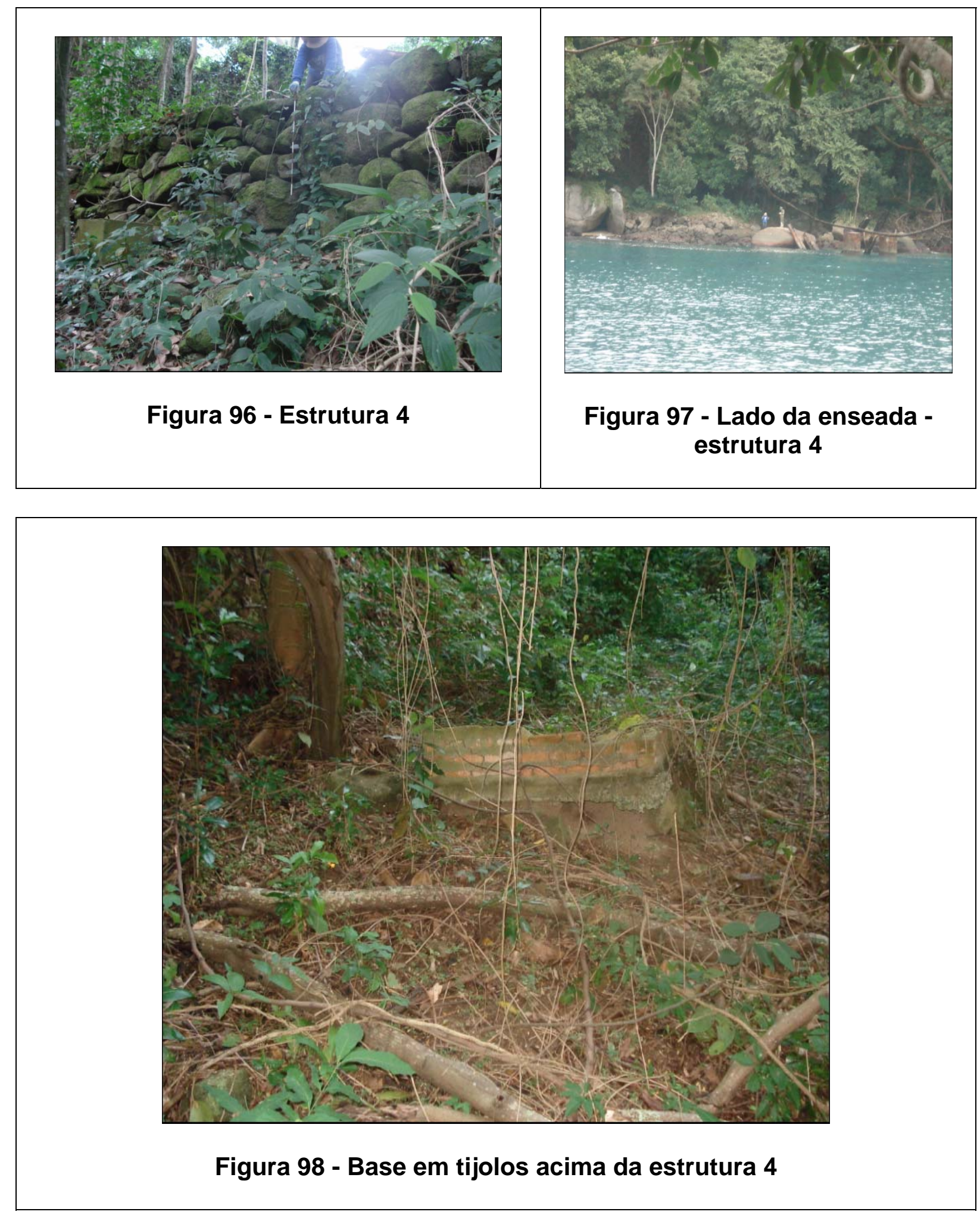


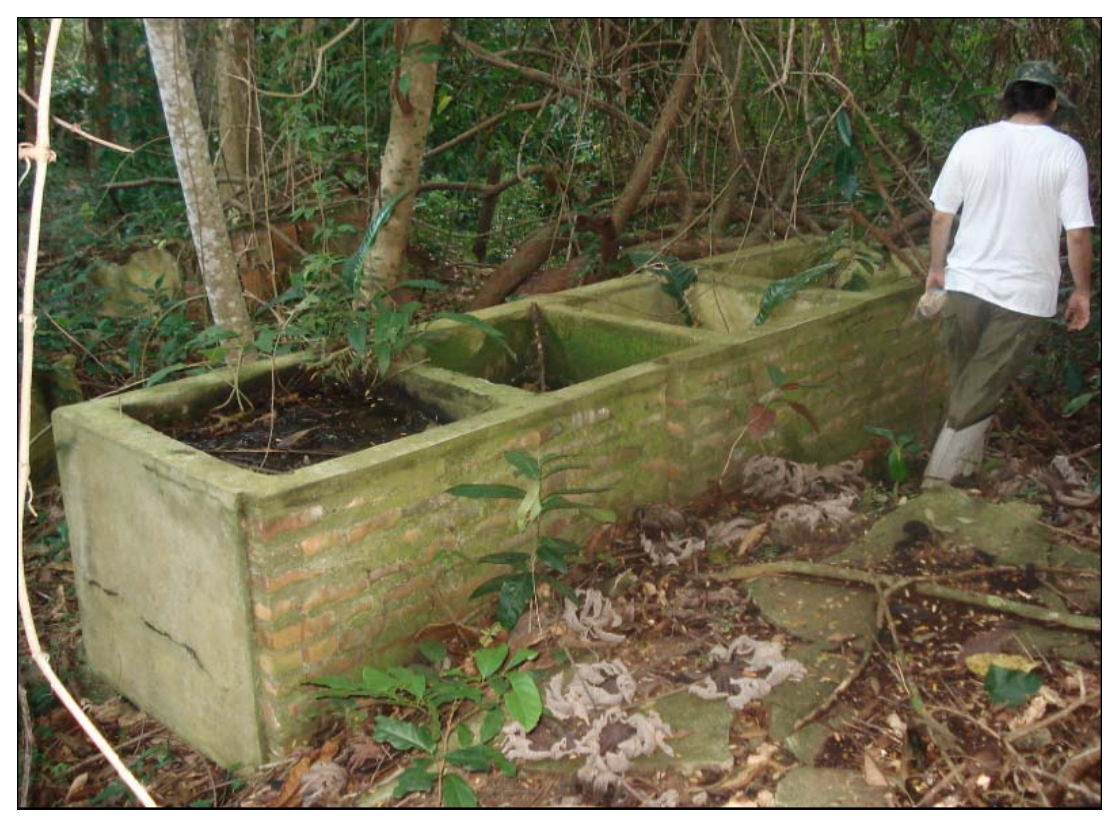

Figura 99 - Blocos de cimento acima da estrutura 4 (baias ou tanques)

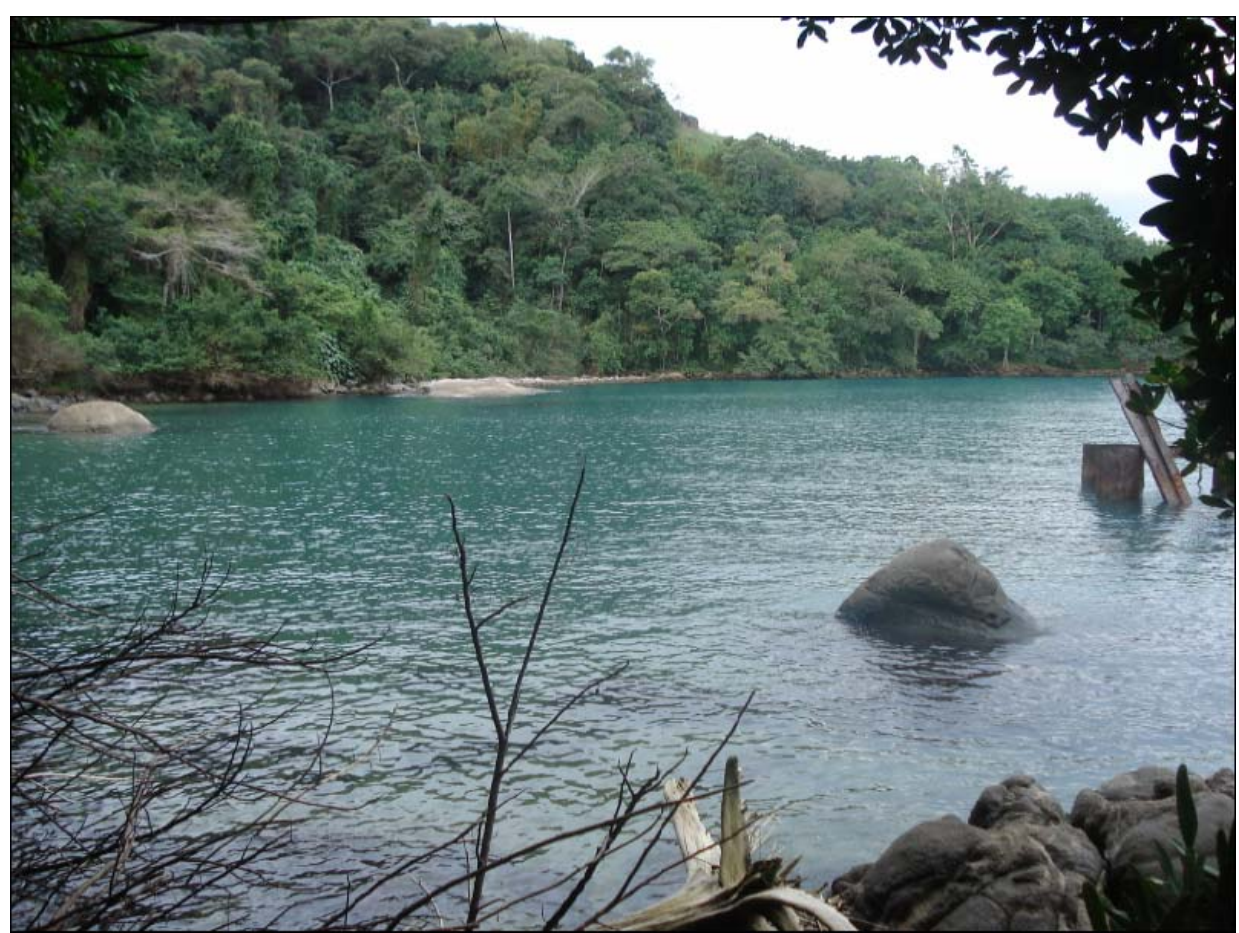

Figura 100 - Vista para as estruturas 1 e 2 e, à direita, possível ancoradouro 


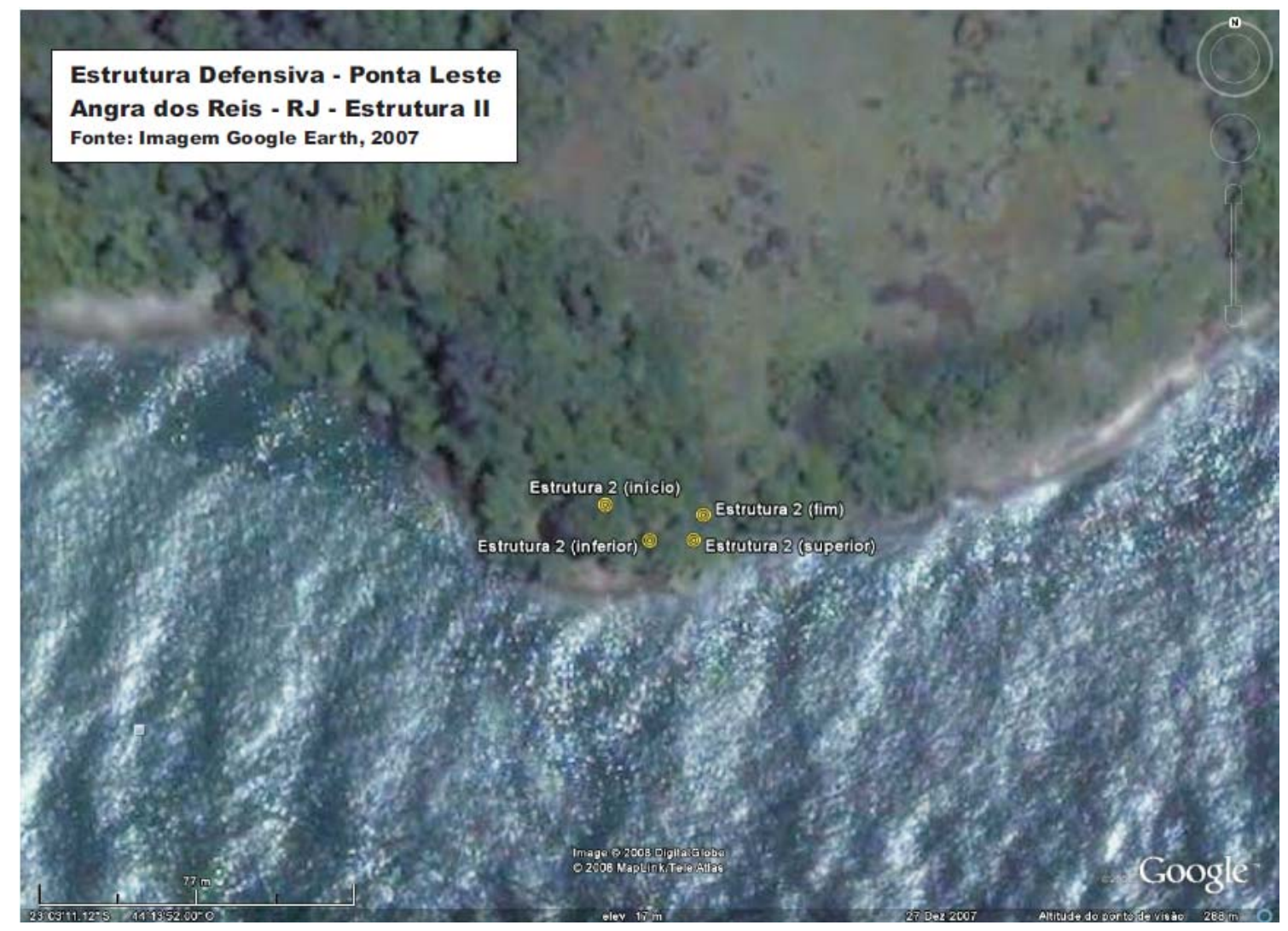

Figura 101 - Estrutura 2 


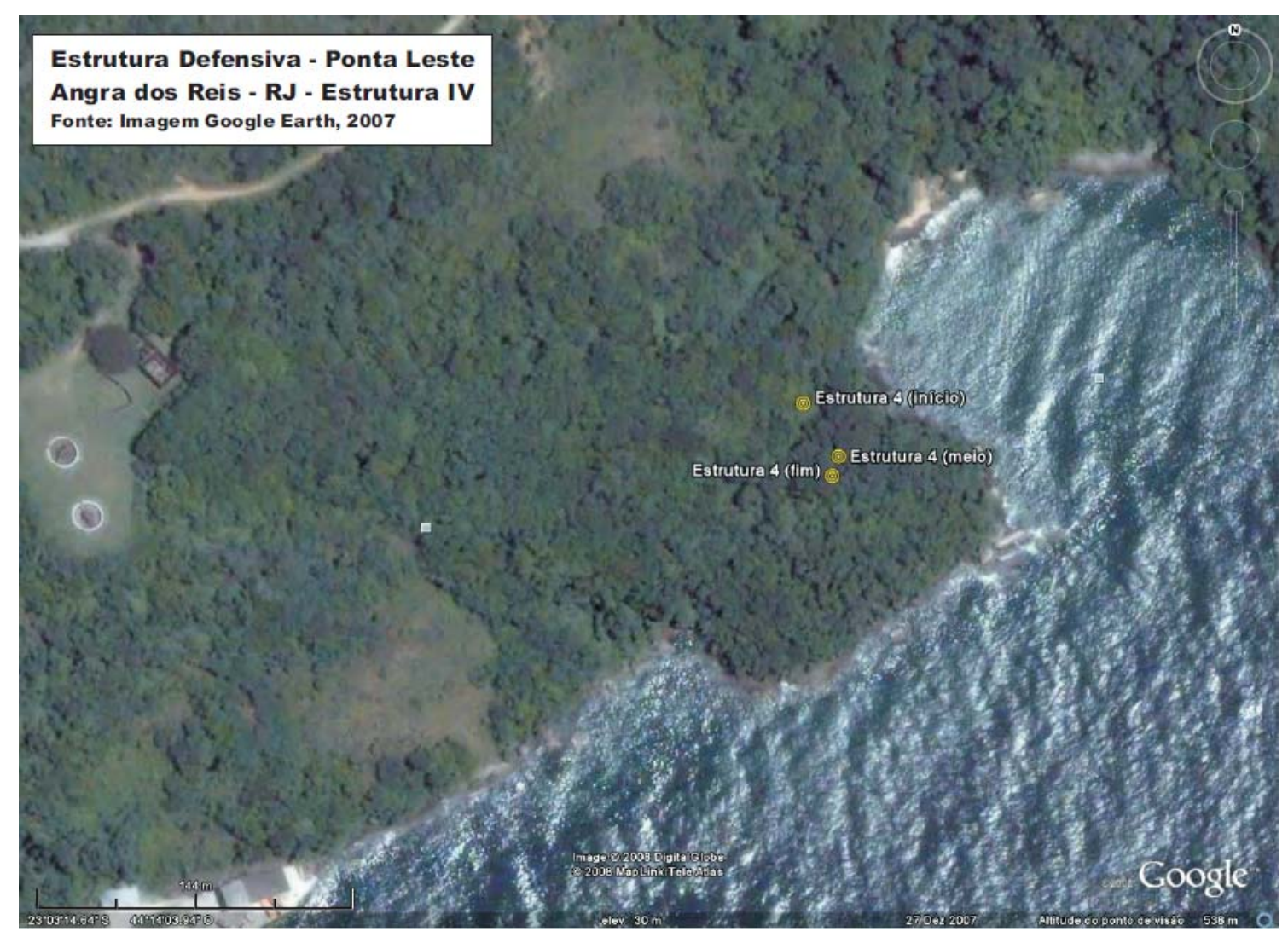

Figura 102 - Estrutura 4 


\section{As estruturas da Linha Férrea}

\section{Estrutura 3}

A estrutura 3 refere-se ao conjunto de pedras cortadas com argamassa, localizadas próximas às estruturas 1 e 2 (ver figura 116). Como são duas estruturas, estas foram identificadas como 3.1 e 3.2.

Fizemos limpeza destas estruturas. Na primeira conseguimos evidenciar a parte alta da face externa, porém, na parte inferior não foi possível, devido ao acúmulo de vegetação, o que dificulta medir sua altura. A estrutura 3.2, limpamos parcialmente, especialmente a área onde esta apresenta um ângulo. Pudemos perceber que ambas são provavelmente espelhadas e invertidas. A distância entre suas paredes externas (hoje formando o corredor de uma trilha) é de $2 \mathrm{~m}$. O comprimento das estruturas é de $6,45 \mathrm{~m}$ e os seus entalhes têm a largura de 4,15 m (figuras 103 a 107). A coordenada geográfica destas estruturas é:

\begin{tabular}{|c|c|}
\hline Estrutura 3 & S 23 $03^{\prime} 09,6^{\prime \prime} /$ W $44^{\circ} 13^{\prime} 53,9^{\prime \prime}$ \\
\hline
\end{tabular}

Cabe aqui destacar que informações orais indicam que essas estruturas faziam parte de um projeto para a construção de uma linha férrea, projeto que não chegou a ser finalizado.

A respeito deste assunto pouco podemos dizer, pois a leitura documental desta pesquisa foi voltada somente às questões defensivas da região. Entretanto, em consulta na internet ${ }^{84}$ identificamos a referência de uma ruína de antiga ferrovia, em local próximo a Ponta Leste. Assim, na terceira etapa de campo este local foi visitado.

\section{Estrutura Praia do Coqueiro}

O acesso a esta estrutura deu-se pela Praia dos Maciéis. A partir daí segue-se uma trilha até chegar à Praia do Coqueiro. Essa área foi ocupada por residências de luxo. Em conversa com um dos caseiros, o mesmo nos levou a esta antiga estrutura (figuras 108 e 109), hoje completamente invisível, já que

\footnotetext{
${ }^{84}$ Site consultado www.angra-dos-reis.com, acesso em agosto de 2007.
} 


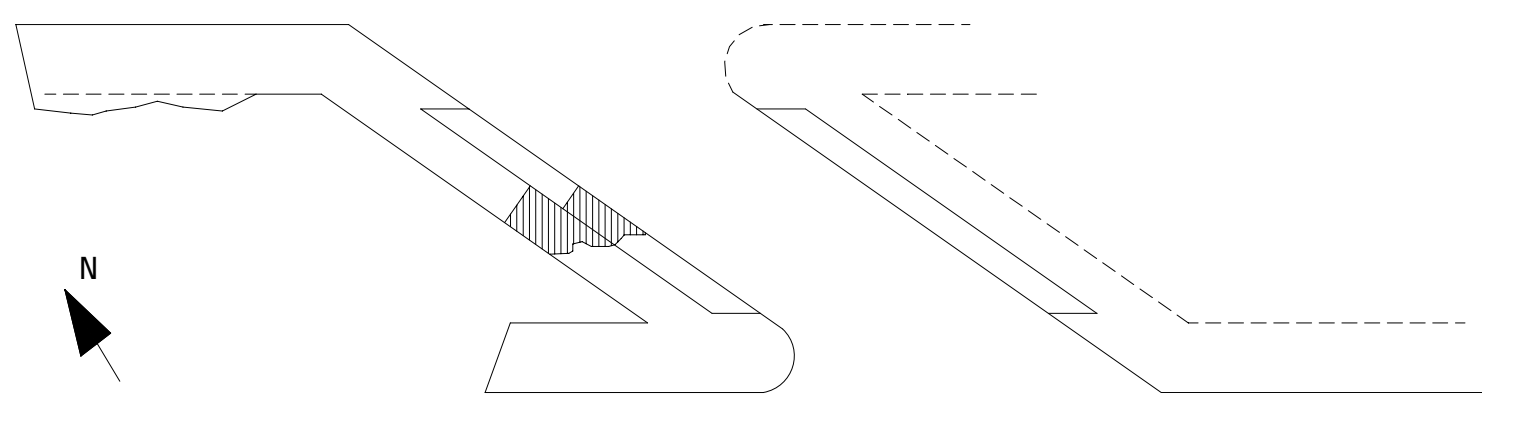

Figura 103 - Estrutura 3 (3.1, à esquerda e 3.2, à direita)

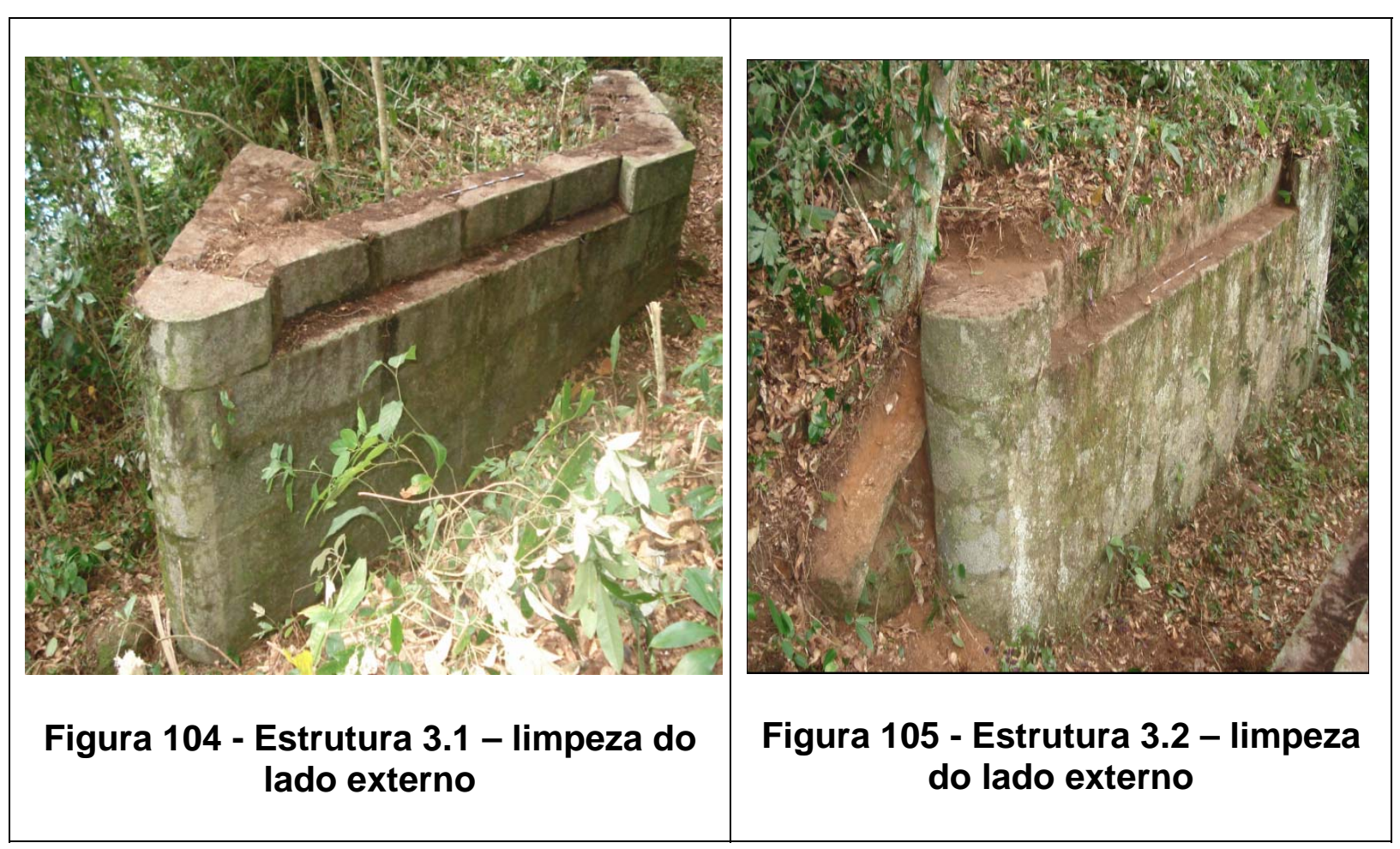




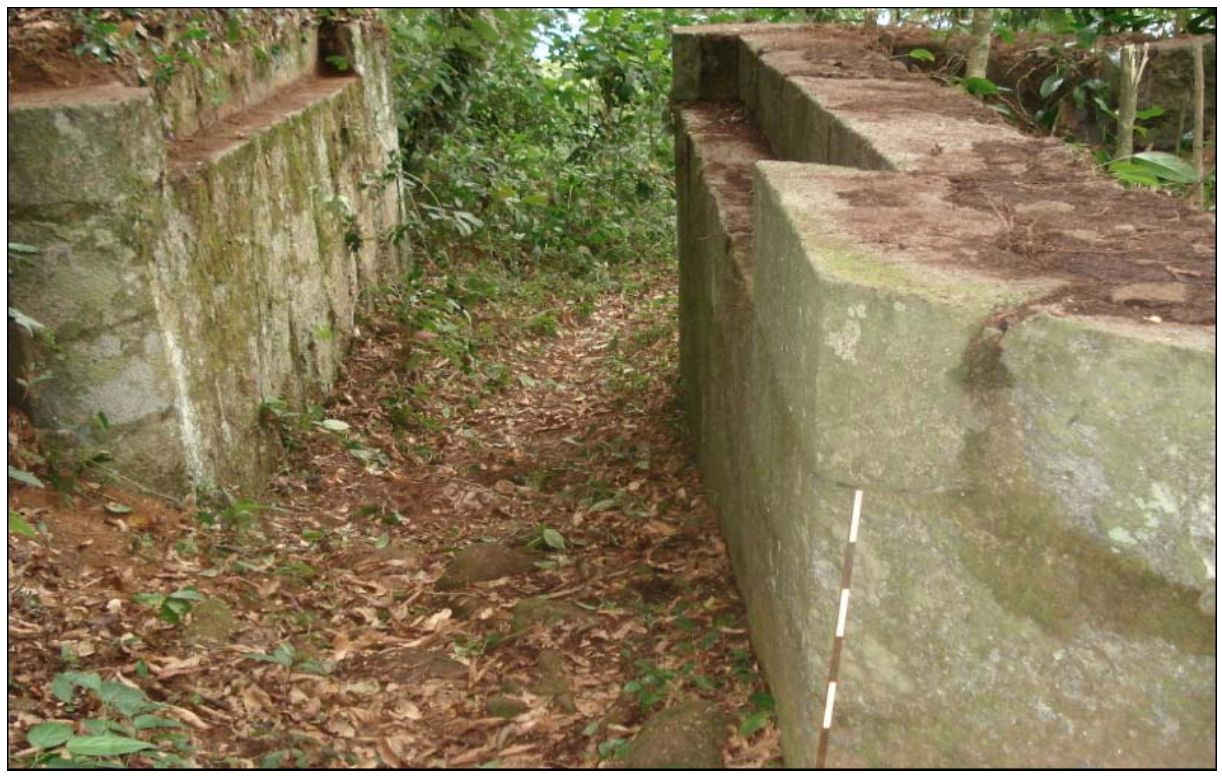

Figura 106 - Estruturas 3.1 (à direita) e 3.2 (à esquerda)

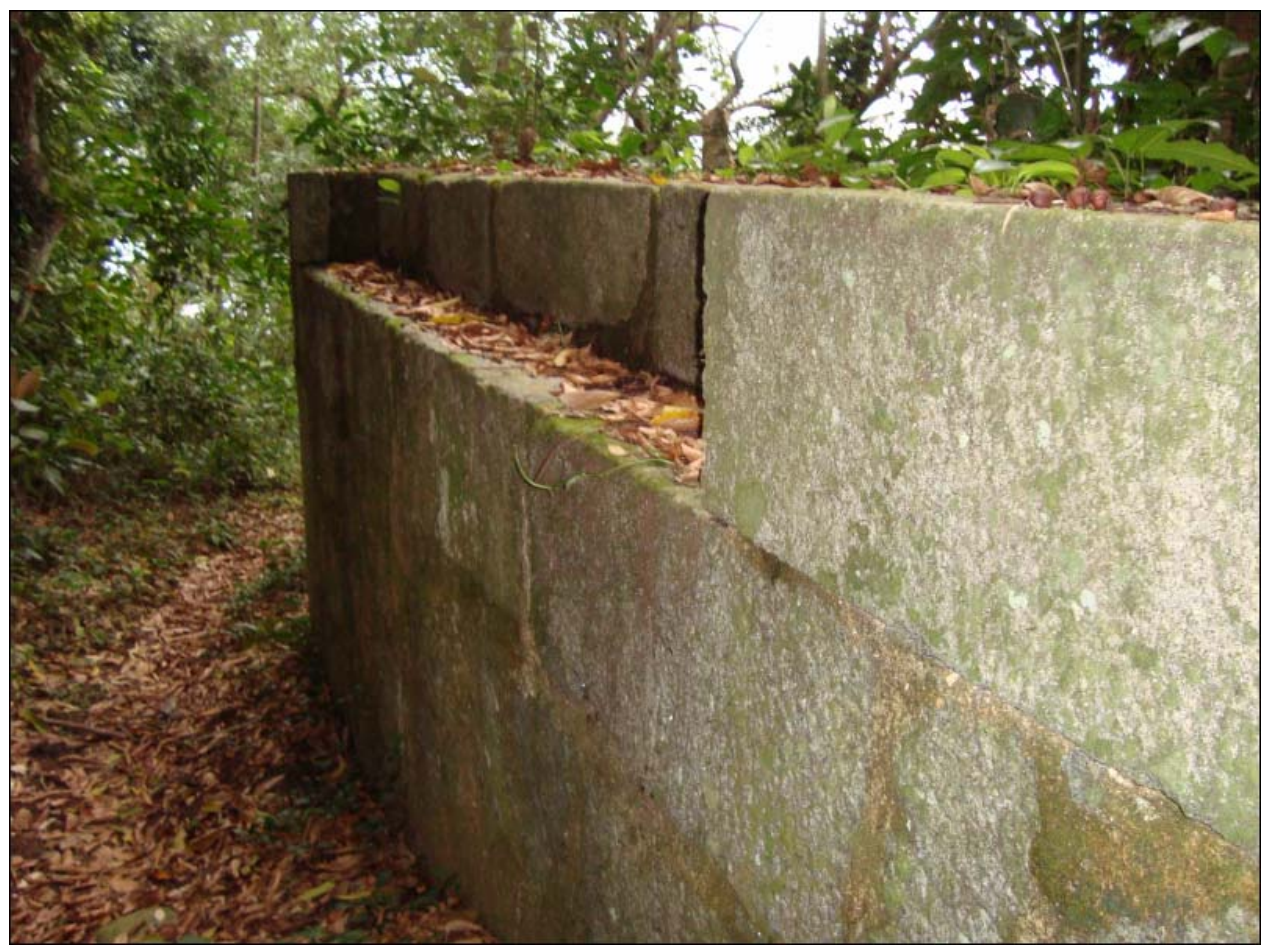

Figura 107 - Detalhe da estrutura 3.1 
uma das casas foi construída sobre a mesma. Para acessá-la foi preciso entrar em uma galeria por onde passa um riacho, que deságua no mar (figuras 110 e 111).

A estrutura da Praia do Coqueiro (figura 117) foi construída com a mesma técnica da estrutura 3 , ou seja, pedra cortada com argamassa. A mesma apresenta um formato quadrangular e, em seu centro, um arco, por onde passam as águas do riacho. Sua coordenada geográfica é a seguinte:

Estrutura Praia do Coqueiro

A informação oral mais uma vez reforçou que a mesma foi construída para fazer parte de um projeto de uma linha férrea que não foi concluído. Além disso, outras estruturas foram indicadas por moradores locais. A primeira delas seria um túnel dessa linha férrea, localizado num condomínio particular, local não visitado. A segunda, vestígios do que seria uma antiga ponte no distrito de Monsuaba, onde fizemos uma inspeção visual.

\section{Estrutura de Monsuaba}

A estrutura de Monsuaba também é conhecida por todos como pertencente à antiga linha férrea (ver figura 118). Ela fica próxima a uma cachoeira e apresenta pedras cortadas com argamassa. A mesma é formada por duas grandes colunas com, aproximadamente, $5 \mathrm{~m}$ de altura e $8 \mathrm{~m}$ de extensão (figuras 112 e 113). Em uma das partes (voltada para a cachoeira), as colunas se unem por uma parede, o que dá um aspecto quase quadrangular, em formato de "U".

É interessante ainda observar que suas colunas, na parte oposta a da cachoeira, não são unidas entre si, apresentam uma distância entre elas de 2 metros. Além disso, em determinados locais há a ausência de pedras, o que indica que foram retiradas ou, até mesmo, nem colocadas, algo que sugere o "abandono" desta construção. Cabe ainda destacar que atualmente a parte voltada para a cachoeira é aproveita como parede de uma casa construída junto à estrutura (figuras 114 e 115). Sua coordenada segue abaixo: 

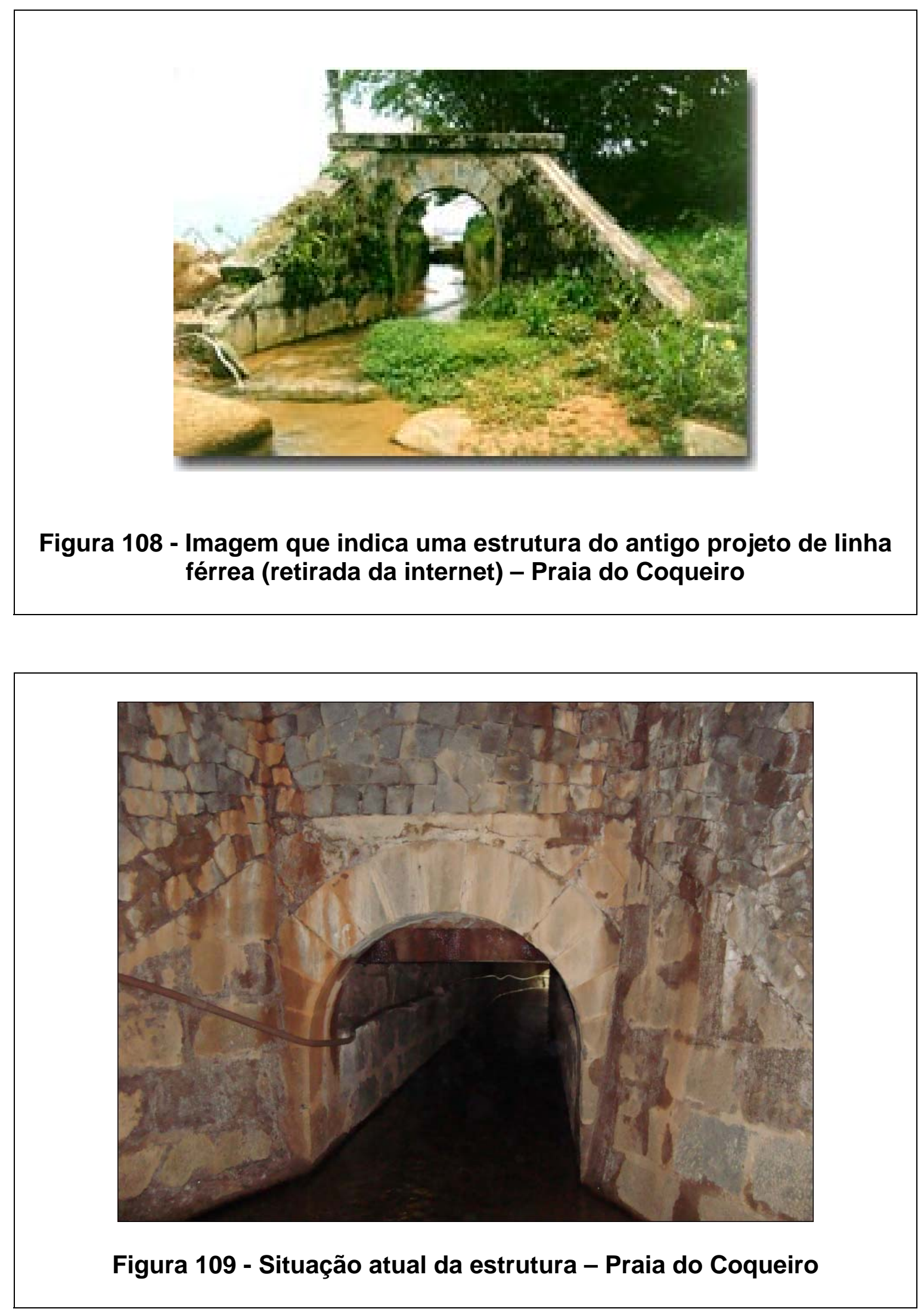


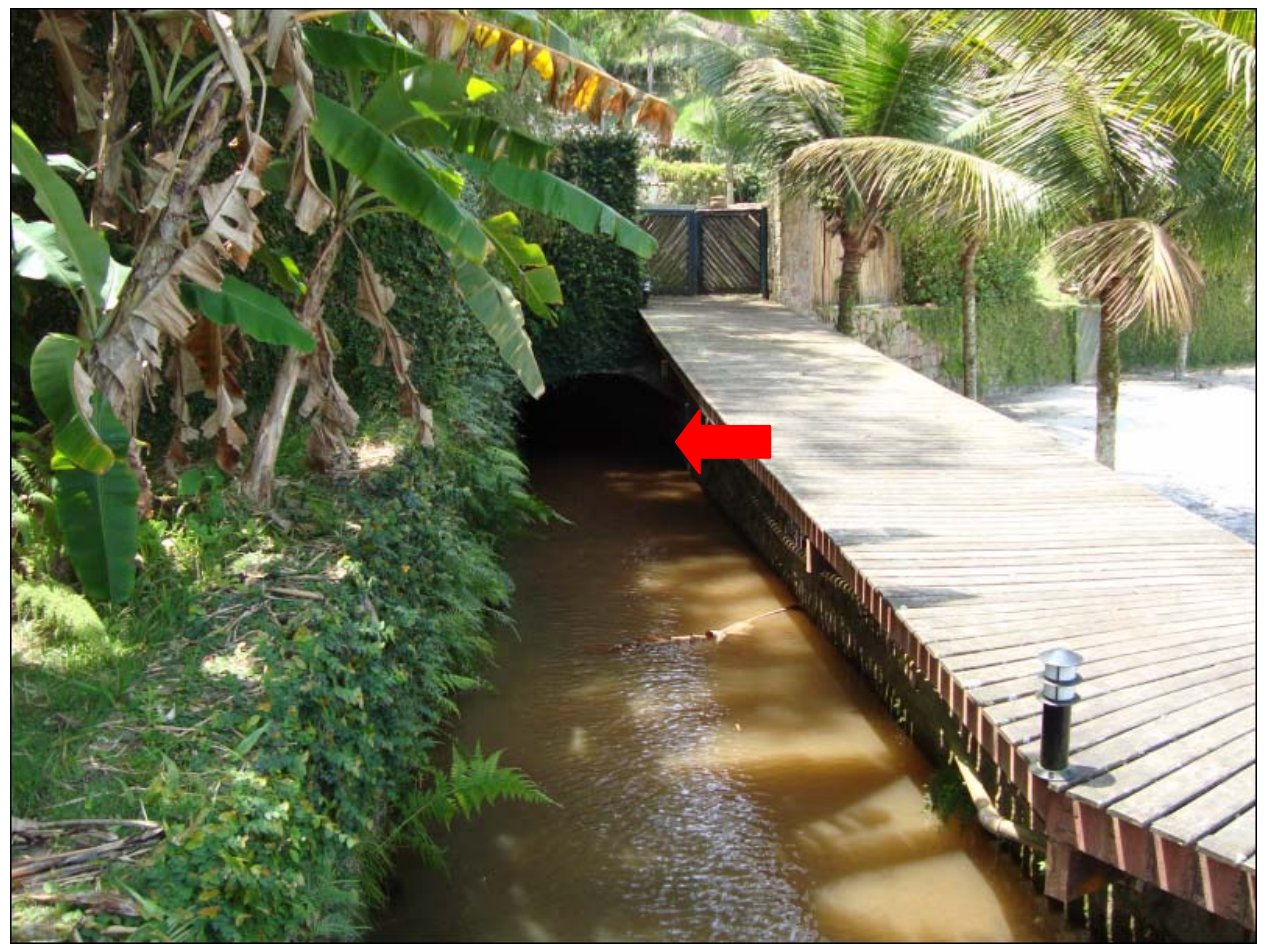

Figura 110 - Galeria de acesso à estrutura - Praia do Coqueiro

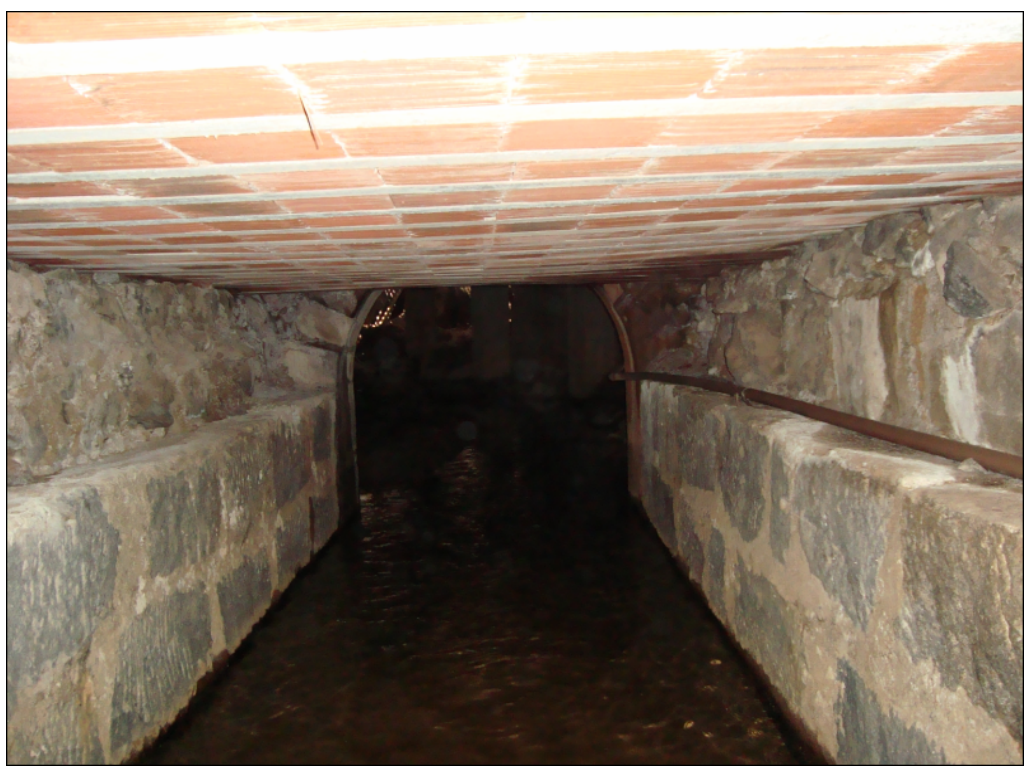

Figura 111 - Detalhe da parte interna da galeria 


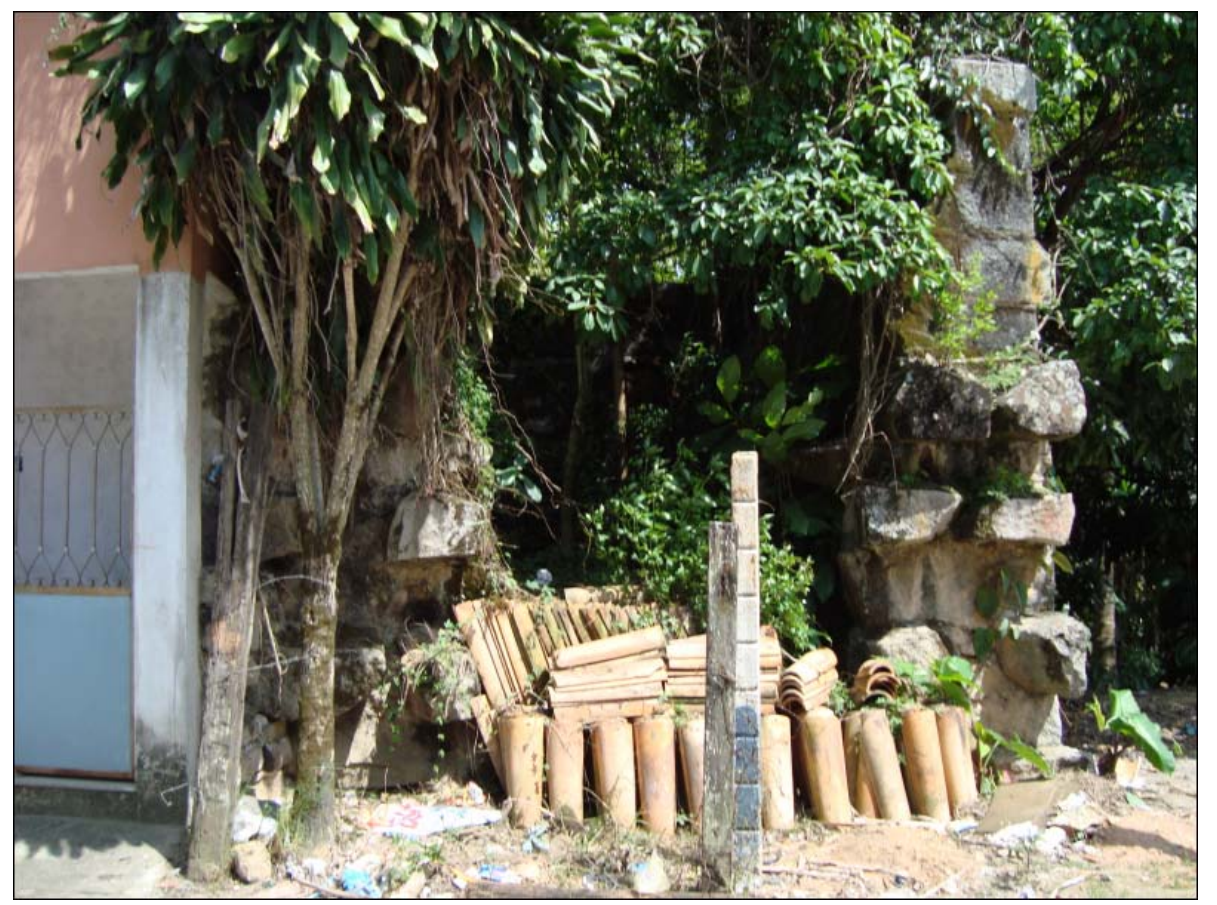

Figura 112 - Estrutura de pedra cortada - Cachoeira Monsuaba

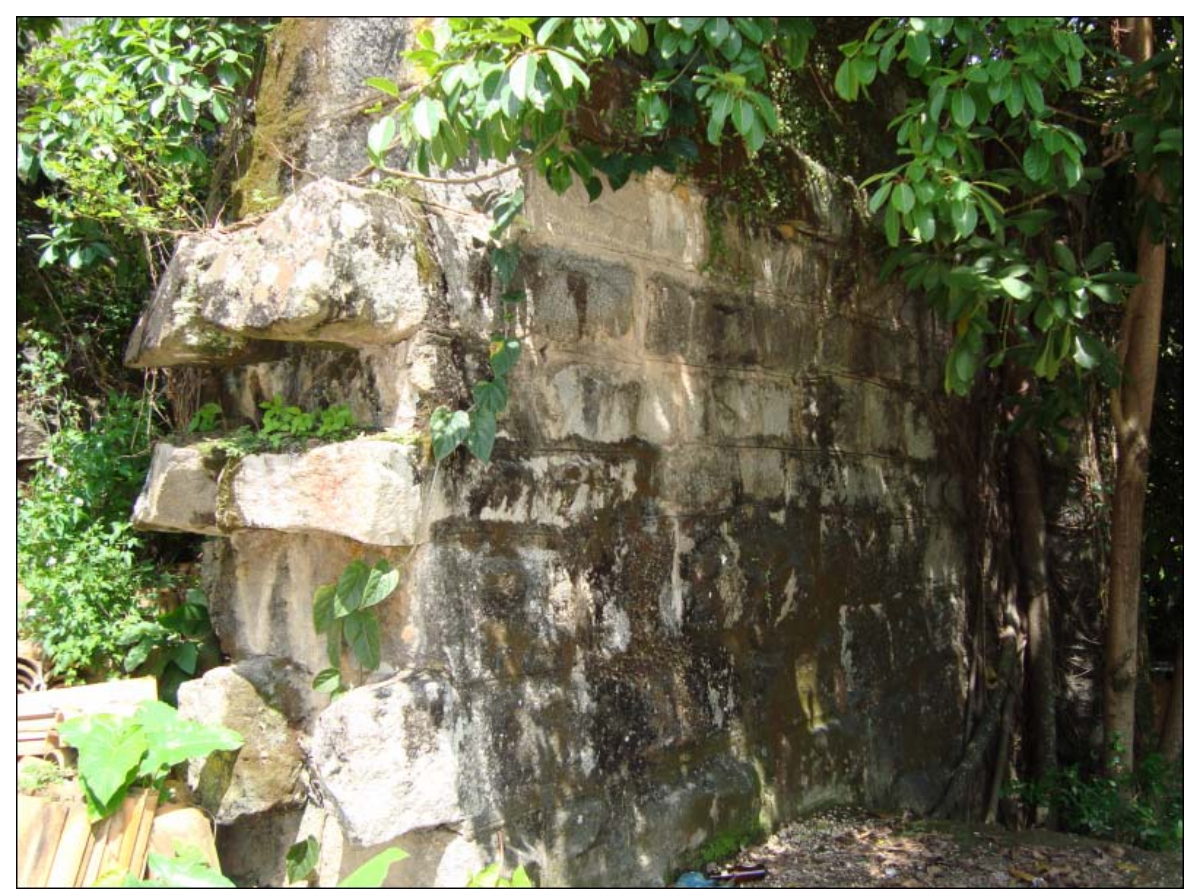

Figura 113 - Detalhe da estrutura de Monsuaba 


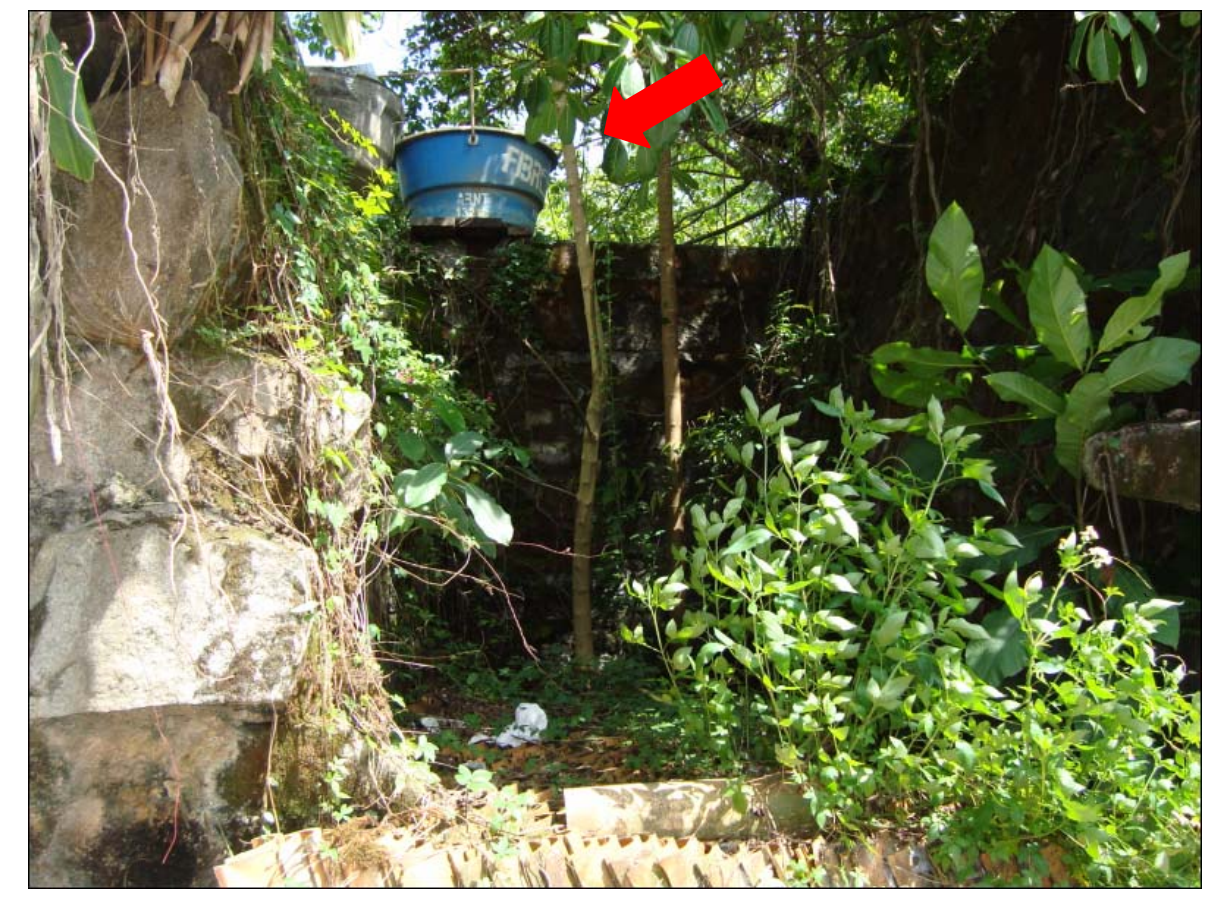

Figura 114 - Parede da estrutura de Monsuaba que serve de apoio para uma casa, construída logo atrás

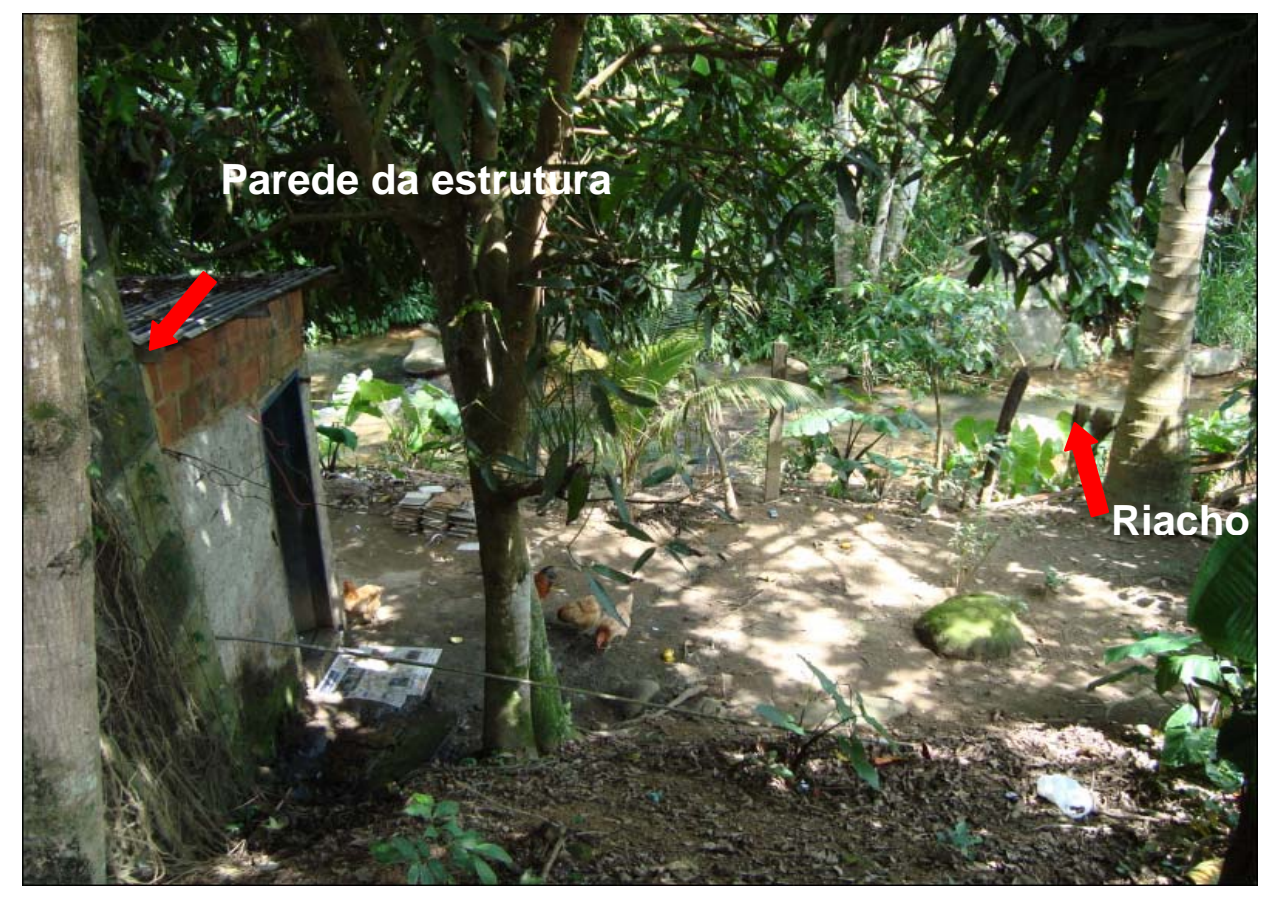

Figura 115 - Detalhe da casa e do riacho (cachoeira) 


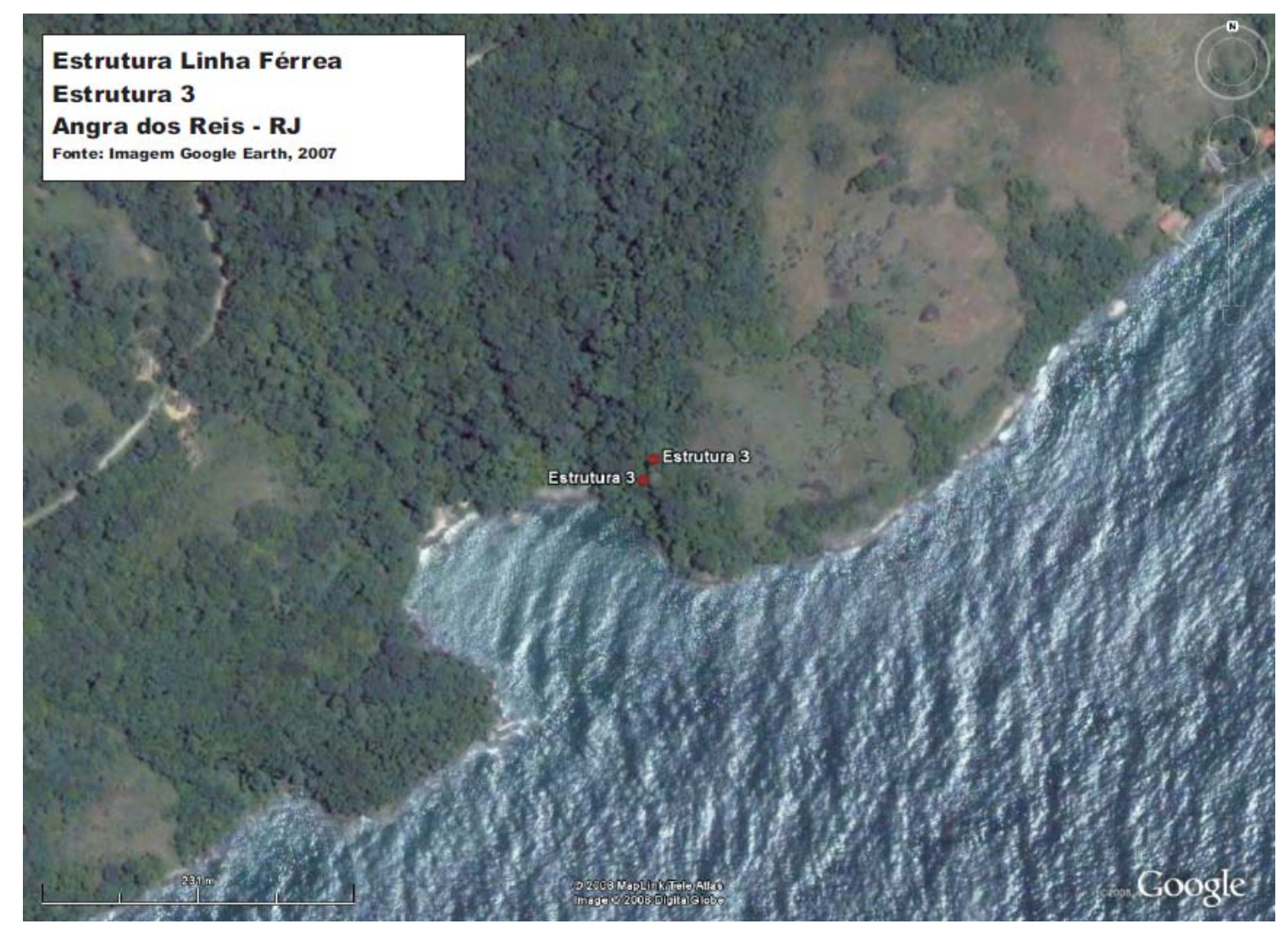

Figura 116 - Estrutura 3 


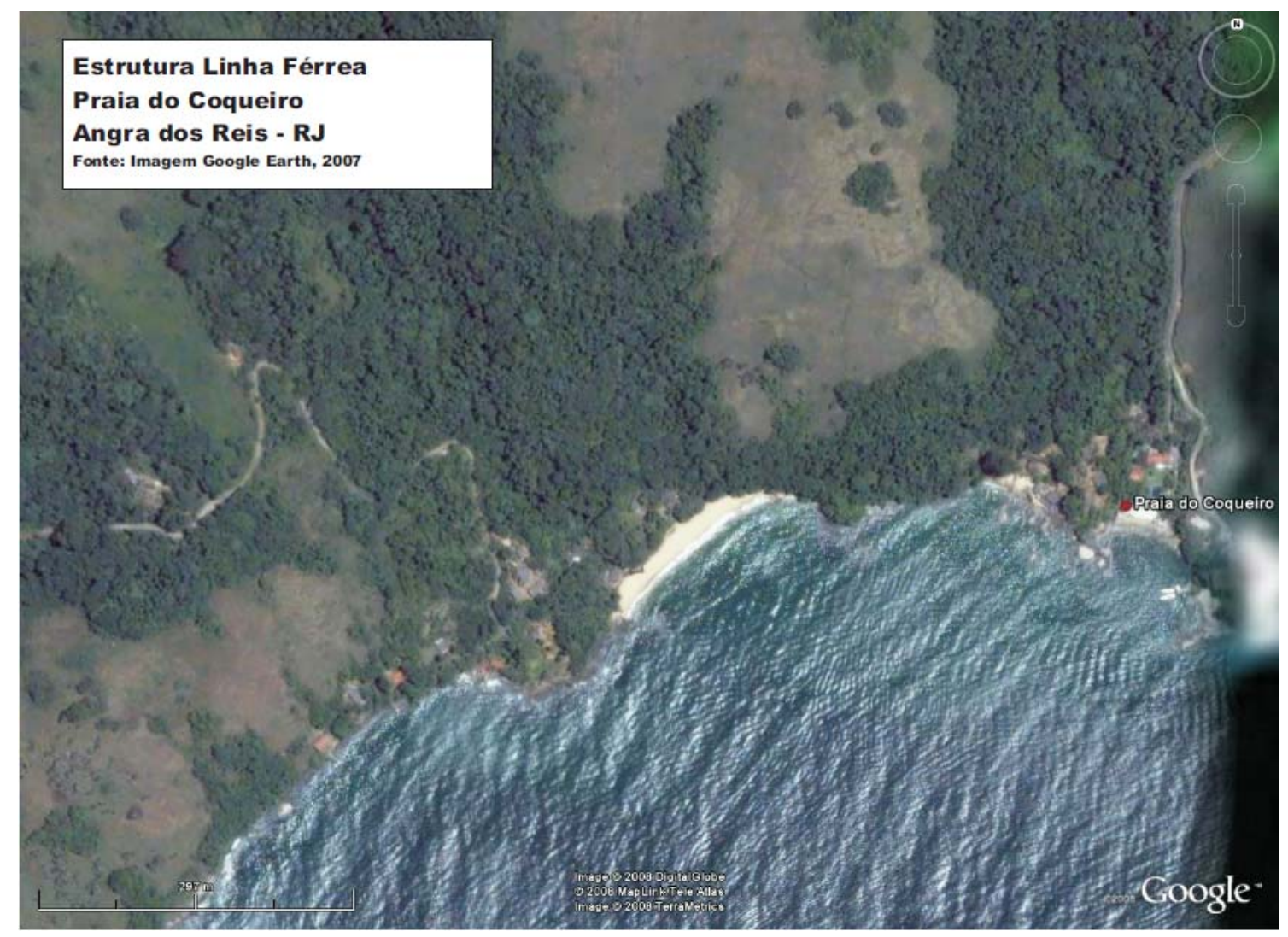

Figura 117 - Praia do Coqueiro 


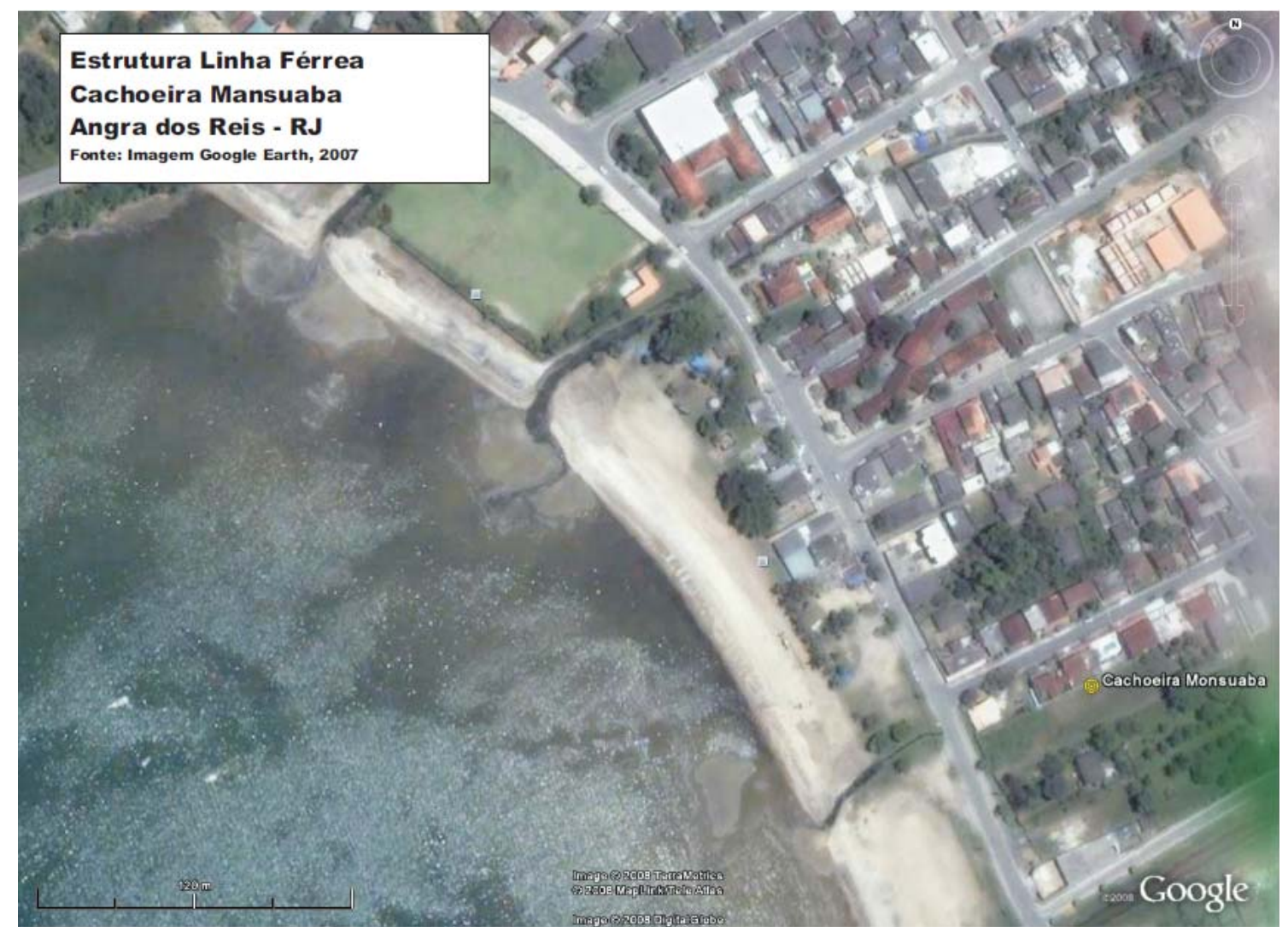

Figura 118 - Estrutura Cachoeira Monsuaba 
Como dito, pouco podemos dizer sobre a construção de uma linha férrea na região, projeto este que foi abandonado, conforme informações orais. Para mais considerações serão necessários estudos mais detalhados. Apenas indicamos que a estrutura da Praia do Coqueiro e a de Monsuaba, além da técnica de pedra cortada, foram implantadas em áreas próximas à água doce. Em comparação com as demais estruturas apresentadas, desde sua implantação até a técnica construtiva, em nada se parecem com as que consideramos defensivas e estratégicas, principalmente porque não estão em locais que apresentam visibilidade direta com o mar.

Retomando a área da Ponta Leste, é importante acrescentar que foram realizados levantamentos sistemáticos de superfície em locais mais elevados da Ponta do Leme, também na Ponta do Pasto, onde fica o Píer da Petrobrás e na Ponta de Leste, onde está o monumento do Aquidabã e na Praia dos Maciéis. Em todos estes locais não foram identificadas estruturas de pedra relacionadas aos contextos históricos apresentados (figuras 119 a 127). Segue abaixo as coordenadas geográficas:

\begin{tabular}{|l|l|}
\hline Ponta do Leme & $\mathrm{S} 23^{\circ} 03^{\prime} 12^{\prime \prime} / \mathrm{W} 44^{\circ} 13^{\prime} 53,3^{\prime \prime}$ \\
\hline Ponta do Leme & $\mathrm{S} 23^{\circ} 03^{\prime} 09,8^{\prime \prime} / \mathrm{W} 44^{\circ} 13^{\prime} 47,4^{\prime \prime}$ \\
\hline Ponta do Leme & $\mathrm{S} 23^{\circ} 03^{\prime} 06,9^{\prime \prime} / \mathrm{W} 44^{\circ} 13^{\prime} 52,6^{\prime \prime}$ \\
\hline Píer Petrobrás & $\mathrm{S} 23^{\circ} 03^{\prime} 08,4^{\prime \prime} / \mathrm{W} 44^{\circ} 14^{\prime} 26^{\prime \prime}$ \\
\hline Aquidabã & $\mathrm{S} 23^{\circ} 02^{\prime} 50,7^{\prime \prime} / \mathrm{W} 44^{\circ} 14^{\prime} 53,7^{\prime \prime}$ \\
\hline Praia dos Maciéis & $\mathrm{S} 23^{\circ} 02^{\prime} 55,8^{\prime \prime} / \mathrm{W} 44^{\circ} 13^{\prime} 27^{\prime \prime}$ \\
\hline
\end{tabular}




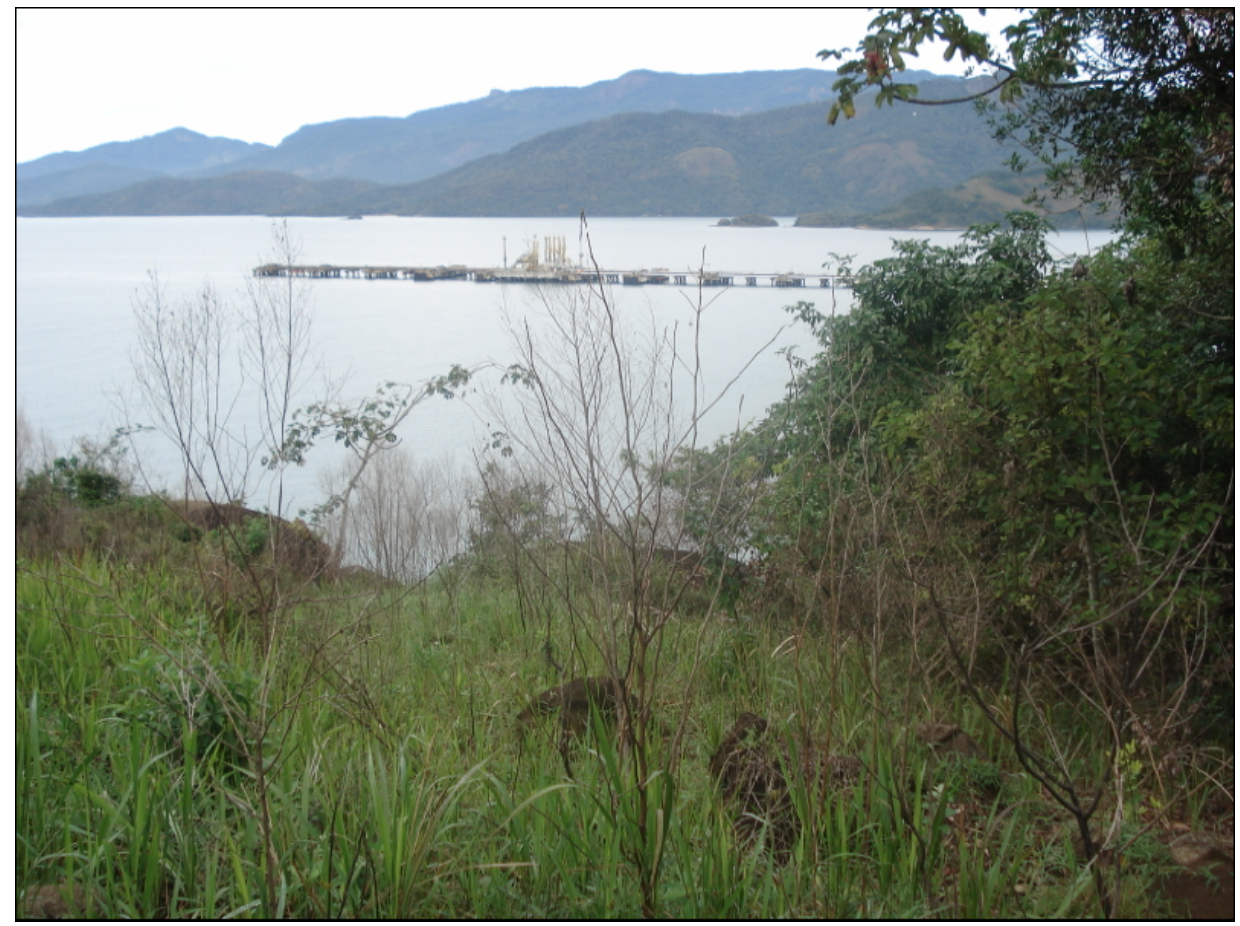

Figura 119 - Área prospectada próxima ao Forte do Leme (Ponta do Leme)

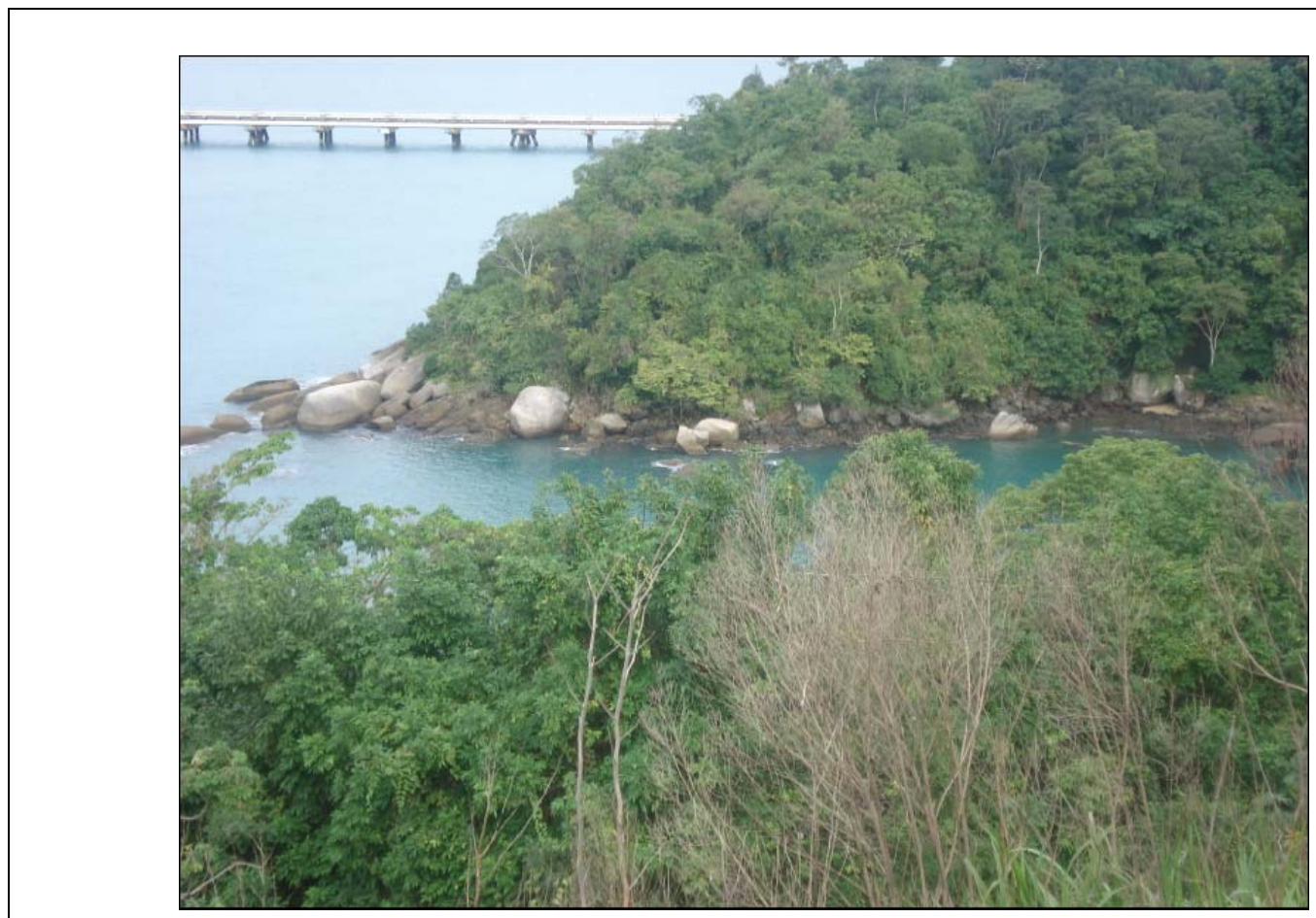

Figura 120 - Área prospectada em nível mais elevado (Ponta do Leme) 


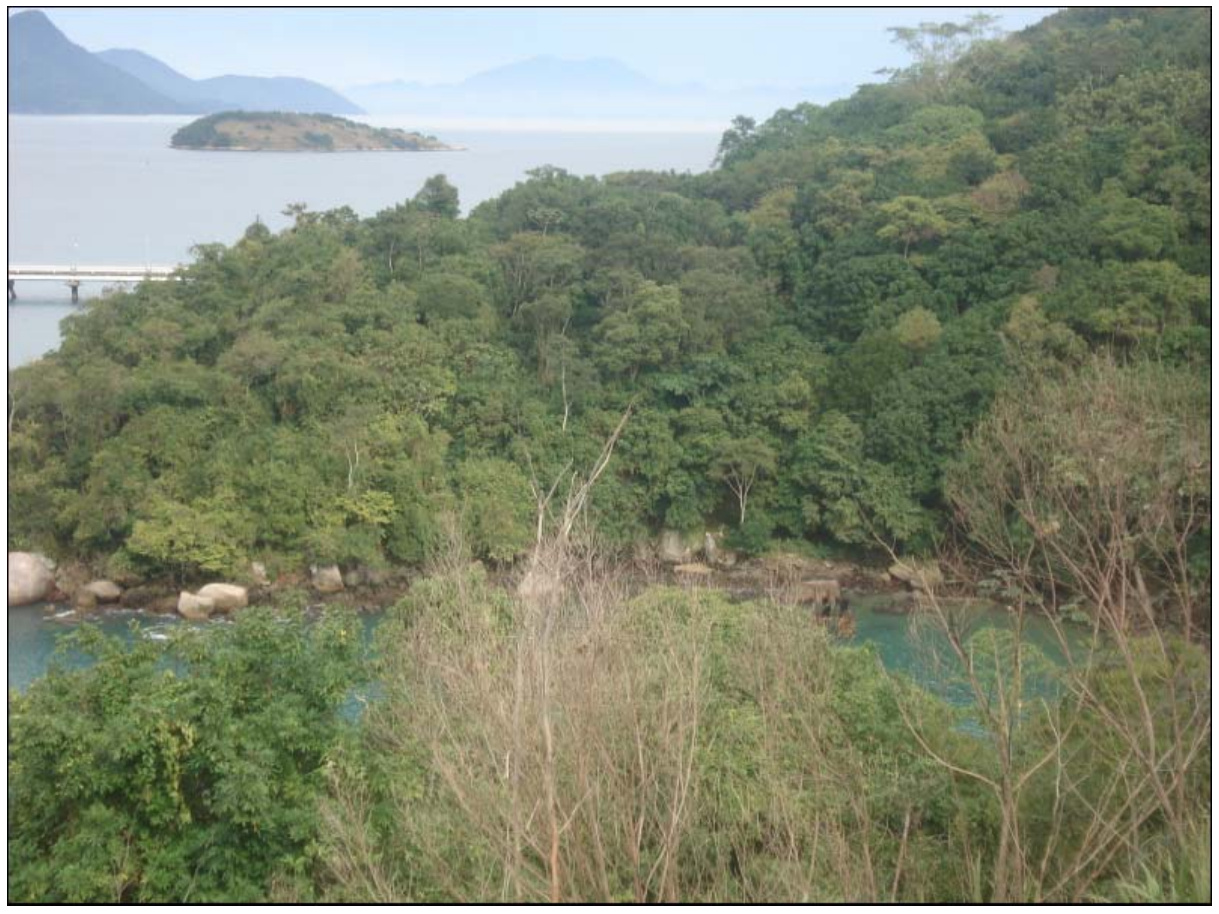

Figura 121 - Área prospectada - ao fundo Ilha dos Macacos e Ilha Grande (Ponta do Leme)

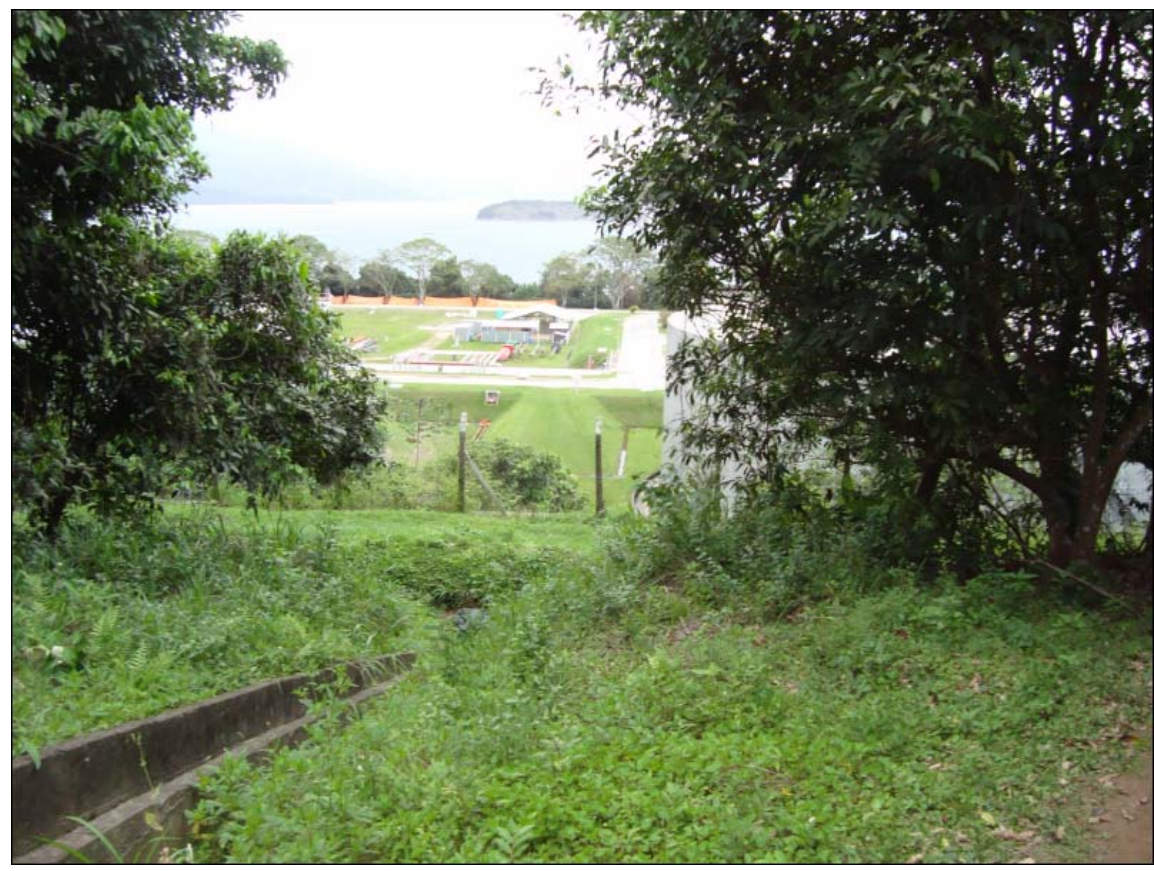

Figura 122 - Área prospectada - Ponta do Pasto (píer da Petrobrás) 


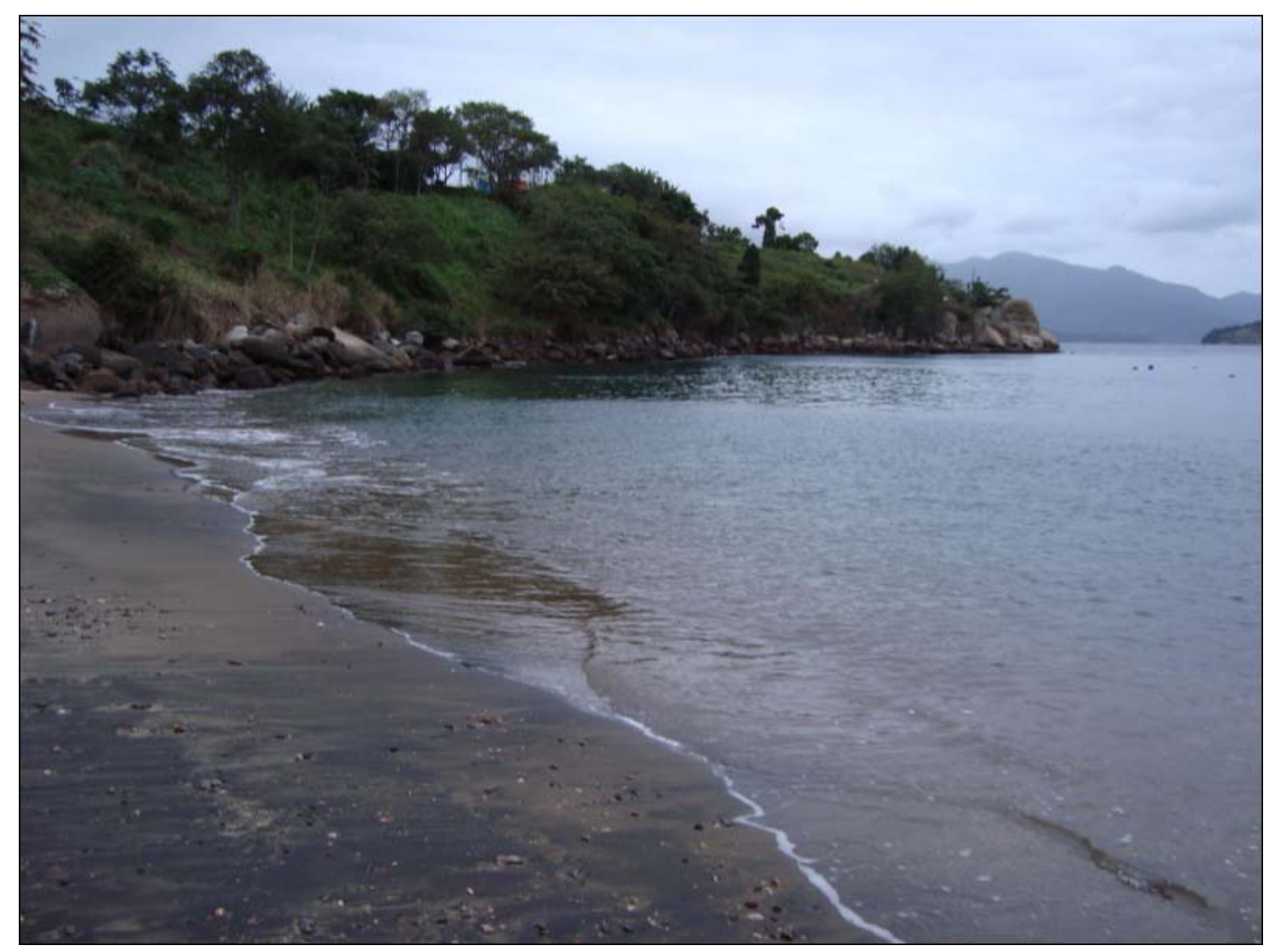

Figura 123 - Praia na Ponta do Pasto - sem estruturas

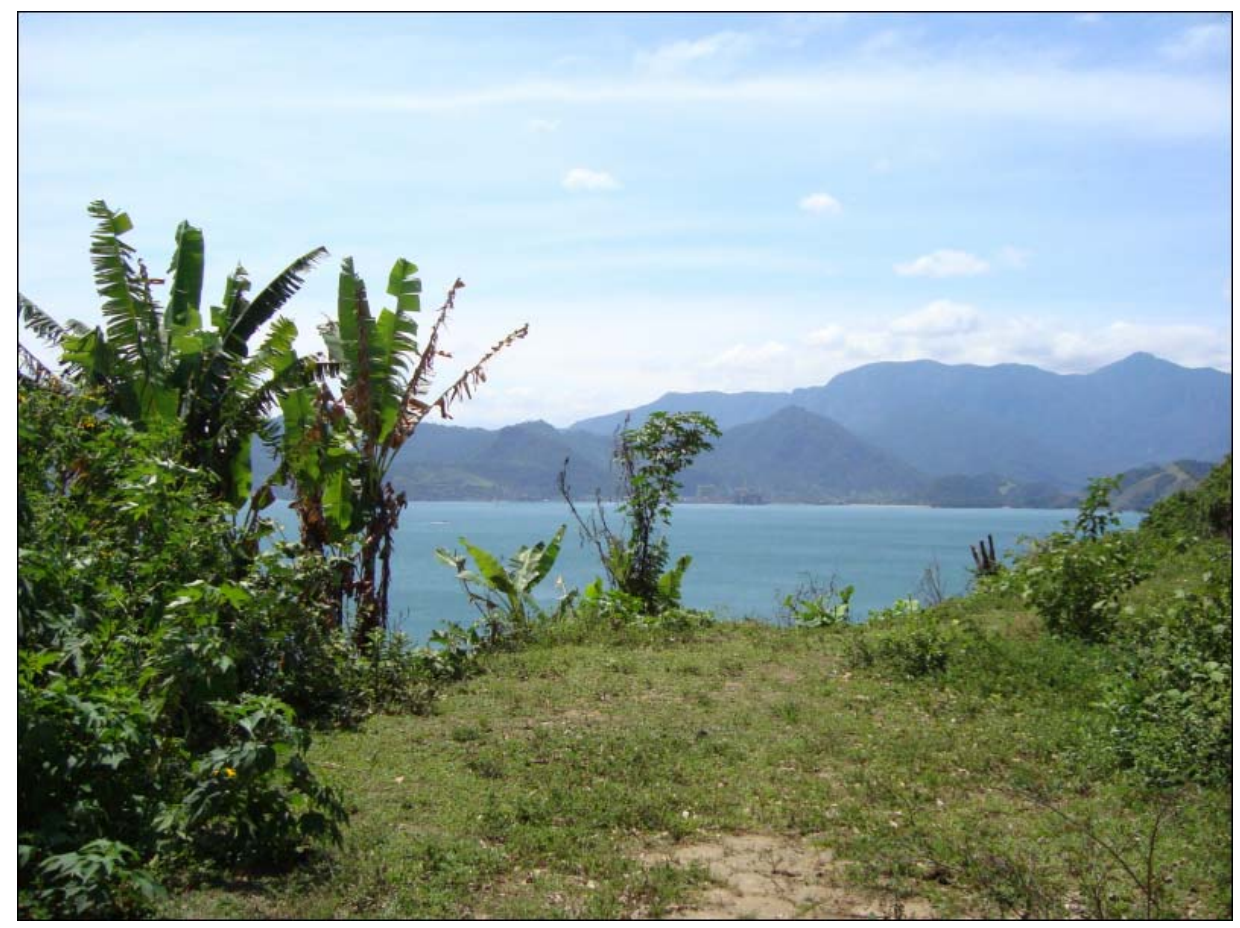

Figura 124 - Ponta Leste - Aquidabã - sem estruturas 


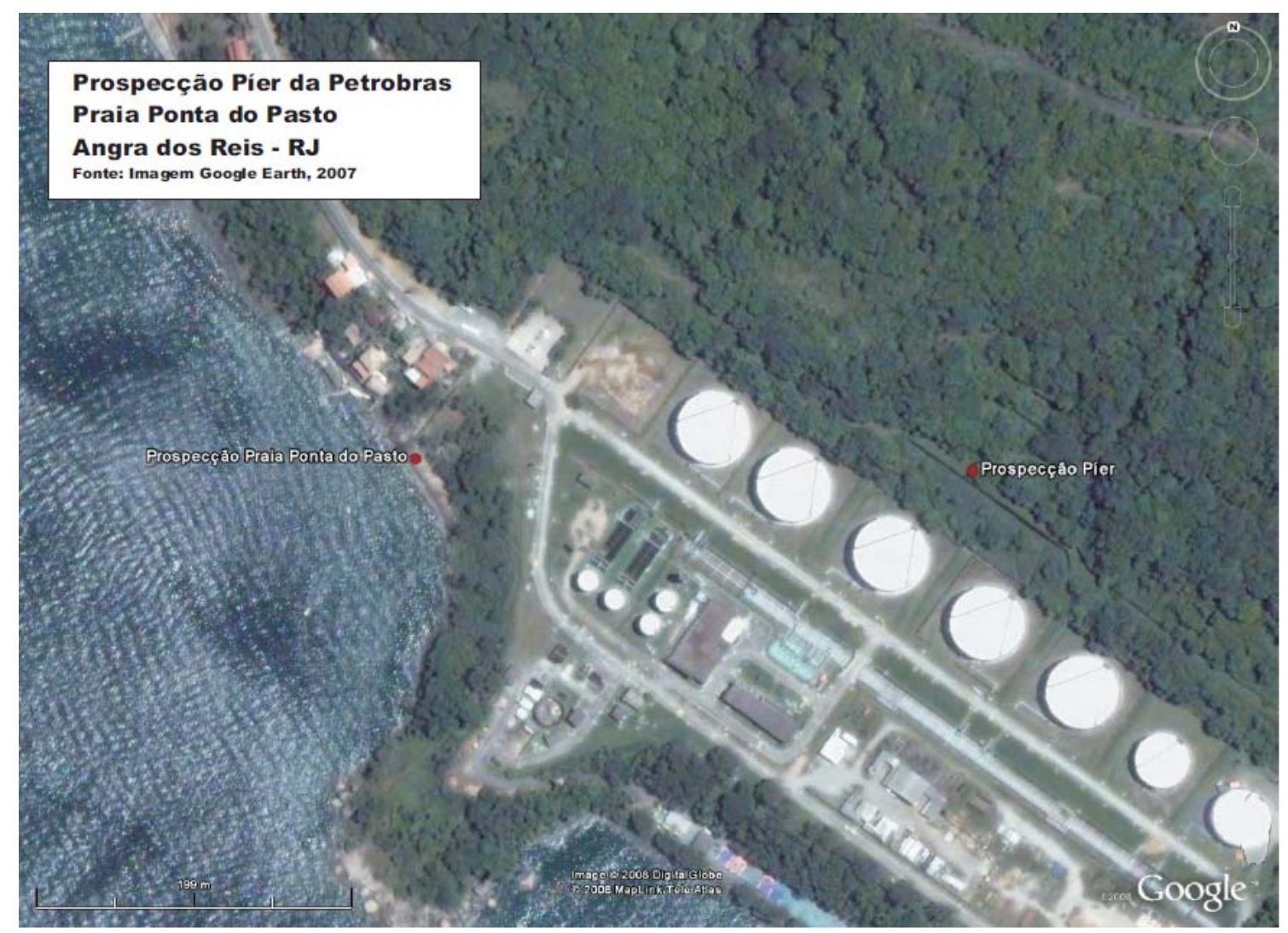

Figura 125 - Prospecção Píer e Ponta do Pasto 


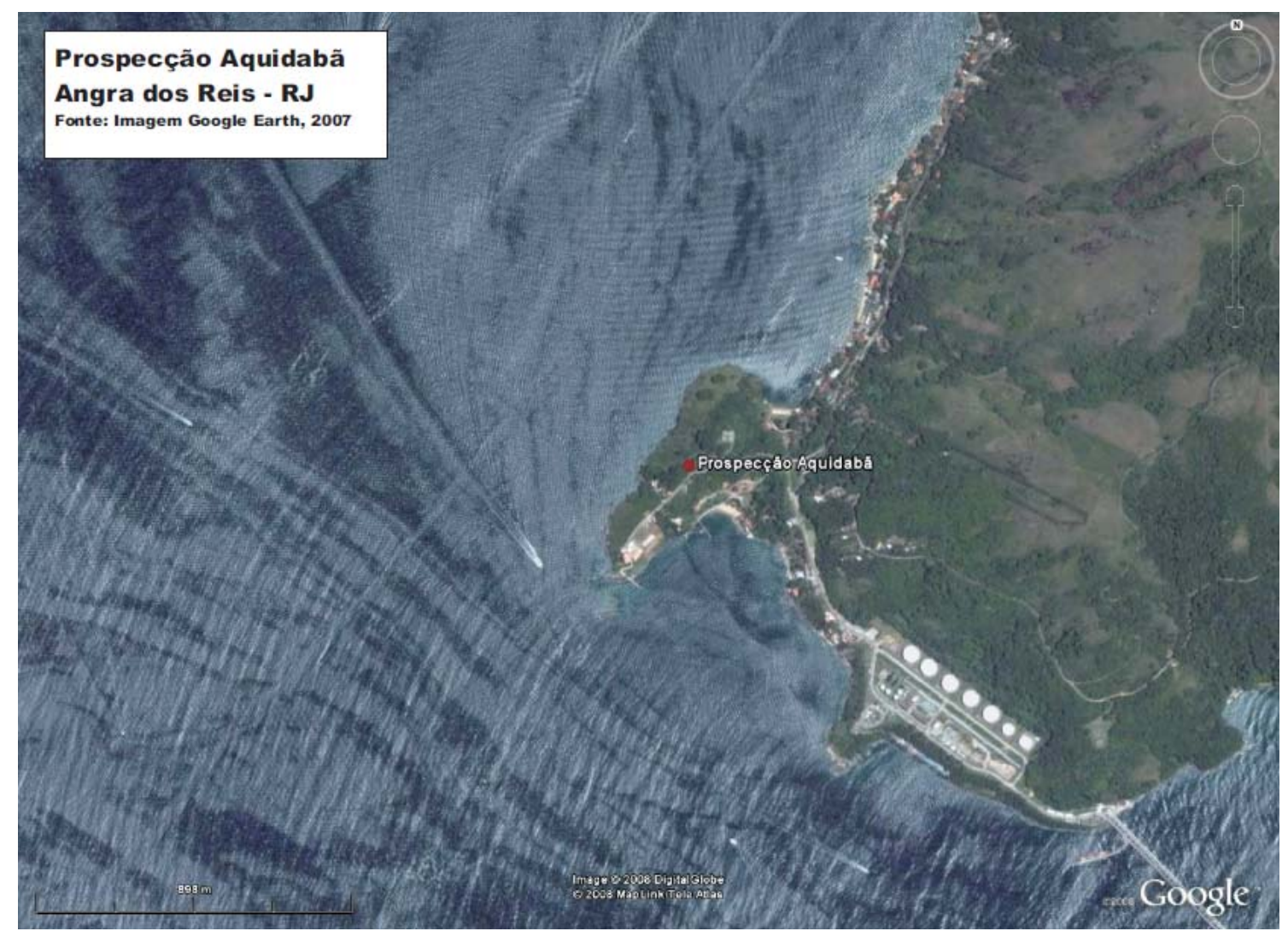

Figura 126 - Prospecção Aquidabã 


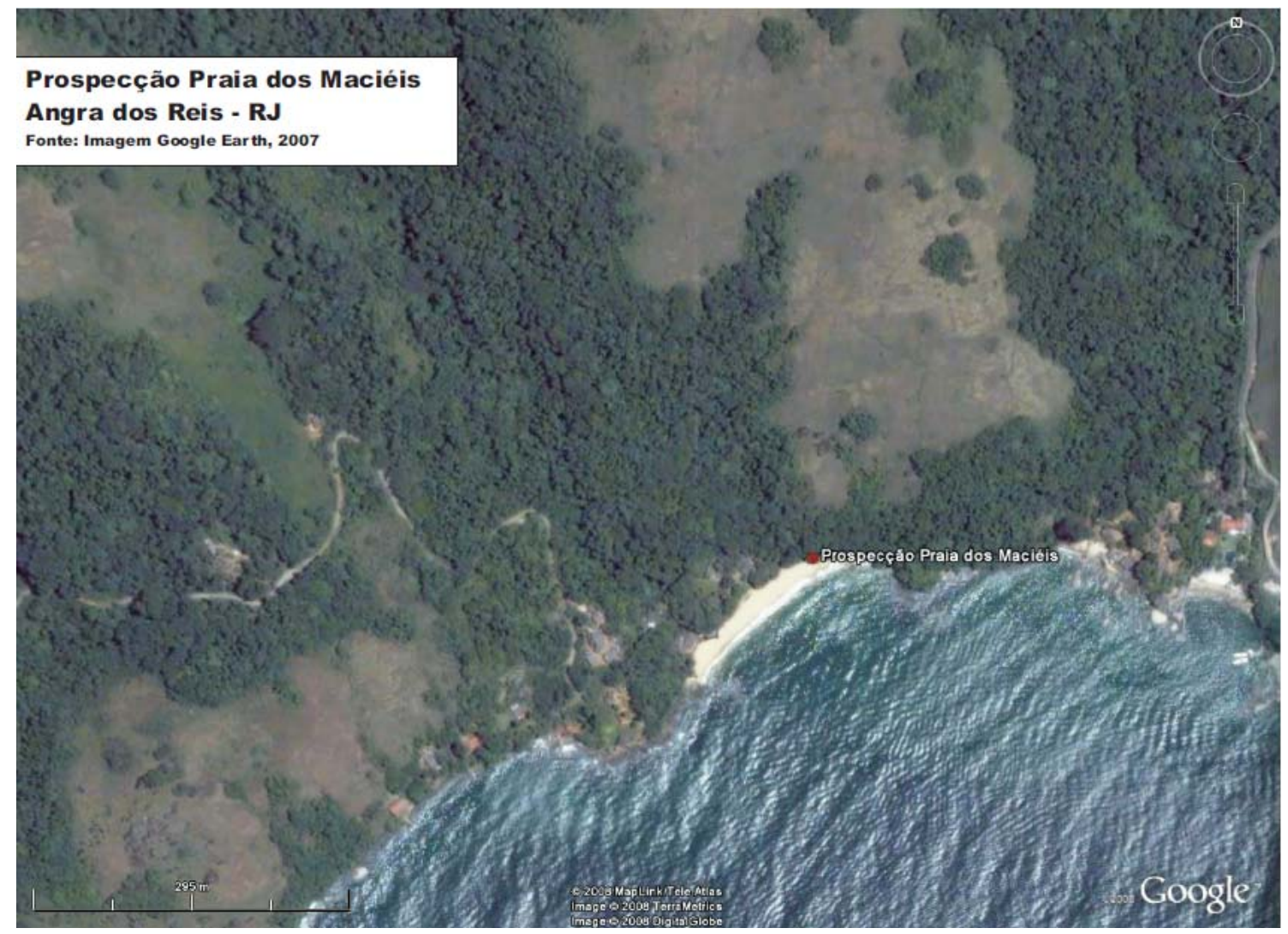

Figura 127 - Prospecção Praia dos Maciéis 


\section{Evidências defensivas na Ponta Leste}

As estruturas 1, 2 e 4, pela sua altura e extensão aproximada, parecemse com muros. Na parte mais alta destas estruturas, as sondagens realizadas, com exceção da estrutura 4, permitiram verificar a presença de pedras menores, que podem indicar um piso. Estas estruturas, pela sua disposição, parecem ter relação entre si, já que se encontram em frente um dos outros e foram feitas com a mesma técnica construtiva. As estruturas 1 e 2 são bem próximas, a uma distância de $11,30 \mathrm{~m}$. A primeira está voltada para a Ilha Grande e para a enseada onde está localizada e a segunda, já que respeita o contorno do morro onde foi construída, tem uma parte que se volta para a Ilha Grande, porém, o seu término está voltado para o lado oposto, ou seja, a Ilha da Marambaia. A estrutura 4 está, definitivamente, em frente a 1, porém, em nível mais alto, ou seja, a $20 \mathrm{~m}$ de altitude, do outro lado da enseada.

Ainda sobre a disposição destas estruturas, as coordenadas geográficas indicam que a localização não permite visada para o porto de Angra dos Reis, porém, as mesmas estão posicionadas, como dito, para a Ilha Grande. Entretanto, não estar voltado para o porto da cidade de Angra dos Reis não significa que estas estruturas não participaram de um sistema defensivo, visto que as mesmas poderiam evitar desembarque nesta enseada e sinalizar para a Ilha Grande quando fosse identificada a presença de navios estrangeiros na região. Vale ainda destacar que no século XIX a sede do governador militar de Angra dos Reis era localizada em Santana da Ilha Grande, ou seja, próximo à enseada onde estão estas estruturas.

A proximidade com mar pode ter sido um elemento facilitador no transporte das peças de artilharia, não sendo necessários, nesse sentido, caminhos ou trilhas que levassem essas peças, já que as mesmas poderiam ser levadas por barcos e descarregadas na própria enseada onde se encontram. As peças de artilharia usadas podem ter sido semelhantes às que estão localizadas na cidade de Angra dos Reis e que foram descritas neste trabalho. Neste caso, as mesmas possuem um alcance médio de $2 \mathrm{~km}$, com pouca precisão e poder destrutivo, o que não destruiria um navio estrangeiro, 
mas seria suficiente para retardar seu avanço e ainda serviria como alarde para outras regiões também guarnecidas. 
CONCLUSÃO 
Percebemos que no litoral sul fluminense, desde o século XVI, a ameaça de invasão estrangeira foi constante. Entre os séculos XVII e XVIII, o contrabando de ouro e de escravos, sempre tão comuns na região, aumentou ainda mais o risco de invasão. Nesse sentido, Itaguaí, Sepetiba, Ilha Grande, Angra dos Reis e Paraty eram vilas que exigiram constantes esforços da população local e das autoridades da cidade do Rio de Janeiro para sua defesa.

Assim, o objetivo primordial desta pesquisa foi identificar a existência de estruturas defensivas e outros elementos na região de Angra dos Reis que indicassem e comprovassem ações que, de alguma forma, protegeram o litoral sul fluminense e a cidade do Rio de Janeiro do corrente risco de invasão. (figura 128) Esses elementos foram vários: a toponímia local, os canhões dispostos em Angra dos Reis, as fontes iconográficas, as cartas, ofícios e relatórios defensivos, cujo conteúdo não podemos afirmar a veracidade, mas é possível, ao menos, propor uma constante preocupação das autoridades da época por conta da presença de corsários e piratas, do contrabando de escravo e de ouro etc.

As próprias estruturas defensivas encontradas ofereceram informações: os padrões construtivos inseridos na paisagem litorânea, isto é, a matériaprima, a forma, a disposição no terreno, a relação de cada uma com as demais e a excelente visibilidade. Todos esses são fatores que, somados a uma análise que privilegia as diferentes fontes, nos leva a considerações mais precisas sobre as estratégias de defesa.

Ao que tudo indica, os padrões construtivos são semelhantes aos encontrados no litoral norte de São Paulo, pesquisado por CAMARGO (2002). Como dito no início desta pesquisa, essas obras defensivas eram trincheiras, fortins, redutos, fortes, construídos da noite para o dia, num momento necessário, ou seja, embora muitas vezes planejadas, só teriam sido executadas em situações de máxima tensão. Soma-se a isso o fato de serem reforçadas por faxina e, até mesmo, barreiras de cestos cheios de pedra, areia e entulho, o que significa que muitas das informações materiais não foram preservadas. Assim, estas estruturas tinham um caráter provisório, porque não 
eram finalizadas e nem eram grandes obras defensivas, compostas por paiol, quartel, casa de pólvora e outras construções.

No que diz respeito à cidade de Angra dos Reis, esta também apresenta elementos que comprovam a aplicação de estratégias defensivas. No período colonial, a cidade contou com dois fortes: o Forte do Carmo e de o São Bento, construídos no século XVIII provavelmente. Outras fortificações citadas pela historiografia local, a da Ponta da Cidade e a da Ilha do Barros, podem nem ter sido construídas, talvez por falta de pessoas ou também por falta de armamento, já que as fontes documentais indicam poucas peças de artilharia disponíveis na região.

Ainda devemos destacar que a defesa da antiga vila de Angra dos Reis, conforme a indicação das fontes escritas, contou com outro tipo de fortificação não permanente, como é o caso do entrincheiramento citado nos relatórios defensivos da cidade. No geral, as fortificações de Angra dos Reis parecem ter sido obras simples de defesa, com a presença de baterias. Entretanto, diferente de Piraquara e Ponta Leste, essas construções eram permanentes, pois as fontes documentais e iconográficas, sobretudo as do Forte do Carmo, indicam a existência de quartel e casa de pólvora, construções que já indicam uma fortificação completa e não apenas um conjunto de baterias dispostas em posições estratégicas.

No que diz respeito às peças de artilharia, os próprios canhões e as fontes escritas indicam uma defesa formada por armas de pouco calibre. Eram comuns peças de calibre 6,9 ou 12, com pouco alcance e poder destrutivo. Em Angra dos Reis foram identificados canhões ingleses, sendo a maior parte deles de calibre 12. O padrão Armstrong, trazido para o Brasil especialmente nas primeiras décadas do século XIX, já era considerado ultrapassado para a época. As características principais das peças restantes, cujos padrões não foram apontados, indicam que as mesmas são anteriores ao padrão Armstrong. Entretanto, são necessários estudos mais específicos sobre a artilharia de Angra dos Reis. Todas essas peças, que um dia pertenceram às fortificações da cidade, hoje estão descontextualizadas e não passam pelas vistorias e cuidados necessários, conforme informações orais. 
Faz-se necessário acrescentar que os fortes angrenses podem ter sido reforçados pela defesa implantada em Piraquara, isto é, pelas baterias, retaguardas e pontos de observação. Tais estruturas, algumas delas armadas com canhões, intimidavam a circulação de pessoas na área e o acesso à Angra dos Reis e, principalmente, ao Rio de Janeiro. Além disso, o tráfico de escravos e o contrabando do ouro poderiam ser consideravelmente diminuídos caso houvesse a guarda nas enseadas de fácil acesso.

O mesmo padrão de distribuição das baterias de Piraquara foi verificado na Ponta Leste, no lado oposto (local que apresenta maior profundidade da Baía da Ilha Grande). Nesta área, as estruturas de pedra seca encontram-se próximas ao mar e permitem excelente visibilidade para a Ilha Grande e, até mesmo, para a Ilha da Marambaia. Entretanto, não foram encontradas construções em níveis elevados que indicam pontos de observação do litoral, talvez pela construção do Forte do Leme, que resultou na alteração da paisagem natural da área.

A disposição de todas as estruturas identificadas em Piraquara indica que, além de haver construções voltadas para a Vila de Paraty, haviam estruturas voltadas para a Ilha da Gipóia e para Angra dos Reis. O mesmo não acontece com a Ponta Leste, que apresentou baterias que permitem excelente visibilidade para a Marambaia e, principalmente, para a Ilha Grande, como mencionado.

Essas "paisagens defensivas", Piraquara, Angra dos Reis e Ponta Leste, apresentam estruturas com a mesma técnica construtiva. Além disso, a forma de implantação no terreno em locais de excelente visilibilade e, ao mesmo tempo, discretas na paisagem, é muito parecida: estruturas próximas ao mar e logo acima, com $20 \mathrm{~m}$ de altitude, aproximadamente. Embora poucos documentos específicos sobre Piraquara e Ponta Leste tenham sido localizados, a toponímia local apresenta um indicador de ocupação estratégica, pois as três localidades possuem nomes ligados à palavra Fortaleza: em Piraquara, Ponta da Fortaleza, em Angra dos Reis e na Ponta Leste, Morro da Fortaleza.

Em relação ao Forte do Leme, sua construção esteve ligada ao plano de transformar a Ilha Grande em um Porto Militar e nada tem a ver com a proteção 
do litoral nos séculos XVIII e XIX, diferente da afirmação do Exército. Suas características construtivas são totalmente diferentes das identificadas em Piraquara, Angra dos Reis e na Ponta Leste: o Forte do Leme apresenta construções de alvenaria e é uma obra defensiva permanente, formada por quartel, retaguarda, banheiro, galerias e Casa do Comandante. Sua artilharia, mais avançada do que os canhões de Angra dos Reis, tem alcance e precisão maior. Mesmo que não haja relação direta com as estruturas defensivas mais antigas, o Forte do Leme foi construído no mesmo local que elas e, provavelmente, uma das formas de acessá-lo era feita pela praia onde estão tais estruturas.

Independente do caráter provisório ou permanente destas fortificações, todas as estruturas defensivas demonstram, sobretudo, a preocupação da colônia e do Estado Nacional em manter suas fronteiras. O risco de invasão era corrente e a cidade do Rio de Janeiro, principalmente, deveria ser protegida, se não por armas potentes, mas pelo menos por um esquema de sinalização entre o litoral.

Na Baía da Ilha Grande, o sistema de sinalização e proteção era subdividido entre Sepetiba, Angra dos Reis e Paraty, por conta de sua extensão. Muito mais do que possuir armas potentes, essas estruturas defensivas eram importantes para sinalizar em caso de invasão e, em conjunto com uma rede de vigias instaladas ao longo do litoral, propiciavam a chegada rápida do aviso ao Rio de Janeiro (OLIVEIRA e FUNARI, 2007, p. 23).

Em todo o litoral sul fluminense apenas a constante vigilância das praias constituía a segurança da extensa área frente ao mar, infestada por corsários e piratas. Assim, os pontos considerados estratégicos foram aproveitados pelo governo para a implantação de baterias, muralhas, faxinas, vigias etc. Muitas pesquisas ainda serão necessárias para compreender todas as estratégias defensivas utilizadas na região. O objetivo deste estudo foi indicar alguns elementos que possam contribuir para essa interpretação. Entretanto, como dito, esses são apenas os primeiros passos. 


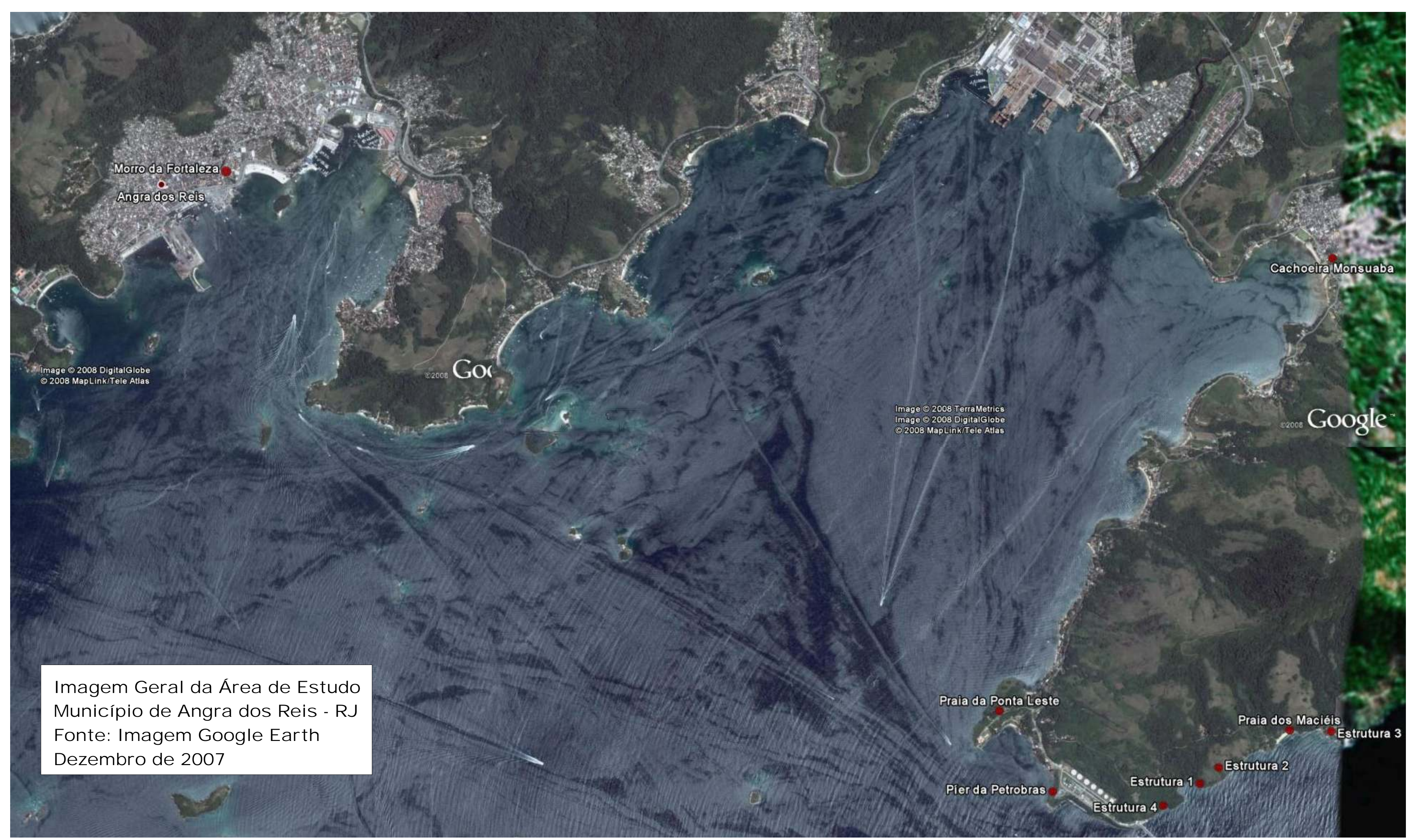




\section{Bibliografia}

\section{Fontes Primárias}

\section{Sobre a defesa da Baía de Ilha Grande}

20/04/1617. Carta de Martim de Sá a Felipe II, sobre as preferências dos estrangeiros, para se refrescarem, pelas ilhas de São Sebastião, Grande, dos Porcos, Sant' anna e Santa Catarina. MELLO, C. E. H. V. Apontamentos para servir à história fluminense (Ilha Grande), Angra dos Reis, Ilha Grande. Angra dos Reis: Conselho Municipal de Cultura, 1987, p. 15.

21/03/1696. Carta sobre a estadia de De Gênes em Angra dos Reis, Sebastião de Castro e Caldas repreende os membros da Câmara. MELLO, C. E. H. V. Apontamentos para servir à história fluminense (Ilha Grande), Angra dos Reis, Ilha Grande. Angra dos Reis: Conselho Municipal de Cultura, 1987, p. 65.

08/03/1699. Livro dos Acord. afs. 145 sobre náos francesas, que vierão ao Porto da Ilha Grande. Revista do IHGB, Vol 271 - abril, junho, 1966. Capítulo IV - Vários documentos de Angra dos Reis da Ilha Grande e outros lugares da Capitania do Rio de Janeiro, p. 322.

17/06/1699. Livro dos Acord. afs. 147 sobre náos francesas, que vierão ao Porto da Ilha Grande. Revista do IHGB, Vol 271 - abril, junho, 1966. Capítulo IV - Vários documentos de Angra dos Reis da Ilha Grande e outros lugares da Capitania do Rio de Janeiro, p. 322-323.

17/06/1699. Livro dos Acord. afs. 147 sobre Quartel na Vila de Angra dos Reis. Revista do IHGB, Vol 271 - abril, junho, 1966. Capítulo IV - Vários documentos de Angra dos Reis da Ilha Grande e outros lugares da Capitania do Rio de Janeiro, p. 325.

27/09/1703. Sobre os Descaminhos do ouro. Arquivo Nacional. Códice 952, Vol 14, ft. 0204.

08/02/1704. Sobre o mandar-se o Capitão de Engenheiros à Ilha Grande ver se podia fazer alguma fortificação para a defesa da llha. Governador do Rio de Janeiro - Dom Álvaro da Silveira. MENDES, A. Ouro, incenso e mirra: narrativas históricas sobre Angra dos Reis. Angra dos Reis: Gazeta de Angra, 1970, p. 391.

18/09/1704. Resposta Rainha da Grã-Bretanha - infanta de Portugal. MENDES, A. Ouro, incenso e mirra: narrativas históricas sobre Angra dos Reis. Angra dos Reis: Gazeta de Angra, 1970, p. 392.

07/06/1706. Sobre franceses na Vila de Angra dos Reis. Arquivo Nacional. Cód. 952 - vol. 16, ft. 1016. 
11/06/1706. Fortificação em Paraty. Arquivo Nacional. Cód. 952 - vol. 16, ft. 1081.

16/08/1710. Relação da chegada da Armada Francesa a este Rio de Janeiro. Revista do Ateneu Angrense, ano IV, n. 2 , junho de 1976, p. 48.

26/02/1718. Carta do Governador Antônio Brito de Meneses a Tomás Gomes da Guarnição de Angra dos Reis sobre a ação dos piratas na Ilha Grande. MELLO, C. E. H. V. Apontamentos para servir à história fluminense (Ilha Grande), Angra dos Reis, Ilha Grande. Angra dos Reis: Conselho Municipal de Cultura, 1987, p. 58.

01/10/1719. Translado da Patente do Coronel Lourenço Carvalho da Cunha. Reg. afs. 173. Revista do IHGB, vol 271 - abril, junho, 1966. Capítulo IV Vários documentos de Angra dos Reis da Ilha Grande e outros lugares da Capitania do Rio de Janeiro,

p. 325-327.

03/07/1725. Sobre Paraty e Ilha Grande. Archivo Nacional, Governadores do Rio de Janeiro, Correspondência activa e passiva com a Côrte, 17251730, p. 15.

08/11/1725. Regimento sobre os navios estrangeiros. Revista do IHGB, vol 271 - abril, junho, 1966. Capítulo IV - Vários documentos de Angra dos Reis da Ilha Grande e outros lugares da Capitania do Rio de Janeiro, p. 363-365.

17/10/1725. Para o secretário de Estado pella Bahya sobre o Navio Dom Carlos e asustatoria dos frades. Archivo Nacional, Governadores do Rio de Janeiro, correspondência activa e passiva com a Côrte, 1725- 1730, p. 4547.

26/01/1726. Sobre assistir 500 mil réis para se fazerem quartéis na Ilha Grande. Archivo Nacional, Governadores do Rio de Janeiro, Correspondência activa e passiva com a Côrte, 1725- 1730, p. 69-70.

17/03/1726. Pelo Conselho-sobre o Navio D. Carlos. Archivo Nacional, Governadores do Rio de Janeiro, Correspondência activa e passiva com a Côrte, 1725- 1730, p. 50-53.

16/07/1726. Resposta de Luis Vahia Monteiro. Archivo Nacional, Governadores do Rio de Janeiro, Correspondência activa e passiva com a Côrte, 1725- 1730, p. 70.

06/07/1726. Sobre as arribadas dos Navios Dom Carlos, Mercúrio, Bejamin, e Aurora, de que se remetem os autos. Archivo Nacional, Governadores do Rio de Janeiro, Correspondência activa e passiva com a Côrte, 17251730, p. 124-126. 
07/11/1726. Sobre fortificar a Vila de Angra dos Reis da Ilha Grande e vila de Paraty. Archivo Nacional, Governadores do Rio de Janeiro, Correspondência activa e passiva com a Côrte, 1725- 1730, p. 158-159.

14/11/1726. Sobre o requerimento da Câmara da Ilha Grande que pede os privilégios que tem os desta cidade. Archivo Nacional, Governadores do Rio de Janeiro, Correspondência activa e passiva com a Côrte, 1725- 1730, p. 203.

06/07/1727. Resposta de Luiz Vahia Monteiro. Archivo Nacional, Governadores do Rio de Janeiro, Correspondência activa e passiva com a Côrte, 1725- 1730, p. 203-204.

31/07/1727. Sobre o ofício do Provedor do Registro da Vila de Paraty. Archivo Nacional, Governadores do Rio de Janeiro, Correspondência activa e passiva com a Côrte, 1725- 1730, p. 221.

1728. Noveau Voyage Antorir du Monde, Le Gentil Labarbinais. Revista do Ateneu Angrense - ano III, $\mathrm{n}^{\circ}$ 4, p. 20.

02/05/1732. Ofício de Luis Vahia Monteiro ao alferes João da Costa, comandante da Fortaleza do Carmo. MENDES, A. O velho convento: anotações para a história dos frades franciscanos em Angra dos Reis. $2^{\mathrm{a}}$ Edição. Angra dos Reis: Gazeta de Angra, 1988, p. 36.

20/05/1732. Ofício de Luís Vahia Monteiro ao Frei Manoel de São Roque, guardião do primeiro Convento de São Bernardino. MENDES, A. O velho convento: anotações para a história dos frades franciscanos em Angra dos Reis. $2^{a}$ Edição. Angra dos Reis: Gazeta de Angra, 1988, p. 37.

Anno de 1737. Cópia da Carta que os officiaes da Câmara escreverão a Sua Magestade. Revista do IHGB, vol 271 - abril, junho, 1966. Capítulo IV - Vários documentos de Angra dos Reis da Ilha Grande e outros lugares da Capitania do Rio de Janeiro, p. 365.

1793. Relato de uma inspeção do Sargento-Mor Joaquim Correa da Serra, a mando do governo colonial das defesas da Ilha Grande, Paraty, em 1793, com ordens para fazer obras, se necessário. Biblioteca Nacional - Seção Manuscritos - Notícias de Ilha Grande e Paraty - II, 31,21,4.

1797. Estado das fortificações em Nossa Senhora da Conceição de Angra dos Reis da Ilha Grande e Nossa Senhora dos Remédios em Paraty. Revista do Ateneu Angrense, ano III, $\mathrm{n}^{\circ} 4-12 / 1975$, p. 5.

16/03/1797. Carta Enviada ao Vice-Rey por Pedro Álvares de Andrade. Revista do Ateneu Angrense, ano III, no 4 - 12/1975, p. 6-7.

08/09/1822. Registo da Carta de Offício do Governador Militar Manoel Joaquim Pereira. RAMECK, M. J.; MELLO, D. Roteiro Documental do ACERVO Público de Paraty - 1801-1883, p. 79. 
14/02/1826. Defesa de Angra dos Reis e Paraty a respeito dos piratas. Revista do Ateneu Angrense de Letras e Artes, ano V, n 1, p. 40.

01/04/1826. Defesa de Angra dos Reis e Paraty a respeito dos piratas. Revista do Ateneu Angrense de Letras e Artes, Ano $\vee n^{\circ} 1$, p. 41.

13/11/1826. Embarcações aprisionadas. Revista do Ateneu Angrense de Letras e Artes, ano $\vee \mathrm{n}^{0} 1, \mathrm{p} .43$.

13/11/1826. Sobre corsários na Vila de Paraty. Revista do Ateneu Angrense de Letras e Artes, ano V, n 1, p.44.

27/11/1826. Registo do Offício, q'esta Câmara de Paraty dirigio ao Governador Militar desta Vila da Ilha Grande. RAMECK, M. J.; MELLO, D. Roteiro Documental do ACERVO Público de Paraty - 1801-1883, p. 80.

30/11/1826. Registo da resposta do Offício. RAMECK, M. J.; MELLO, D. Roteiro Documental do ACERVO Público de Paraty - 1801-1883, p. 80-81.

30/11/1826. REGISTRO DO Edital. (...) Senado da Camara d'esta Villa de Nossa Senhora dos Remédios de Paraty RAMECK, M. J.; MELLO, D. Roteiro Documental do ACERVO Público de Paraty - 1801-1883, p. 81.

30/11/1826. Registro de dois Officios do Governador Militar. RAMECK, M. J.; MELLO, D. Roteiro Documental do ACERVO Público de Paraty - 18011883, p. 80-81.

30/11/1826. Registro de Officio do Governador Militar. RAMECK, M. J.; MELLO, D. Roteiro Documental do ACERVO Público de Paraty - 18011883, p. 82.

01/12/1826. Registro do Officio do Governador Militar. RAMECK, M. J.; MELLO, D. Roteiro Documental do ACERVO Público de Paraty - 18011883, p. 82.

02/12/1826. Offício de Anacleto José de Sousa Castro ao Presidente da Câmara da Villa de Nossa Senhora dos Remédios de Paraty. RAMECK, M. J.; MELLO, D. Roteiro Documental do ACERVO Público de Paraty - 18011883, p. 83.

28/09/1827. Correspondência entre Governo Imperial e Governador Militar da Ilha Grande. REIS, B. Apontamentos para a história de Angra dos Reis. Angra dos Reis: Conselho Municipal de Cultura, 1988, p. 23.

29/09/1827. Correspondência entre Governo Imperial e Governador Militar da Ilha Grande. REIS, B. Apontamentos para a história de Angra dos Reis. Angra dos Reis: Conselho Municipal de Cultura, 1988, p. 22.

01/10/1827. Correspondência entre Governo Imperial e Governador Militar da Ilha Grande. REIS, B. Apontamentos para a história de Angra dos Reis. Angra dos Reis: Conselho Municipal de Cultura, 1988, p. 24. 
19/06/1833. Resposta ao Offício. RAMECK, M. J.; MELLO, D. Roteiro Documental do ACERVO Público de Paraty - 1801-1883, p. 83. .

06/04/1838. Câmara Municipal de Angra dos Reis ao Vice Presidente do Rio de Janeiro. Arquivo do Estado do Rio de Janeiro, Fundo: P.P. Notação 099, no maço:06, caixa:0037.

27/06/1838. Câmara Municipal de Angra dos Reis ao Vice Presidente do Rio de Janeiro. Arquivo do Estado do Rio de Janeiro, fundo: P.P. Notação 099, n. maço:06, caixa:0037.

12/08/1850. Reg. de Officio que Camara de Paraty dirigio ao Governo d'esta Província, pedindo providencias sobre os reparos no Forte Defensor. RAMECK, M. J.; MELLO, D. Roteiro Documental do ACERVO Público de Paraty 1801-1883, p. 84.

01/02/1860. Câmara Municipal de Angra dos Reis ao Senhor Dr. Ignácio Francisco Silveira da Mota - Digno Presidente da Província do Rio de Janeiro. Arquivo do Estado do Rio de Janeiro, fundo: P.P. notação 0102, n. maço: 01, caixa: 0038.

13/02/1860. Resposta à Câmara de Angra dos Reis - Ignácio Francisco Silveira da Mota - Digno Presidente da Província do Rio de Janeiro. Arquivo do Estado do Rio de Janeiro, fundo: P.P. notação 0102, n. maço:01, caixa:0038.

15/03/1860. Offício dirigido ao Barão de Suruhy - por Manoel Roiz Barros Fonseca de Brito - Ajudante General do Exército. Arquivo Histórico do Exército - Caixa do acervo de Fortalezas.

Sobre a Ilha Grande e a Vila de Nossa Senhora da Conceição de Angra dos Reis da Ilha Grande

1673. Prática da Arte de Navegar, de Luiz Serrão Pimentel. Revista do Ateneu Angrense, ano III, $\mathrm{n}^{\circ} 2$, p. 58.

29/12/1695. Relation d'um Voyage...François Froger. Revista do Ateneu Angrense, ano III n. 3,1975 .

13/02/1823. Despacho de José Bonifácio de Andrada e Silva. MELLO, C. E. H. V. Apontamentos para servir à história fluminense (Ilha Grande), Angra dos Reis, Ilha Grande. Angra dos Reis: Conselho Municipal de Cultura, 1987, p. 19.

15 a 22/04/1886. Excursão Ministerial, Raul Pompéia, Gazeta da Tarde. Revista do Ateneu Angrense, ano III, nº 4, p. 19. 


\section{Documentos sobre a Vila de Santos e São Vicente}

24/04/1690. Registro da Carta de Sua Magestade ao governador desta praça sobre o que manda lhe acuda com todo o necessário para a defença do inimigo. Arquivo Nacional, Códice 61, vol 9, p. 23. Documento fotografado: PP1190056 A 61.

20/01/1704. Registro da Carta de Sua Magestade escrita ao governador desta Capitania Artur de Sá Meneses sobre a forma em que se deve socorrer alguma embarcação vinda de Santos. Arquivo Nacional, Códice 61, vol 14, p. 96 v. Documento Fotografado: PP1190120 a 123.

20/09/1725. Sobre se haverem de remeter dinheiro para a praça de Santos. Archivo Nacional, Governadores do Rio de Janeiro, Correspondência activa e passiva com a Côrte, 1725- 1730, p. 68.

\section{Documentos sobre Caminhos}

08/12/1701. Representação do Conselho Ultramarino a El-Rei. GURGEL, H.; AMARAL, E.. Paraty: caminho do ouro. Rio de Janeiro: Livraria São José, 1973, p. 43.

1702. Regimento das Minas - Arthur Sá de Meneses. GURGEL, H.; AMARAL, E. Paraty: caminho do ouro. Rio de Janeiro: Livraria São José, 1973, p. 43.

05/07/1726. Resposta de Luís Vahia Monteiro sobre os caminhos. Archivo Nacional, Governadores do Rio de Janeiro, Correspondência activa e passiva com a Côrte, 1725- 1730, p. 143.

14/10/1726. Sobre se dar toda ajuda necessária para abertura do caminho de São Paulo para esta cidade. Archivo Nacional, Governadores do Rio de Janeiro, Correspondência activa e passiva com a Côrte, 1725- 1730, p. 191.

07/11/1726. Sobre a arrecadação dos dízimos. Archivo Nacional, Governadores do Rio de Janeiro, Correspondência activa e passiva com a Côrte, 1725- 1730, p. 161.

06/07/1727. Resposta de Luis Vahia Monteiro sobre caminhos. Archivo Nacional, Governadores do Rio de Janeiro, Correspondência activa e passiva com a Côrte, 1725- 1730, p. 192.

\section{Documentos sobre o Forte do Leme}

03/1909. Fé de Offício do Senhor Capitão da Arma de Engenharia Rosalvo Mariano Silva. Arquivo Histórico do Exército, Setor Pessoal XXX/24/177

14/06/1909. Noticiário da Ponta do Leme. Reportagem da Gazeta de Angra, n.24, Biblioteca Nacional. 
11/07/1909. Comissão Militar. Reportagem da Gazeta de Angra, n. 28, Biblioteca Nacional.

12/12/1909. A questão do Arsenal - Sobre a Ilha Grande. Reportagem da Gazeta de Angra, Biblioteca Nacional.

02/1910. Fé de Offício do Senhor Capitão da Arma de Engenharia Rosalvo Mariano Silva. Arquivo Histórico do Exército, Setor Pessoal XXX/24/177.

05/1911. Fé de Offício do Senhor Capitão da Arma de Engenharia Rosalvo Mariano Silva. Arquivo Histórico do Exército, Setor Pessoal XXX/24/177. 25/06/1911. A defesa de nosso litoral. Reportagem da Gazeta de Angra, n. ${ }^{\circ}$ 26, Biblioteca Nacional.

30/07/1911. Terra e Mar. Reportagem da Gazeta de Angra, n. ${ }^{\circ} 34$, Biblioteca Nacional.

29/10/1911. Visita Presidencial: Escola de Grumetes, Forte do Leme, Marechal Hermes da Fonseca, Reportagem da Gazeta de Angra, $n^{\circ} 44$, Biblioteca Nacional.

02/1916. Fé de Offício do Senhor Capitão da Arma de Engenharia Rosalvo Mariano Silva. Arquivo Histórico do Exército, Setor Pessoal XXX/24/177.

Outras fontes primárias

ANTONIL, A. J. $\{1711\}$. Cultura e Opulência do Brasil. Belo Horizonte/São Paulo: Itatiaia/Edusp, 1982.

ARAÚJO, J. S. A. P. \{1820\}. Memórias históricas do Rio de Janeiro. Rio de Janeiro: Imprensa Nacional, 1945, volume 2.

KIDDER, D. P. $\{1845\}$. Reminiscências de viagens e permanências nas províncias do sul do Brasil (Rio de Janeiro e Província de São Paulo). Belo Horizonte/São Paulo: Itatiaia/Edusp, 1980.

LUCCOCK, J. \{1820\}. Notas sobre o Rio de Janeiro e partes meridionais do Brasil. Belo Horizonte/São Paulo: Itatiaia/Edusp, 1975.

MAWE, J. $\{1808\}$, Viagens ao interior do Brasil: principalmente dos distritos do ouro e dos diamantes. Tradução: Solena Benevides Viana. Introdução e notas de Clado Ribeiro de Lessa. Rio de Janeiro: Zélio Valverde, 1944.

POHL, J. E. $\{1832\}$. Viagem ao interior do Brasil. Belo Horizonte: Itatiaia, 1976.

Relatório do Marquês de Lavradio, 19 de junho de 1779. Revista Trimestral de História e Geographia ou Jornal do Instituto Histórico e Geográfico Brasileiro, n. ${ }^{\circ} 16$, janeiro de 1843. 


\section{Fontes secundárias}

ALBUQUERQUE, M. A. G. M. As Escavações Arqueológicas no Forte de Orange. In: III Simpósio de técnicas Avançadas em Conservação de Bens Culturais, 2006.

AlBuqueRQue, M. A. G. M. O Forte do Brum. Rio de Janeiro: Fundação Cultural Exército Brasileiro, 2008.

ALBUQUERQUE, M.; LUCENA, V. Forte Real do Bom Jesus: resgate arqueológico de um Sítio Histórico. Recife, CEPE, 1988.

AlBuQueRQuE, M. A. G. M.; LUCENA, V;. Projeto Arqueológico Forte Orange, Itamaracá-PE - Resumo dos resultados referentes a escavação arqueológica. In: XII Congresso da Sociedade de Arqueologia Brasileira: Arqueologia da America Latina, 2003, São Paulo.

AMENOMORI, S. N. Paisagens da Ilha, as Ilhas da Paisagem: a ocupação dos grupos pescadores-coletores pré-históricos do litoral norte de São Paulo. Tese (Doutorado em Arqueologia), Museu de Arqueologia e Etnologia, Universidade de São Paulo, 2005.

ANDREATTA, M. D. Casa do Grito-Ipiranga, Programa de Arqueologia Histórica no município de São Paulo. Revista do Arquivo Municipal, São Paulo, 1986.

ANDREATTA, M. D. Igreja velha guarda séculos de história. Diário do Grande ABC, 13 jun. 1991.

ANDREATTA, M. D. Arqueologia Histórica Industrial. Diário de Mogi, Mogi das Cruzes, 18 nov. 1992a.

ANDREATTA, M. D. Arqueologia Histórica Industrial - Bairro da Fundação. São Caetano do Sul. Folha de São Paulo, 17 nov. 1992b.

ANDREATTA, M. D. Arqueologia Histórica Industrial: um patrimônio em São Paulo. Suplemento do Diário Oficial do Estado de São Paulo, Imprensa Oficial SP, p. 1 - 4, 25, 2003.

ANDRÉN, A. Between artefacts and texts. Historical Archaeology in global perspective. New York and London, Plenum Press, 1998.

BARRETO, A. Fortificações no Brasil (Resumo Histórico). Rio de Janeiro: Biblioteca do Exército - Editora, 1958.

BORGES, B. Angra dos Reis, King's Bay, Ilha Grande, Paraty. 1988.

BORNAL, W. G. Sítio Histórico São Francisco 01 - contribuição à Arqueologia Histórica. Dissertação (Mestrado em Arqueologia), Museu de Arqueologia e Etnologia, Universidade de São Paulo, 1995. 
BORNAL, W. G. O sítio histórico São Francisco sob a ótica da Arqueologia da Paisagem - São Sebastião - SP. Tese (Doutorado em Arqueologia), Museu de Arqueologia e Etnologia da Universidade de São Paulo, 2008.

BRANCHELLI, F. A. Vida material e econômica da Porto Alegre oitocentista. Dissertação (Mestrado em História), Faculdade de Filosofia e Ciências Humanas, PUC, Porto Alegre, 2007.

BRUNEAU, P. Fontes textuais e vestígios materiais: reflexões sobre a interpretação arqueológica. In: Mélanges G. Dáux. Texto datilografado, tradução Flávia Faleiros. Paris, 1974. Suppl. BCH, 4-42.

BRUNO, E. S. A cidade, o mar e as serras:São Paulo: Cultrix, 1959.

BUENO, B. P. S. Desenho e Desígnio: o Brasil dos Engenheiros Militares (1500-1822). Tese (Doutorado em Arquitetura), Faculdade de Arquitetura e Urbanismo da Universidade de São Paulo, 2001.

BURKE, P. A Escrita da História. São Paulo: Editora UNESP, 1992.

CAMARGO, P. B. Arqueologia das Fortificações Oitocentistas da Planície Costeira Cananéia/lguape. Dissertação (Mestrado em Arqueologia), Museu de Arqueologia e Etnologia, Universidade de São Paulo, São Paulo, 2002.

CAMPOS, J. S. Fortificações da Bahia. Rio de Janeiro, Ministério da Educação e Saúde, 1940.

CAPAZ, C. Memórias de Angra dos Reis. Rio de Janeiro: Asas Artes Gráficas Ltda., 1996.

CARR, E. H. Que é História? Tradução de Lúcia Maurício, Rio de Janeiro: Paz e Terra, 1996.

CLARK, G. A identidade do Homem: uma exploração arqueológica. Rio de Janeiro: Jorge Zahar, 1985.

CONCEIÇÃO, A. A. Lidas novamente...a escrita de cartas como prática do governo colonial (século XVIII). Anais do XXIII Simpósio Nacional de História, Cd-rom, Londrina, julho, 2005, p. 1-8.

COURBIN, P. What is Archaeology? An Essay on the Nature of Archaeological Research. Chicago: The University of Chicago Press, 1988.

DIAS, A. S. Um projeto para a arqueologia brasileira: breve histórico da implementação do Programa Nacional de Pesquisas Arqueológicas (PRONAPA). Revista do CEPA, Santa Cruz do Sul, v. 19, n. 22, p. 25-39, 1995. 
DOMíNGUEZ, L.; FUNARI, P. P. A. Arqueología de los esclavos africanos e indígenas en Brasil y Cuba 2008. Revista de História da Arte e Arqueologia, v. IX, p. 1-20, 2008.

DURAN, L. Piratas, corsários ou contrabandistas? O caso de Santos. 2004. Disponível em http://www.historiaehistoria.com.br/materia.

ELLIS, M. A baleia no Brasil colonial. São Paulo, Edusp, 1968.

FALCÃO, E. C. Fortes coloniais da cidade de Salvador. São Paulo: Livraria Martins, 1942.

FERREZ, G. O Rio de Janeiro e a defesa do seu porto. Rio de Janeiro: Serviço de Documentação Geral da Marinha, Rio de Janeiro, 1972.

FILHO, D. S. A. Angra dos Reis: monumentos históricos entre a indústria e o paraíso. Dissertação (Mestrado em Planejamento Urbano e Regional)Universidade Federal do Rio de Janeiro, Rio de Janeiro, 2004.

FINLEY, M. Usos e abusos da História. São Paulo: Martins Fontes, 1994.

FLORENZANO, M. B. B. Arqueologia Clássica e Ciências Humanas. Anos 90. Revista do Programa de Pós-graduação em História, n. 17, 2003, p. 13-23.

FRANCHI, C. Arqueologia histórica do baixo Vale do Ribeira: inventários dos sítios entre Iguape e Icapara. Dissertação (Mestrado em Arqueologia), Museu de Arqueologia e Etnologia, Universidade de São Paulo, 1999.

FRANCISCO, G. S. Grafismos gregos: escrita e figuração na cerâmica Ática do período arcaico (do século VII-VI a.C.). Dissertação (mestrado em Arqueologia), Museu de Arqueologia e Etnologia, Universidade de São Paulo, São Paulo, 2007.

FREITAS, B. Santa Cruz - Fazenda Jesuíta, Real e Imperial. Volume II. Vice Reino e Reinado 1760-1821. Rio de Janeiro: Asa Artes Gráficas, 1986.

FUNARI, P. P. A. Memória histórica e cultura material. Revista Brasileira de História. São Paulo, v. 13, n. ${ }^{\circ}$ 25-26, 1993, p. 17-31.

FUNARI, P. P. A. Arqueologia de Palmares. Carta, Brasília, v. 7, p. 62-63, 1995.

FUNARI, P. P. A. A "República de Palmares" e A Arqueologia da Serra da Barriga. REVISTA USP, v. 28, p. 6-13, 1996a.

FUNARI, P. P. A. A Cultura Material de Palmares: O Estudo das Relações Sociais de um Quilombo pela Arqueologia. IDEIAS, São Paulo, v. 27, p. 37-42, 1996b. 
FUNARI, P.P. Teoria Arqueológica na América do Sul. Primeira Versão. Vol. 76. Campinas: UNICAMP, 1998, p. $13-32$.

FUNARI, P. P. A. Historical Archaeology from a world perspective. In: FUNARI, P.P.A.; JONES, S.; HALL, M.(Ed.). Historical Archaeology: Back from the Edge, Londres: Routldge, 1999, p. 37-63.

FUNARI, P. P. A. A Arqueologia Histórica em uma perspectiva mundial. In: ZARANKIN, A.; SENATORE, M. X. (Ed.). Arqueologia da Sociedade Moderna da América do Sul. Buenos Aires: Ediciones Del Tridente, 2002, p. 107-115.

FUNARI, P. P. A. Os avanços da Arqueologia Histórica no Brasil, um balanço Comciência, Campinas, Ano 2003. Disponível em http://www.comciencia.br/reportagens/arqueologia/arq13.shtml.

FUNARI, P. P. A. Teoria e métodos na Arqueologia contemporânea: o contexto da Arqueologia Histórica. Dossiê Arqueologias Brasileiras, v.6, n. 13, Ano, 2004-2005. Disponível em: <http://www.seol.com.br/mneme>.

FUNARI, P. P. A. Apresentação. In: BERNAL, M.; CANFORA, L., FUNARI, P. P. A.; OLIVIER, L. (Ed.). Repensando o mundo antigo. Campinas: IFCH/UNICAMP, n. ${ }^{\circ}$ 49, p. 5 - 9, 2005.

FUNARI, P. P. A. Gestão, preservação e acesso a documentos digitais: patrimônio cultural e diversidade 23/11/2006. Cadernos do CEOM, v. 18, 22, p. 213-229, 2006.

FUNARI, P. P. A. A report on Historical Archaeology Publications in Latin America. International Journal of Historical Archaeology, v. 11, p. 97-106, 2007.

FUNARI, P. P. A.; CARVALHO, A. Palmares, ontem e hoje. Rio de Janeiro: Jorge Zahar, 2005.

FUNARI, P. P. A.; JONES, S.; HALL, M. Introduction: Archaeology in History. In: FUNARI, P. P. A.; JONES, S.; HALL, M.(Ed.). Historical Archaeology: Back from the Edge, Londres: Routledge, 1999. p.1-23.

FUNARI, P. P. A.; OLIVEIRA, N. V. Arqueologia em Angra dos Reis, Rj. n. ${ }^{\circ}$ $55,2005$.

FUNARI, P. P. A.; ORSER JR, C. Pesquisa arqueológica inicial em Palmares. Estudos Ibero-Americanos, Porto Alegre, v. 18, n. 2, p. 53-69, 1992.

FUNARI, P. P. A.; ZARANKIN, A. (Ed.). Arqueología de la represión y la resistencia en América Latina 1960-1980, 01/10/2006. $1^{\mathrm{a}}$ ed. Catamarca: Universidad Nacional de Catamarca, 2006. 
GINZBURG, C. Relações de força: história, retórica, prova. Trad. Jonatas Batista Neto. São Paulo: Companhia das Letras, 2002.

GOMES, R. C. Letters and letter-writting in fifteenth century Portugal. In: SCHULTE, R., TIPPELSKIRCH, X. V. (Ed.). Reading, interpreting and historicizing: letters as historical sources. Florence: European University Institute - Departament of History and Civilization, 2004, p. 11-37.

GUIMARÃES, C. M. Os Quilombos do Século do Ouro. Revista do Departamento de História Fafich Ufmg, Belo Horizonte, p. 15-46, 1988.

GUIMARÃES, C. M. Quilombos e Brecha Camponesa. Revista do Departamento de História Fafich Ufmg, Belo Horizonte, v. 8, p. 28-37, 1989.

GUIMARÃES, C. M. Mineração colonial e arqueologia: potencialidades. Revista de Arqueologia, Rio de Janeiro/Sociedade de Arqueologia Brasileira, Brasil, v. 9, p. 55-64, 1996.

GUIMARÃES, C. M. Os Africanos. Cícero, Belo Horizonte, v. 1, p. 126-132, 2000.

GUIMARÃES, C. M. Os Cabeças e as cabeças: quilombos, liderança e degola nas Minas setecentistas. Varia História, Belo Horizonte, v. 26, p. 109-131, 2002.

GUIMARÃES, C. M. Os Quilombos, a noite e a aguardente nas Minas Gerais. In: Renato Pinto Venâncio; Henrique Carneiro. (Org.). Álcool e drogas na história do Brasil. $1^{\circ}$ ed. São Paulo: Alameda, 2005, v. único, p. 93-122.

GUIMARÃES, C. M.; LANNA, A. L. D. Arqueologia de Quilombos em Minas Gerais. Revista de Antropologia, v. 31, p. 23-28, 1980.

GUIMARÃES, C. M.; NASCIMENTO, E. ; SILVA, E. ; VELOSO, G. Para uma Arqueologia do Campesinato. In: XIII Congresso da Sociedade de Arqueologia Brasileira: Arqueologia, Patrimônio e Turismo, 2005, Campo Grande/MS. Anais do XIII Congresso da Sociedade de Arqueologia Brasileira: Arqueologia, Patrimônio e Turismo, 2005.

GURGEL, H.; AMARAL, E. Paraty: caminho do ouro. Rio de Janeiro: Livraria São José, 1973.

HODDER, I. Reading the past. Current approaches to interpretacion in archaeology. Cambridge University Press, 1986.

HODDER, I. Interpretación en Arqueologia. Corrientes Actuales. Cambridge World Archaeology, Cambridge University Press, 1994.

JOHNSON, M. H. Rethinking historical archaeology. In: FUNARI, P. P. A.; JONES, S.; HALL, M.(Ed.).Historical Archaeology: Back from the Edge. Londres: Routledge, 1999, p. 23-36. 
KERN, A. A. A Arqueologia Histórica: A História e os Trinta Povos das Missões. Revista das II Jornadas Internacionales sobre las Misiones Jesuíticas, posadas, Argentina, p. 37-43, 1986.

KERN, A. A. Missões Jesuítico-Guaranís; as pesquisas atuais. Missões 30 anos, A Visão do Artista. Arte sobre Arte: uma visão contemporânea sobre as Missões, São Paulo, p. 52, 1987.

KERN, A. A. Missões: um processo de dominação ou de transculturação? Revista Veritas, Porto Alegre/RS, v. 36, p. 129-136, 1991.

KERN, A. A. A Fonte: Memória e História das Missões Jesuítico-Guaranis. Caderno do Centro de Pesquisas Literárias, v. 1, p. 17-25, 1997.

KERN, A. A. 1973-1998: um programa de ensino e pesquisa completa vinte e cinco anos de consolidação e maioridade.Estudos Iberoamericanos, PUCRSPorto Alegre, v. 24, 1998.

KERN, A. A. Tradição e transformações históricas nas fronteiras coloniais: jesuítas, guaranis e sexualidade. Revista Brasileira de História, São Paulo, 2000.

KERN, A. A. O futuro do passado. os arqueólogos do novo milênio. Trabalhos de Antropologia e Etnologia (Sociedade Portuguesa de Antropologia e Etnologia), Porto, Portugal, v. 42, n. 1-2, p. 115-136, 2002.

KERN, A. A. Arqueologia em sítios missioneiros coloniais platinos: as missões jesuíticas do Brasil. In: Antonio Austral; Marcela Tamagnini. (Org.). Problemáticas de la Arqueologia Contemporánea. Rio Cuarto, Argentina: Universidad Nacional de Rio Cuarto, 2006, v. 1, p. 31-42.

LARA-LÓPEZ, E. L. La fotografia como documento histórico-artístico y etnográfico: una epistemología. Revista de Antropologia Experimental, n. 5, 2005, p. 1-28.

LIMA, H. Notícia Histórica e Geográfica de Angra dos Reis. 1889. Rio de Janeiro: Liv. São José, 1974.

MACHADO, N. T. Entre Guardas e Casarões: um pouco da história do interior do Rio Grande do Sul. Tese (Doutorado em Arqueologia), Museu de Arqueologia e Etnologia, Universidade de São Paulo, 2004.

Manual de preenchimento da Ficha de Inventário Nacional de Material de Artilharia, 1999.

MAXIMINO, E. P. B. Porto de Santos e o Portinho dos Piratas em retrospectiva: um estudo de arqueologia industrial. Tese (Doutorado em Arqueologia), Museu de Arqueologia e Etnologia, Universidade de São Paulo, 1997. 
MELLO, C. E. H. V. Apontamentos para servir à história fluminense (Ilha Grande), Angra dos Reis, Ilha Grande. Angra dos Reis: Conselho Municipal de Cultura, 1987.

MENDES, A. Ouro, incenso e mirra: narrativas históricas sobre Angra dos Reis. Angra dos Reis: Gazeta de Angra, 1970.

MENDES, A. O convento de Nossa Senhora do Carmo da Ilha Grande: apontamentos para a história dos frades carmelitas em Angra dos Reis. Angra dos Reis: [s.n], 1980.

MENDES, A. Angra dos Reis e a Marinha. Angra dos Reis: Gazeta de Angra, 1983.

MENDES, A. O velho convento: anotações para a história dos frades franciscanos em Angra dos Reis. 2a Edição. Angra dos Reis: Gazeta de Angra, 1988.

MILHEIRA, R. Arqueoistoriografia e Identidade no contexto das pesquisas arqueológicas em Sambaquis. Disponível no site http://www.cph.ipt.pt/angulo2006/img/01-02/sambaquis.pdf. Acesso em 10/04/2008.

MORELAND, J. Objects and texts in context. Archaeology and Text. Avon: Duckworth, 2001, p. 77-97.

MORI, V. H. Arquitetura Militar: um panorama histórico a partir do Porto de Santos. Imprensa Oficial do Estado de São Paulo / Fundação Cultural Exército Brasileiro. S. Paulo: 2003

MOTTA, J. F. Corpos escravos, vontades livres. Posse de escravos e família escrava em Bananal (1801-18029). São Paulo: FAPESP/Annablume, 1999.

NAJJAR, R. A catequese vista pela ótica da Arqueologia: um estudo comparativo entre três igrejas jesuíticas no litoral do Brasil. Tese (Doutorado em Arqueologia), Museu de Arqueologia e Etnologia, Universidade de São Paulo, 2005.

NORONHA, A. H. O. Fortificações construídas pelos portugueses no Brasil. Fundação Cultural Brasil-Portugal, 1982.

OLIVEIRA, N. V. São Barnabé: Lugar e Memória. Tese (Doutorado em Antropologia), Departamento de História do Instituto de Filosofia e Ciências Humanas, Universidade Estadual de Campinas, 2002.

OLIVEIRA, N. V. Projeto Área Arqueológica de Piraquara, Angra dos Reis apresentado à Eletronuclear, 2003. 
OLIVEIRA, N. V. Relatório Parcial do Projeto "Área Arqueológica de Piraquara, Angra dos Reis", apresentado ao IPHAN, 2004.

OLIVEIRA, N. V.; FUNARI, P. P. Aspectos estratégicos do litoral sul fluminense: a contribuição da Arqueologia Histórica. Anais do XIV Congresso da Sociedade de Arqueologia Brasileira, SAB, Florianópolis, 2007.

OLIVEIRA, N. V.; FUNARI, P. P.; MARIA, J. B. Preservación y conservación de sítios arqueológicos em el estado de Rio de Janeiro: Arqueología em Angra dos Reis y Educación Patrimonial. In: El pasado contemporâneo: Trabajo de campo y Arqueología Pública em Suramérica. Buenos Aires: CONICET, 2008.

ORSER JR., C. E. A teoria de rede e a arqueologia da História Moderna. Revista MAE, São Paulo, Suplemento 3, 1999, p.87-101.

ORSER JR., C. E. Intoducción a la Arqueología Histórica. Buenos Aires: Asociación Amigos del Instituto Nacional de Antropología, 2000.

QUEIROZ, C. Interpretação arqueológica da Capela Nossa Senhora dos Remédios, Jacareí - SP. Dissertação (Mestrado em Arqueologia), Museu de Arqueologia e Etnologia, Universidade de São Paulo, 2006.

REIS, B. Apontamentos para a história de Angra dos Reis. Angra dos Reis: Conselho Municipal de Cultura, 1988.

Relatório de visita ao Forte do Leme, Ministério do Exército, Departamento de Ensino e Pesquisa, Diretoria de Assuntos Culturais (in mimeo), 1994.

ROBRAHN-GONZÁLEZ, E. M. Arqueologia e Sociedade no município de Ribeirão Grande, sul de São Paulo: ações em Arqueologia Pública ligadas ao Projeto de ampliação da Mina Calcária Limeira. Revista arqueologia Pública, São Paulo, n. ${ }^{\circ}$ 1, 2006, p. 63-122.

SARIAN, H. Mito e imagística nos Vasos Gregos. Phoînix, Rio de Janeiro, n. ${ }^{\circ}$ 5, 1999, p. 163-175.

SILVA, F. F. Fortificações brasileiras: máquinas de guerra e de memória. Tese (Doutorado em História), Faculdade de Filosofia, Letras e Ciências Humanas da Universidade de São Paulo, 1991.

SMALL, D. B. The tyranny of the text: lost social strategies in current historical period archaeology in the classical Mediterranean.In: FUNARI, P. P. A.; JONES, S.; HALL, M.(Ed.). Historical Archaeology: Back from the Edge, Londres, Routldge, 1999, p. 122-136.

SOUZA, A. M. História da Arqueologia Brasileira. São Leopoldo, Unisinos, 1991. 
SOUZA, M. M. Parati: a cidade e as festas. Rio de Janeiro: Editora UFRJ: Tempo Brasileiro, 1994.

TAVARES, A. L. A engenharia militar portuguesa na construção do Brasil. Rio de Janeiro: Biblioteca do Exército, 2000.

THOMPSON, E. P. A miséria da Teoria: ou um planetário de erros: uma crítica ao pensamento de Althusser. Trad. Waltensir Dutra. Rio de Janeiro: Kahar, 1981.

TRIGGER, B. G. Uma história do pensamento arqueológico. Trad. O. T. Serra, São Paulo: Odysseus, 2004.

UESSLER, C. O. Sítios arqueológicos de assentamentos fortificados ibero-americanos na região Platina Oriental. Tese (Doutorado em História), Faculdade de Filosofia e Ciências Humanas, PUC, Porto Alegre, 2006.

VASCONCELLOS, M. C. R. Famílias escravas em Angra dos Reis, 18011888. Tese (doutorado em História), Faculdade de Filosofia, Letras e Ciências Humanas, Universidade de São Paulo, São Paulo, 2006.

ZANETTINI, P. E. Arqueologia na caatinga: arqueologia de Canudos, em Canudos ou para Canudos? Comciência, Campinas, 2003. Disponível em http://www.comciencia.br/reportagens/arqueologia/arq19.shtml.

ZANETTINI, P. E. Maloqueiros e seus palácios de barro: o cotidiano doméstico na Casa Bandeirista. Tese (Doutorado em Pós-Graduação em Arqueologia) - Museu de Arqueologia e Etnologia da Universidade de São Paulo, 2005.

ZARANKIN, A. Arqueología de la Arquitectura, modelando al individuo disciplinado en la sociedad capitalista. Revista de Arqueología Americana, Mexico, v. 22, n. 1, p. 25-41, 2005.

ZARANKIN, A.; FUNARI, P. Eternal Sunshine of the Spotless Mind: Archaeology and Construction of Memory of Military Repression in South America (1960-1980). Archaeologies. World Archaeological Congress, v. 5, p. 74-91, 2008.

ZARANKIN, A.; SENATORE, $M$. X. Perspectivas metodologicas em Arqueologia Historica: Reflexiones sobre la utilización de la evidencia documental. Páginas sobre Hispano-América Colonial. Sociedad y cultura, n. ${ }^{\circ}$ 3, Buenos Aires, 1996, p. 113-122.

ZEQUINI, A. Arqueologia de uma fábrica de ferro: morro de Araçoiaba, séculos XVI-XVIII. Tese (Doutorado em Arqueologia), Museu de Arqueologia e Etnologia, Universidade de São Paulo, 2006. 
Anexo

\section{Fontes primárias digitalizadas}

\section{Documentos sobre a presença de navios estrangeiros e a defesa da Vila de Angra dos Reis}

\begin{tabular}{|c|c|}
\hline $\begin{array}{l}\text { Carta de Martim } \\
\text { de Sá a Felipe II, } \\
\text { sobre as } \\
\text { preferências dos } \\
\text { estrangeiros, } \\
\text { para se } \\
\text { refrescarem, } \\
\text { pelas ilhas de } \\
\text { São Sebastião, } \\
\text { Grande, dos } \\
\text { Porcos, } \\
\text { Sant'anna e } \\
\text { Santa Catarina. } \\
\text { 20/04/1617 }\end{array}$ & $\begin{array}{l}\text { "(...) porque alguns moradores daquelas ilhas tem trato e } \\
\text { correspondência com os inimigos, por serem alguns deles } \\
\text { homisiados das Capitanias e lhes dão mantimentos e ajuda } \\
\text { de carga de pau (brasil), se me deve dar ordens para me } \\
\text { obedecerem e eu os poder castigar e mudar das ditas ilhas, e } \\
\text { presos o mandar a esse reino". }\end{array}$ \\
\hline $\begin{array}{l}\text { Carta sobre a } \\
\text { estadia de De } \\
\text { Gênes em Angra } \\
\text { dos Reis, } \\
\text { Sebastião de } \\
\text { Castro e Caldas } \\
\text { repreende os } \\
\text { membros da } \\
\text { Câmara. } \\
\text { 21/03/1696 }\end{array}$ & $\begin{array}{l}\text { "Vossas Mercês se têm havido muito maus servidores de Sua } \\
\text { Majestade, (...), merecendo mandá-los castigar; pois não } \\
\text { substaram ao Capitão-Mor quando Ihes foi avisado de que } \\
\text { estavam navios estrangeiros na costa, e que indo a este porto } \\
\text { dois que não encontraram neste, Ines fizeram agasalho, e } \\
\text { lhes dessem mantimentos que tivessem a troco de ouro e } \\
\text { prata, ou gêneros, contanto que não fossem fazendas, que } \\
\text { haviam de pagar direitos a Sua Majestade, e indo lá depois } \\
\text { mais os navios me não fizeram aviso algum da sua chegada, } \\
\text { nem da saída, e agora fazem o mesmo da sua arribada que } \\
\text { consta-me terem lá chegado, me não têm feito aviso. E } \\
\text { Vossas Mercês não me emendarem em semelhantes } \\
\text { ocasiões obrigar-me-ão a que os castigue; na forma referida } \\
\text { Ihes podem assistir com todo o necessário tendo sem } \\
\text { embargo disso as cautelas que já Ihes adverti, e se devem ter } \\
\text { havido navios estrangeiros no porto (...)". }\end{array}$ \\
\hline $\begin{array}{l}\text { Termo de } 8 \text { de } \\
\text { março de } 1699 . \\
\text { Livro dos Acord. } \\
\text { afs. } 145 \text { sobre } \\
\text { náos francesas, } \\
\text { que vierão ao } \\
\text { Porto da Ilha } \\
\text { Grande. } \\
\text { 08/03/1699 }\end{array}$ & $\begin{array}{l}\text { "Aos oito dias do mês de Março de mil seissentos e noventa e } \\
\text { nove annos nesta Vila de Angra dos Reis da Ilha Grande se } \\
\text { juntarão no Paço do Conselho os officiaes (...), e juntos todos } \\
\text { para fazerem vereança mandarão juntar os homens bons do } \\
\text { povo, e nela se acordarão mandarem chamar ao francez que } \\
\text { veio a terra dos navios francezes, que a este porto chegarão } \\
\text { para se Ihe perguntarem o que queriam: e chamado com } \\
\text { efeito à Conselho disse que o dito Francez, que El Rei da } \\
\text { França por queixas que El Rei de Portugal e El Rei de } \\
\text { Castella fizera, mandara quatro navios para estas partes para } \\
\text { limparem a costa dos Piratas que costumão roubas na Costas } \\
\text { nosas em embarcações (...). E pelos oficiaes da Câmara lhes }\end{array}$ \\
\hline
\end{tabular}




\begin{tabular}{|c|c|}
\hline & $\begin{array}{l}\text { foi dado porto a llha Grande (...) e mandarão que lhe } \\
\text { vendesem os moradores o que tivesem (...), que consta do } \\
\text { Livro dos Registros desta Câmara, do que fiz este termo, que } \\
\text { assinarão eu Guilherme do Vale Borralho Escrivão que os } \\
\text { escrevi (...)". }\end{array}$ \\
\hline $\begin{array}{l}\text { Livro dos Acord. } \\
\text { afs. } 147 \text { sobre } \\
\text { Quartel na Vila } \\
\text { de Angra dos } \\
\text { Reis. } \\
17 / 06 / 1699\end{array}$ & $\begin{array}{l}\text { "Em os quinze dias do mes de Março de } 1699 \text { anos nesta Vila } \\
\text { de Angra (...) se ajuntarão os vereadores e officiaes da } \\
\text { Câmara para fazerem vereança, e nela acordárão por um } \\
\text { Quartel pera dia de São Jozé dezanove de março se juntarem } \\
\text { os moradores na Vila para contar aos francezes que há gente } \\
\text { na terra que lhes possa resistir (...)". }\end{array}$ \\
\hline $\begin{array}{l}\text { Livro dos Acord. } \\
\text { afs. } 147 \text { sobre } \\
\text { náos francesas, } \\
\text { que vierão ao } \\
\text { Porto da Ilha } \\
\text { Grande. } \\
17 / 06 / 1699\end{array}$ & $\begin{array}{l}\text { "Em os dezasete dias do mez de junho de mil e seiscentos e } \\
\text { noventa e nove annos nesta Vila de Angra dos Reis (...) se } \\
\text { juntarão ao juiz Rafael da Silva Lagos, e os Vereadores } \\
\text { abaixo assinados para fazerem Vereança (...) e nela abriram } \\
\text { uma carta do General Arthur de Sá Menezes (...) em que } \\
\text { avizava de trez Náos Francezes que aparecião na Barra do } \\
\text { Rio de Janeiro e mandou que os Capitaens estivessem } \\
\text { arrumado sobre as armas com suas companhias para tudo o } \\
\text { que se oferecer (...). Acordarão". }\end{array}$ \\
\hline $\begin{array}{l}\text { Sobre os } \\
\text { Descaminhos do } \\
\text { ouro. } \\
27 / 09 / 1703\end{array}$ & $\begin{array}{l}\text { "Eu, El Rey faço saber aos que este meu Alvara em forma de } \\
\text { Ley virem (...) evitar os descaminhos quepode ter o ouro } \\
\text { produzido das Minas de São Paulo e os mais (...) descubertos } \\
\text { nas terras dos meus domínios e ser informado que as } \\
\text { embarcações que desta Capitania edas mais suas anexxas } \\
\text { sae a resgatar escravos a costa da Mina, a mayor } \\
\text { importância das suas carregações é ouro empó eem barras, e } \\
\text { que o negocio que avisão de fazer com os negros da costa, } \\
\text { levando para isso os gêneros costumados e fazem com os } \\
\text { estrangeiros que nelam andão a troco do mesmo ouro o que } \\
\text { por toda as rezões e circunstâncias é muitocontra minha } \\
\text { fazenda. Hey por bem deproibir absolutamente nem } \\
\text { daCapitania do Rio de Janeyro nem dos portos das } \\
\text { Capitanias do Sul possa ter embarcações algúa (...) Mando o } \\
\text { governador do Rio de Janeyro publicar esta Ley em todas as } \\
\text { partes que forem necessárias (...)". }\end{array}$ \\
\hline $\begin{array}{l}\text { Sobre o mandar- } \\
\text { se o Capitão de } \\
\text { Engenheiros à } \\
\text { Ilha Grande ver } \\
\text { se podia fazer } \\
\text { alguma } \\
\text { fortificação para } \\
\text { a defesa da Ilha. } \\
08 / 02 / 1704\end{array}$ & $\begin{array}{l}\text { "Senhor: Com os navios corsários que andam nesta costa e o } \\
\text { roubo que fizeram na sumaca dos açúcares da Ilha Grande, } \\
\text { mandei o capitão de Engenheiros ver se podia fazer alguma } \\
\text { fortificação para que defendesse as embarcações daquele } \\
\text { porto e impedisse o desembarque nele e me informa que } \\
\text { seria muito conveniente o fazer-se para este ministério, } \\
\text { porque estão expostos a tudo quanto quiserem fazer deles } \\
\text { qualquer embarcação que ali chegue; com esta notícia os } \\
\text { Vereadores e remeteram a carta que faço presente a V. M., } \\
\text { com a planta que fez o Engenheiro, para que sendo V.M. } \\
\text { servido ordenar que se faça, e se executar, enquanto não } \\
\text { tenho a resolução de Vossa Majestade, determino, se } \\
\text { aqueles moradores quiserem concorrer e mandar o } \\
\text { engenheiro fazê-la de faxina e por-lhe } 4 \text { peças que é o }\end{array}$ \\
\hline
\end{tabular}




\begin{tabular}{|c|c|}
\hline & $\begin{array}{l}\text { bastante para este intento, que para maior força não há } \\
\text { capacidade. Deus guarde a Real pessoa de Vossa } \\
\text { Majestade. Muitos anos como seus vassalos havemos } \\
\text { mister". }\end{array}$ \\
\hline $\begin{array}{l}\text { Resposta Rainha } \\
\text { da Grã-Bretanha } \\
\text { - infanta de } \\
\text { Portugal } \\
\text { 18/09/1704 }\end{array}$ & $\begin{array}{l}\text { "Dom Álvaro da Silveira e Albuquerque: Eu, a Rainha da Grã- } \\
\text { Bretanha, Infanta de Portugal vos envio muito saudar. } \\
\text { Havendo visto a conta que deste com a planta que } \\
\text { remetestes da fortificação que intentais fazer na Ilha Grande, } \\
\text { para a defesa dos piratas que costumam andar por aquele } \\
\text { porto fazendo as pilhagens que me dais notícia. Me pareceu } \\
\text { dizer-vos, que no que toca fazer-se a defensa da Vila de } \\
\text { Angra dos Reis que fica em terra firme de fronte da Ilha, é } \\
\text { muito acertado por ser uma vila a borda d'água, com porto } \\
\text { capaz de qualquer embarcação, porque ainda que a vila seja } \\
\text { pequena, será muito conveniente que esses poucos } \\
\text { moradores não estejam expostos a mercê de qualquer } \\
\text { corsário. E pelo que toca ao sítio assinalado na planta com a } \\
\text { letra P, se deve fazer quando o sítio não der lugar a outra } \\
\text { obra mais valente o que da planta não consta, por não trazer } \\
\text { petipé, e assim vos ordeno mandeis executar o dito reduto, e } \\
\text { quando se Ihe possa acomodar alguma defensa lateral será } \\
\text { melhor, para que tomareis o parecer do Sargento-Mor } \\
\text { Engenheiro José Paes Esteves. Escrito em Lisboa (...)". }\end{array}$ \\
\hline $\begin{array}{l}\text { Sobre france } \\
\text { na Vila de } A \\
\text { dos Reis } \\
07 / 06 / 1706\end{array}$ & $\begin{array}{l}\text { "Governador da Capitania Geral do Rio de Janeiro (...) vos } \\
\text { envio saudar (...) de dezembro do anno passado (...) de } \\
\text { alguns franceses queseacham moradores na Villa de Angra } \\
\text { dos Reis com filhos (...) em execução do que sobre aextinção } \\
\text { dos Estrangeiros (...). Deveis por em execução o que } \\
\text { avizastes de (...) minhas obras sobre estes franceses edoque } \\
\text { se refere neste particular medarei conta por toda cautella é } \\
\text { necessária (...). }\end{array}$ \\
\hline $\begin{array}{l}\text { Fortificação em } \\
\text { Paraty. } \\
11 / 06 / 1706\end{array}$ & $\begin{array}{l}\text { "Governador da Capitania Geral do Rio de Janeiro, Eu, El } \\
\text { Rey vos envio saudar (...) em resposta que com ela } \\
\text { remetestes dos officiais das Câmaras da Villa de Paraty e } \\
\text { Taubaté sobre a obra da fortificação de Paraty e repugnancia } \\
\text { que tem sobre concorrerem para a despesa da dita obra (...)" }\end{array}$ \\
\hline $\begin{array}{l}\text { Relação da } \\
\text { chegada da } \\
\text { Armada } \\
\text { Francesa a este } \\
\text { Rio de Janeiro. } \\
16 / 08 / 1710\end{array}$ & $\begin{array}{l}\text { "Em } 16 \text { do dito veio a notícia que uma nau do inimigo se } \\
\text { pusera de fronte da vila da llha Grande e a ficava } \\
\text { acanhoando com artilharia, e debaixo dela lhe botaram gente } \\
\text { em lanchas, as quais não chegaram a terra pela muita } \\
\text { mosquetaria que lhe atiraram os nossos das trincheiras que } \\
\text { tinham feito por todas as praias, ao que voltou o inimigo para } \\
\text { bordo de seu navio". }\end{array}$ \\
\hline $\begin{array}{l}\text { Carta do } \\
\text { Governador } \\
\text { Antônio Brito de } \\
\text { Meneses a } \\
\text { Tomás Gomes } \\
\text { da Guarnição de } \\
\text { Angra dos Reis }\end{array}$ & $\begin{array}{l}\text { "Porque é certa notícia que Ihes mandei que o navio vinha } \\
\text { carregado por Laborda (...), haverá gente que o avise e } \\
\text { embargará a ordem que leva o Capitão-de-Mar-e-Guerra que } \\
\text { o aprisionou e, para que consiga essa diligência com bom } \\
\text { feito, mandará a V. Mercê ter uma vigia na Ponta da Ilha } \\
\text { Grande que melhor descobrir o mar todo o dia e ver algum } \\
\text { navio que ocorre no longo da costa ou venha buscar a terra }\end{array}$ \\
\hline
\end{tabular}




\begin{tabular}{|c|c|}
\hline $\begin{array}{l}\text { sobre a ação dos } \\
\text { piratas na Ilha } \\
\text { Grande. } \\
\text { 26/02/1718 }\end{array}$ & $\begin{array}{l}\text { com uma bandeira holandesa no topo da proa lhe } \\
\text { responderem em terra com uma bandeira branca, deixando } \\
\text { esta até eles por as capas, e V. Mercê estará prevenido com } \\
\text { uma lancha para ir buscar o Ihe dar notícia que tiver } \\
\text { advertindo que há de levar o prático que tiver melhor, e que a } \\
\text { lancha com a gente que levar há de acompanhar o navio para } \\
\text { Ihe descobrir as enseadas e só virá por V. Mercê em terra e } \\
\text { voltará de sorte que não falem com ninguém (...)'. }\end{array}$ \\
\hline $\begin{array}{l}\text { Translado da } \\
\text { Patente do } \\
\text { Coronel } \\
\text { Lourenço } \\
\text { Carvalho da } \\
\text { Cunnha. Reg. } \\
\text { afs. } 173 \text {. } \\
01 / 10 / 1719\end{array}$ & $\begin{array}{l}\text { "Ayres de Saldanha Alburquerque (...). Faço saber ao que } \\
\text { esta minha carta patente virem que atendendo a } \\
\text { reprezentarme os ofeciais da Câmara da Vila de Angra dos } \\
\text { Reis (...) acharemse nella e em seus destrito quatro } \\
\text { Companhias de Ordenansa sem oficial mayor que as } \\
\text { Governe e Constandome também haver na mesma forma } \\
\text { duas em Paraty e huma Obatuba e ser conveniente ao } \\
\text { cerviso de sua Magestade (...) nomearlhe oficiaes mayores } \\
\text { pessoas de toda satisfasão para as terem deseplinadas e ser } \\
\text { informado que na de Lourenço Carvalho da Cunha concorrem } \\
\text { requizitos necessários no anno de } 711 \text { na ocazião que o } \\
\text { inemigo impedio esta prasa achandose uma Nao de forsa } \\
\text { combatendo a Villa (...) acudio prontamente com todos os } \\
\text { seus Escravos e mais familiares armados e municiados a } \\
\text { fazer trinxeiras com madeiras que conduzio dispondo de tal } \\
\text { sorte a defensa della que inemigo se não atreveu a Cometella } \\
\text { (...) e no mesmo anno hindo a villa de Paraty o capitão de } \\
\text { Innfantaria paga Francisco de Seixas do Bujar qualquer } \\
\text { danno que os corsarios francezes intentassem fazer na ditta } \\
\text { Villa acudir logo com muito Escravos ajundando com elles a } \\
\text { fazer trinxeiras e sendo necessário mandar socorro a Ilha } \\
\text { Grande oitenta homens por estar o enemigo sobre ella dava } \\
\text { suas embarcasoens para outro no Porto de Gente (...). Hey } \\
\text { por bem fazer mercê (...) ao ditto Lourenço Carvalho da } \\
\text { Cunha de o prover no posto de Coronel da gente da ordenasa } \\
\text { da Villa de Angra dos Reis da Ilha Grande e Paraty (...)". }\end{array}$ \\
\hline $\begin{array}{l}\text { Sobre Paraty e } \\
\text { Ilha Grande. } \\
03 / 07 / 1725\end{array}$ & $\begin{array}{l}\text { "Entre a Ilha Grande está um porto onde os navios } \\
\text { estrangeiros dão fundo a fim de negócios...De fronte a ilha } \\
\text { estão duas vilas: a de Angra dos Reis (sob a jurisdição do } \\
\text { Rio) e a de Paraty (São Paulo)...Paraty é distante de São } \\
\text { Paulo. Ficando deste modo exposto o governo do RJ a } \\
\text { prática de negócios com estrangeiros...O governador pede } \\
\text { que somente um governo tome conta das duas vilas e da llha } \\
\text { Grande". }\end{array}$ \\
\hline $\begin{array}{l}\text { Regimento sobre } \\
\text { os navios } \\
\text { estrangeiros. } \\
08 / 11 / 1725\end{array}$ & $\begin{array}{l}\text { "Primeiramente (...) he proibido o comércio com os } \\
\text { estrangeiros em todos os portos e costas da América (...) que } \\
\text { chegando algum navio estrangeiro aos ditos portos com } \\
\text { urgentíssima necessidade sejam socorridos, sugeitando-se o } \\
\text { exame della, debaixo de artilharia de algua fortaleza para } \\
\text { serem confiscados, no caso que se julgue affectado, ou } \\
\text { suspeitozo a sua arribada (...). E porque nada do referido se } \\
\text { pode executar na Villa de Angra dos Reis assim por não }\end{array}$ \\
\hline
\end{tabular}




\begin{tabular}{|c|c|}
\hline & 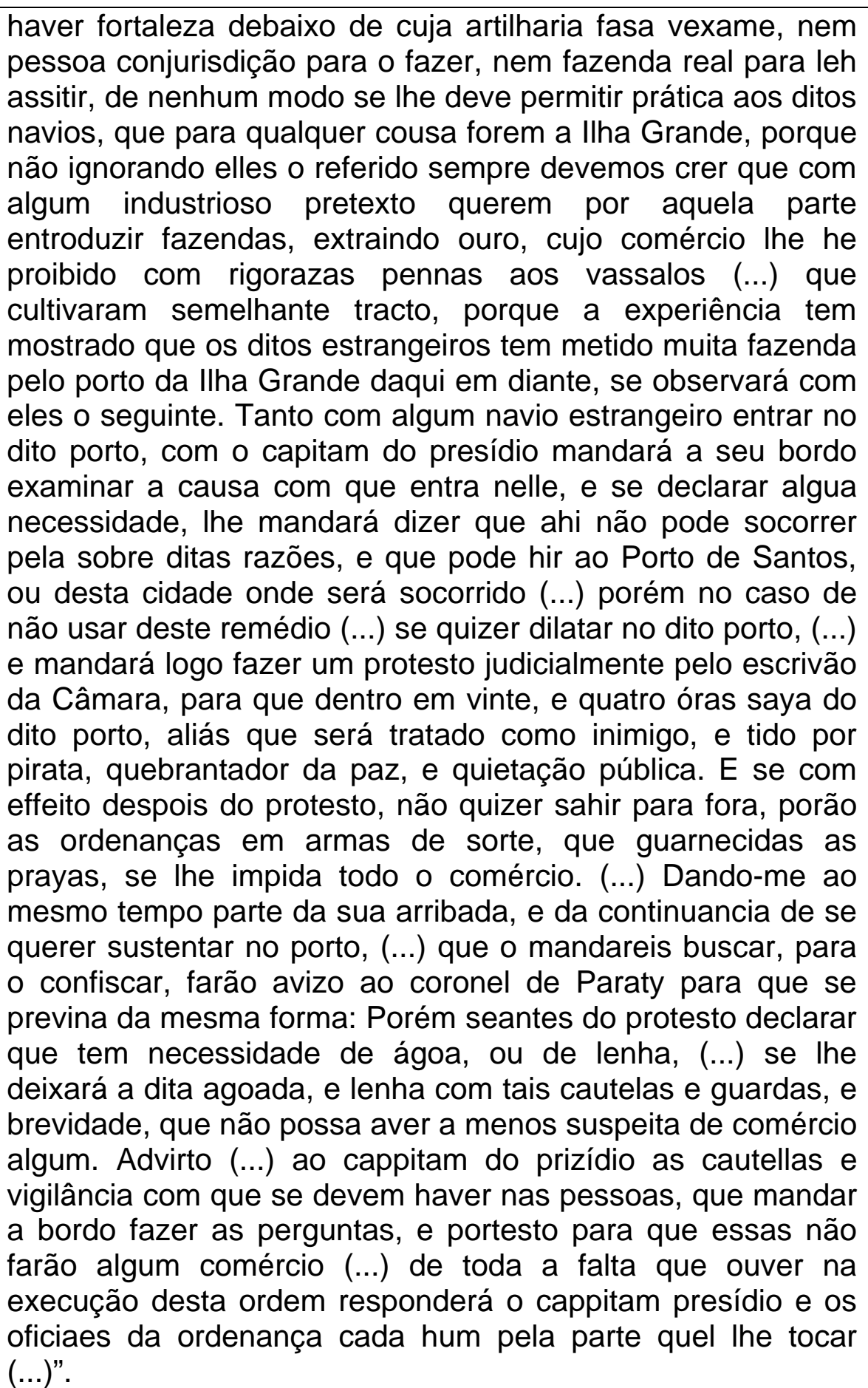 \\
\hline $\begin{array}{l}\text { Para o secretário } \\
\text { de Estado pella } \\
\text { Bahya sobre o } \\
\text { Navio Dom } \\
\text { Carlos e } \\
\text { asustatoria dos } \\
\text { frades. } \\
17 / 10 / 1725\end{array}$ & $\begin{array}{l}\text { Em dezembro de } 1724 \text { arribaram na Ilha Grande três navios } \\
\text { holandeses..além disso...arribou no RJ um Pataxe chamado } \\
\text { Mercúrio e um navio chamado D. Carlos da mesma } \\
\text { conserva..comandado por Pedro Gleisem...o governador } \\
\text { mandou prover o navio de tudo que era necessário..depois o } \\
\text { fez sair deste porto...na condição de que não fosse a Ilha } \\
\text { Grande, porque ali o mandaria tratar com toda a hostilidade, } \\
\text { mas ele foi a dita Ilha..O Capitão do presídio estava } \\
\text { prevenido...mandei Jozefh Soares de Andrade, comandante } \\
\text { da guarda-costa, para que fosse buscá-lo...esteve o holandês } \\
\text { em condições de combate...mas ao ver que seria atacado pela }\end{array}$ \\
\hline
\end{tabular}




\begin{tabular}{|c|c|}
\hline & $\begin{array}{l}\text { fragata e por lanchas armadas com gente da terra se rendeu } \\
\text { e voltou ao RJ...foi mandado para Bahia. (Navios vinham a } \\
\text { fazer na América negócios de contrabando - 17/03/1726) }\end{array}$ \\
\hline $\begin{array}{l}\text { Sobre assistir } \\
500 \text { mil réis para } \\
\text { se fazerem } \\
\text { quartéis na Ilha } \\
\text { Grande. } \\
\text { 26/01/1726 }\end{array}$ & $\begin{array}{l}\text { (...) Faço saber a vós Luis Vahia Monteiro (...) que havendo } \\
\text { visto o que informou vosso antecessor em carta de nove de } \\
\text { setembro do ano passado sobre a representação que me } \\
\text { fizeram os oficiais da Câmara da Ilha Grande, em que me } \\
\text { pedem uma ajuda de custo para acudirem os quartéis do } \\
\text { Capitão, Alferes e soldados que guarnecem aquela praça e } \\
\text { que fosse conservado no dito Presídio (praça fortificada) o } \\
\text { capitão de infantaria Eusébio S. Leitão (...). Me pareceu que } \\
\text { eu darei por resolução minha de } 26 \text { deste presente mês e ano } \\
\text { em consulta do meu conselho ultramarino } 500 \text { mil réis pela } \\
\text { minha real fazenda para esta obra (...) e no que respeita a } \\
\text { assistência do dito capitão por tempo de três anos não sou } \\
\text { servido deferir-lhe pelos muitos inconvenientes que nesta } \\
\text { presente se consideram. }\end{array}$ \\
\hline $\begin{array}{l}\text { Pelo Conselho- } \\
\text { sobre o Navio D. } \\
\text { Carlos. } \\
17 / 03 / 1726\end{array}$ & $\begin{array}{l}\text { 20/05/1725 - Pataxe Mercúrio - Ilha Grande - revendido no } \\
\text { RJ..30/05/1725 - Navio Dom Carlos - saiu do Porto em } 2 \text { de } \\
\text { agosto para que não fosse a Ilha Grande. Nesse sentido, o } \\
\text { governador mandou dobrar o Presídio da Ilha Grande, } \\
\text { ordenando ao capitão dele muito vigilância...e com } \\
\text { efeito..saiu do RJ e foi na direção da Ilha Grande, chegou a } \\
\text { boca da barra, onde chamam Marambaia, distante mais de } \\
\text { quatro léguas de Angra dos Reis, onde está o presídio..sem } \\
\text { participar ao capitão do dito presídio a sua chegada..sabendo } \\
\text { que ali havia guarnição..por ter estado naquele porto em } \\
\text { dezembro de } 1724 . . \text { Ordenei ao juiz da Vila de Angra dos Reis } \\
\text { que fizesse um sumário do que lá constasse e mandei que o } \\
\text { comandante da guarda-costa fosse buscar o navio..voltou ao } \\
\text { RJ em } 14 / 08 . . . \text { fez o exame de costume e anexou o sumário } \\
\text { feito em Angra dos Reis. }\end{array}$ \\
\hline $\begin{array}{l}\text { Resposta de Luis } \\
\text { Vahia Monteiro } \\
16 / 07 / 1726\end{array}$ & $\begin{array}{l}\text { Fico entendendo o que Vossa Majestade me ordena de } \\
\text { entregar } 500 \text { mil réis para se acudir os quartéis da llha } \\
\text { Grande, e determino sendo-me possível chegar a ela para } \\
\text { resolver o Engenheiro o conserto da obra, de sorte que não } \\
\text { se gaste este dinheiro inutilmente. }\end{array}$ \\
\hline $\begin{array}{l}\text { Sobre as } \\
\text { arribadas dos } \\
\text { Navios Dom } \\
\text { Carlos, Mercúrio, } \\
\text { Bejamin, e } \\
\text { Aurora, de que } \\
\text { se remetem os } \\
\text { autos. } \\
06 / 07 / 1726\end{array}$ & $\begin{array}{l}\text { Em } 17 \text { de março deste ano dei conta a Vossa Majestade pela } \\
\text { via das Ilhas sobre a arribada que aqui fez o navio holandês } \\
\text { chamado Dom Carlos de que é capitão Pedro Gleicem, } \\
\text { mandando por cópia os autos. Agora remeto os próprios com } \\
\text { a cópia da carta que naquela ocasião acompanhou as cópias, } \\
\text { e se me oferece mais dizer a Vossa Majestade que com eles } \\
\text { remeto preso a Pedro Hoqueman pessoa inquieta, e } \\
\text { certamente prejudicialismo nesta capitania ao serviço de } \\
\text { Vossa Majestade pelo que respeita aos interesses dos } \\
\text { estrangeiros, de que procede, e dos quais se criou, e ainda } \\
\text { que diz ser natural dessa Corte e casado nela. Estou certo } \\
\text { que chegando aqui o dito Capitão Pedro Gleisem se } \\
\text { acomodaria com assistência, de que necessitava para seguir }\end{array}$ \\
\hline
\end{tabular}




\begin{tabular}{|c|c|}
\hline & $\begin{array}{l}\text { sua viagem, mas este homem lhe meteu tais coisas na } \\
\text { cabeça ensinando-lhe a fazer requerimentos impertinentes, a } \\
\text { fim de se dilatar neste que com ele me fez uma grande } \\
\text { pertubação, eultimamente depois que o seqüestrei pela } \\
\text { arribada da Ilha Grande se meteu a seu procurador como } \\
\text { consta do auto incluso que mandei fazer ao ouvidor (...)". }\end{array}$ \\
\hline $\begin{array}{l}\text { Sobre fortificar a } \\
\text { Vila de Angra } \\
\text { dos Reis da Ilha } \\
\text { Grande e vila de } \\
\text { Paraty } \\
07 / 11 / 1726\end{array}$ & 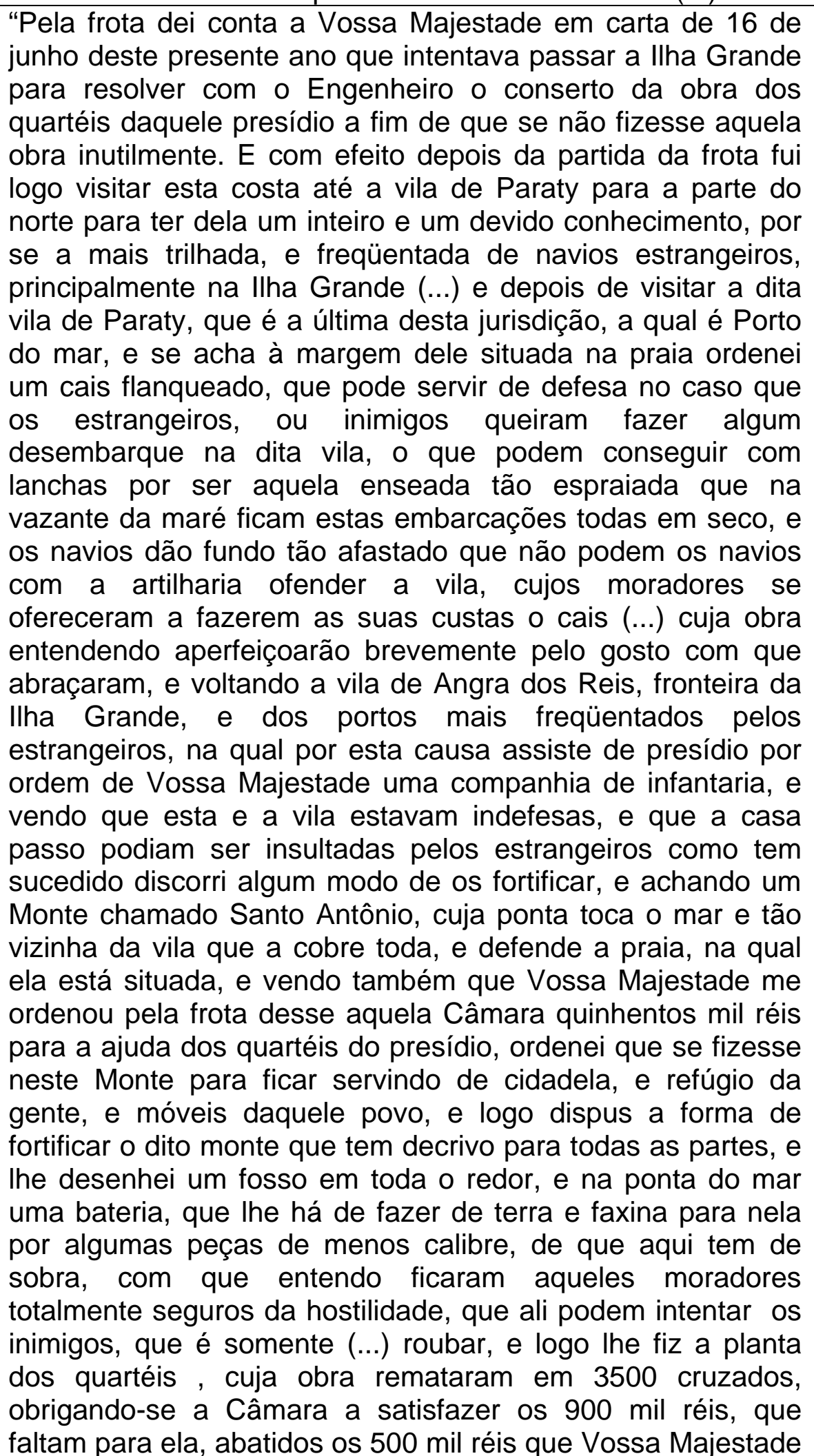 \\
\hline
\end{tabular}




\begin{tabular}{|c|c|}
\hline & $\begin{array}{l}\text { me manda dar e toda obra mais se faz a custa dos } \\
\text { moradores, sendo a Câmara e todos os mais principais os } \\
\text { primeiros a se oferecerem a fazer o fosso, o qual lhe deixei } \\
\text { logo repartido, dando a cada um uma tarefa, que pediu } \\
\text { conforme a posse de cada um, e negros que tinham e na } \\
\text { verdade me edificou o selo (zelo) que estes moradores } \\
\text { mostraram que estes moradores mostraram ao serviço de V. } \\
\text { M. pelo gosto e amor com que se aplicam a esta obra, que } \\
\text { espero daqui a um ano em termos de lhe por em artilharia, o } \\
\text { que executarei sem esperar nova ordem, assim pela } \\
\text { necessidade como por achar uma de } 190 \text { de novembro de } \\
\text { 1712em que vossa Majestade manda fortificar aquela vila } \\
\text { podo-Ihe artilharia, no que até agora não se cuidou." }\end{array}$ \\
\hline $\begin{array}{l}\text { Sobre o } \\
\text { requerimento da } \\
\text { Câmara da Ilha } \\
\text { Grande que pede } \\
\text { os privilégios que } \\
\text { tem os desta } \\
\text { cidade. } \\
14 / 11 / 1726\end{array}$ & $\begin{array}{l}\text { "Dom João por graças de Deus rei de Portugal (...). Faço } \\
\text { saber a vós Luís Vahia Monteiro que os oficiais da Câmara da } \\
\text { vila de Angra dos Reis me representaram na carta, cuja cópia } \\
\text { com esta se vos remete assinada pelo secretário do meu } \\
\text { conselho ultramarino o grande zelo, e fidelidade com que se } \\
\text { tem havido em meu real serviço na defesa daquela praça } \\
\text { sendo por várias vezes invadida por estrangeiros portanto me } \\
\text { pediam, que aos que tem servido com este procedimento no } \\
\text { dito Senado se lhe conceda os mesmos privilégios que tem } \\
\text { os cidadãos desta cidade. Me pareceu ordenarvos informeis } \\
\text { com vosso parecer (...)". }\end{array}$ \\
\hline $\begin{array}{l}\text { Resposta de Luiz } \\
\text { Vahia Monteiro. } \\
\text { 06/07/1727 }\end{array}$ & $\begin{array}{l}\text { "Tudo o que a Vila de Angra dos Reis da Ilha Grande } \\
\text { representa a Vossa Majestade é verdade sem encarecimento, } \\
\text { e ainda lhe falta por dizer a fortificação de uma cidadela, que } \\
\text { estão fazendo a sua custa, ainda que de terra e faxina, muito } \\
\text { defensável, edificando juntamente nela uns quartéis para a } \\
\text { infantaria que ali assiste o Presídio, que Ihe custam } 4 \text { mil } \\
\text { cruzados para ajuda dos quais foi V. M. servido mandar-Ihe } \\
\text { dar } 500 \text { mil réis como dei conta em carta a V.M. em } 07 \text { de } \\
\text { setembro de } 1726 \text { e em tudo o mais que se oferece do } \\
\text { serviço de V.M. tendo experimentado naquela Câmara, um } \\
\text { eficaz zelo e costumando haver em todas as mais vilas } \\
\text { semelhantes aquela vários distúrbios, bastou uma carta } \\
\text { porque os adverti com suavidade para cessar tudo e não ter } \\
\text { em todo o tipo do meu Governo senão motivo de Ihe dar } \\
\text { muitos agradecimentos por cujos serviços discorro que } \\
\text { igualmente merecem os privilégios que pedem (...)." }\end{array}$ \\
\hline $\begin{array}{l}\text { Sobre o ofício do } \\
\text { Provedor do } \\
\text { Registro da Vila } \\
\text { de Paraty. } \\
31 / 07 / 1727\end{array}$ & $\begin{array}{l}\text { "Quando o ano passado fui visitar esta costa, para a parte do } \\
\text { sul dei conta a Vossa Majestade, chegando a vila de Paraty, } \\
\text { incorporada a.....governo de São Paulo achei nela o coronel } \\
\text { Manuel Dias de A...nomeado por aquele governo Provedor do } \\
\text { Regimento, mas este sem e......algum porque não tinha } \\
\text { escrivão, nem havia providencia alguma p....os descaminhos } \\
\text { do ouro porque aquele caminho chamado velho v...minas } \\
\text { gerais e de São Paulo pelas vilas de Taubaté e } \\
\text { Guaratinguetá, conhecendo no dito coronel todas as } \\
\text { circunstâncias de zelo e inteligência mandei continuar na }\end{array}$ \\
\hline
\end{tabular}




\begin{tabular}{|c|c|}
\hline & mesma ocupação (...)". \\
\hline $\begin{array}{l}\text { Noveau Voyage } \\
\text { Antorir du } \\
\text { Monde, Le Gentil } \\
\text { Labarbinais } \\
1728\end{array}$ & $\begin{array}{l}\text { "Do mar vieram os primeiros exploradores da costa (...) dele } \\
\text { vinham os corsários em busca de água, lenha, comida, ouro, } \\
\text { vingança (...). A Ilha Grande é o único lugar onde os } \\
\text { portugueses suportam a presença estrangeira, porque lá eles } \\
\text { não têm condições de persegui-los (...)". }\end{array}$ \\
\hline $\begin{array}{l}\text { Ofício de Luís } \\
\text { Vahia Monteiro } \\
\text { ao alferes João } \\
\text { da Costa, } \\
\text { comandante da } \\
\text { Fortaleza do } \\
\text { Carmo. } \\
\text { 02/05/1732 }\end{array}$ & $\begin{array}{l}\text { "Sobre a morte da vaca tem vossa mercê feito alguns } \\
\text { depósitos porque suposta a levaria matar, segundo a ordem } \\
\text { que deixei para não andarem na fortaleza, não a deveria } \\
\text { deixar comer aos Soldados ao que se cometeu roubo, antes, } \\
\text { deveria mandar dar parte ao Convento, para que } \\
\text { aproveitasse se quisesse; à vista de que mandará logo } \\
\text { satisfazer o seu valor, ou comprar outra para entregar ao } \\
\text { Convento e o Alcaide mandará soltar em vista desta, sem } \\
\text { embargo de ser preso se acaso fazia a diligência na fortaleza } \\
\text { sem lhe dar parte, a advertindo que passagem da vila para } \\
\text { outra banda, pela bateria da artilharia, não se pode impedir } \\
\text { de dia, nem de noite, enquanto não estiver toda a obra } \\
\text { acabada". }\end{array}$ \\
\hline $\begin{array}{l}\text { Ofício de Luís } \\
\text { Vahia Monteiro } \\
\text { ao Frei Manoel } \\
\text { de São Roque, } \\
\text { guardião do } \\
\text { primeiro } \\
\text { Convento de São } \\
\text { Bernardino. } \\
\text { 20/05/1732 }\end{array}$ & $\begin{array}{l}\text { "Sinto que o primeiro raio caísse na rês desse Convento, } \\
\text { ainda que foi bem morta pelos despresos com que se olha } \\
\text { para as coisas de El-Rei e minhas ordens, pois, foram bem } \\
\text { publicas para que o gado não fosse as obras daquela } \\
\text { fortaleza, mandando avisar para que os donos pusessem } \\
\text { pastor; mas foi muito mal comida pelos Soldados e por esta } \\
\text { causa ordenou ao Alferes que logo a mande pagar ao } \\
\text { Convento ou entregar outra vaca melhor, e sobre este ponto } \\
\text { da comida da vaca teria com as Varas outro procedimento se } \\
\text { não me atalhasse o acelerado muito de Justiça, que Vossa } \\
\text { Paternidade usou e as arrogância dos religiosos que foram à } \\
\text { Fortaleza de que estou informado pelo Alferes mais todas } \\
\text { pessoas que vem dessa vila, que ouviram as vozes, e isto é o } \\
\text { que me tem mais admirado, achando-se Vossa Paternidade } \\
\text { por Guardião desse Convento, de cujas virtudes, esperava } \\
\text { eu, outros efeitos, mais estes os atribuiu as arrogâncias que } \\
\text { produziram em muitos religiosos as discórdias que tiveram } \\
\text { entre si (...)'. }\end{array}$ \\
\hline $\begin{array}{l}\text { Cópia da Carta } \\
\text { que os officiaes } \\
\text { da Câmara } \\
\text { escreverão a } \\
\text { Sua Magestade. } \\
\text { Anno de } 1737\end{array}$ & $\begin{array}{l}\text { "(...) Este povo não obstante sua muita penúria que tem feito } \\
\text { a Vossa Real Magestade o asás util serviço alem de outro de } \\
\text { fortificar esta villa com hum forte acompanhado de boas } \\
\text { cazas para se aquartellarem todos os militares, que a ella } \\
\text { venhão de guarnição (...)". }\end{array}$ \\
\hline $\begin{array}{l}\text { Relato de uma } \\
\text { inspeção do } \\
\text { Sargento-Mor } \\
\text { Joaquim Correa } \\
\text { da Serra, a } \\
\text { mando do }\end{array}$ & $\begin{array}{l}\text { "Desta diligência seguiu-se alargar-se mais o terreno da } \\
\text { praça, que há no Forte de Nossa Senhora do Carmo sito na } \\
\text { Terra Firme ao nascente da Vila de Angra dos Reis, e fazer- } \\
\text { se um entrincheiramento abarbela. Também se delineou um } \\
\text { ângulo reentrante da parte esquerda daquela fortificação, por } \\
\text { se julgar a propósito para defender o saco, que naquela parte }\end{array}$ \\
\hline
\end{tabular}




\begin{tabular}{|c|c|}
\hline $\begin{array}{l}\text { governo colonial } \\
\text { das defesas da } \\
\text { Ilha Grande, } \\
\text { Paraty, em } 1793, \\
\text { com ordens para } \\
\text { fazer obras, se } \\
\text { necessário. } \\
1793\end{array}$ & 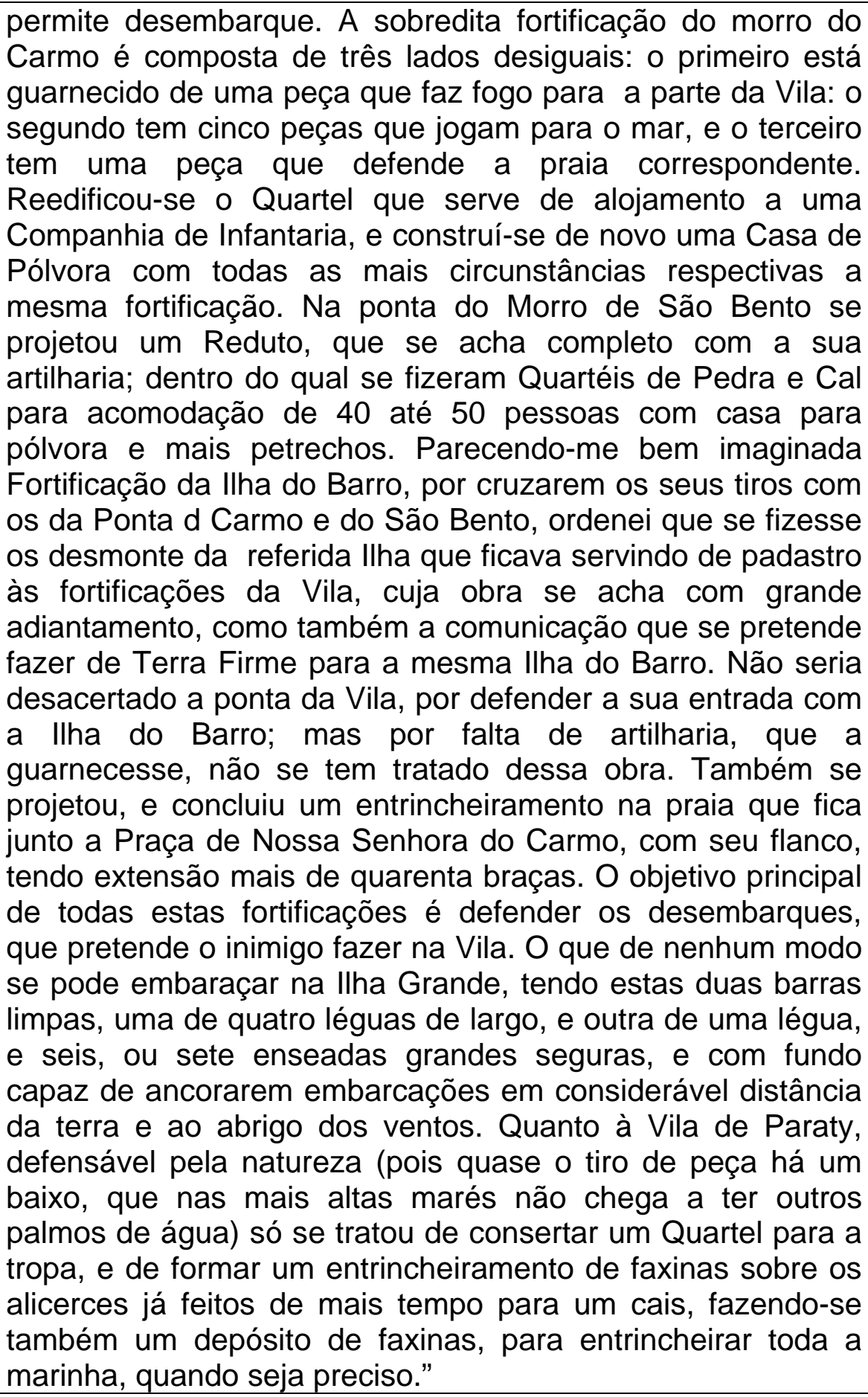 \\
\hline $\begin{array}{l}\text { Estado das } \\
\text { fortificações em } \\
\text { Nossa Senhora } \\
\text { da Conceição de } \\
\text { Angra dos Reis } \\
\text { da llha Grande e } \\
\text { Nossa Senhora } \\
\text { dos Remédios } \\
\text { em Paraty.1797 }\end{array}$ & $\begin{array}{l}\text { "Ilmo e Exmo. Senhor Conde Vice-Rey } \\
\text { O coronel ajudante de ordens Gaspar José de Matos, esta } \\
\text { manhã me intimou que Vossa Excelência me ordenava o } \\
\text { informar-se do estado atual das fortificações das villas de } \\
\text { Paraty e Ilha Grande, Coma também das despesas que se } \\
\text { tem feito, e do dinheiro que existe, e se havia ou não algumas } \\
\text { pessoas que quisessem ser oficiais do cais (...). Quartel do } \\
\text { Campo de Santana". Pedro Álvares de Andrade }\end{array}$ \\
\hline $\begin{array}{l}\text { Carta Enviada ao } \\
\text { Vice-Rey por }\end{array}$ & O Forte de São J \\
\hline
\end{tabular}




\begin{tabular}{|c|c|}
\hline $\begin{array}{l}\text { Pedro Álvares de } \\
\text { Andrade. } \\
\text { 16/03/1797 }\end{array}$ & 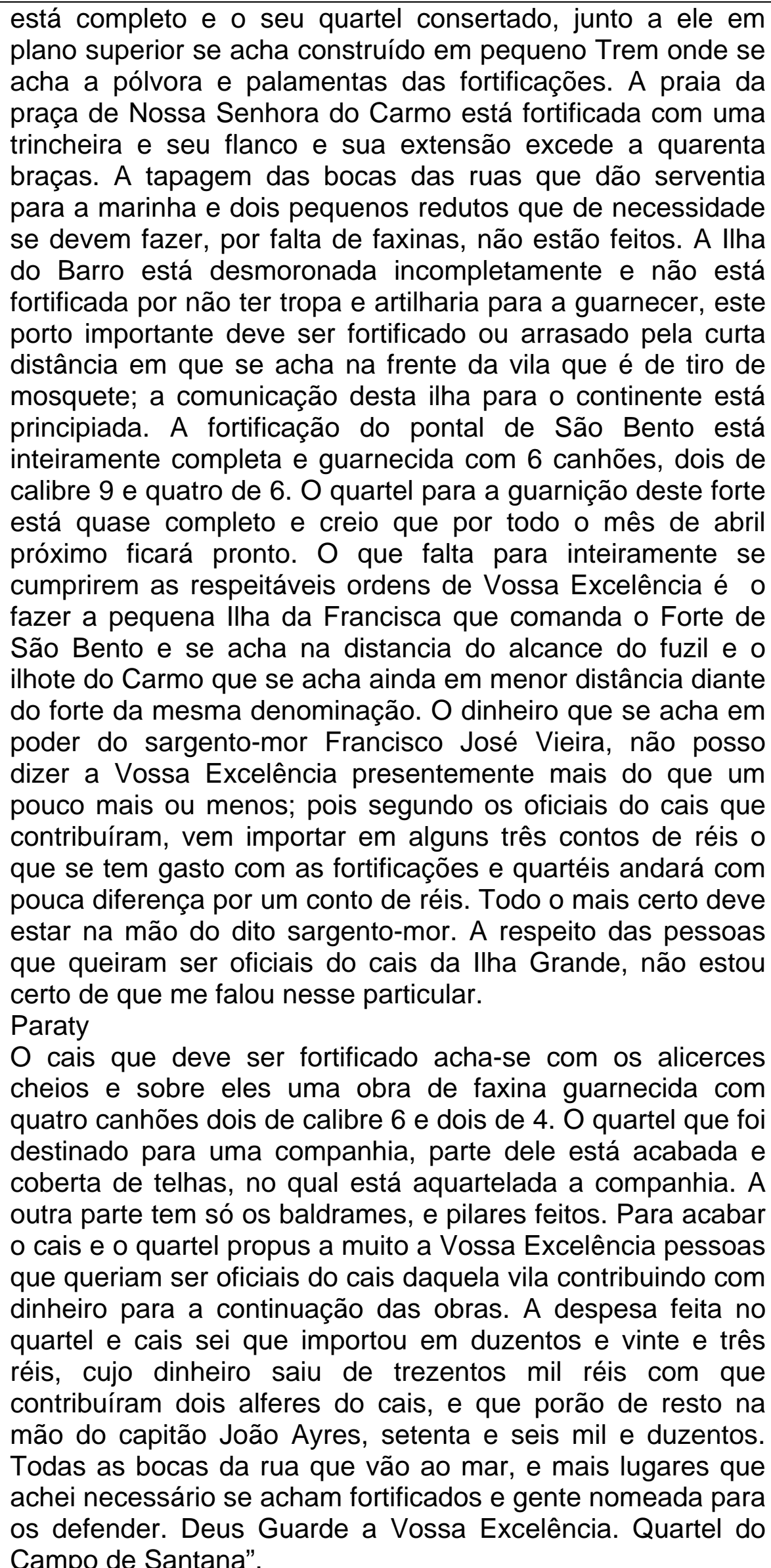 \\
\hline
\end{tabular}




\begin{tabular}{|c|c|}
\hline $\begin{array}{l}\text { Registo da Carta } \\
\text { de Offício do } \\
\text { Governador } \\
\text { Militar Manoel } \\
\text { Joaquim Pereira. } \\
\text { 08/09/1822 }\end{array}$ & $\begin{array}{l}\text { “(...) Manda o Príncipe Regente pela Secretaria de Estado } \\
\text { dos Negócios da Guerra, participar o Brigadeiro Manoel } \\
\text { Joaquim da Silva, que he por bem dispens-alo do destino que } \\
\text { lhe dera de Commandante das Armas da Província de Santa } \\
\text { Catharina para continuar o Governo Militar de Ilha Grande e } \\
\text { Paraty, ficando assim de nenhum effeito a nomeação do } \\
\text { Brigadeiro de Engenheiros Antônio José Rodrigues e por } \\
\text { tanto ordena que sem perda de tempo marche para o } \\
\text { governo dos mencionados Districtos em cuja defesa deverá } \\
\text { empregar a maior actividade, vigilancia e zelo que o } \\
\text { caracteriza (...)". }\end{array}$ \\
\hline $\begin{array}{l}\text { Defesa de Angra } \\
\text { dos Reis e } \\
\text { Paraty a respeito } \\
\text { dos piratas. } \\
14 / 02 / 1826\end{array}$ & $\begin{array}{l}\text { "(...) Com a chegada a este Vila fez ver a alguns habitantes a } \\
\text { grande necessidade que havia pelo menos de uma barca } \\
\text { canhoneira, que não só fizesse este porto mais respeitável, } \\
\text { como servisse de socorro aos diferentes lavradores, que se } \\
\text { acham com suas propriedades à beira-mar, e por isso mesmo } \\
\text { mais expostos aos insultos de qualquer corsário, ou pirata. } \\
\text { Esta medida é tão necessária que a experiência mostrou em } \\
1801 \text {, um pequeno corsário espanhol fez prisioneiro a sete } \\
\text { embarcações deste porto, e Paraty que se achavam } \\
\text { fundeadas nas Palmas, algumas léguas distantes desta vila, } \\
\text { à espera de monção sem lhes poder prestar socorros, que } \\
\text { muito aproveitariam, ainda sendo pequenos. Fazendo ver aos } \\
\text { habitantes s dificuldades que havia de se não poderem } \\
\text { presentemente construir no Arsenal da Marinha: a minha } \\
\text { exposição foi muito bem recebida por aquelas pessoas a } \\
\text { quem num pequeno espaço de tempo pude comunicar e } \\
\text { todas estão prontas a prestarem-se cada uma como for } \\
\text { compatível com seus teres, e por isso desde já espero o } \\
\text { melhor resultado, ainda quando não seja senão para as } \\
\text { madeiras, e mão-de-obra. Para melhor das princípio ao } \\
\text { apresto das mesmas madeiras, sirva-se Vossa Excelência, } \\
\text { merecendo a Imperial Aprovação de S. M. o Imperador, } \\
\text { ordenar que o (...) Inspetor da Marinha me remeta quanto } \\
\text { antes os moldes, que se acham feitos de tais barcas, para } \\
\text { desde já por em prática os referidos cortes (...). Vila da Ilha } \\
\text { Grande. Manoel Joaquim Pereira da Silva. Governador } \\
\text { Militar". }\end{array}$ \\
\hline $\begin{array}{l}\text { Defesa de Angra } \\
\text { dos Reis e } \\
\text { Paraty a respeito } \\
\text { dos piratas. } \\
01 / 04 / 1826\end{array}$ & $\begin{array}{l}\text { "Depois de } 17 \text { principiados no último de fevereiro, de um } \\
\text { grande ataque de febres (...) que esteve a minha vida (...), } \\
\text { não pude por em prática a importante comissão de que Vossa } \\
\text { Excelência foi servido encarregar-me, mas que brevemente } \\
\text { pretendo principiar (...). Já recebi as formas e algumas } \\
\text { instruções para os cortes da madeiras, por todo este mês } \\
\text { pretendo-me achar restabelecido e dar princípio (...). Manoel } \\
\text { Joaquim Pereira da Silva. Governador Militar". }\end{array}$ \\
\hline $\begin{array}{l}\text { Embarcações } \\
\text { aprisionadas. } \\
13 / 11 / 1826\end{array}$ & $\begin{array}{l}\text { "Levo ao conhecimento de V. Ex.a. que achando-me no dia } \\
10 \text { do corrente em Maria Albarda na llha Grande de Fora, (...) } \\
\text { pelas } 5 \text { horas da tarde chegaram no proto da Freguesia duas }\end{array}$ \\
\hline
\end{tabular}




\begin{tabular}{|c|c|}
\hline & $\begin{array}{l}\text { canoas, uma com dois homens e outra com três, eram } \\
\text { mandados com ofícios à Corte, e a saber o que conduziam os } \\
\text { dois eram mandados pelo comércio para obstarem as } \\
\text { embarcações que se acham, porque no dia } 6 \text {, entrando na } \\
\text { barra da mesma vila } 3 \text { embarcações vindas da Corte foram } \\
\text { tomadas por um navio, e nessa mesma ocasião saindo duas } \\
\text { da dita vila, que se dirigiam para a Corte uma foi logo tomada, } \\
\text { e a outra por desconfiança que teve deu fundo debaixo da } \\
\text { Fortaleza de Santa Cruz (...) e que nem por isso deixou de } \\
\text { ser tomada, porque pelas } 6 \text { horas da tarde a vieram conduzir, } \\
\text { cortando-Ihe as amarras e a levaram, e que o Governador } \\
\text { daquela Fortaleza mandara embarcar um destacamento e } \\
\text { foram em seu seguimento, e que já era alta noite quando o } \\
\text { Governador deu parte ao Governo da praça (...) e saíram } \\
\text { então tropas da praça mandadas pelo governo em lanchões } \\
\text { guarnecidos (...) para irem retomar as embarcações } \\
\text { prisioneiras que ainda se avistavam, além da embarcação } \\
\text { inimiga, via-se outra maior muito longe (...). José Joaquim de } \\
\text { Almeida. Ajudante." }\end{array}$ \\
\hline $\begin{array}{l}\text { Sobre corsários } \\
\text { na Vila de } \\
\text { Paraty. } \\
13 / 11 / 1826\end{array}$ & $\begin{array}{l}\text { "Agora pelas dez horas da noite recebo parte pelo Tenente } \\
\text { Comandante do Destacamento das Palmas ter aí aparecido } \\
\text { uma escuna corsário pelas quatro horas e meia da tarde com } \\
\text { a bandeira imperial, e ali aprisionou três pequenas } \\
\text { embarcações da Vila de Paraty, diz o mesmo comandante } \\
\text { que fizera alguns roubos, o que não puderam obstar por falta } \\
\text { de gente, diz mais o portador que trouxe a parte, que dera } \\
\text { caça a dois barcos que vinham do Rio para esta vila, os quais } \\
\text { não puderam conseguir. Neste mesmo instante faço partir um } \\
\text { destacamento de trinta homens comandados pelo Capitão de } \\
\text { artilharia de linha, munidos de pólvora, bala e armamento a } \\
\text { ver se poderá conseguir a retomada de algum dos ditos } \\
\text { barcos (...). Manoel Joaquim Pereira da Silva. Governador } \\
\text { Militar." }\end{array}$ \\
\hline $\begin{array}{l}\text { Registo do } \\
\text { Offício, q'esta } \\
\text { Câmara de } \\
\text { Paraty dirigio ao } \\
\text { Governador } \\
\text { Militar desta Vila } \\
\text { da Ilha Grande. } \\
\text { 27/11/1826 }\end{array}$ & $\begin{array}{l}\text { "(...). Para satisfazer ao clamor geral do Povo que se queixa } \\
\text { de falta de providencias para a Segurança e defeza d'esta } \\
\text { Villa, pois que os vigias não enchem o fim, para que se } \\
\text { estabelecerão e athé abandonão os seus postos; os } \\
\text { Destacamentos que estão nos Fortes nem são a sua } \\
\text { competente força, nem se exercitão de manejo da peça, nem } \\
\text { tem tudi athé hoje outra arma além da baioneta; e alguns } \\
\text { indivíduos dos Fortes para fora da Villa, dormem na mesma, } \\
\text { e de noite não há vigilância no da Villa, ignorando-se que nos } \\
\text { outros se passa; alem disto o Snr. Major Commandante } \\
\text { enfermo e de cama julgando de sua honra não passar o } \\
\text { commando nas actuais circunstâncias, e não podendo pelo } \\
\text { seu impedimento fazer, o que era de esperar da actividade } \\
\text { que mostra seo estado de saúde, temos accordado convocar } \\
\text { hum Conselho Geral de Segurança e Defeza o qual faremos, } \\
\text { sendo da approvação de Vossa Senhoria de quem } \\
\text { esperamos a sua deliberação (...)". }\end{array}$ \\
\hline
\end{tabular}




\begin{tabular}{|c|c|}
\hline $\begin{array}{l}\text { Registo da } \\
\text { resposta do } \\
\text { Offício. } \\
\text { 30/11/1826 }\end{array}$ & $\begin{array}{l}\text { "Acuso a recepção do seu offício, e d’elle fico inteirado e com } \\
\text { bastante dissabor por ver a relaxariação, e desleixo em que } \\
\text { está a defesa desse tão importante porto. Agradeço a V. } \\
\text { Mces. A deliberação, que pertendião tomar sobre esse } \\
\text { objecto; contudo eu já me exponho a todo risco de partir para } \\
\text { essa Villa, e então de acordo com V. Mercês daremos todas } \\
\text { as aquellas providencias que o cazo exige, e que por a bem } \\
\text { do soccego desses habitantes (...). Quartel General do } \\
\text { Governo Militar na Villa da Ilha Grande (...) Manoel Joaquim } \\
\text { Pereira da Silva=Governador Militar. }\end{array}$ \\
\hline $\begin{array}{l}\text { REGISTRO DO } \\
\text { Edital. (...) } \\
\text { Senado da } \\
\text { Camara d'esta } \\
\text { Villa de Nossa } \\
\text { Senhora dos } \\
\text { Remédios de } \\
\text { Paraty. } \\
\text { 30/11/1826 }\end{array}$ & $\begin{array}{l}\text { “(...). Fazemos saber aos moradores d'esta Villa que tendo- } \\
\text { se por Ordem do Ilustríssimo Snr. Governador Militar, em } \\
\text { cumprimento de Determinações de Sua Magestade Imperial, } \\
\text { tomando medidas de precaução a fim de prevenir e sustar } \\
\text { qualquer tentativa que nas Costas do Império quizesse fazer } \\
\text { o inimigo, que se suppunha aproximar-se a ella em forma de } \\
\text { esquadra regular e que tem o feito infestando-as com } \\
\text { destructiva pirataria e Corso (...) Esta Camara tomando } \\
\text { também as medidas que Ihe cumpre em circunstancias taes } \\
\text { designa para a reunião do povo não combatente no cazo de } \\
\text { ser insultada a Villa, a caza de campo do Snr. Capitão } \\
\text { Manoel Antonio Vasco da Gama, aonde se achará pessoas } \\
\text { de reconhecida probidade, e Officiaes de Confiança com } \\
\text { sufficiente escolta para vigarem e zelarem o decoro das } \\
\text { Famílias; guardarem e acutelarem o seu respectivo preciozo } \\
\text { e dirigirem, sendo preciza a retirada em boa ordem, que pelo } \\
\text { rio Bananal em Canoas, que delle fará logo concorrer este } \\
\text { Concelho, e para procurarem a fora da Fazenda do Snr. } \\
\text { Capitão Manoel Cardozo Borba, de onde há de haver o } \\
\text { precizo deposito de mantimentos, as demais acommodações } \\
\text { que forem necessárias (...)". }\end{array}$ \\
\hline $\begin{array}{l}\text { Registro de dois } \\
\text { Officios do } \\
\text { Governador } \\
\text { Militar. } \\
30 / 11 / 1826\end{array}$ & $\begin{array}{l}\text { "Acuso a recepção dos seus dois Officios, em data de hoje, } \\
\text { pelo que diz a nomeação das pessoas fidedignas para } \\
\text { receberam as famílias, e preciosidade d'esta Villa a recahir } \\
\text { no Sargento mor Manoel Gomes Araújo, o Capitão José Luis } \\
\text { Campos Amaral e o Capitão Manoel Joaquim Pereira da } \\
\text { Cruz, acho athé ser uma nomeação mui digna de louvor pela } \\
\text { conhecida probidade, de que são ornados. Talvez minha } \\
\text { demora nesta Villa não seja tempo sufficiente para eu } \\
\text { responder a Vossas Mercês a decizão da mesma, com tudo } \\
\text { deixo ordem ao Sargento mor Commandante do Districto, na } \\
\text { minha auzencia, para Ihes fazer prompta remessa da meam } \\
\text { deliberação d'aquelles senhores. Pleo que diz da escolta } \\
\text { para proteger a retirada das famílias, e precioso e exigidas } \\
\text { em seu citado Officio, muito estimarei não só este } \\
\text { desempenho, como Ihe cumpre nesta perte, como tudo o } \\
\text { mais que fica á sua responsabilidade. Quartel do Governo } \\
\text { Militar na Villa de Paraty (...) Manoel Joaquim Pereira da } \\
\text { Silva, Governador Militar". }\end{array}$ \\
\hline Registro de & "Não me sendo possível por mais tempo fixar (...) rezidencia \\
\hline
\end{tabular}




\begin{tabular}{|c|c|}
\hline $\begin{array}{l}\text { Officio do } \\
\text { Governador } \\
\text { Militar. } \\
\text { 30/11/1826 }\end{array}$ & $\begin{array}{l}\text { nesta Villa como desejava, pelas circunstancias actuaes } \\
\text { assim o permitirem, passo portanto a partir para a Villa da Ilha } \\
\text { Grande, desde como centro do meu Commando, em geral } \\
\text { deva fazer a minha rezidencia. Neste pequeno espaço de } \\
\text { tempo dei aquellas providencias, que me parecerão mais } \\
\text { precizas, a fim de que se consiga algum melhoramento na } \\
\text { importante defeza d'esta Villa. O estabelecimetno de signaes, } \\
\text { de que V. Mces. tão benignamente se prestarão com as } \\
\text { despezas e para as Bandeiras, devera desde hoje, por-se em } \\
\text { pratica desde a Ilha do Mantimento athé esta Villa. Ordenei o } \\
\text { augmento de mais huma peça no Forte da Tapera, assim } \\
\text { como pertendo o estabelecimento de hua Cortina na Ponta } \\
\text { Grossa, donde se possão montar duas, ou três Peças. Este } \\
\text { ponto he considerado como hum dos mais importantes, e por } \\
\text { isso bem applicado huma tal obra, não só pela proteção que } \\
\text { vai prestar as Fazendas athé a Ilha do Algudão, como por } \\
\text { interter alli o inimigo, athé que a Villa e mais pontos tomem as } \\
\text { medidas de defeza (...). A minha estada na Ilha Grande com } \\
\text { tudo não me impossibilita de vir a esta Villa todas as vezes } \\
\text { que Vossas Mercês julgarem ser precizas, pois que assim } \\
\text { não só exige o bom do Serviço como a boa armonia que athé } \\
\text { aqui temos praticado. (...) Quartel General do Governo Militar } \\
\text { na Villa de Paraty. (...) Manoel Joaquim Pereira da Silva, } \\
\text { Governador Militar (...). }\end{array}$ \\
\hline $\begin{array}{l}\text { Registro do } \\
\text { Officio do } \\
\text { Governador } \\
\text { Militar. } \\
\text { 01/12/1826 }\end{array}$ & $\begin{array}{l}\text { "Em conseqüência do Officio que acabo de receber do } \\
\text { Tentente Commandante do Destacamento da llha das } \\
\text { Bexigas, da necessidade que tem huma canoa para os } \\
\text { serviço daquelle Destacamento visto o augmento de praças a } \\
\text { que foi elevado, e a que actualmente existe, acha-se mui } \\
\text { arruinada: rogo portanto a Vossa Mercês, que em atenção ao } \\
\text { expendido, se fassão prestarem durante tão somente em } \\
\text { maior augmento da praça, (...) huma canoa de maior lote } \\
\text { segundo a força do mesmo Destacamento e destinarem hua } \\
\text { menor para ficar existindo. Sim como de ordenar providencias } \\
\text { de transporte para os Praças, que se achão destinados a } \\
\text { trabalhar na nova fortificação na ponta grossa, cujo serviço } \\
\text { deverá principiar no dia segunda-feira, quatro do corrente (...) } \\
\text { Manoel Joaquim Pereira da Silva" }\end{array}$ \\
\hline $\begin{array}{l}\text { Offício de } \\
\text { Anacleto José de } \\
\text { Sousa Castro ao } \\
\text { Presidente da } \\
\text { Câmara da Villa } \\
\text { de Nossa } \\
\text { Senhora dos } \\
\text { Remédios de } \\
\text { Paraty. } \\
\text { 02/12/1826 }\end{array}$ & $\begin{array}{l}\text { "Tendo de se construir, como de effeito se vai dar principio no } \\
\text { dia segunda-feira quatro do corrente mez, a hum Forte no } \\
\text { lugar Ponta grossa, Districto d'estta Villa por ordem do } \\
\text { llustríssimo Senhor Brigadeiro Governador Militar da mesma } \\
\text { Manoel Joaquim Pereira da Silva, hoje me foi requizitada pelo } \\
\text { Tentente Marcellino de Lima Rego, encarregado d'aquelle } \\
\text { trabalho, huma canoa para a condução da Tropa, e mais } \\
\text { Operários para o ditto effeito, a qual deverá estar prompta no } \\
\text { dia quatro d'este mez, pela madrugada e sendo lhe a factura } \\
\text { por se fazer muito necessária para o transporte da Tropa alli } \\
\text { destacada (...)". }\end{array}$ \\
\hline Corr & \\
\hline
\end{tabular}




\begin{tabular}{|c|c|}
\hline $\begin{array}{l}\text { entre Governo } \\
\text { Imperial e } \\
\text { Governador } \\
\text { Militar da Ilha } \\
\text { Grande. } \\
\text { 28/09/1827 }\end{array}$ & $\begin{array}{l}\text { entrou, vindo do Rio de Janeiro e aqui se acha fundeada (ao } \\
\text { amanhecer do dia de hoje) a lancha Espírito Santo, de } \\
\text { Mangaratiba; (...) relata o Mestre que foi roubada no dia } 17 \text {, } \\
\text { na altura de Guaratiba, por uma escuna, tendo já antes disso } \\
\text { a dita escuna roubado ai o barco Americano e a lancha } \\
\text { Marambaia, os quais pretendem ir para a Corte e o Mestre da } \\
\text { Marambaia e sua mulher com mais dois marinheiros que aqui } \\
\text { se acham esperando transporte para suas casas. Logo que } \\
\text { amanheceu o dia participei este conhecimento ao } \\
\text { Comandante do brigue Pampeiro, (...). Francisco de Paula } \\
\text { Carvalho. } 2^{\circ} \text { Tenente". }\end{array}$ \\
\hline $\begin{array}{l}\text { Correspondência } \\
\text { entre Governo } \\
\text { Imperial e } \\
\text { Governador } \\
\text { Militar da Ilha } \\
\text { Grande. } \\
\text { 29/09/1827 }\end{array}$ & $\begin{array}{l}\text { "Ilmo e Exmo. Sr., Agora pela uma hora da tarde, deu fundo } \\
\text { no porto desta vila o Brigue Pampeiro, vindo não só a } \\
\text { proteger o Brigue Atrevido como outras embarcações que } \\
\text { aqui se acham, ao mesmo tempo por lhe constar uns dos } \\
\text { Mestres das sumacas apresadas, que andavam numa } \\
\text { Escuna reunidos para aprisionarem, em conseqüência dessa } \\
\text { notícia de se dividirem as forças. Neste mesma data remeto } \\
\text { por cópia ofício que me dirigiu o } 2^{\circ} \text { Tenente de artilharia de } \\
\text { linha, que se acha destacado nas Palmas, o que Vossa Exa. } \\
\text { Tudo fará para subir a Augusta presença de sua Majestade } \\
\text { (...), para determinar o que for de sua Imperial vontade (...). } \\
\text { Manoel Joaquim Pereira da Silva. Governador Militar". }\end{array}$ \\
\hline $\begin{array}{l}\text { Correspondência } \\
\text { entre Governo } \\
\text { Imperial e } \\
\text { Governador } \\
\text { Militar da Ilha } \\
\text { Grande. } \\
01 / 10 / 1827\end{array}$ & $\begin{array}{l}\text { "Hoje, pelas } 10 \text { horas do dia, deu-me parte o Sargento-Mor } \\
\text { reformado Manoel Jordão da Silva Vargas que mora na Ilha } \\
\text { Grande de Fora, que um seu agregado Ihe dissera ter visto } \\
\text { ontem os três corsários ao mar da Ilha do Grego. Como o } \\
\text { brigue Pampeiro se tinha feito de vela em conseqüência de } \\
\text { um ofício que fiz ao seu Comandante ter entrado neste porto } \\
\text { uma escuna, na vinda do Rio de Janeiro em dois dias e não } \\
\text { dar-me notícias alguma dos corsários. Mandei imediatamente } \\
\text { que me parecia acertado, em conseqüência daquela notícia, } \\
\text { dar fundo e mandar observar um seu Oficial aquele porto: } \\
\text { Assim o fez e logo mandou um Segundo Tenente nessa } \\
\text { diligência, o qual voltou muito breve por encontrar um barco } \\
\text { que vinha arribado fugindo dos mesmos corsários que os } \\
\text { tinha avistado ontem, } 30 \text { de setembro. (...) Manoel Joaquim } \\
\text { Pereira da Silva. Governador Militar". }\end{array}$ \\
\hline $\begin{array}{l}\text { Resposta ao } \\
\text { Offício .... } \\
19 / 06 / 1833\end{array}$ & $\begin{array}{l}\text { "Em resposta ao Officio ...em q' requisita hum Official de } \\
\text { Guarda Nacional, para Inventariar, e por em cautela os } \\
\text { objectos da Fazenda Nacional q'se achão no Forte Defensor, } \\
\text { em conseqüência do acordo q' tomára a Câmara Municipal } \\
\text { desta Villa pela morte do Commandante do referido Forte (...) } \\
\text { Em virtude do Officio que me foi dirigido (...) advertindo } \\
\text { porem, q'alguns barris, em q'existe a pólvora, estão em máo } \\
\text { estado por o cupido os ter dannificado. A chave da Caza de } \\
\text { Pólvora existe em meo poder, faço mais sciente a V. S. para } \\
\text { sua inteligência q'tdos os mais pretechos de Guerra e } \\
\text { ferragens de carretas arruinadas, fica tudo na Salla do }\end{array}$ \\
\hline
\end{tabular}




\begin{tabular}{|c|c|}
\hline & $\begin{array}{l}\text { Quartel entregue ao Sargento do Destacamento (...) Manoel } \\
\text { José da Silva, Major Commandante (...)". }\end{array}$ \\
\hline $\begin{array}{l}\text { Câmara } \\
\text { Municipal de } \\
\text { Angra dos Reis } \\
\text { ao Vice } \\
\text { Presidente do } \\
\text { Rio de Janeiro. } \\
\text { 06/04/1838 }\end{array}$ & $\begin{array}{l}\text { "A Câmara Municipal desta Cidade reconhecendo continuar a } \\
\text { necessidade de se manterem alguas peças do Forte do } \\
\text { Carmo, a respeito do que já em } 23 \text { de janeiro e } 6 \text { de outubro } \\
\text { do anno (...) a Vossa Excelência desconhecendo as cauzas } \\
\text { de não ter sido attendida, leva novamente ao conhecimento } \\
\text { de Vossa Excelência semelhante necessidade para que se } \\
\text { sirva reclamar da autoridade competente as providências } \\
\text { convenientes (..)". }\end{array}$ \\
\hline $\begin{array}{l}\text { Câmara } \\
\text { Municipal de } \\
\text { Angra dos Reis } \\
\text { ao Vice } \\
\text { Presidente do } \\
\text { Rio de Janeiro. } \\
27 / 06 / 1838\end{array}$ & $\begin{array}{l}\text { "Convindo o quanto antes dar-se princípio ao muro da Praia } \\
\text { do Carmo, e sendo necessário (...) proceder ao levantamento } \\
\text { da Planta, a Câmara (...) roga a Vossa Excelência se digne a } \\
\text { ordenar ao engenheiro respectivo para com a possível } \\
\text { brevidade vir levantar a ditta planta (...)" }\end{array}$ \\
\hline $\begin{array}{l}\text { Reg. de Officio } \\
\text { que Camara de } \\
\text { Paraty dirigio ao } \\
\text { Governo d'esta } \\
\text { Província, } \\
\text { pedindo } \\
\text { providencias } \\
\text { sobre os reparos } \\
\text { no Forte } \\
\text { Defensor. } \\
\text { 12/08/1850 }\end{array}$ & $\begin{array}{l}\text { "A Camara Municipal d'esta Cidade seintificada dos factos } \\
\text { injustos e abusivos que os Barcos Inglezes, a pretexto de } \\
\text { evitar e reprimir o trafico de escravos, comettem } \\
\text { freqüentemente sobre os navios brasileiros nos mares } \\
\text { territoriaes do Império, do abuso a tal ponto, que chagão a } \\
\text { aprisionar nossos barcos ancorados nos portos e isto com } \\
\text { manifesta violação do Direito das Gentes, animando-se a } \\
\text { praticar similhantes escândalos, que já mais se harmonizão } \\
\text { com a civilisação de que aquella nação parece querer ser o } \\
\text { typo, por que contão com a fraquesa do paiz e o estado de } \\
\text { ruína quase completa, a que estão redusidas quema grande } \\
\text { parte das fortificações de nossa cósta; a Câmara Municipal } \\
\text { d'esta Cidade cuja vida e prosperidade depende de seo } \\
\text { comercio marítimo, receosa de que os Ingleses, levados de } \\
\text { sua hypocrita philantropia, venão dentro deste Porto revistar, } \\
\text { e aprisionar os barcos de commercio licito, que n'elle estejao } \\
\text { ancorados, como tem acontecido em outros lugares, sem que } \\
\text { de terra ou do Forte Defensor se lhe possa obstar, e nem ao } \\
\text { menos proceder como em Paranaguá, a Camara Municipal } \\
\text { dirige-se a V. E. e pede providencias promptas, para que as } \\
\text { fortificações d'este porto sejão postas na razão de } \\
\text { defenderem de qualquer pirataria que por ventura os Ingleses } \\
\text { venhão cometter a tanto mais que elles estão a crusar esta } \\
\text { barra, onde já revistaram um barco (...), as fortificações } \\
\text { d'este porto (...) estão em completo estado de ruína; o Forte } \\
\text { Defensor, que constitui a principal defeza (...) está sem caza } \\
\text { e quartel, (...) porque tanto uma com outra cousa se abateo } \\
\text { com as chuvas havidas ultimamente, as peças quaze todas } \\
\text { estão encravadas e desmontadas, as faxinas arruinadas, não } \\
\text { há armadilha, e nem pólvora alguma (...). E por isso a } \\
\text { Câmara Municipal apressa-se em levar ao conhecimento de } \\
\text { V. E. e respeitosamente solitia providencias promptas contra } \\
\text { semilhante mal (...)". }\end{array}$ \\
\hline
\end{tabular}




\begin{tabular}{|c|c|}
\hline $\begin{array}{l}\text { Câmara } \\
\text { Municipal de } \\
\text { Angra dos Reis } \\
\text { ao Senhor Dr. } \\
\text { Ignácio } \\
\text { Francisco } \\
\text { Silveira da Mota } \\
\text { - Digno } \\
\text { Presidente da } \\
\text { Província do Rio } \\
\text { de Janeiro. } \\
\text { 01/02/1860 }\end{array}$ & $\begin{array}{l}\text { "Vendo a Câmara Municipal de Angra dos Reis que em } \\
\text { conseqüência da Ordem do Governo Imperial vão ter } \\
\text { dezarmadas as fortificações do litoral desta província e } \\
\text { remetido seu material para o Arcenal de Guerra, mas sendo } \\
\text { indispensável para a segurança e defesa desta cidade a } \\
\text { conservação do Forte Actual, embora sem guarnição, porque } \\
\text { a eventualidade de sua guerra marítima pode trazer a } \\
\text { necessidade de novamente guarnecê-lo, senão para repelir } \\
\text { (...) ao menos para impor respeito a qualquer um que tenta } \\
\text { contra essa cidade, a qual por sua posição geographica e sua } \\
\text { importância comercial está constantemente exposta a taes } \\
\text { tentativas, que de certo se realizarão se em taes ocasiões } \\
\text { não houver nesta cidade fortificação que lhe proporciona os } \\
\text { meios de defesa; por isso, vem respeitosamente representar } \\
\text { a Vossa Excelência, pedindo a conservação do Forte Actual } \\
\text { no estado em que se acha, embora sem guarnição, ficando } \\
\text { confiados alguma Authoridade ou pessoa de confiança de } \\
\text { Vossa Excelência, o mesmo forte e os materiais nele } \\
\text { existentes, para servirem quando for conveniente e } \\
\text { necessário (...)". }\end{array}$ \\
\hline $\begin{array}{l}\text { sta à } \\
\text { ra de } \\
\text { dos Reis - } \\
0 \\
\text { sco } \\
\text { a da Mota } \\
\text { lo } \\
\text { lente da } \\
\text { cia do Rio } \\
\text { neiro. }\end{array}$ & $\begin{array}{l}\text { Em suposta ao officio de } 01 \text { do corrente em que a Câmara } \\
\text { unicipal de Angra representa a esta presidência sobre a } \\
\text { ecessidade de conservar se o Forte desta Cidade, embora } \\
\text { em guarnição prevenir de qualquer emergência futura que } \\
\text { ossa comprometter a segurança da mesma cidade (...) } \\
\text { utoridade a guarda do mesmo e a seus materiaes n'ele } \\
\text { kistentes tenho a declarar a Câmara que, providenciando } \\
\text { obre o que pedi, resolvi que fique o destacamento policial } \\
\text { quartelado no dito forte". }\end{array}$ \\
\hline $\begin{array}{l}\text { dirigido ao } \\
\text { de Suruhy } \\
\text { Manoel } \\
\text { 3arros } \\
\text { ca de Brito } \\
\text { ante } \\
\text { cal do } \\
\text { ito }\end{array}$ & $\begin{array}{l}\text { "(...) Cumpre-me informar a Vossa Excelência que as cinco } \\
\text { fortificações do litoral desta província situadas em Macaé, } \\
\text { Cabo Frio, Angra dos Reis, Mangaratiba e Paraty, forão } \\
\text { postas a disposição da Presidência da Província em virtude } \\
\text { dos avizos do mesmo Ministério de } 19 \text { de novembro de } 1859 \text {, } \\
\text { e de } 02 \text { de janeiro deste anno, por cujo motivo achão-se } \\
\text { aquartelados presentemente nessas fortificações } \\
\text { destacamentos policiaes ficando a cargo da administração } \\
\text { provincial todo o material ali existente (...). Deos guarde a } \\
\text { Vossa Excelência". }\end{array}$ \\
\hline
\end{tabular}




\section{Documentos sobre a Ilha Grande e a Vila de Nossa Senhora da Conceição de Angra dos Reis da Ilha Grande}

\begin{tabular}{|c|c|}
\hline $\begin{array}{l}\text { Prática da Arte de } \\
\text { Navegar, de Luiz } \\
\text { Serrão Pimentel. } \\
1673\end{array}$ & $\begin{array}{l}\text { "E por esta barra de Garatuba entram embarcações } \\
\text { pequenas; mas por entre o monte Marambaia, é uma terra } \\
\text { verde, grande (...). Entretanto, ao Norte, ireis por } 15 \text { braças } \\
\text { (...) e surgireis na terra do Oeste, que é a Ilha Grande (...). E } \\
\text { estado no meio da dita Ilha (...) tendes a Ilha da Ipoja (...) e } \\
\text { defronte dela, ao nordeste, está a povoação nova de Angra } \\
\text { dos Reis, ao sul da Ilha Grande". }\end{array}$ \\
\hline $\begin{array}{l}\text { Relation d'um } \\
\text { Voyage...François } \\
\text { Froger. } \\
\text { 29/12/1695 }\end{array}$ & $\begin{array}{l}\text { "Dia } 29 \text { ancoramos às sete da noite, à entrada da Ilha } \\
\text { Grande, (...), no dia } 30 \text { o calor estava insuportável. A tarde } \\
\text { (...) levantamos âncora e navegamos (...) até sua agradável } \\
\text { praia (...). A llha Grande tem cerca de } 18 \text { léguas de } \\
\text { circunferência ; é montanhosa e coberta de uma vegetação } \\
\text { (...) espessa (...). Em terra firme (...) defronte desta enseada } \\
\text { existe uma importante vila portuguesa de quatrocentos a } \\
\text { quinhentos habitantes, com dois conventos um de carmelitas } \\
\text { e outro de franciscanos. O governo do Rio de Janeiro proibiu } \\
\text { os habitantes de negociarem conosco: mas eles não fizeram } \\
\text { caso e nos venderam tudo de que precisávamos; têm suas } \\
\text { casas sobre morros e manifestam como os paulistas uma } \\
\text { grande ânsia de liberdade". }\end{array}$ \\
\hline $\begin{array}{l}\text { Despacho de } \\
\text { José Bonifácio de } \\
\text { Andrada e Silva. } \\
13 / 02 / 1823\end{array}$ & $\begin{array}{l}\text { "Sendo conveniente abreviar as contíguas demandas que se } \\
\text { levantam nas terras da Ilha Grande sobre as demarcações } \\
\text { de terras, com grande prejuízo dos possuidores delas, } \\
\text { manda Sua Majestade o Imperador, pela Secretária dos } \\
\text { Negócios do Império, que o Juiz de Fora daquele termo } \\
\text { obrigue as pessoas que têm sesmarias apresentar seus } \\
\text { títulos em juízo, para à vista desses se proceder nova } \\
\text { demarcação dos respectivos termos, e evitar-se desse modo } \\
\text { a multiplicação de pleitos e os males que dele resultarem". }\end{array}$ \\
\hline $\begin{array}{l}\text { Excursão } \\
\text { Ministerial, Raul } \\
\text { Pompéia, Gazeta } \\
\text { da Tarde. } \\
15 \text { a 22/04/1886 }\end{array}$ & $\begin{array}{l}\text { "(...) Angra dos Reis é uma pequena cidade, de velha } \\
\text { construção portuguesa, como que se vê em parte do Rio de } \\
\text { Janeiro, ruas estreitas e prédios de sacada (...)". }\end{array}$ \\
\hline
\end{tabular}




\section{Documentos sobre a Vila de Santos e São Vicente}

\begin{tabular}{|c|c|}
\hline $\begin{array}{l}\text { Registro da } \\
\text { Carta de Sua } \\
\text { Magestade ao } \\
\text { governador desta } \\
\text { praça sobre o } \\
\text { que manda lhe } \\
\text { acuda com todo } \\
\text { o necessário } \\
\text { para a defença } \\
\text { do inimigo. } \\
24 / 04 / 1690\end{array}$ & $\begin{array}{l}\text { "João Furtado (...), eu El Rey vos envio muito saudar, Diogo } \\
\text { (...) de Araújo, morador da Villa de Santos da Capitania de } \\
\text { São Vicente e procurador da Coroa fazenda e fisco me deu } \\
\text { conta em carta de } 3 \text { de mayo deste anno da entrado do } \\
\text { inimigo Pirata tinha feito naquelas villas e ilhas destruindo } \\
\text { tudo, destruindo aos moradores (...) no caso que estas } \\
\text { capitanias se virem em algum apertto (...) Ihes acudais com } \\
\text { tudo o que lhe for necessário (...)". }\end{array}$ \\
\hline $\begin{array}{l}\text { Registro da } \\
\text { Carta de Sua } \\
\text { Magestade } \\
\text { escrita ao } \\
\text { governador desta } \\
\text { Capitania Artur } \\
\text { de Sá Meneses } \\
\text { sobre a forma } \\
\text { em que se deve } \\
\text { socorrer alguma } \\
\text { embarcação } \\
\text { vinda de Santos. } \\
\text { 20/01/1704 }\end{array}$ & $\begin{array}{l}\text { "Artur de Sá e Meneses, eu El Rei vos envio muito saudar, } \\
\text { havendo visto o que representastes sobre a forma em que } \\
\text { deveis socorrer alguma embarcação que vindo de Santos se } \\
\text { encontre com algum navio de Piratas (...). Me pareceu } \\
\text { ordenaivos que na necessidade precisais socorrais as nossas } \\
\text { embarcações que se acharem em perigo por algum navio } \\
\text { mercante ou por algum dos comboios da Junta sendo em } \\
\text { tempo que não prejudique a partida da frota (...)". }\end{array}$ \\
\hline $\begin{array}{l}\text { ** Sobre se } \\
\text { haverem de } \\
\text { remeter dinheiro } \\
\text { para a praça de } \\
\text { Santos } \\
20 / 09 / 1725\end{array}$ & $\begin{array}{l}\text { Governador de São Paulo Rodrigo César de Menezes } \\
\text { mandou carta ao rei por saber que as fortalezas da vila de } \\
\text { Santos e a guarnição daquele presídio necessitavam de } \\
\text { reformas..Fortaleza da Barra necessitava de um armazém } \\
\text { para colocar pólvora...é preciso adiantar obras e evitar a ruína } \\
\text { de outras fortalezas...passar o dinheiro vencido da } \\
\text { consignação de Santos e que se continue a remeter sem } \\
\text { alteração por ser preciso o dinheiro para o repara das } \\
\text { fortificações. }\end{array}$ \\
\hline
\end{tabular}




\section{Documentos sobre Caminhos}

\begin{tabular}{|c|c|}
\hline $\begin{array}{l}\text { Representação } \\
\text { do Conselho } \\
\text { Ultramarino a } \\
\text { El-Rei. } \\
\text { 08/12/1701 }\end{array}$ & $\begin{array}{l}\text { "Os caminhos que levam, no Brasil, às Minas, porque tantos } \\
\text { quanto mais forem os caminhos mais descaminhos haverá, não } \\
\text { só dos quintos mas mesmo do ouro, e também sendo por } \\
\text { alguma não invadidas as Minas serão necessários socorros de } \\
\text { muitas gentes". }\end{array}$ \\
\hline $\begin{array}{l}\text { Regimento das } \\
\text { Minas - Arthur } \\
\text { Sá de } \\
\text { Meneses. } \\
1702\end{array}$ & $\begin{array}{l}\text { "Nenhuma pessoa da Bahia podia levas às Minas, pelo } \\
\text { caminho do sertão, outa cousa senão gado, e que os que } \\
\text { pretendessem transportar qualquer mercadoria para as } \\
\text { mesmas, deviam navegar para o Rio de Janeiro, tomando daí o } \\
\text { rumo de Paraty (...)". }\end{array}$ \\
\hline $\begin{array}{l}\text { Resposta de } \\
\text { Luis Vahia } \\
\text { Monteiro, } \\
\text { governador do } \\
\text { Rio de Janeiro. } \\
\text { 05/07/1726 }\end{array}$ & $\begin{array}{l}\text { Em observância desta ordem de Vossa Majestade fiz dar uma } \\
\text { busca geral nesta cidade, metendo ao mesmo tempo guardas a } \\
\text { todas as portas de mineiros, ourives e mais pessoas } \\
\text { suspeitosas para que não deixassem entrar gente nas casas, } \\
\text { nem sair, nem bulir dentro delas coisa alguma (...) e no mesmo } \\
\text { tempo mandei um Capitão de confiança pela estrada das minas } \\
\text { a examinar de repente sobre a mesma marcha todos quantos } \\
\text { passageiros encontrou fazendo, examinar ao mesmo tempo } \\
\text { neste Porto todas as embarcações que vinham de Paraty, e } \\
\text { mais vilas do Sul (...) e a mesma providencia tenho dado no } \\
\text { registro de Paraty, cuja vila tornou a jurisdição deste Governo } \\
\text { por resolução de Vossa Majestade de } 16 \text { de janeiro do } \\
\text { presente ano, mas o comércio que deste estado se cultiva para } \\
\text { a costa da mina extravia muito ouro que recolhe os holandeses } \\
\text { no Castelo de São Jorge, os quais entretém correspondências } \\
\text { com os mercadores da Bahia (...) não me parece forçoso que } \\
\text { haja guardas para resistir aos mineiros quando entram naquela } \\
\text { cidade e seus contornos porque na saída das minas é } \\
\text { inevitável o descaminho pela muita largueza e várias veredas e } \\
\text { estradas por donde se sai delas (...). }\end{array}$ \\
\hline $\begin{array}{l}\text { Sobre se dar } \\
\text { toda ajuda } \\
\text { necessária } \\
\text { para abertura } \\
\text { do caminho de } \\
\text { São Paulo para } \\
\text { esta cidade. } \\
\text { 14/10/1726 }\end{array}$ & $\begin{array}{l}\text { "Dom João por graças de Deus Rei de Portugal (...). Faço } \\
\text { saber a vós Luis Vahia Monteiro (...) que vendo-se o que } \\
\text { respondeu o Governador da Capitania de São Paulo, Rodrigo } \\
\text { César de Menezes, em carta de } 27 \text { de Maio deste ano a ordem } \\
\text { que Ihe foi para dar conta do que tinha resultado da abertura do } \\
\text { caminho daquela capitania para esta capitania, que tinha } \\
\text { ajustado se fizesse representando-me haver posto todo o } \\
\text { cuidado para se concluir o dito caminho havendo já feito picada } \\
\text { em direitura os homens que foram encarregados daquela } \\
\text { diligência e que estaria já de todo aberto muito adiantado se } \\
\text { lhe não embaraçassem os afetados requerimentos que alguns } \\
\text { dos moradores de Paraty fizeram atendendo-se as suas } \\
\text { conveniências, e como aquela vila é subordinada a este } \\
\text { governo. Me pareceu ordenaivos concorrais com tudo que } \\
\text { puderes para que se consiga obra tão útil a minha real fazenda, } \\
\text { e para que se não dilate e possa ter efeito darei toda ajuda } \\
\text { necessária". }\end{array}$ \\
\hline
\end{tabular}




\begin{tabular}{|c|c|}
\hline $\begin{array}{l}\text { Sobre a } \\
\text { arrecadação } \\
\text { dos dízimos. } \\
\text { 07/11/1726 }\end{array}$ & $\begin{array}{l}\text { "Na jornada que fiz até a Vila de Paraty entre as muitas, e } \\
\text { grossas terras que achei incultas vi também muitas cultivadas, } \\
\text { e bem povoadas as que correm desta cidade para o sul até } \\
\text { Curitiba, em espaço de } 14 \text { léguas, sendo incomparavelmente } \\
\text { mais povoadas e cultivadas todas as que ficam na praia, e a } \\
\text { vista do mar desta baía da barra para dentro que tem muitos } \\
\text { rios a margem dos quais tudo está habitado, e da mesma sorte } \\
\text { é tudo para o sul até Cabo Frio, e finalmente nos campos de } \\
\text { Goytacazes, e querendo eu na volta desta jornada examinar a } \\
\text { importância deste rendimento do primeiro quartel dos contratos, } \\
\text { fiz pela causa referida particular reflexão no pouco que rendem } \\
\text { a V. M. os dízimos desta Capitania (...) o tráfico e o comércio } \\
\text { que se praticam neste porto (...)" }\end{array}$ \\
\hline $\begin{array}{l}\text { Resposta de } \\
\text { Luis Vahia } \\
\text { Monteiro, } \\
\text { governador do } \\
\text { Rio de Janeiro. } \\
06 / 07 / 1727\end{array}$ & $\begin{array}{l}\text { Um mês depois que tomei posse deste governo me fizeram os } \\
\text { moradores da vila de Guaratinguetá do distrito de São Paulo } \\
\text { (com os quais aquele governo tinha ajustado a abertura deste } \\
\text { caminho) petição para lhe assegurar as sesmarias das terras } \\
\text { por onde o dito caminho havia de passar no meu distrito e } \\
\text { olhando eu para outras promessas que se tem feito a sua } \\
\text { Majestade que se não achavam executadas e juntamente para } \\
\text { me assegurar a quem pertenciam as ditas sesmarias lhe pus o } \\
\text { despacho ao que de nenhuma sorte quiseram satisfazer (...) } \\
\text { depois do que me fizeram os moradores da Vila de Angra dos } \\
\text { Reis e Paraty requerimento para embaraçar o caminho com o } \\
\text { pretexto de que se haviam de extinguir as vilas por falta de } \\
\text { comunicação e que era mais conveniente fazer o caminho } \\
\text { pelas mesmas vilas, (...) nas praias, e este prometido vem pelo } \\
\text { sertão, e suposto que Ihe não respondi a estas circunstâncias } \\
\text { Ihes ordenei prendessem os de Guaratinguetá se entrassem no } \\
\text { meu distrito sem apresentarem ordem minha depois do que me } \\
\text { escreveu Rodrigo César sobre o que Ihe respondi o referido, e } \\
\text { que se os homens queriam fazer o caminho viesse ajustar } \\
\text { comigo, o que nunca quiseram fazer usando somente de várias } \\
\text { cartas pretendendo fazer o caminho somente até a altura de } \\
\text { Paraty (...) e dou ordem para poderem abrir e se Ihe dar toda } \\
\text { ajuda e favor, mas estou certo que este caminho se tiver efeito } \\
\text { prejudicará muito na arrecadação dos quintos principalmente } \\
\text { nas Minas Gerais, porque pela sua picada se tem já feito } \\
\text { algumas fraudes, porém, o certo é, que ele nunca terá efeito } \\
\text { porque suposto o ponham corrente não é possível o habitarem } \\
\text { porque a facilidade de levarem as fazendas daqui a Santos por } \\
\text { mar com pouca despesa precisamente há de evitar a } \\
\text { freqüência do caminho novo das minas gerais que muita gente } \\
\text { deixa de ir por ele que embarca daqui das fazendas até Paraty, } \\
\text { de onde tem menos transito por terra para as minas e se eu } \\
\text { não achasse alguma dificuldade da Ilha até Paraty por uma } \\
\text { grande serra, este era o caminho mais proporcionado, visto que } \\
\text { já se vai por terra até Angra dos Reis, ou Ilha Grande, e de } \\
\text { Paraty para São Paulo sempre houve um caminho por terra, } \\
\text { mas pouca gente o que freqüentar (...).. }\end{array}$ \\
\hline
\end{tabular}




\section{Documentos sobre o Forte do Leme, Ponta Leste, Angra dos Reis}

\begin{tabular}{|c|c|}
\hline $\begin{array}{l}\text { Fé de Offício do } \\
\text { Senhor Capitão } \\
\text { da Arma de } \\
\text { Engenharia } \\
\text { Rosalvo Mariano } \\
\text { Silva. } \\
\text { 03/1909 }\end{array}$ & $\begin{array}{l}\text { "(...) por aviso de primeiro, foi dispensado do cargo de auxiliar } \\
\text { da Comissão Construtora da Fábrica de Pólvora Sem } \\
\text { Fumaça, sendo pelo mesmo aviso, nomeado a servir na } \\
\text { comissão encarregada da construção da Bateria do Leme } \\
\text { (...)". }\end{array}$ \\
\hline $\begin{array}{l}\text { Noticiário - } \\
\text { Ponta do Leme. } \\
\text { 14/06/1909 }\end{array}$ & $\begin{array}{l}\text { "No dia } 9 \text { do corrente, à tarde, ancoraram em nosso porto, os } \\
\text { rebocadores Marechal Vasques e Tuyuty, trazendo à reboque } \\
\text { um grande batelão carregado de materiaes; destinados ao } \\
\text { serviço de construcção da fortaleza da Ponta do Leme, neste } \\
\text { município (...). O Dr. Rosalvo está encarregado de dirigir as } \\
\text { obras de construcção da referida fortaleza, que já começaram } \\
\text { (...)". }\end{array}$ \\
\hline $\begin{array}{l}\text { Comissão Militar. } \\
11 / 07 / 1909\end{array}$ & $\begin{array}{l}\text { "No rebocador Marechal Vasques, entraram no dia } 06 \text { em } \\
\text { nosso porto, chegaram do Rio de Janeiro (...), os Exms. Srs. } \\
\text { General Dr. Modestino Augusto de Assis Martins, chefe da } \\
\text { Engenharia Militar do Brazil, o capitão de mar e guerra } \\
\text { Spinola, o capitão tenente Agenor deCarvalho e os coronéis } \\
\text { de engenheiros Drs. Bevilacqua e Prado, que vieram } \\
\text { examinar as fortificações projectadas no golpho da Ilha } \\
\text { Grande. Acompanhou a illustre comissão até a ponta do } \\
\text { Leme (...) o senhor coronel Honório Lima (...)". }\end{array}$ \\
\hline $\begin{array}{l}\text { A questão do } \\
\text { Arsenal - Sobre } \\
\text { a Ilha Grande. } \\
12 / 12 / 1909\end{array}$ & $\begin{array}{l}\text { "(...) a sua defeza é um complemento da do Rio de Janeiro e } \\
\text { tão importante quanto a defeza da própria barra do Rio. E } \\
\text { para pôr esta vasta baia ao abrigo de um golpe de mão do } \\
\text { inimigo, o melhor meio é dotal-a de todos os elementos para } \\
\text { que a esquadra ahi se mantenha e faça della sua base de } \\
\text { operações". }\end{array}$ \\
\hline $\begin{array}{l}\text { Fé de Offício do } \\
\text { Sr. Capitão da } \\
\text { Arma de Eng. } \\
\text { Rosalvo Mariano } \\
\text { Silva. } \\
02 / 1910\end{array}$ & $\begin{array}{l}\text { "(...) por portaria de vinte e três foi exonerado do cargo de } \\
\text { auxiliar da } 2^{a} \text { secção da Divisão de Engenheiros deste } \\
\text { Departamento, continuando como encarregado da construção } \\
\text { da Bateria do Leme, em Angra dos Reis (...)". }\end{array}$ \\
\hline $\begin{array}{l}\text { Fé de Offício Sr. } \\
\text {. Rosalvo M. } \\
\text { Silva. } \\
05 / 1911\end{array}$ & $\begin{array}{l}\text { "(...) por aviso de dezesseis, foi mandado fiscalizar as obras } \\
\text { que o Ministro da Marinha está fazendo em Angra dos Reis } \\
(\ldots) \text { ". }\end{array}$ \\
\hline $\begin{array}{l}\text { A defesa de } \\
\text { nosso litoral. } \\
25 / 06 / 1911\end{array}$ & $\begin{array}{l}\text { "(...) Quando Ministro da Guerra o actual chefe da Nação, } \\
\text { espossando, depois de estudos próprios, esse antigo voto, } \\
\text { resolveu fortificar aquella posição, fazendo construir as obras } \\
\text { de defesa da Ponta do Leme, que são as avançadas do } \\
\text { systema, e tendem, se prosseguidas no seu conjunto, a crear }\end{array}$ \\
\hline
\end{tabular}




\begin{tabular}{|c|c|}
\hline & $\begin{array}{l}\text { uma verdadeira e inexpugnável base naval no golfo daquella } \\
\text { ilha. Nós vamos além neste capítulo: com o laudo do } \\
\text { inolvidável Calheiros da Graça, do Almirante Noronha, e } \\
\text { muitos outros, fazemos votos para que i futuro da llha Grande } \\
\text { se transforme n'um grande porto militar (como se dispunha a } \\
\text { fazel-o a casa Armstrong, no tempo do Presidente Rodrigues } \\
\text { Alves), construindo-se ali o novo arsenal da Marinha (...). O } \\
\text { artilhamento da Ponta do Leme, o prolongamento da estrada } \\
\text { de ferro a Itacurussá e a Angra e a criação da grande escola } \\
\text { de Grumetes alli, são obras de vasto alcance, preparatórias } \\
\text { (...) à realização do velho sonho - a base naval do Golpho da } \\
\text { llha Grande. A invasão pelas forças de Duclerc (...) } \\
\text { mostraram como é fácil qualquer opoeração desembarque e } \\
\text { ataque por terra ao Rio de Janeiro (...)". }\end{array}$ \\
\hline $\begin{array}{l}\text { Terra e Mar. } \\
\text { 30/07/1911 }\end{array}$ & $\begin{array}{l}\text { "(..) S. Ex. quando Ministro da Guerra, em seu relatório de } \\
1908 \text {, pedindo a construção do ramal férreo em Angra dos } \\
\text { Reis e mandando erguer as primeiras baterias da ponta do } \\
\text { Leme, indicou de modo claro as idéias sobre o assumpto } \\
\text { (...)". }\end{array}$ \\
\hline $\begin{array}{l}\text { Visita } \\
\text { Presidencial: } \\
\text { Escola de } \\
\text { Grumetes - } \\
\text { Forte do Leme- } \\
\text { Marechal } \\
\text { Hermes da } \\
\text { Fonseca. } \\
\text { 29/10/1911 }\end{array}$ & $\begin{array}{l}\text { "Visita ao Forte do Leme: Ante-hontem o senhor Marechal } \\
\text { Hermes (...) fez uma visita ao Forte do Leme, cujas obras de } \\
\text { construção estão sendo excutadas sob a imediata direção do } \\
\text { sr. Capitão de Engenharia do Exército Rosalvo Mariano Silva } \\
\text { (...). S. Ex. percorreu aquella praça de guerra (...). Foram } \\
\text { feitos dois disparos dos seus poderosos canhões (...)". }\end{array}$ \\
\hline $\begin{array}{l}\text { Fé de Offício do } \\
\text { Sr. Cap. da Arma } \\
\text { de Engenharia } \\
\text { Rosalvo Mariano } \\
\text { Silva } \\
02 / 1916\end{array}$ & $\begin{array}{l}\text { "(...) foi dispensado de auxiliar da Comissão de defeza do } \\
\text { littoral do estado do Rio de Janeiro e por ter sido a referida } \\
\text { comissão extincta pelo aviso número um (...). Em virtude do } \\
\text { disposto no alludido aviso foi posto à disposição desta } \\
\text { repartição para ultimar a construção das obras do quartel da } \\
\text { Bateria da Ponta do Leme, em Angra dos Reis (...)". }\end{array}$ \\
\hline
\end{tabular}

